\title{
CHARLAS PROSPECTIVAS
}

CON SUS AUTORES Y ACIORES. CONIRIBUCIÓN A LA HISTORIA DE LA PROSPECTIVA EN MÉXICO

\section{Guillermina Baena Paz \\ Coordinadora}
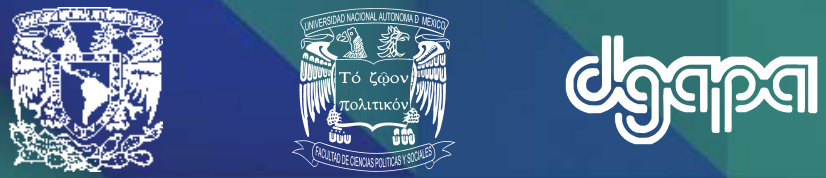


\title{
UNIVERSIDAD NACIONAL AUTÓNOMA DE MÉXICO
}

\author{
Rector $\bullet$ Enrique Luis Graue Wiechers \\ Secretario General • Leonardo Lomelí Vanegas \\ Secretario Administrativo • Leopoldo Silva Gutiérrez \\ Abogada General • Mónica González Contró \\ Director General de Publicaciones y Fomento Editorial • Javier Martínez Ramírez

\section{FACULTAD DE CIENCIAS POLÍTICAS Y SOCIALES} \\ Directora • María Angélica Cuéllar Vázquez \\ Secretaria General • Arturo Chávez López \\ Secretario Administrativo • José Alejandro Santiago Jiménez \\ Jefa del Departamento de Publicaciones • María Eugenia Campos Cázares
}




\section{CHARLAS PROSPECTIVAS}

CON SUS AUTORES Y ACTORES.

CONTRIBUCIÓN A LA HISTORIA DE LA PROSPECTIVA EN MÉXICO

Guillermina Baena Paz

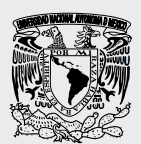

Universidad Nacional

Autónoma de México 
Esta investigación, arbitrada a "doble ciego" por especialistas en la materia, se privilegia con el aval de la Facultad de Ciencias Políticas y Sociales, Universidad Nacional Nacional Autónoma de México.

Charlas Prospectivas. Con sus autores y actores. Contribución a la historia de la Prospectiva en México.

Este libro fue financiado con recursos de la Dirección General de Asuntos del Personal Académico de la Universidad Nacional Autónoma de México, mediante el proyecto "Prospectiva política y social. Materiales didácticos para su apropiación", coordinado por el Dra. Guillermina Baena Paz, como parte del Programa de Apoyo a Proyectos para la Innovación y Mejoramiento de la Enseñanza (PAPIME), PE303815.

Primera edición: 8 de junio, 2016.

D.R. (C) Universidad Nacional Autónoma de México

Ciudad Universitaria, Delegación Coyoacán, C.P. 04510, Ciudad de México.

Facultad de Ciencias Políticas y Sociales, Circuito "Maestro Mario de la Cueva" s/n, Ciudad Universitaria, Delegación Coyoacán, C.P. 04510, Ciudad de México.

ISBN 978-607-02-8126-6

Queda prohibida la reproducción parcial o total, directa o indirecta, del contenido de la presente obra, sin contar previamente con la autorización expresa y por escrito de los editores, en términos de lo así previsto por la Ley Federal del Derecho de Autor y, en su caso, de los tratados internacionales aplicables.

Impreso y hecho en México/Made and printed in Mexico. 
INTRODUCCIÓN $\ldots \ldots \ldots \ldots \ldots \ldots$

PRIMERA PARTE. LOS ORÍGENES

El inicio de la PROSPECTIVA en MÉXICO: AdiP SABAG . . . . . . . . . . . . . 11

La Fundación Javier Barros Sierra: Antonio Alonso Concheiro. . . . . 19

PROSPECTIVA EN MÉXICO Y LATINOAMÉRICA, EDUCACIÓN

Y PROSPECTIVA: AXEL DIDRIKSSON . . . . . . . . . . . . . . . . . . . 4l

LA WFS MÉXICO, el GRUPO CORAZA . . . . . . . . . . . . . . . . . . . . . 59

Y la PROSPECTIVA: Julio Millán Bojalil

SEGUNDA PARTE. VISIONES GENERALES

Prospectiva en México: Manuel Cervera . . . . . . . . . . . . . . . 85

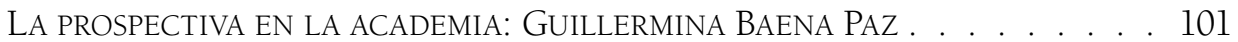

MATRIZ DE PROSPECTIVA ESTRATÉGICA: TOMÁS MiKLOS

Y MARGARITA ARROYO . . . . . . . . . . . . . . . . . . . . . . . 109

Visión CRÍTICA DE la PROSPECTIVA: YURI SERBOlov . . . . . . . . . . . . . 117

PROSPECTIVA EN LA GLOBALIZACIÓN,

Visión HOlística: Sergio Montero OliVARES . . . . . . . . . . . . . 133 
TERCERA PARTE. VISIONES ESPECIALIZADAS

Prospectiva APlicada Al CAMPo: EdMUndo Aguilar . . . . . . . . . . . 141

Prospectiva Científico-TeCNOlÓGicA en MÉXico: . . . . . . . . . . . . . 149

FRANCISCO SORIA VILLEGAS

Prospectiva en administración: Silvestre Méndez Morales. . . . . . . 173

La Consultoría en PRospectiva en MéXico: Moraima Carvajal . . . . . 181

QUIÉNES SON LOS AUTORES Y ACTORES. . . . . . . . . . . . . . . . . . 199 
1 presente libro es una aportación original, y considero muy valiosa, al exponer la variedad de puntos de vista sobre la manera de hacer prospectiva en voz de sus protagonistas quienes han sido actores y autores de la visión de futuro en México.

Se plantea el porqué y el cómo de la teoría y la práctica de la prospectiva y en ese sentido es una recopilación única donde sus protagonistas comparten con su voz y personalidad, así como su propio sentir los retos y oportunidades que han experimentado.

El tono tenía que recupera la fluidez de la charla, que acerca más al público. Las narraciones atractivas, insertas con las anécdotas que atrapan el interés, y que descubren el perfil del prospectivista, a veces con una sola frase, o con toda una historia personal y profesional. Esto es el valor agregado al texto y el interés en recuperarlo cual si fuese una crónica de la historia de la prospectiva porque la prospectiva también tiene su historia. De ahí aprendemos a la vez sobre el contexto social-político y de investigación que da sentido a las decisiones y políticas accionadas con visión de largo plazo.

¿Cómo surgió esta idea?: La Universidad del Externado en Colombia tiene dentro de su Maestría en Prospectiva estratégica la materia de Profundización de la conjetura como complemento a sus estudios los alumnos salen a estudiar un curso afuera de su país. El director de la Maestría, doctor Francisco Mojica nos pidió organizar en México una visita académica de un grupo de alumnos que programamos de julio $28 \mathrm{al} 1^{\circ}$ de agosto 2014, fue así como concebimos la posibilidad de organizar un ciclo de pláticas con los autores y actores de la prospectiva en 
nuestro país como parte de ese curso de Profundización de la Conjetura y como Estudios de caso en México en las instalaciones de las Facultades de Ciencias Políticas y Sociales, en Ingeniería y en Contaduría y Administración en la UNAM. Así como dos visitas a consultorías Coraza y Analítica.

Para nuestra sorpresa, la convocatoria fue muy bien acogida y participaron todos quienes de alguna manera han contribuido con experiencias personales, profesionales, académicas y de consultoría a la construcción de la prospectiva en México. El material surgido era demasiado valioso para quedarse en las aulas. Me di a la tarea de integrar una memoria histórica con todas las participaciones que difícilmente podrían estar de nuevo juntas. Estaban contando una historia que no tenemos y que era muy importante recuperar de manera escrita, con aquél material y con la frescura de la presentación oral.

El lector encontrará en este texto, tres grandes apartados, cuando la prospectiva inicia sus orígenes, posteriormente la visión de la prospectiva desde diferentes ángulos y en la última parte, la manera en que se aplica de forma especializada.

Desde luego nuestro agradecimiento a todos los participantes en aquél evento y a quienes nos ayudaron con parte de la integración de los datos: Mario Ramírez Chávez, Jonathan A. Correa Ortiz y Patricia Baena Paz.

Sin duda el propio texto se constituirá como base de la enseñanza aprendizaje de la prospectiva en aulas y para todos los interesados en el tema en cualquier lugar donde se encuentren. No lo hubiéramos logrado sin el apoyo del PAPIME PE 303815 que vuelve a darnos esta oportunidad única.

DRA. GUILlERMina BAENA PAZ Invierno de 2015 
PRIMERA PARTE

LOS ORÍGENES 


\section{EL INICIO DE LA PROSPECTIVA EN MÉXICO: ADIP SABAG}

ntes que nada agradezco a la Dra. Guillermina Baena Paz, quien ha hecho un trabajo muy grande por la prospectiva en nuestro país, y el esfuerzo de unir a todos los que pensamos en prospectiva.

Estuve en Colombia, aquí es un agradecimiento a los colombianos, me invitaron a un estudio económico. Su trato es sumamente cálido y maravilloso, pero bueno, no perdamos el tiempo, que es muy preciado.

La primera cosa que les quiero platicar de los prospectivistas es el destino de Casandra, es aquél personaje de la mitología griega que le habían dado el don de adivinar el futuro, esa es Casandra, que por cierto mi hija se llama Casandra y está en Ecuador. Entonces, por algunos problemas de los dioses griegos que son muy vengativos, iba a recibir un castigo, le dijeron que no le podían quitar el don de adivinar el futuro porque eso se lo dio el Olimpo, pero la iban a castigar: haciendo que nadie le creyera, entonces ella seguía adivinando el futuro, entraba en un trance, bueno ya se conocen las tragedias griegas, y claro llegaba el destino y se realizaba lo que ella adivinaba.

Yo me he dedicado a la educación y a los medios masivos de comunicación y he tenido la fortuna de participar en los más importantes periódicos: El Universal, Excélsior y El Financiero, donde particularmente con su director, quien ya falleció, publicamos en una época unas proyecciones económicas a corto plazo, no es prospectiva, y, en ese estudio mencionábamos que iba a haber una debacle económica, 100\% de devaluación y otros indicadores. El periódico circula de lunes a viernes como la actividad financiera, y cada día estuvimos publicando una predicción catastrófica. La reacción no se hizo esperar e inmediatamente nos dijeron que cómo era posible que en pleno auge financiero de México estuviéramos hablando ya de devaluación. 
Como nunca contesto a esas preguntas, presionaron al Director del periódico que explicara los argumentos detrás de las predicciones a lo que comenté: No, porque eso ya cuesta honorarios profesionales, porque no les gusta pagar, quieren que uno les dé todo. Entonces le pusimos con todas sus letras: 1994, y esperamos, tiempo al tiempo y llegó el año 1994, los meses de marzo-abril y no pasaba nada, pensé, ahora si quedamos en ridículo y entonces llegó el mes de diciembre, le llamaron diciembre negro, donde hubo más de 100\% de devaluación con lo cual mi conciencia está tranquila. La otra fue que vimos un aumento del desempleo en Estados Unidos, y en esos momentos (julio 2014), la revista Forbes hablaba ya de una crisis peor que la Gran Depresión de 1929, y esto es para los prospectivas, que tengan cuidado, porque somos los primeros en ver las cosas y no planificamos nuestro propio futuro "empiécenle porque no sabemos en qué momento viene el latigazo".

Entonces vimos que ya venía un desempleo terrible para México, publicamos esas ideas, y comenzamos a preparar a la sociedad para advertir, porque de eso se trata la prospectiva, advertimos; y nadie nos creyó, igual que con la devaluación. Me acuerdo muy bien que me invitaron a unas conferencias en la Universidad de Guadalajara; y a la hora de plantearlo al auditorio nadie creyó en el desempleo. Lo único que les dije fue "prepárense y armen su propia empresa porque viene un desempleo terrible", sólo dije, "tiempo al tiempo".

Ahora tenemos una crisis en donde el sistema financiero premia a las empresas que corren a sus trabajadores.

La tercera predicción fue política. La política es la más delicada porque va de por medio su vida, los mata, no nos andamos con juegos y si no los matan, los corren; los censuran; por eso la política es terrible. Y hace muchos años publicamos un estudio muchos años antes, esa ya casi es prospectiva, que iba a haber un atentado en México a un alto funcionario. Los periódicos no se hicieron esperar en su reacción criticando y censurando nuestro estudio, "gatilleros" que manda el gobierno. Y justo cuando lo decíamos, asesinaron a tres personas, y nosotros tuvimos la visión de ver esas cosas.

El que se mete a la prospectiva, tiene el destino de Casandra, te van a dar de palos. Y bueno, ¿yo de dónde saqué esto?, de quienes fueron mis maestros. Yo era profesor de la Facultad de Ciencias Políticas y Sociales de la UNAM, todavía era "la escuelita" en 1967-1968, saliendo de la facultad en un día de 1968, vi los tanques ocupando Ciudad Universitaria, así que me autoexilie en otro país, entonces un Instituto de París me recibió, no encontré lo que yo estudiaba acá pero decidí quedarme y ahí fue que conocí a mis maestros, y aquí ya les voy a empezar a hablar de nombres: Edgar Morin; me gustó porque tenía un seminario que decía: 
Sociología de los medios de comunicación, asistíamos como 300 personas. De repente Morin, cambió su programa a Teoría de sistemas, estuve un tiempo, pero no era lo que buscaba y me fui un día a una escuela de economía de la Universidad de París I y encontré una puerta cerrada con un letrero que decía: Centro de Estudios del Porvenir (en francés), y la raza, es raza aquí y en París, los jóvenes le pusieron: se lee la mano y se ve la bola mágica; en lugar de quitar el letrero sólo doblaron la parte donde decía eso y ya, pero todos abríamos el pedacito. El caso es que nunca se veía abierto y no veía a nadie en esa oficina.

Preguntando a la secretaria me indicó que en unos días iniciarían las clases. Llegué a la clase de licenciatura y ahí encontré a un tal Bertrand de Jouvenel; un señor muy distinguido; noble; conde, pero no le gustaba ser conde, prefería ser barón porque ese no tiene poder. Bueno, eso es lo que me decía.

Yo como buen salvaje mexicano, con todo y plumas, me acerqué a un pensador que ni siquiera sabía quién era: Bertrand de Jouvenel creí que era como cualquier otro profesor de la Universidad, o una persona más. Después de dialogar con él, al subir al elevador me hizo tres preguntas dificilísimas de tecnología; de pensamiento, yo contesté que no sabía, pero lo que sí sabía era que yo quería estudiar esas cosas del porvenir. Y yo creo que lo salvaje de mí, le cayó bien.

Y entonces supe por qué nunca estaba abierta la puerta, porque él tenía un palacio, donde estaba toda la historia de la Prospectiva; y además en una biblioteca chica, pero preciosa. Jouvenel me distinguió con su amistad, con esta anécdota quieren que sepan cómo fui conociendo quién era Bertrand de Jouvenel, yo tenía que trabajar porque no me fui becado, yo daba cursos de creatividad en España, me contrató una empresa francesa, la tercera más importante y en una ocasión me invitaron a comer en Campos Elíseos, al final del seminario Bertrand de Jouvenel me invitó a comer a lo cual me negué por tener un compromiso con el reclutador de la empresa; en lugar de tomar el metro, tomé un taxi, lo cual es un gravísimo error en París, llegué más tarde de lo previsto, me disculpé por el retraso argumentando que había estado con Bertrand de Jouvenel y que no había ido a comer con él, a lo cual mi interlocutor repitió lo que había dicho, ¿dice usted que estuvo con Bertrand de Jouvenel?, pues sepa usted que yo siendo el Director más importante de esta empresa llevo tres años solicitándole una cita y no me la concede y a usted que lo invita a comer Bertrand de Jouvenel, usted no va, y para no insultarle ya no le dije: es que yo como a cada rato con Jouvenel.

De Bertrand de Jouvenel tomé esa seriedad, ese rigor que él mismo no se atrevía a hablar de prospectiva, sino de conjetura; su libro más importante para la prospectiva El arte de la conjetura, en español le llamaron El arte de prever el futuro politico, 
un nombre más comercial. Su libro trata del poder, y ese libro está considerado al mismo nivel de Platón. Cuando falleció Jouvenel se publicó un libro con muchos textos de él, enorme, con su retrato, tenía una facilidad extraordinaria para escribir.

Luego abrí otra puerta al conocer a René Thom, quien fuera galardonado con la Medalla Fields, que es el doble de difícil de obtener respecto al Premio Nobel; fue premiado por su teoría de las catástrofes; tomé su seminario donde describe su teoría en un modelo matemático, topológico, y también señala las trece dimensiones sobre las que se formó el mundo. Así me fui de Francia a Bélgica donde estuve en la Universidad de Lovaina y Bruselas, (que como dato curioso en ese entonces, los títulos de Doctor en Filosofía los firmaba el Papa, hubiera sido interesante tenerlo, puesto que yo pecador, igual y así ya tenía el pase directo al cielo), ahí estuve estudiando con Jean Baudrillard quien me recomendó estudiar con Ilya Prigogine, quien estaba estudiando estructuras disipativas y le llamó la atención y me invitaron a participar en un estudio sobre estructuras disipativas y urbanismo, de cómo se producen estos fenómenos y vienen las catástrofes, las estructuras disipativas anuncian previamente lo que va a ocurrir. Catástrofe en sentido amplio; ahí fue donde ya estaba en la prospectiva, le presagié que le otorgarían el Premio Nobel, dos años después se lo dieron, cuando yo venía de regreso a México.

Ya en México me incorporé de nuevo a la FCPys, e inauguramos la materia de Prospectiva en la carrera de Sociología, y en el Doctorado un Seminario de Prospectiva Social. Lo que dice la Dra. Guillermina Baena con toda propiedad es que esta Facultad era marxista, ustedes no se imaginan, entrar a un centro marxista con cosas de matemáticas, de computadora, entonces me insultaban diciendo que era funcionalista, ni me preocupaba, y a pesar de eso se lograron abrir ambas materias. Digo es algo en un grupo de ese tipo, no les puedo contar las dificultades que pasamos, como difícil era meter una computadora en esta Facultad.

Hicimos un estudio para una Secretaría de Estado sobre el impacto social del medio ambiente; nos pagaron miles de pesos que se donaron a la Facultad, con eso íbamos a comprar las computadoras, y claro las computadoras nunca llegaron, se rumora que ese dinero se lo gastó la dirección de la Facultad en sendos banquetes.

Después me fui de Ciencias Políticas a Rectoría, y tiempo después me fui de la UNAM, estuve vagando mucho tiempo, aunque en mi corazón siempre estuvo y estará la UNAM. Finalmente llegué a la UVM, en un momento oportuno, porque eso es lo importante que llegue su oportunidad si no, no hay negocio. El Rector de la UVM, el Maestro Nájera, contador, pero con visión, hizo el modelo educativo siglo XXI, donde fundamos el tronco común de la universidad que era: Visión; la 
primera era prospectiva, necesitamos formar hombres con visión que vean lo que viene, la siguiente era creatividad, que genere ideas, la siguiente que sean científicos, por ello epistemología, y por último informática por la transición hacia la sociedad y economía del conocimiento.

Posteriormente, salí de la UVM, ya sea por mi vocación tendiente a estar desorientado, sigo estando desorientado, y bueno acompañé en una campaña al Gobernador de Tlaxcala, mi amigo, quien me premió por mi trabajo en campaña con un viaje a Grecia, así emprendí mi viaje a Grecia junto con mi hijo y otro profesor apasionado de la prospectiva a conocer primeramente el Oráculo de Delfos, iba buscando una frase: "Aquel que ve el futuro jamás será leído", es un lema de los cristianos ortodoxos griegos, quería que me tradujeran la frase al griego antiguo pero resulta que el muro donde aparecía la frase, fue derribado.

De regreso en México, el gobernador sabiendo de mis inquietudes, me cedió dos edificios de una vieja cárcel, donde escogí un viejo molino que data de hace 200 años y un edificio moderno para albergar salones, donde planeé construir un Centro llamado Espacio Prospectivo, y nuevamente el destino de Casandra jugó contra mí, recibimos los edificios en un estado terrible, pasamos dos años remodelando y reconstruyendo. El día de la inauguración, incluso, hicimos un tapete de Huamantla, realizamos algunos eventos hasta que el gobernador me dijo que el edificio sería donado al IPN; luego participé en la construcción del Colegio de Tlaxcala. Seguí en comunicación con el ex gobernador.

De esta experiencia, con los pocos ahorros de la vida, establecí que más vale solo que mal acompañado, fundamos el Centro Internacional de Prospectiva "Gastón Berger", que por cierto yo no conocí a Gastón Berger, ya había muerto cuando yo llegué a Francia, que por cierto su muerte está envuelta en una leyenda, que se suicidó o que murió en un accidente automovilístico en carretera. A su muerte, Francia empezó a corregir el trazado de las carreteras argumentando: No podemos tener accidentes automovilísticos en carreteras donde muera una persona de ese nivel.

Pero uno de los investigadores del Centro estudiaba meteorología porque a través del clima estudiaban el futuro, yo me fui a Suiza, donde cursé un Diplomado sobre meteorología, ahora se sabe que es muy complicado ver el corto plazo pero más fácil es ver el largo plazo en la meteorología, y de ahí me nació la vocación por la astronomía. Ahí es donde me siento feliz porque hay predicciones sensacionales que nadie de nosotros va a ver; primero el sol se va acabar dentro de 4 mil millones de años, va a chocar nuestra Vía Láctea contra la Galaxia de Andrómeda dentro de 3 mil 500 millones de años, o sea, son predicciones de mucha envergadura, o cuando menos de números grandotes que no caben en la cabeza. La 
Tierra tiene otro destino; el universo desaparecerá dentro de 14 mil millones de años, es un mundo astronómico donde las predicciones son estáticas, porque se sabe a dónde va. A partir de ahí construimos un planetario, cumplimos 10 años en diciembre de 2014, y construimos un Museo del futuro para que los niños se enfrenten con su futuro.

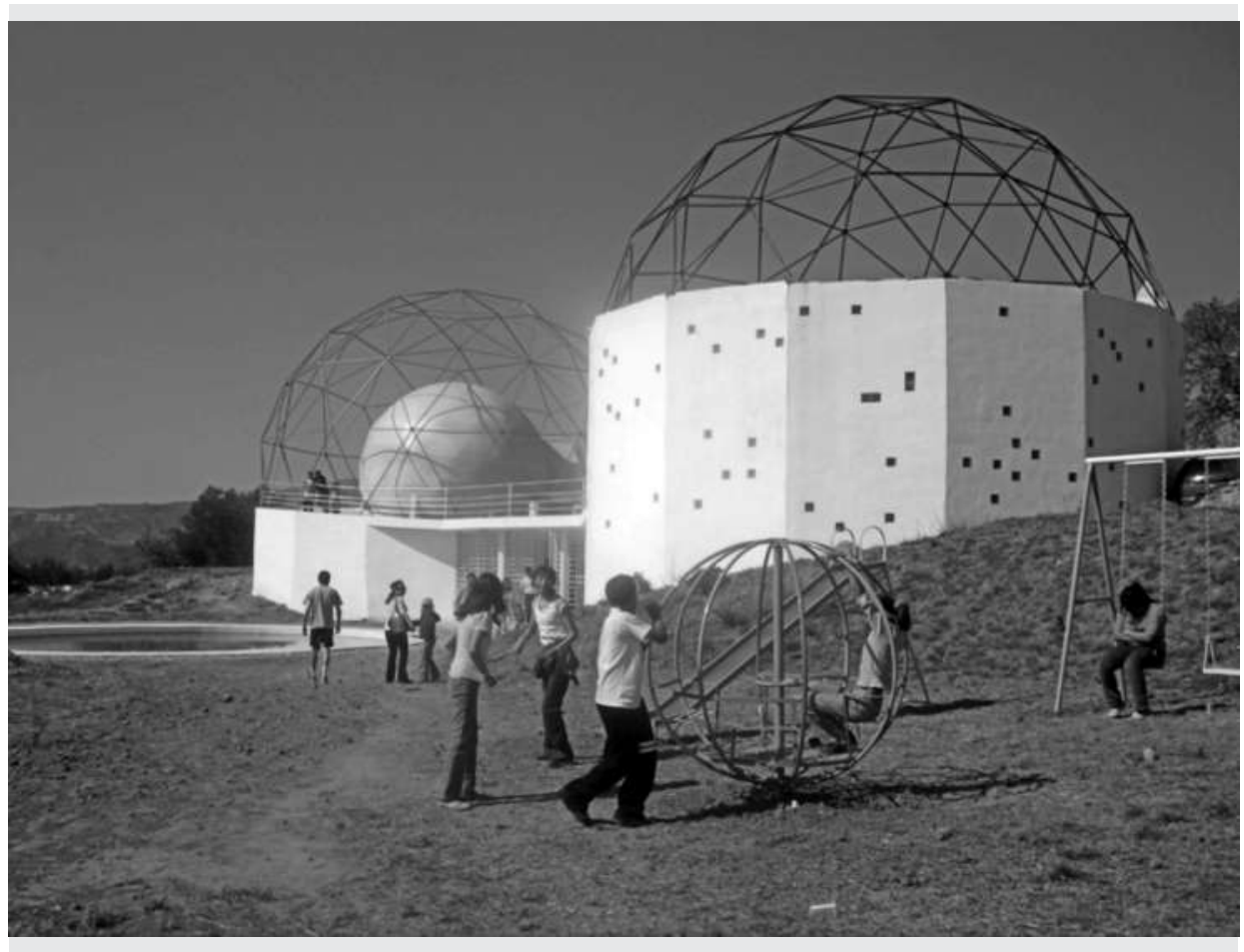

Otra cosa que deben saber es que tenemos pleito los prospectivas e historiadores, es un pleito seguro, nos invitaron a un coloquio sobre historia, fue muy vulgar, los historiadores se fueron con el ponente que era historiador y los prospectivistas conmigo. La Historia dice que es cíclica, que siempre se repite y quien sabe qué, para los prospectivistas, la historia no se repite, y tenemos la sentencia de qué: El que voltea para atrás se convierte en estatua de sal, es más; los libros de texto sobre prospectiva señalan que el pasado ya pasó, se acabó y luego viene el futuro y luego el presente, un poco el esquema de planificación, basado en que el pasado no se puede actuar porque ya pasó, pero sobre el futuro sí. 
Al final se aprobó un museo con 22 salas que se iba a poner en Cancún, en fin, el dinero se lo gastaron nunca se hizo el museo. Y yo, pues arraigado a la frase de Schumpeter: Lo pequeño es hermoso, entonces hicimos un pequeño museo, y un pequeño planetario; con cuatro salas, una dedicada a los objetos imposibles, donde les enseñamos a pensar al revés.

También tenemos una astrocena, que se realiza cada primer sábado del mes, con una visita al planetario, un concierto y una cena en el Museo Futuronio.
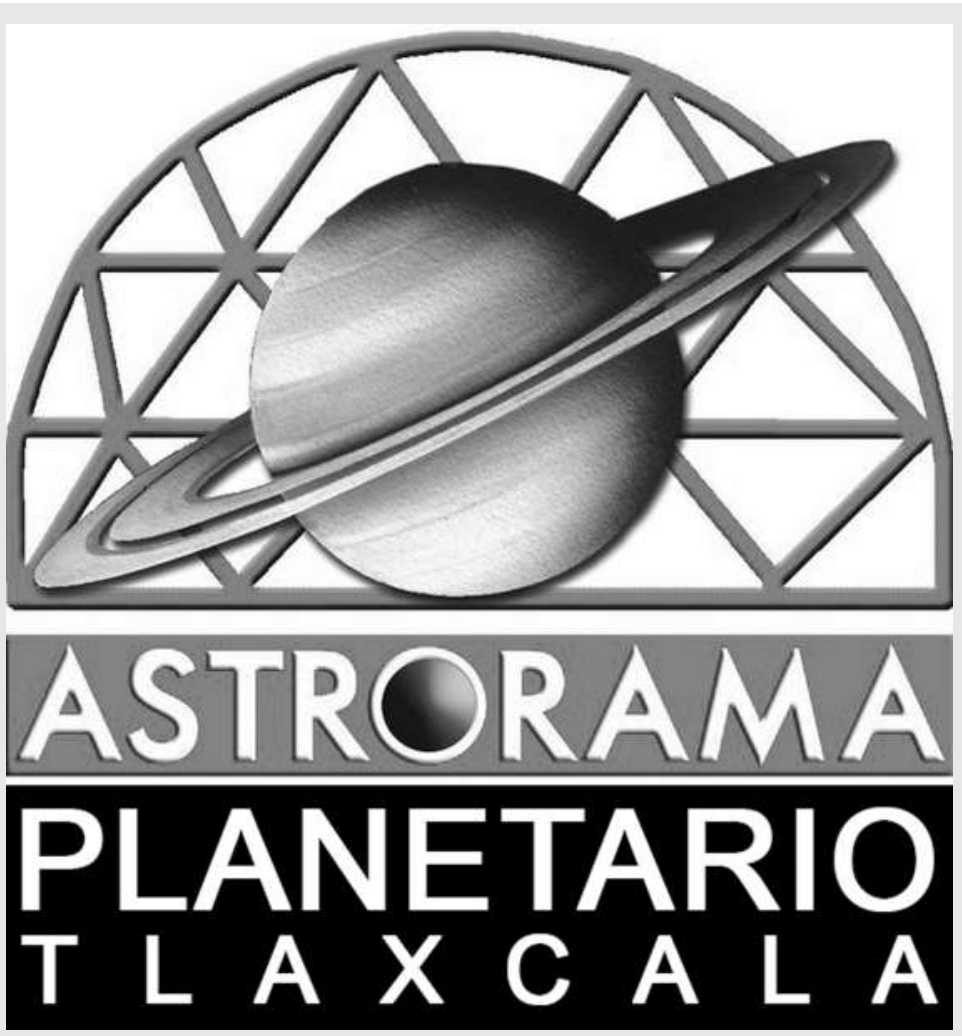

Cierro diciendo que Bertrand de Jouvenel menciona que "Un prospectivista posee una idea civilizatoria, presentar una idea nueva implica que te van a golpear, y luego esos mismos que te golpearon la van a llevar a cabo". 


\section{LA FUNDACIÓN JAVIER BARROS SIERRA: ANTONIO ALONSO CONCHEIRO}

a Fundación Javier Barros Sierra se creó el 7 de marzo de 1975 y fue la primera institución en América Latina dedicada exclusivamente al campo de la prospectiva. Había instituciones como la Fundación Bariloche en Argentina, que sí tenían trabajos de prospectiva desde 1968. A partir de la década de los años sesenta, fue cuando empezó a haber algunos trabajos de prospectiva en el extranjero. En particular, en Venezuela y Argentina, fueron los dos primeros países en donde, vinculados a los Congresos Interamericanos de Planificación, se empezaron a hacer esfuerzos del pensamiento prospectivo.

La Fundación Javier Barros Sierra se crea en un México peculiar. Hasta 1968, se vivía lo que Enrique Krauze llamó "una dictablanda", para diferenciarla de las dictaduras. Había un partido en el poder, fuera de ese partido en el poder no había nada, es decir, no había ninguna posibilidad de participar políticamente. Era un sistema presidencialista y clientelista, en el que más allá de las atribuciones que, formalmente, tiene el presidente, también tenía muchas otras. Era, pues, el dueño y señor del país. México era un país en el que no importaba saber qué o saber cómo, lo que era importante era saber quién. Las relaciones personales públicas eran mucho más importantes que cualquier otra cosa. México vivía en una economía cerrada, o relativamente cerrada, entonces los grandes negocios nacionales eran los que se construían a través del "compadrazgo". Cuando se nombraba un secretario o ministro, se exclamaba: ¡Ah, ese fue compañero de escuela! ¡seis años de lujo para mí! En otros casos, se preguntaba: ¿Qué sabes hacer? -Nada, pero soy amigo de 'fulano' de tal, se respondía.

Resulta extraño, entonces, que la Fundación se haya constituido en México, un país que se reinventaba cada seis años. Era una especie de "gatopardismo", en el 
que "se cambiaba todo para que no cambiase nada". Cada nuevo presidente decía: Todo lo que se hizo atrás no sirve. Le cambiaba los nombres a los programas que había, "borrón y cuenta nueva". Así, la necesidad de pensar en el futuro en esos términos era pensar en la siguiente administración. Aún más, en adivinar quién iba a ser el próximo presidente, porque había que estar cerca del candidato. Había una expresión política que, durante muchos años, se denominó "El tapado", la cual se empleaba para designar a quién fuera el incógnito sucesor del presidente priista en turno. Justo un año antes de que empezara el cambio de presidente, había nombres que circulaban -todavía el partido no decía quién iba a ser su candidato- esos eran "los tapados" y se jugaban tretas unos a otros para ver quién, finalmente, era nombrado candidato a la presidencia. Era seguro que el candidato a la presidencia del partido en el poder sería el presidente, no había ninguna duda.

Entonces era un juego en el que el futuro no tenía mucho sentido.

Sin embargo, en 1968, el movimiento estudiantil -movimiento que terminó siendo un movimiento popular-cambió la ecuación y empezó a mostrar que había otras posibilidades de juego y eso le movió "el tapete" a muchos de los políticos y a muchos de los tomadores de decisiones, que dijeron: las cosas están cambiando y pueden seguir cambiando.

En 1973, a Emilio Rosenblueth le otorgaron el Premio de Ciencias "Luis Elizondo". Emilio era ingeniero, tenía un doctorado en ingeniería civil. El premio debió haber sido del orden de cinco mil dólares; no lo iba a sacar de pobre, ni tampoco haría alguna diferencia en sus finanzas personales. Entonces él se cuestionó: ¿Qué hago con el dinero del premio que sea útil para el país? Conversando con un grupo de amigos ingenieros, le sugirieron: ¿Por qué no creamos un "tanque de pensamiento" (think-tank) que se dedique a pensar en el futuro del país? Algunos de ellos desempeñaban tareas de planeación en obras públicas. Siempre andaban con la pregunta: ¿Qué carreteras debemos construir? ¿De dónde a dónde? ¿Será mejor construir un puerto o un aeropuerto? Entonces, finalmente, decidieron que sí lo harían. Se constituyó un grupo núcleo, que después fue el que terminó siendo el grupo de asociados más importante de la Fundación para crear el centro dedicado exclusivamente a pensar en el futuro de largo plazo e, incluso, en el futuro a largo plazo de cualquier asunto que resultase de importancia o de interés para México. Eso quiere decir que la Fundación podía estudiar los futuros de Medio Oriente, si eso -se pensaba- podía vincularse con el futuro del país o podía dedicarse a hacer un análisis de los futuros del sistema educativo nacional. Lo que no estaba muy claro era si se podía hacer un estudio en torno a los futuros de una empresa en particular. Eso quedaba descartado cuando se decía: Tiene que ser de interés 
nacional. Excepto si esa empresa era Petróleos Mexicanos (PEMEX), pues aportaba los mayores ingresos del presupuesto público; podía, entonces, ser importante hacer un análisis de los futuros de PEMEX. Pero, en general, la idea era estudiar grandes sectores de la economía o de la política. Así, la Fundación se constituyó gracias a Emilio Rosenblueth quien cedió el dinero de su premio.

Es imprescindible señalar quién fue Emilio Rosenblueth. Él era una mente privilegiada, era un personaje alto -debe haber medido alrededor de 1.90 metros. Crítico siempre, con una pipa que mordía y hablaba entre dientes; lo que no hacía fácil entenderle. No era fácil comunicarse con él. El medio de comunicación más efectivo que tenía Emilio, era un papel "chiquito" que mandaba o "disparaba". Al día, debe haber "disparado" 40 o 50 de esos papelitos. Cada vez que uno recibía un papel -era uno afortunado por recibir uno de esos papelitos de Emilio-, se ponía uno a temblar, porque además no olvidaba ninguno de los papelitos que enviaba y al cabo de una semana preguntaba: ¿Oye ya tienes respuesta para mí? Las preguntas eran tales a las que uno decía: ¿Cómo contesto? Es que no tengo ni la más remota idea de qué puedo hacer con esa pregunta que me hace. Por ejemplo, mandaba un papelito con la pregunta: ¿Cuál es el valor de la vida humana? Y uno exclamaba: ¿¡Cuál será el valor de la vida humana!? Era, además, un personaje cultísimo, le encantaba el cine y no se perdía ninguna de las reseñas mundiales del cine que se hacían en México. Le encantaba la música, era melómano de "hueso colorado"; tenía una colección de discos maravillosa. Era siempre sarcástico, duro. No era fácil mezclarse con él, pero también era una persona muy generosa. Con una enorme ética y con una enorme capacidad para provocar a la gente para que fuese mejor. Porque cada uno que recibía un papelito, temblaba; uno tenía que hacer su mejor esfuerzo.

En 1975, conocí a Emilio Rosenblueth, justo cuando se estaba creando la Fundación. Yo venía con un doctorado en ingeniería recién obtenido y, bueno, era bastante presuntuoso; me sentía que acaba de conquistar el mundo. Era doctor y ya podía hacer cualquier cosa. Yo era ingeniero mecánico eléctrico de mi carrera de origen y Emilio era ingeniero civil. En el Instituto de Ingeniería de la Universidad Nacional Autónoma de México (UNAM) - a donde regresé a trabajar- había un comité editorial que revisaba lo que se publicaba en unos cuadernillos. A mí me mandaron un trabajo de Emilio sobre la aplicación de la probabilidad bayesiana a un problema de ingeniería sísmica de estructuras. Luego de la revisión del artículo, le mandé ocho o nueve páginas de comentarios. Algunos de ellos eran: Está equivocado en tal cosa. Otros eran incluso del uso del lenguaje: Parece que es incorrecto emplear tal o cual término. A los tres o cuatro días, recibí de regreso 
cinco cuartillas de Emilio refutando todas las observaciones que había señalado. En algunos casos, cuando se trataba del uso de alguna palabra, por ejemplo, la respuesta de Emilio era del estilo: En la reunión de tal fecha de la Real Academia de la Lengua Española, se aprobó el uso del término tal. Tuve el descaro todavía de decir: ¡Ah no, pues en esta palabra no estás bien! Le volví a contestar dos o tres páginas adicionales con comentarios a sus comentarios. Así, un día, al caminar por los pasillos del Instituto, Emilio Rosenblueth me preguntó: ¿Tú eres Antonio Alonso? —Si, contesté. Ven, él reviró. Me sentó en su escritorio y me dijo: Hace mucho tiempo que nadie se atrevía a regañarme por un artículo mío. Te agradezco mucho que tú hayas tenido el atrevimiento de decirme que estoy equivocado en esto y de insistir, además, en defender tus puntos de vista.

Ahí nació una gran amistad con Emilio. Yo seguía mi carrera como ingeniero, no tenía ni la más remota idea que se había creado la Fundación Javier Barros Sierra, ni me interesaba. Estaba dedicado al área de información de la ingeniería de control automático. Y, lo que son las cosas en la vida, hubo una especie de revuelta entre los investigadores de la Coordinación de Automatización del Instituto de Ingeniería, porque el coordinador de automatización renunció al cargo. Todos nos sentíamos tan autónomos y seguros de nosotros mismos que se dijo: No necesitamos de ningún coordinador, es decir, cada uno de nosotros se va a coordinar solito y no hay ningún problema. Entonces se tuvo una reunión con el director del Instituto para decirle que nos negábamos a que hubiese un Coordinador de Automatización. Tomé la palabra y mencione todas las razones por las que no se requería un Coordinador. Después de unas semanas, el Coordinador era yo. Porque nadie estuvo detrás de mí; todos pensaron que iba a ver represalias. Entonces, como nadie me apoyó, me dijeron: ¿Por qué no eres tú el coordinador? Así seguía yo mi carrera como ingeniero.

Lo que sé, pues, de los primeros años de la Fundación es lo que aprendí cuando ingresé a la misma o por lo que me habían comentado. Entre el grupo núcleo que, junto con Emilio Rosenblueth, constituyeron la Fundación se encontraba Fernando Solana. Él es politólogo, maestro en las facultades de Economía, Filosofía y Ciencias Políticas y Sociales. Él también había cursado la carrera de ingeniería civil. Fernando era Secretario General de la UNAM, justo en los tiempos del movimiento estudiantil de 1968. Él es un personaje central para la Fundación. Político extraordinario y que, posteriormente, sería dos veces Secretario de Educación Pública, Secretario de Comercio, Secretario de Relaciones Exteriores, Senador. Él era, pues, uno de los que convencieron a Emilio de que se crease la Fundación. Es un hombre visionario y siempre fue un apoyo muy importante para la Fundación. 
Estaba también Víctor L. Urquidi. Él era economista, hijo de un ingeniero egresado del Instituto Tecnológico de Massachusetts (MIT). Creo que Víctor fue uno de los economistas más importantes en los inicios de la Comisión Económica para América Latina y el Caribe (CEPAL). También, era fundador del Club de Roma; lo habían invitado a formar parte de los miembros fundadores. Él había participado en la Conferencia de Bretton Woods (1944). Para ese entonces era presidente de El Colegio de México. Era todo un personaje.

Formaba parte de ese grupo núcleo, también, Carlos Abedrop. Él era banquero, era presidente de la Asociación Nacional de Bancos, cuando sucedió la expropiación de la Banca Nacional, en la época de López Portillo. Carlos era dueño de un banco, de uno de los bancos más importantes del país. Era una persona muy conservadora. Cabe mencionar que, años después de la formación de la Fundación, a finales de la década de los años ochenta, Carlos me pedía que le escribiese alguno de los discursos cuando tenía que dar para alguna conferencia. Entonces, escribía lo que diría en esa conferencia y luego él lo volteaba y decía lo contrario de lo que yo había escrito. A Carlos Abedrop le encantaba: — ¡Oye, qué bien! ¡Qué bueno! ¡Qué ideas tan buenas tienes! Me juntaba con él una vez al mes a desayunar en su casa y le decía: - Pero todo lo que te mando es lo contrario de lo que yo pienso, Carlos. - Pero lo haces muy bien, respondía. Él era otro personaje que siempre apoyó muchísimo a la Fundación y que también fue un actor central.

Estaba, de igual manera, Daniel Díaz Díaz, personaje todo lo contrario a Emilio Rosenblueth. Él era de baja estatura, regordete y muy vivo. Daniel Díaz era Director General de Planeación de la Secretaría de Comunicaciones y Obras Públicas. Él fue quien, de hecho, generó la idea de que se crease la Fundación. Después él llegaría, también, a ser titular de la Secretaría de Comunicaciones y Transportes. Él era otro personaje clave e importante de la Fundación.

Sin embargo, el grupo núcleo que se formó no sólo eran ingenieros, estaba también Jaime P. Constantiner. Él era médico de formación, pero en realidad era más un financiero, tenía compañías de seguros. Esa combinación de gente pensante, de gente con dinero y con buenas intenciones, permitió que los primeros cinco años de vida de la Fundación creciese verdaderamente.

En principio, la Fundación se instaló en el Palacio de Minería, en el centro de la Ciudad de México. Ese edificio era sede de la entonces Escuela Nacional de Ingenieros de la UNAM. Allí, le prestaron a la Fundación unos cuantos salones para que pudiese operar. Y, bueno, arrancó de manera muy modesta, pero en esos primeros cinco años hizo algo que resultó muy importante: publicar una serie de cuadernillos y de libros acerca del quehacer de la prospectiva, eran "estados del arte" 
de los modelos matemáticos aplicados al pensamiento prospectivo. La Fundación hizo esa serie de cuadernillos, esencialmente, porque el grupo de investigadores inicial estaba aprendiendo qué era la prospectiva; después de ciertas lecturas, se hacía un resumen y se editaba como un cuadernillo en español. Esa serie se convirtió en un punto de referencia muy importante para toda América Latina.

Entre algunos de los títulos del Centro de Estudios Prospectivos de la Fundación Javier Barros Sierra, inmediatos y posteriores a ese periodo, se encuentran: Wladimir M. Sachs (1980), Diseño de un futuro para el futuro. Un ensayo de los métodos e importancia de la planeación prospectiva, México, Fundación Javier Barros Sierra; Antonio Alonso Concheiro (1987), México: rasgos para una prospectiva, México, Fundación Javier Barros Sierra; Gerald O. Barney y Antonio Alonso Concheiro (comps.) (1988), Estudios del siglo 21, México, Fundación Javier Barros Sierra/ Editorial Noriega-LIMUSA; Tomás Miklos y María Elena Tello (1991), Planeación prospectiva: una estrategia para el diseño del futuro, México, Fundación Javier Barros Sierra/ Editorial Noriega- LIMUSA; Eleonora Barbieri Masini (1993), La previsión humana y social. Estudios sobre los futuros, México, Fundación Javier Barros Sierra/ Fondo de Cultura Económica. (Nota de J Correa)

La Fundación empezó a tener impacto, incluso, más allá del país. En 1982, unos siete años después de su creación, la Fundación llegó a tener 130 miembros de personal académico, lo que la hacía una institución enorme. En 1980, el presidente de entonces, José López Portillo, le hizo como donativo a la Fundación el terreno que hoy tiene como patrimonio. Además, instruyó para que el organismo federal encargado de la construcción de escuelas construyese el edificio. Construyeron un inmueble muy sencillo, pero extremadamente funcional, sensacional. Finalmente, en 1980, la Fundación se trasladó a las instalaciones que están en la carretera al Ajusco, justo al lado de El Colegio de México y de la Universidad Pedagógica Nacional. Esas instalaciones me servían a mí cuando yo estaba en la Fundación como director. Para describir la ubicación de la Fundación, que estaba entre El Colegio de México, el Fondo de Cultura Económica, la Universidad Pedagógica Nacional, la Facultad Latinoamericana de Ciencias Sociales y más allá un parque de diversiones, decía que: La Fundación estaba justo entre la academia y el parque de diversiones. Es una bonita manera de describir lo que allí se hacía.

Sin embargo, en 1982, la Fundación pasó por una primera gran crisis. Había crecido demasiado rápido y con un conjunto de académicos "rebeldes", porque estaban, primero, en un campo en el que se estaba abriendo brecha y, segundo, en uno en el que se valía casi todo. Entonces empezaron a organizar un sindicato, lo que es natural. Así, la Fundación vivió una enorme crisis que casi la hizo cerrar. 
En ese lapso, entre 1975 y 1982, la Fundación tuvo cuatro directores. El primer director fue Felipe Lara Rosano -quien había sido mi maestro-. También él se había formado en el área de sistemas de control. Felipe Lara era investigador del Instituto de Ingeniería de la UNAM. Era natural, pues, que la Fundación estuviese dominada por personajes que estaban vinculados con el Instituto, porque el fundador-Emilio Rosenblueth-era investigador en dicha institución. Entonces, persona que Emilio detectaba en el Instituto, la colocaba en la Fundación. El segundo director de la Fundación fue José Manuel Covarrubias, él fue Tesorero de la UnAM y director de la Facultad de Ingeniería (1991-1995; 1995-1999). El tercer director fue José Antonio Esteva. El cuarto director fue Tomás Miklos, a él fue al que le estalló la crisis. Tras esa crisis - que casi hizo desaparecer a la Fundación-, quedaron menos de diez investigadores.

Resulta pertinente hacer un paréntesis. Había desarrollado ocho o nueve años de tareas administrativas en el Instituto de Ingeniería. Primero como Coordinador de Automatización y luego como Subdirector de Áreas de Automatización, Instrumentación, Mecánica, Fluidos y Térmica. En esa época, quería hacer un año sabático cuando se me liberara de esas tareas. Como parte de las funciones que tenía en la Subdirección se estaban desarrollando algunos proyectos de energía solar, aprovechamiento de la biomasa y demás.

En el Consejo Nacional de Ciencia y Tecnología (CONACYT) existían los Programas Indicativos de Ciencia y Tecnología; participaba en dos de ellos, uno era en industria eléctrica y electrónica y otro era en energía. La función de estos programas era recibir las propuestas de investigación de todas las instituciones, se lanzaba una convocatoria para presentar proyectos y llegaban alrededor de 80 a 90 propuestas, entonces se repartían. Éramos seis miembros en cada programa y se repartían las propuestas para su evaluación. Cada vez que nos reuníamos en el programa de energía, me preguntaban: — ¿Cuáles hay que apoyar? —Éste y éste, contesté. - ¿Y, por qué esos dos sí y no los otros dos?, de nuevo me preguntaron. - Porque esos dos son de mis amigos; los otros no los conozco, respondí. Entonces, me dijeron: — ¡Qué cínico eres! ¿Esa es la única razón? —Sí, esa es la única razón: son mis amigos, contesté. Cuando me preguntaron: —¿Por qué eres tan cínico? Les dije: - A ver, yo no sé cuál es la fuente de energía más importante, ¿Cómo comparo un proyecto para desarrollar técnicas de plasma y otro de casas solares? ¿Cómo hago para evaluar a cuál deberíamos de apoyar? No hay ningún criterio, no sé qué fuente va a ser importante para este país en el futuro. Tantos cuestionamientos ofrecí que finalmente dijeron: - Bueno, vamos a hacer un ejercicio para revisar cual sería el futuro de cada una de las fuentes de energía. 
Y, como ocurre siempre, me pidieron que yo hiciese un estudio de energías solar, eólica y biomasa. Al cumplir el plazo para la entrega del informe, llegué y le dije al presidente del programa: Aquí está el informe. Te puedo decir que lo único que sé, es que ya cumplí administrativamente, pero el informe es una porquería. Lo que aprendí en el proyecto es que no sé qué pensar en el futuro. Entonces, haz lo que puedas con eso, pero no estoy convencido de que sirva para algo. Finalmente me dijeron: Ya puedes desprenderte de tus tareas administrativas. ¡Sensacional!, respondí.

Para ese entonces, había mantenido conversación por carta con alguien que había escrito un libro sobre la historia del control automático, que a mí me había capturado; entonces empecé a interesarme en la historia del control automático. Finalmente, cuando llegó el momento de tomar un año sabático dije: Ahora me voy a ir a estudiar la historia del control automático. Le escribí una carta a mi contacto: "Oye, estoy interesado. ¿Qué tengo que leer? ¿Dónde tomaría los cursos sobre la historia del control automático?" La respuesta que recibí fue: "Yo era el curador del control automático del Museo de Ciencia y Tecnología de Múnich, pero me nombraron director. Así que ahora está vacante la plaza de curador, ¿Por qué no vienes a pasar tu año sabático como curador?" Bueno, ante esa respuesta brincaba de la felicidad. En ese momento, me cruce con Emilio Rosenblueth y me dijo: Te veo muy contento. Pues sí, contesté, me voy a ir un año sabático a estudiar la historia del control automático en Múnich. ¿Y por qué la historia y no el futuro?, él me reviró. -Acabo de entregar un informe y me di cuenta que no sé pensar en futuro; por eso voy a estudiar la historia, le respondí.

— ¿Tú sabes para que son los años sabáticos? Emilio me preguntó. —-Bueno, para hacer cosas de las que uno no puede hacer normalmente, porque tiene otras actividades, aprender algo que uno no sepa, le respondí. - Si no sabes pensar en el futuro, ¿Por qué no te vas a estudiar cómo pensar en el futuro?, él me cuestionó.

-No existe nada para pensar en el futuro, finalmente concluí. Sin embargo, él propicio -creo-que nos encontráramos cinco o seis veces y todas las veces me dijo exactamente lo mismo: - No seas tonto, vete a estudiar el futuro. Finalmente le dije: - A ver, tú me insistes mucho; yo lo haría si me dices en donde puedo hacerlo. Estaba muy seguro de que no había nada que se llamase un centro para estudiar el futuro. Y me dijo:

-Pues fíjate que creamos en México un centro, ¿Por qué no te vas a pasar el año sabático ahí? Era la Fundación Javier Barros Sierra.

Con mucha tristeza abandoné mis planes de irme a estudiar la historia del control automático y dije: Bueno, está bien, voy a hacer un esfuerzo. Me fui supuestamente a incorporar a la Fundación Javier Barros Sierra. 
En ese entonces, el presidente de la Fundación era Daniel Ruiz Fernández, otro personaje muy importante. Él era el Gerente General del Comité Administrador del Programa Federal de Construcción de Escuelas (CAPFCE), organismo que se dedicaba a construir las escuelas públicas federales. Daniel Ruiz también era ingeniero; había sido Director del Instituto de Ingeniería de la UNAM (1970-1974). Había tenido un pleito jurídico muy importante con él; cuando era administrador del Instituto, rompió un poster de Ernesto "Che" Guevara que tenía en mi cubículo, por esa razón renuncié a ser becario. Me había enfrentado públicamente con él. Y, bueno, fui a su oficina. Me recibió muy gentilmente, me ofreció un café. Tenía siempre impecables sus cosas; no había ni un sólo papel en su escritorio. Sabía que era una persona muy ocupada, pasaron 15 minutos y seguíamos charlando del clima, cuestiones de las escuelas públicas. A la media hora le dije: - Me da mucha pena, sé que estás muy ocupado, no llega el Director de la Fundación, Tomás Miklos, entonces lo espero aquí afuera y cuando llegue, le decimos a su secretaria que me reciba y ya vemos como me voy a incorporar a la Fundación. Mis preguntas eran: "¿Quién me va a enseñar a pensar en el futuro? ¿Me voy a incorporar en un proyecto o hay que generar uno o hay que hacer una propuesta?" Todas las situaciones que uno piensa en ese momento.

La respuesta de él fue: —No. Tomás no va a venir. — iAh, bueno! Pues si quieres podemos hacer la cita otro día, le respondí. - No, es que renunció la semana pasada, finalmente acotó. En ese momento pensé: “iUf! Con la burocracia de la UNAM, ahora voy a tener que volver a empezar el trámite. Me van a aprobar el año sabático aquí en la Fundación. A lo mejor, ya no puedo irme a ningún lado.” ¡Qué terrible! Bueno, pues, ni modo, dije. Pero, en ese momento, después de nuestra plática, Daniel Ruiz me preguntó: ¿Por qué no eres tú el Director de la Fundación? - No entiendo nada; yo vengo aquí porque quiero aprender a pensar en el futuro. ¿Cómo voy a dirigir una institución que se dedica a pensar en el futuro? No, le respondí. —A ver, ya sabemos todo eso. ¿Tú sabes leer?, me insistió. —No sé, digo, sé interpretar los signos que están escritos en una página; no sé si eso sea "saber leer", pero sí puedo reproducirlo en sonidos, le contesté. - Pues hay una biblioteca en la Fundación sobre prospectiva, entonces, lee. Ahí puedes aprender, él me dijo. Me quedé pensando: "Se va tardar como cuatro o cinco meses rehacer las cosas en la burocracia de la UNAM, ¿Qué hago? Se me va acabar el año sabático antes de que pueda hacer nada." —Bueno, pues, ¿Cuántas gentes hay en la Fundación?, le pregunté. —No hombre, hay seis o siete investigadores, él contestó. —-Bueno, está bien. Me creo todo lo de la Fundación, le respondí. Así llegué yo al campo de la prospectiva. 
A la semana de estar como Director de la Fundación -en un edificio que era para 130 personas, habíamos seis o siete-, me fue a ver Fernando Solana -en aquél entonces era Director General del Banco Nacional de México y me dijo: —Quería saber si tú no tienes inconveniente en que yo converse con los investigadores de la Fundación. - No sé, yo apenas los conozco; conversa con ellos, le contesté. No tenía inconveniente. También quería saber si podía venir una vez a la semana para aprender qué es esto de la prospectiva, Fernando agregó. —Sí hombre, hay todos los cubículos que quieras, el ochenta por ciento está vacío; así que selecciona el que más te guste. No hay ningún problema, le respondí. También, quisiera saber si es posible que me prepares una lista bibliográfica de qué sería bueno que leyese para aprender, él me dijo. - Eso sí no; porque no tengo ni la más remota idea. ¿Cómo te voy a decir qué? Estoy empezando a ver qué libros hay en la biblioteca. Si me das un tiempo y si encuentro algo que me parezca interesante, te lo mando. Pero ahorita no te puedo dar lista bibliográfica de nada, le respondí.

A la semana siguiente -fue dos o tres veces a la Fundación- y a la tercera visita me dijo: — ¿Puedo hablar contigo? —Sí claro, le contesté. Se sentó enfrente de mi escritorio y me dijo: - Yo en realidad a lo que vine, es que estoy pensando si cierro o no la Fundación. — ¿Cómo? A ver, explícame, le respondí.

- Sí, es que ha habido muchos problemas y realmente estoy pensando si vale la pena mantenerla abierta o no; entonces quiero saber si la cierro o no. Le dije: Una cosa es que tú quieras cerrarla y otra es que la cierres. Tú eres uno de los miembros de la Fundación, hay muchos otros miembros. Tú no tomas las decisiones por los demás, tiene que haber una asamblea que sea la que decida si continúa o no la Fundación y te aviso que yo voy a estar del otro lado. Yo voy a defender que esta institución siga abierta. Aquí, a mí no me vas a decir que tú la vas a cerrar. Entonces se fue. A la semana me llamó por teléfono y me preguntó: ¿No se te ofrece nada? —No, gracias, le respondí. — ¿No necesitas dinero?, él preguntó. —No, gracias. Estamos muy bien, no hay ningún problema. Ya no has venido aquí, a la Fundación, a aprender. Ahora, sí ya te puedo empezar a dar libros, si quieres, le contesté. Así estuvimos como un año y medio. Tuvimos una relación inicialmente muy ríspida, pero después siempre estuvo detrás de la Fundación, siempre nos apoyó en todo lo que se necesitaba.

Nunca tomé un curso, no tuve la fortuna o la falta de la mala suerte de tomar un curso de prospectiva. Lo que sé de prospectiva es lo que me enseñó la vida a golpes, cometiendo errores garrafales. Los primeros textos que -hoy leo- y que escribí en la Fundación, digo: — ¡Qué locura! ¡A quién se le ocurrirían estas cosas! Aprendí de la manera dura, qué cosas sí y qué cosas no había que hacer. 
Por ejemplo, cuando yo llegué a la Fundación, esos seis investigadores estaban desarrollando un modelo de simulación de la economía nacional. Algo que era muy cercano a mi campo, pues era el área de sistemas. Yo había hecho, e intentado, hacer algún modelo de simulación de la economía en el Instituto de Ingeniería, me sentía en mi campo y, por supuesto, como no sabía ninguna otra área más que esa, pues ese era el proyecto que teníamos entre manos. A los dos meses de estar en la Fundación, me atreví a presentar los resultados de los primeros meses al Consejo de la Fundación. La primera vez, después que terminé mi exposición, me preguntaron: — ¿Y dónde está incluida la deuda? — ¿La deuda?¿Cuál?, reviré. —La deuda pública, cerca del 60 por ciento del producto interno bruto debería estar incluido ahí, me contestaron. —No, no está incluida, les respondí. —El modelo no sirve para nada, respondieron. Al mes regresé con un "parche" en el modelo. — ¡Ya está la deuda!, les dije. Entonces discutimos, se quedaron muy contentos y uno de ellos levantó la mano y dijo: -iY el precio del petróleo, cómo influye ahí? — ¿El precio del petróleo? No, no está en el modelo, les respondí. _ ¿Cómo? La economía mexicana se está "petrolizando"; en el futuro va ser muy importante. El precio del petróleo debe estar ahí. Si no está el precio del petróleo, tu modelo está mal, me comentaron. - Denme un mes, les respondí. Regrese al mes. —Ahí está el precio del petróleo en el modelo, les dije. Después de presentar unas gráficas, alguien me preguntó: -Y esa curva que sube y baja, ¿Qué es? - Es el indicador E27, le respondí — ¿Y qué es eso?, de nuevo me preguntó. —Denme cinco minutos, voy por el manual de variables del modelo, les dije. Entonces, cuando iba de regreso, buscando el E27, pensé: "iQué estupidez! ¡Qué estoy haciendo yo aquí!. No puedo juzgar ni siquiera el sentido común de lo que estoy presentando. No sé cuáles son las variables que están ahí. ¿Para qué estoy aquí haciéndome tonto?” Entonces llegué y les dije: -El E27 es el indicador tal, pero me acaban de convencer de que hay que hacer otra cosa. El modelo de simulación quedó archivado. Aprendimos mucho, sí pero nada más. Entonces, había que estudiar otras herramientas. Las primeras, obviamente, las más fáciles para mí eran las cuantitativas: estimación bayesiana, métodos de impactos cruzados. Delfos, talleres del futuro ¿Qué es eso? Simplemente no tenía las herramientas, ni estaba cercano a eso; entonces, para mí "los temas eran campos minados, cada vez que corría me explotaba una mina." No sé manejar un grupo; soy bastante tímido como para andar aquí exhibiéndome. Además, tenían que ser expertos y los expertos eran los amigos de los miembros del Consejo. Entonces me ponían unas revolcadas terribles. ¡Era espantoso!

Así, la Fundación tuvo diez años de estabilidad mediocre conmigo al frente; porque casi no sabía nada de prospectiva. Era bastante atrevido, por ejemplo, se me 
ocurrió hacer el primer ejercicio de prospectiva nacional. A partir de 23 sectores se elaboró un ejercicio a México 2010, desde la política, hasta la economía, pasando por la educación, la energía, las telecomunicaciones, los transportes, los materiales; todo lo que se me ocurrió sumando 23 temas. Y luego en cada uno de los temas, había que tener un grupo asesor. El grupo asesor eran expertos de cada uno de esos temas, los convocaba para que dijesen qué indicadores debíamos tener para construir una enorme base de datos. La mayor parte de la energía eran números, pues eran para construir la base de datos. A todos los miembros de la Fundación mandaba resúmenes con tablas desde 1925, con información, por ejemplo, sobre la producción de llantas en México. ¿Qué tenía eso que ver con el proyecto? Pues nada, pero yo tenía la información.

La Fundación sí hizo algunas cosas interesantes: publicó algunos libros. El grupo de 10 o 15 investigadores que, en ese entonces, colaboramos en la Fundación aprendimos algo sobre prospectiva, o sea, cumplimos con la función de formar recursos humanos en prospectiva. Hubo algunas publicaciones, por ejemplo, el libro de Tomás Miklos, Planeación prospectiva: una estrategia para el diseño del futuro, se convirtió en una referencia dentro de la literatura sobre prospectiva en América Latina.

De cualquier manera, el rumbo de la Fundación en sus primeros años se vio también modificado -digamos- por una nueva ocurrencia de la que luego me arrepentí durante mucho tiempo. Pero ni modo, son las cosas que uno comete de joven y de viejo, y las sigo haciendo igual. En la literatura había algo que se llamaba "evaluación de riesgos". ¿De qué se trataba? Pues decir: "¿Cuál es la probabilidad de falla de una central nuclear? ¿Cuál sería el costo en vidas, en recursos materiales, si fallase esa central nuclear? Entonces, se hacía una evaluación sobre el riesgo de que fallase la central nuclear." Pensaba, pues, que eso es lo que hacía la prospectiva: ¿Cuál es la probabilidad de que ocurra un evento y qué consecuencias tendría el evento? En una conversación con Emilio Rosenblueth se me ocurrió proponer un grupo de análisis de riesgo dentro de la Fundación y así aprenderíamos cómo se hacen esos estudios. Había un amigo de Emilio, él estaba en la Universidad de Waterloo en Canadá, era el director de un centro de análisis de riesgos. Él es un personaje que debe haber estado vinculado con Emilio desde que eran estudiantes, porque también era de la misma universidad donde Emilio había hecho su doctorado, también había pasado un año como investigador en el Instituto de Ingeniería e, incluso, había pasado un año, por lo menos, como investigador de la Fundación. 
Entonces, me pareció sensacional; ya conocía la Fundación. Así, empezamos a trabajar la idea de crear un centro de riesgos dentro de la Fundación -un pequeño grupo. Y sucedió el terremoto de 1985. Así, de manera muy natural, la prospectiva terminó siendo el análisis de riesgo sísmico, por lo cual, la Fundación debería contar con un centro de análisis de riesgos sísmicos. En ese entonces, la tarea del registro y medición de los sismos era una tarea "poco glamorosa", no le gustaba al Instituto de Ingeniería y tampoco la requería la gran empresa de construcción ICA (Ingenieros Civiles Asociados); entonces, por qué no crear un Centro de Instrumentación y Registro Sísmico.

La Fundación quedaría como una "institución paraguas", y debajo habría tres centros: el Centro de Estudios Prospectivos, el Centro de Investigación Sísmica y el Centro de Instrumentación y Registro Sísmico. Los centros de Instrumentación y Registro Sísmico y de Investigación Sísmica tenían además una tarea, que surgió en una plática entre Emilio y yo, yo decía a ver, no se pueden anticipar todos los sismos como tal, pero una vez que ocurren es mucho más lenta la onda sísmica que una onda eléctrica, entonces porque cuando se sienta en un lugar una sacudida, por qué no mandamos una señal eléctrica que diga ahí viene, no sé si se puede no hacer una lectura pero ahí empezamos a cocinar la idea de por qué no se podía tener una alarma sísmica.

Bueno, pues, era muy natural que uno de ellos iba a desarrollar la alarma sísmica, pero era un ejercicio de prospectiva de corto plazo 30 segundos o 25 segundos por lo mucho; pero podía ser muy importante. como la alarma sísmica tuvo éxito, y estábamos ya divididos en tres fuerzas porque teníamos tres centros, teníamos que mantener el Centro de prospectiva, mantener el Centro de investigación sísmica, mantener el Centro de instrumentación y registro sísmicos y éramos los mismos changos los que estábamos ahí, mantener todo lo que antes a duras penas podíamos mantener en uno, bueno ahora ya teníamos tres, finalmente con el éxito que tuvo la alarma sísmica y demás, la Fundación empezó a cambiar de giro y ya no era fácil de identificar qué hacía la Fundación, "ah son los que hacen las cosas de la alarma sísmica", no, no, hacemos prospectiva, y "qué es eso", no, no somos de los sismos.

Emilio era una figura a nivel nacional notable, el sismo de 1985 lo había hecho todavía más notable, había ganado el premio Príncipe Asturias, era todo un personaje. En paralelo en el Centro de prospectiva, empezó a pasar algo que a mí también me empezó a disgustar, yo ya había encontrado un acomodo más o menos cómodo, entonces ya no estaba innovando mucho, yo ya sabía hacer las cosas, sabía hacerlas, hacía una tras otra, lo mismo en la administración que en la estruc- 
tura, que en el tipo de proyectos, en todo, entonces yo rodaba pero no avanzaba; segundo, había mucha gente que ya no sabía muy bien si el Centro de estudios prospectivos era Antonio Alonso o si Antonio Alonso era el Centro de estudios prospectivos y yo decía eso es lo peor que le puede pasar a una institución, que la institución sea un individuo, entonces repetidamente presentaba yo mi renuncia al Consejo cada vez que nos reuníamos, y el Consejo muy sabiamente decía sí, sí claro tienes toda la razón, danos un tiempecito para encontrar quien te supla, y pasaban seis meses, oigan ya mi renuncia, sí, sí claro, tienes razón, tenemos que juntarnos para ver quién te va a suplir y así total, yo estuve trece años o catorce años y finalmente creo que para fortuna de la Fundación el Consejo me dijo ya te puedes ir y pusieron a alguien, por cierto a alguien muy entrañable amigo mío Jorge Elizondo Alarcón muy respetable.

Primero pudimos convencer al Consejo de que la idea de tener tres centros era mala, si cada centro tenía una función que cumplir podía cumplirla de manera autónoma y por ende cada uno de los centros podía operar por separado, y en el de estudios prospectivos pues no tenía caso que hubiera la Fundación Javier Barros Sierra y el Centro de Estudios Prospectivos, desaparecemos este, regresamos a la Fundación y los otros dos se separan y funcionan de manera independiente y finalmente así lo hicimos, se volvió a concentrar todo en la Fundación, pero en ese proceso.

En esos 12 años cambió el país y cambiaron las cosas que para la Fundación representaron una segunda gran crisis, para empezar, muchos de los fundadores miembros asociados de la Fundación como es natural pues se hicieron más viejos, la Fundación va a cumplir el año próximo 40 años de vida y no sólo eso, muchos de ellos llegaron a su pico de poder y empezaron a tener menos poder, el cambio natural generacional en cualquier cosa, y eso qué quería decir para la Fundación, vemos menos campeones con capacidad de acción para beneficiar a la Fundación y conseguir más recursos para que siga siendo; segundo, con esto de la apertura de la economía nacional y demás y la transparencia empezaron a haber cada vez más limitaciones para el sector público al menos, para que el sector público federal y estatal hiciese con activos a las Fundaciones o a las asociaciones civiles y eso quiere decir que la Fundación ahora tenía que competir con cada uno de esos proyectos de prospectiva que se plantease.

Pero una cosa es convencer a un funcionario público, o a un ministro, o a un cuerpo colegiado, que necesita la prospectiva y otra es convencerlo de que lance un concurso, porque necesita la prospectiva, porque para él eso ya es un trabajo adicional, una cosa es decir, bueno, bueno házmelo, cuánto necesitas, tanto, hazlo 
y me lo entregas y vamos a ver si verdaderamente es cierto, es muy sutil y otra, tengo que poner la maquinaria burocrática a pensar en las bases de una licitación para que se haga un estudio que yo no entiendo muy bien cuál es, Toño sí lo entiendo, pero yo no sé muy bien qué es eso de la prospectiva, no tengo gente preparada en prospectiva, entonces qué va a hacer, él va a preparar las bases de la licitación y luego va a concursar en ella, no se pueden hacer las dos cosas, o hacer las bases o concursar y como no tengo quien haga las bases, mejor lo dejamos para otra ocasión. Sí, tienes razón, es importante, no, luego lo hacemos, el Estado forma a sus gentes.

Entonces empezó a haber un estrangulamiento de los recursos de la Fundación y además dentro de esa política de que ahora todo se paga pues empezaron a subir el impuesto predial, el agua, subieron los gastos, bajaron los ingresos y hubo una enorme crisis en la Fundación y otra vez estuvo a punto de cerrar, navegó lo mejor que pudo pero su perfil, su nivel de influencia y capacidad de hacer cosas fue notable. En los últimos cuatro o cinco años hemos hecho un esfuerzo por retomar a la Fundación y cambiarle el perfil, sabemos que no podemos mantener una planta de investigadores dentro de la Fundación, pero queríamos los recursos para asegurar la nómina y no los tenemos.

Empezamos entonces a pensar en que cuál podría ser el papel o la función de la Fundación y dijimos bueno, pues puede ser un centro de opinión en el que convoquemos a un grupo de personas sobre el tema de energía, de cuáles pueden ser los futuros de la energía y que problemas enfrentaría el país si pasasen tales o cuales cosas en energía y luego hacer una conferencia de prensa y decir miren esto es lo que un grupo de estudiosos sobre el campo piensan sobre energía y hacer eso sobre educación, sobre política, sobre cualquier cosa, si podemos tratar de seguir con la tarea de divulgación de la prospectiva publicando libros, cuadernillos, algún boletín.

La Fundación empezó a recuperarse, tomamos la decisión de rentar las instalaciones, primero para poder pagar las deudas que teníamos y segundo, ver si podíamos hacer algún capital que nos permitiese tener recursos para hacer cosas un poquito más de mayor importancia. Eso requiere recursos, la Fundación empezó a despegar nuevamente y en el último año de fines de 2013 y la mitad de 2014 entró en una tercera gran crisis, otra vez de carácter económico financiero.

Por el año 2000, la Fundación con sus dificultades económicas volvió a achicarse y como parte de ello liquidó a los trabajadores que tenía, tres de ellos se inconformaron e iniciaron un pleito laboral, no sé si en Colombia pase lo mismo, pero aquí hasta hace poco por lo menos un pleito laboral, la justicia aunque dicen 
que para que la justicia sea rápida, en México no es muy rápida, el caso es que el juicio se prolongó por diversas razones, hubo una primera resolución favorable a la Fundación. Los trabajadores impugnaron la resolución jurídica y volvió el proceso y mientras tanto el taxímetro de salarios caídos va corriendo, hubo una segunda resolución favorable a la Fundación y ellos volvieron a justificar basados en unos argumentos que además son bastante absurdos, alguien a quien se había despedido en la fecha fulana de tal, tres años después la habían llamado para ver si participaba en otro proyecto de investigación y resulta que justo en ese momento el director de la Fundación despidió a los otros dos que estaban allí y lo mismo ocurrió con los otros dos que también habían sido llamados para a pesar de que estaban en pleito con la Fundación, el caso es que como subió tanto el taxímetro y la justicia en este país es transparente, limpia y pulcra y no es nada corrupta ya había un monto de dinero suficiente y a la instancia última, definitiva e inapelable perdimos el caso, todos los recursos que habíamos acumulado hasta ese momento fueron insuficientes incluso para pagarles a los trabajadores, en paralelo esas instalaciones que teníamos rentadas a un Colegio, el Colegio dejó de pagar la renta y ni se van, ni pagan la renta, deben ya más de medio millón de dólares y siguen sin pagar la renta y siguen sin desocuparlo, estamos en un pleito legal para que paguen y desalojen las instalaciones.

Pero eso hace que la Fundación no tenga ningún recurso pero ni para pagar las cuentas del predial, entonces estamos inmersos en una tercera gran crisis en la Fundación de la que yo espero que podamos salir pronto para poder seguir haciendo cosas, yo no me voy a dar por vencido, soy terco como una mula, la Fundación va a seguir operando con o sin crisis financiera, esa es la historia un poco de la Fundación.

Qué repercusión tuvo o ha tenido en la aplicación de políticas públicas: es una pregunta que es muy difícil de responder, es frecuente que la gente diga oye y qué ha pasado con todas las cosas que ustedes hicieron, qué cambió, no sé, cuál fue la repercusión de los límites de crecimiento del Club de Roma. Juzgado en el muy corto plazo, a los dos años de haberse publicado el informe, lo criticaron, lo hicieron pomada por todos lados, en el muy largo plazo la sociedad tomó conciencia de que hay restricciones en los recursos naturales y no se puede seguir creciendo y usando esos recursos de manera arbitraria, que hay un límite, que el planeta es finito y por ende los recursos son finitos, entonces yo les diría, les puedo contar algunas anécdotas de proyectos que si tuvieron impacto por lo menos durante un tiempo chiquito pero en general yo les diría que el impacto que hemos tenido tiene que ver más con la divulgación, la difusión de la prospectiva 
que con el cambio de las actitudes de los tomadores de decisiones yo creo que si hay cosas que pueden atribuirse al menos a la Fundación como el que hoy hay, dicen que en los ministerios lo que llaman de planeación prospectiva, aunque no haga prospectiva pero ya dice prospectiva, realmente no podría contestar si el impacto que ha tenido la Fundación ha sido grande, mediano, burdo; para ser honesto no sabría cómo medirlo.

Cómo llegaron o por qué están en el asunto de la prospectiva, yo ya les dije un poco como llegué a la prospectiva, pero creo que hay dos o tres factores que son importantes, que explican por qué uno abandona su profesión y la cambia, yo creo que hace 40 o 50 años alguien que cambiaba de empresa a lo largo de su carrera, más de una vez, tenía algún problema, hoy está mal visto que te quedes más de 3 o 4 años en un mismo lugar.

Déjenme pues agregar nada más dos o tres cosas, yo me fui a Londres a hacer el doctorado. Un paso atrás yo era un pésimo estudiante, los primeros tres años de la Facultad de Ingeniería, pasé mucho más tiempo en la Facultad de Ciencias Políticas y en la Facultad de Ciencias. En la Facultad de Ciencias Políticas, por lo menos pasaba tres meses del año, porque había cursos de verano, venían a estudiar español algunas chicas de fuera y había que estar presente, soy realista, ni modo; y en la Facultad de Ciencias el resto del año, porque las mujeres que estudiaban ciencias, biología y demás eran guapísimas y en la Facultad de Ingeniería, como me imagino que ocurre en todos los demás lugares, había 13 mil alumnos y una lady, estaba muy dura la competencia, ahí no había nada que hacer.

Yo en los primeros tres años de la Facultad de Ingeniería era un pésimo estudiante, que me aparecía al final de los cursos a preguntar de qué va ser el examen, si hubo tareas en el curso, qué vieron, de qué se trató la materia, qué hay que estudiar para el examen, y ahí los amigos me ayudaban, le dedicaba dos semanas, por supuesto que en dos semanas después, no tenía yo ni la más remota idea de lo que había aprendido en esas dos semanas, se me había olvidado todo. Era además tan mal estudiante, que yo decía de diez preguntas ya contesté 6 , yo creo que más o menos ya, han de estar bien, me salía del examen.

Yo participé activamente en el movimiento del 68, yo era uno de los líderes, detrás de los líderes, no es fácil ser líder detrás de los lideres, pero yo era el proveedor de ideas, yo creo que en ese movimiento una buena parte de los líderes estudiantiles no tenían ninguna formación política, la practicaban porque estaban enojados, porque en una manifestación habían golpeado a su hermano o a su amigo, porque la policía era muy arbitraria, porque el ejército había matado a cuatro, pero no tenían una formación política clara, quienes sí la tenían, eran normalmente 
miembros o parte de alguna organización en aquel entonces prohibida, como el Partido Comunista Mexicano y en esas organizaciones había que seguir la línea del partido, había que ser disciplinado, yo no era ni lo uno, ni lo otro, entonces yo no podía formar parte de esos partidos porque no era disciplinado, pero sí era un proveedor de ideas para los líderes, cuando decían algo que me parecía inconveniente, tenía que decírselos en las reuniones del Consejo Nacional de Huelga.

Pero justo regresando del movimiento estudiantil, me encontré con un colombiano, que acababa de regresar invitado a México como investigador, de hacer su doctorado en MIT en el área de mi especialidad, Roberto Canales Ruiz, y la primera de las clases, cosa inusitada en la Universidad, hasta ese entonces por los maestros, puso en el pizarrón su teléfono y donde estaba su oficina localizada en el Instituto de ingeniería, para que lo pudiésemos ir a visitar si teníamos dudas a lo largo del curso. Puso los libros, una serie de libros de videoconferencia en el pizarrón y nos dijo en tal fecha va a ver tales tareas, en tal fecha el examen, yo me dije pues que es esto, está fuera de todo. Pero me interesó el personaje, hoy es mi compadre y yo en aquél entonces usaba el pelo un poco más largo de lo que era común y además, eso de usar zapatos, era muy incómodo, había que usar huaraches, y el cinturón era muy poco colorido, entonces había que ponerse unas de esas bandas aquí amarradas, pues más colorida era la vida y este amigo el primer día de clases no era de los que se sentaran, se ponía cómodo en sus clases. Entonces había un amigo mío, un compañero mío, se nos quedó viendo y dijo: ustedes dos, para qué vienen, ya no vengan, no van a pasar; -ino vamos a pasar ¿por qué? -Pues con esa apariencia cómo creen pasar el curso, jah! ahora resulta que por la apariencia no voy a pasar el curso, pues voy a pasar el curso, por primera vez me puse a estudiar; la materia era defender el Control I. Llegó el primer examen, yo me sentía como nunca, había estudiado todo el primer bimestre o lo que fuese, con toda mi alma, el curso, cuando nos dieron las calificaciones, en una escala de 0 a 10: tuve 3- ¿cómo? A ver, yo normalmente me presento una semana antes de los exámenes, apruebo todas con 6 , con 7 , en esa escala de 0 a 10, suficiente para pasar y ningún problema, aquí me dediqué en cuerpo y alma, ¿y 3?, esto no está bien, está mal, algo pasó. Entonces fui y me dirigí al maestro y dije: a ver, yo estudié, ¿por qué saqué tres? Porque no sabes mecánica, no sabes ingeniería, no sabes nada, no importa que hayas estudiado control, pero no sabes las bases, no sabes electricidad, no sabes magnetismo, no sabes nada. Pues yo dije bueno, está bien, acepto que no sé nada, porque la verdad, es que no sabía yo nada. ¿Dónde estudio mecánica? pues me dio los libros, ¿dónde estudio electricidad?, y ¿dónde estudio magnetismo? Entonces al final del curso, ya sabía yo un poquito de inge- 
niería, por lo menos de las bases, la física, química y otros. Y no solo eso, ya era yo el ayudante del profesor, pasé. Entonces como pasé, me dijo: ¿no quieres ser ayudante mío? Sí, ¿por qué no eres becario del Instituto de ingeniería? Suena bien, me van a dar dinero por seguir estudiando, pues me parece muy bien.

Tienes que tener 8 de promedio, para ser becario del Instituto. No, tengo como 6.2 , entonces creó una plaza nueva, se llamaba aspirante a becario, yo fui durante dos años aspirante a becario, pero finalmente cuando fui ya becario, terminé la carrera con 8.0, suficiente para ser becario, entonces me hicieron becario, y en esos andares, se me ocurrió poner un poster del che Guevara en mí cubículo, era una de esas biografías chiquitas, y el administrador del Instituto de Ingeniería era un ex militar, rígido, entonces se le hizo muy fácil, entró en mi oficina, dijo: aquí en el Instituto de Ingeniería no, de ninguna manera, y lo arrancó, entonces yo estallé en furia y en esos andares, jugué con la idea de incorporarme a las guerrillas. Aquí no se pueden hacer las cosas formalmente, si quiero cambiar de país, hay que hacerlo de otra manera. Fui incluso un par de días al campo de entrenamiento, y el segundo de los días que fui, dije: a ver, a ver, ya viste tu color de piel, tu apariencia, tú que vas a llegar a la sierra y al hablar con un grupo de campesinos, de indígenas en hebreo, y les vas a decir: compañeros, te van a ver y van a decir, quien es éste, pero ni de lejos nos parecemos, en qué les vas hablar, en castilla, no te van a entender ni un cacahuate, yo a duras penas aguanto los zapatos, me tengo que poner botas, y a las dos horas, voy a tener unas ampollas, me empezó a dar miedo, yo nunca había tenido un arma en la mano, y tener un arma es una sensación muy especial, entonces dije, que tal que me voy a hacer un doctorado, cuando uno es doctor y uno opina, pues le hacen a uno más caso, y ya puede uno cambiar el país ipor qué no nos vamos a hacer un doctorado entonces?

Me fui a hacer el doctorado, la primera semana en Londres, fui a la biblioteca de la Universidad de Londres y me encontré que había un salón como del doble de este tamaño, lleno de anaqueles de libros en español, que bien, aquí puedo conservarme, además yo tenía problemas muy serios para esto del inglés, en esa primera semana nos pusieron a tomar un curso y entonces el profesor siempre empezaba la clase diciendo: "first of all", yo decía hay un festival, esto se pone..., yo no sabía que los ingleses eran tan..., finalmente me atreví como al cuarto día y levanté la mano, y dije que cuándo era el festival, todo el mundo se me quedó viendo muy raro y dijo no, no, "first of all", ah perdón.

Como verán, no me sentía yo muy cómodo con la literatura inglesa, entonces finalmente pasé como tres horas escogiendo tres libros que me iban a ayudar, prestados por la semana, para leer. Y en esa semana me quedé pensando y dije; 
yo voy a estar aquí como medio preso como unos 3 años, para que ando seleccionando libros, entonces tomé una bolsa de esas de mercado, para que a la semana siguiente llegue al cuarto ese, y dije estos, me voy a llevar estos prestados, luego a la siguiente semana me llevo los que siguen, luego los que siguen y los que siguen, pregúntenme cuánta ingeniería estudié mientras hice el doctorado. Pero sí leía yo a los poetas místicos españoles del siglo XVII, era maravilloso, les cuento todo esto porque cuando regresé, finalmente, aquí a México, y me regresé a la ingeniería cada vez que tomaba un libro que no era sobre Martín Gallas, me sentía culpable, decía yo, hay muchas cosas de ingeniería que no sé y yo aquí estoy leyendo Cortázar, qué es esto, estoy muy mal, estoy equivocado, quita a Cortázar, vamos a seguir leyendo.

Y cuando finalmente llegué a la Fundación y dijeron que todo servía para pensar en el futuro, fue un acto liberador maravilloso, ahora puedo leer lo que me dé la gana y estoy cumpliendo con mi deber, éste es el campo en el que yo quiero estar, entonces no me costó tanto trabajo abandonar la ingeniería, la verdad es que entré como en una especie de acto liberador, un campo de estudio en el que lo mismo se vale leer poesía, que a los clásicos, que biotecnología, nanotecnología, o ingeniería o matemáticas, o todo eso, finalmente todo va a servir. Les cuento esto porque algunas veces, en las pláticas informales con amigos, me dicen: ¿no te parece así como abrumador, que tienes que incluir cosas de todos los campos? No, me parece maravilloso, maravilloso.

La segunda cosa que terminó por convencerme, es que finalmente tuve que aceptar que había que hacer reuniones con expertos, y resulta que para que fuesen más válidas, tenían que ser más expertos. Y esos personajes en general, son personajes encantadores, y aprende uno muchísimo con ellos, entonces empezó, en lugar de ser una tortura, era para mí eso de juntar un grupo y tener que hablar con ellos, empezó a ser sensacional porque me juntaba y aprendía como esponja, con todos ellos, cada vez que conversaba con uno de ellos, era un líder en su campo de pensamiento, y eso era súper enriquecedor, entonces terminaba el fin de una semana, terminaba diciendo: qué maravilla, hay gente que vale la pena, no todo está tan mal, como cuando lee uno el periódico, yo creo que esas son de las cosas que aprecio más de la prospectiva. Independientemente si tiene un impacto o no, cambió al mundo o no lo cambió, personalmente se enriquece uno de manera enorme, como ninguna otra profesión que yo conozca.

Aprende uno la jerga de todas las profesiones, porque para hacer preguntas el que recibe la pregunta tiene que entenderla, y eso obliga a que quien hace la pregunta, tenga que hablar el mismo lenguaje que quien recibe la pregunta, 
entonces uno termina adquiriendo una especie de metalenguaje, que incorpora todos los dialectos que hablan los distintas especialidades, los distintos campos del conocimiento y es riquísimo, porque esta uno en una reunión de médicos y uno puede conversar con ellos, de lo que ellos hablan, y se va uno a una de físicos y pasa exactamente lo mismo y se va uno a una de biólogos y también podemos hablar con ellos. Entonces sí, es una cosa que siente uno que espiritualmente está todo el tiempo estimulado.

Dicho eso, debo decirles que Guillermina lo sabe, porque alguna vez me preguntó que como estaba yo, y le dije que de la patada, me dijo: ¿por qué? ¿Qué tienes, problemas de salud? y. le dije no, tengo hecho un nudo en la cabeza, no entiendo muy bien qué es lo que está pasando pero empiezo a ser muy crítico con lo que hago, y es muy difícil trabajar, seguir haciendo cosas, hace poco leí a alguien que decía: "es muy difícil seguir intentando probar teoremas, cuando uno sabe que las bases del sustento que uno está usando para probar los teoremas no son sólidas".

Y estoy pues en una etapa un poco introspectiva; tratando de saber por qué no somos capaces de darle esa solidez que debiera tener una buena prospectiva. Como algunos de ustedes, ya tomaron, muchos de ustedes ya tomaron una charla conmigo antes, yo creo que tenemos que hacer un esfuerzo de construir a la prospectiva, pero de verdad construirla. Hay muchas cosas que hacemos de manera automática, que aceptamos de manera automática, que realmente no tenemos ni un sustento, ningún apoyo firme para acercarse.

No ha disminuido mi fe en el campo, sigo convencido de que es importantísimo pensar en estar sobre él, pero lo que no estoy seguro es que podamos vender las herramientas que usamos como la solución a ese problema del cómo reflexionar sobre el futuro. Me han invitado, por ejemplo ahora, a construir algunos ejemplos del uso de herramientas como las codesianas en las cuales si cambia uno el valor de las evaluaciones que uno hace inicialmente, obtiene resultados absolutamente distintos, mi pregunta es entonces ¿cómo podemos, qué tenemos que hacer? No para no usar esa herramienta, sino para que esa herramienta no tenga esas deficiencias, no es fácil.

Yo tengo más preguntas que respuestas, pero bueno, yo creo que lo primero que hay que hacer para tener respuestas es tener las preguntas, porque a lo mejor me estoy haciendo las preguntas equivocadas, y cuando llegan las repuestas, a lo mejor tenga que volver a la ingeniería, quien sabe para mí sí ha sido una experiencia transformadora, el llegar hasta estos lados, sí ha sido útil o no, no sé, para mí sí ha sido útil, les agradezco. 


\section{PROSPECTIVA EN MÉXICO Y LATINOAMÉRICA, EDUCACIÓN Y PROSPECTIVA: AXEL DIDRIKSSON}

uchísimas gracias, muy buenos días tengan todas y todos, sean ustedes muy bienvenidos a su país hermano, viniendo de donde vienen según me ha comentado la Doctora Baena, tenemos lazos de cooperación, de colaboración, de intercambio académico, de proyectos, de elaboración de estrategias y política pública, desde hace muchos años, a nivel general con Colombia, tanto en distintas Universidades, en Cali, en Medellín, en Cartagena, el mismo Bogotá, en el Externado, en la Javeriana y la propia Nacional de Colombia, junto, por supuesto, con otros países.

Y es muy grato saber que las camadas de generaciones que están trabajando y reflexionando sobre estos temas fundamentales siguen estando vigentes en el Externado, con nuestro gran amigo y por supuesto experto el Doctor Mojica con quien iniciamos hace ya algunos años, no voy a decir cuántos, él que les diga, pero ya hace muchos años estos esfuerzos de pensar el futuro desde la perspectiva del presente para transformarlo.

Voy a dividir esta exposición en una charla abierta con ustedes, como me lo ha pedido la Doctora Guillermina Baena, primero, como primer punto, para decirles la experiencia, el enfoque, el esfuerzo, la orientación, la perspectiva teórico-metodológica que imprimimos hace unos 15 o 20 años más o menos, cuando comenzamos con los trabajos de estudios del futuro y de largo plazo, qué enfoque y cuál fue la particularidad con la que construimos la primera red latinoamericana prospectiva, hoy hay muchas, desde entonces nuestros referentes eran dos, eran tres, en lo particular uno era en la Federación de prospectiva, aquí directamente vinculados con Alonso Concheiro a quien seguramente ustedes ya conocen y con Eleonora Barbieri el segundo, digamos un referente más interesante para nosotros, más cercano, metodológica 
y teóricamente lo sentíamos mucho más cerca de la problemática latinoamericana. Los futuribles de Bertrand de Jouvenel y la corriente de Godet, franceses, nos daban herramientas mucho más técnicas y metodológicas, pero que teóricamente no nos satisfacían, con enfoque mucho más hacia la empresa, que al desarrollo social o a instituciones de servicio social y el otro que nos quedaba más cerca, pero igual de lejos, como dice nuestro refrán, "tan lejos de Dios y tan cerca de Estados Unidos", que da el enfoque norteamericanista, muy prospectivista, muy dominante, muy gringo como decimos nosotros que es, como el de la World Future Society.

Fuimos a varios congresos invitados, hablamos, y armamos un capítulo latinoamericano, tenemos un Capítulo mexicano que dirige Julio Millán, quien es parte del Consejo de la WFS desde hace muchos años, fuimos dos o tres veces hasta que nos hartamos, de ahí solamente escuchábamos a los estadounidenses creyendo que todo lo que iba a pasar dentro de 20 o 30 años iba a ser idéntico a su dominio, simplemente proyectaban, proyectan el futuro desde la perspectiva fundamental de que van a ser el polo dominante, por imposición militar y tecnológica de sus designios y nosotros le decíamos, no, nada más vean alrededor, se está cayendo, el país ya se endeudó en el mundo, ya perdió las 50 iniciativas tecnológico-científicas en el mundo, es decir, la telefonía celular, las telecomunicaciones, la energética, la petroquímica, la industria naval, que es la militar, el transporte masivo, la nanotecnología, la biotecnología, los láser, la robótica, etc., ellos no tienen el liderazgo, lo tuvieron, pero ya no, digo por lo menos no lo tienen solos, los tienen como una fuerte competencia con Corea, con Taiwán, con China, con Japón, con Alemania, con Suecia, con Finlandia e incluso en muchos casos Brasil, Colombia, México, Argentina, esto era digamos el panorama de entrada y el esfuerzo básico.

El primer punto fue entrar en contacto con quienes estaban realizando trabajos de prospectiva aunque fuera de tipo imitativo o de transferencia de metodologías y teorías como los referentes que acabo de mencionar, pero que nos dieran elementos fundamentales para construir una idea propia porque la veíamos desde la perspectiva de un contexto distinto, los pioneros que nos dieron esta serie de elementos, fueron Amílcar Herrera con el desafío que hizo ante el club de Roma. Recordarán ustedes que sus libros, son libros de referencia que el Club de Roma en los años 60 cuando vino el baby boom define desde un plano malthusiano que iba a ver un crecimiento geométrico de la población y un crecimiento aritmético de los alimentos, o sea que el crecimiento poblacional iba a ir por bloques, por decirlo gráficamente, y el crecimiento alimentario por rangos de tendencia y por lo tanto preveían que para fines del siglo pasado no habría manera de alimentar a tanta gente por la cantidad de población, versus productividad alimentaria; y los 
latinoamericanos de la escuela de América, Argentina, dijeron no, y demostraron en un libro emblemático que fue clave para nosotros diciendo que esto era falso porque primero no era correcta la ecuación, el algoritmo que estaban usando era incorrecto, porque sí estaba creciendo la productividad alimentaria, nada más que estaba distribuida desigualmente, pero entonces vino la cifra brutal de que con el desperdicio de comida de los restaurantes de la ciudad de Nueva York se podía alimentar a un país como Nigeria entero, entero, no es que hubiera carencia de alimentos, cualquiera que vaya a Estado Unidos notará desde que se sube al avión, a un bus o al metro, la perspectiva del desperdicio en términos de las personas y bueno, en México ya también se habrán dado cuenta, es la combinación entre hamburguesas, hot dogs, tacos de nenepil, de buche, espero ya hayan comido unos tacos, es como ir a Bogotá y no comer un ajiaco o una buena empanadita, lo tienen que hacer, aunque se enfermen, nada más no le pongan tanto chile y no coman en la calle por supuesto. Amílcar Herrera fue un referente por eso, porque vio una perspectiva crítica y además un escenario distinto al que presentaba el club de Roma, entonces fue todo un descubrimiento plantearse toda la perspectiva crítica de los enfoques dominantes de la prospectiva, de la prospectiva digamos proyectiva, de la prospectiva tendencial y plantearse que el futuro no podía tener un sólo camino sino que había que construirlo y que podían ser distintos, entonces cuál fue el enfoque original, uno plantearse que en América Latina tenemos que construir herramientas, teorías y metodologías desde el contexto y su aplicación, es decir en perspectivas distintas a las europeas, a la francesa, a la norteamericana, a la asiática, que también entonces empieza a cobrar gran fuerza, ubicarnos en esta perspectiva teórico metodológica con las corrientes más cercanas, que nos parecían más adecuadas al análisis crítico de la realidad latinoamericana caribeña particularmente dos: el análisis de FAST (Forecasting and Assesment of Science and Tecnoloy), que coordinó en el surgimiento de la Unión Europea, Ricardo Petrella, ese documento ustedes lo tienen que leer necesariamente, fue un parteaguas en la perspectiva de cómo elaborar perspectivas, de cómo formular escenarios en la lógica de un proceso de integración, en este caso el Europeo, desde la perspectiva científico tecnológica y de los conocimientos, es un documento que avizora la posibilidad de crear una Europa del conocimiento, se llama así FAST, por sus siglas Forecasting and Assesment of Science and Tecnoloy .

Riccardo Petrella fue uno de nuestros grandes prospectivistas, entonces en la lógica de la integración latinoamericana que es mucho más cercana a la visión que se tenía entonces de Europa, de pasar de la comunidad económica Europea a la Unión Europea y a crear proyectos de Ciencia y Tecnología, y la famosa del 
proyecto Bolonia, que es crear el espacio común de la Unión Europea pues a nosotros nos pareció muy importante recogerlo y dos, los enfoques "foresight" de previsión, de anticipación, más que de proyección que tenían los norteamericanos muy vinculados a escenarios de guerra y a escenarios de dominio que hicieron primero los canadienses y luego se extendieron fuertemente en centros de institutos de educación en Asia, Japón, China, Corea, Taiwán, Singapur.

En sus estructuras gubernamentales se empezaron a desarrollar, les estoy hablando de los años 80 , finales de los 80 , principios de los años 90 se comienzan a instalar centros de anticipación Forecasting and Assesment of Science and Tecnoloy de anticipación científico tecnológica o para fines de política pública, en el gobierno de la India se crea por primera vez el Consejo de conocimientos con científicos para desarrollar la perspectiva del escenario Hindú, en el marco de la globalidad, entonces estos enfoques de Foresight, en lugar de forecasting nos parecían también mucho más adecuados, para no alargarme mucho, si ustedes quieren por supuesto en el diálogo que quisiera yo tener, si quieren apuntar en esta etapa con mucho gusto les daría yo más información al respecto. Pero éste fue el momento, comenzamos a trabajar algunos cursos, tuvimos un fondo de la UNESCO para desarrollar, a finales de los 90, un esfuerzo de creación de la Red Latinoamericana de Prospectiva e hicimos cinco eventos simultáneos en el año 2000, los organizamos entre el 98 y 99, convocamos a los grandes referentes teórico metodológicos, pues no exactamente prospectivistas como tales, pero sí quienes habían hecho algunos esfuerzos metodológicos para comprender coyunturas y perspectivas hacia el futuro como Sergio Furtado en Brasil, el propio Mojica en Colombia y otros como Javier Medina en Universidad del Valle de Cali, Eduardo Balbi en Argentina, Jorge Dobrev en Uruguay, un par de colegas en Paraguay que ahorita no recuerdo sus nombres, Perú y México tenemos a Tomas Miklos, Alonso Concheiro, a Julio Millán, en fin, que ya estábamos pensando en el tema de la prospectiva y comenzamos haciendo el primer evento en La Habana en el año 2000. Iniciamos en enero-febrero del año 2000 pero con un fondo que conseguimos de la UNESCO, hicimos el primer seminario de prospectiva en La Habana, seguimos en México el segundo seminario, dos, tres porque había gran auge en Colombia hicimos un seminario tripartita, entre Cali, Medellín y Bogotá, en el 2000, hicimos el cuarto en Argentina, en Buenos Aires con Balbi y terminamos en Pelotas, Brasil, así se llama la ciudad, y la Universidad de Pelotas nos auspició el quinto seminario, está a un lado de Uruguay, muy pegadito a la frontera Uruguaya en Río Grande Do Soul, a un ladito, en medio entre la frontera Uruguaya y Río Grande Do Soul. Pelotas es una ciudad muy chiquita, muy bonita junto a un río muy precioso, eso 
fue un esfuerzo que nos permitió por lo menos enlazar, recoger ponencias, hicimos un libro de esa experiencia y nos auspicio iesalc, el Instituto Internacional para la Educación Superior de América Latina y el Caribe de la UNESCO que tiene su sede en Caracas, o sea en el 2000 consolidamos la red. ¿Cuál fue el enfoque?, uno, la prospectiva en América Latina tiene que tener una visión integracionista, su escenario debe ser integracionista. Segundo debe allegarse de herramientas técnicas, cajas de herramientas, lo que ustedes quieran, metodologías, pero tiene que ir creando y construyendo perspectivas teórico metodológicas, epistémicas inclusive propias.

No podemos construir esa estructura epistemológica teórico metodológica si no hacemos prospectiva y entendemos a la prospectiva, no como un ejercicio de construcción de escenario al futuro con fines de comparación o de simulación o de contrastación, un escenario deseable frente a un indeseable, un escenario catastrófico frente a un positivo, sino la perspectiva de que la experiencia, la construcción de alternativas y sembrar semillas del futuro, era lo que nos iba a retroalimentar las experiencias teórico metodológicas, esto fue clave para nosotros, esto fue fundamental porque comenzamos a trabajar proyectos de investigación con enfoque prospectivo pero con una visión de construir alternativas.

Entonces, por ejemplo en Brasil, Rosa Alegría desarrolló un Centro comunitario de perspectivas medioambientales, ciudadanas e integracionistas con idea de empoderar a las mujeres en las comunidades, sembró futuro y hoy es una experiencia comunitaria impresionante. Aquí comenzamos a desarrollar modelos académicos novedosos para sustituir universidades tradicionales y ya llevamos cinco universidades creadas, nuevas, con una estructura de modelo académico, organizacional, de carreras, de currículum, etc., que para entonces eran muy novedosos: ya llevamos tres en México, cuatro en Ecuador, una de las cuales estamos dirigiendo, dos en Argentina, dos en Brasil, una particularmente, la UNILA, la Universidad para la Integración Latinoamericana que está en Iguazú, tiene población Latinoamericana y Brasileña en donde el 50\% de la población Latinoamericana está becada, Está entre Paraguay, Brasil y Argentina, ustedes conocen o han oído hablar de las cataratas de Iguazú, una cosa esplendorosa, está en el campus, está en construcción, con cinco carreras con las que comenzamos en el terreno de la hidroeléctrica de Itaipú, yo soy miembro del consejo consultivo y hay otra que se está creando en el Nordeste Brasileño, que es afrobrasileño para desarrollar estrategias de colaboración de futuro entre África y Brasil, pues tiene un chipote así, y si ustedes ven el mapa de África tiene un hueco así, si ustedes lo juntan, como nos decían los de primaria, caben exactamente, perfectamente, 
tenemos toda una conformación geográfica única, claro, las capas tectónicas, los cambios en la tierra, etc., hicieron que se fueran desprendiendo cuando entró el mar, pero somos una sola cosa, en fin, así hemos venido desarrollando este tipo de experiencias en otras latitudes, se han desarrollado proyectos tecnológicos en informática muy muy avanzados, proyectos de biotecnología, temas sobre agua, temas sobre seguridad nacional, por ejemplo Balbi es experto en temas sobre seguridad nacional, temas de energía y petróleo y como corriente digamos en términos de formación el Externado se orientó mucho al desarrollo de la prospectiva y la estrategia en términos empresariales.

No fue el enfoque nuestro, el enfoque nuestro fue mucho más social institucional y con definición de políticas de estado, que desde entonces estamos desarrollando por ejemplo, con el Instituto Nacional de Altos Estudios de Ecuador donde está la sede de la sección para la educación, ciencia y tecnología de UNASUR, Colombia no es país miembro de UNASUR, nosotros sí, somos observadores, pero todos los demás 12 países del cono sur están ahí metidos en esta lógica, ahí con los Altos Estudios estamos trabajando todo una política de desarrollo de escenarios de estrategia de política pública para la integración desde la perspectiva de la academia, la investigación del desarrollo de proyectos en educación superior de ciencia y tecnología, estamos creando una Universidad latinoamericana ya llevamos varias pero se va a crear un polo de conocimientos único entre 12 países y proyectos de desarrollo de intercambio en movilidad de estudiantes académicos, proyectos conjuntos, etcétera, etcétera; grandes proyectos financiados por los estados Brasil, Argentina, Uruguay, Paraguay, Bolivia, Perú, Ecuador, en fin, Venezuela, menos Colombia y México tampoco, es observador nada más, pero el que observa no hace nada, es como estar atrás de los toros, no sabe lo que se siente estar enfrente de él en la realidad, es la realidad, es como una ver una película de Scarlett Johansson que tiene, pura imaginación, hay que hacer las cosas, intentarlas, hay que descubrir, entonces pusimos énfasis en la innovación y en el concepto de investigación prospectiva y estrategia desde el plano de la aplicación del contexto, del contexto de su aplicación y de la innovación en el desarrollo de alternativas del futuro, ese fue el enfoque.

Termino diciendo esta parte, esta segunda parte con lo siguiente, después de 10, 15 años de esta lógica en una reunión que tuvimos si no mal recuerdo en Medellín bajo el auspicio de una universidad privada que está en Medellín, ESUMER, ellos nos apoyaron un evento ahí. Con un grupo de colegas descubrimos en la discusión interna que teníamos de grupo de trabajo de la red latinoamericana de prospectiva y de las otras redes que ya se estaba formando, descubrimos que ya estábamos creando una escuela latinoamericana de prospectiva o sea que ya no 
estábamos imitando, ya no estábamos simplemente citando a Godet ya no estábamos trayendo lo que hace por ejemplo la experiencia Canadiense con Schwartz, etc., no, que ya teníamos una buena cantidad de expertos que tenían más de 10 años investigando sobre el tema que habían aplicado metodologías propias que habían creado herramientas propias y que habían pensado todo el tiempo en el terreno de la construcción de un futuro desde el presente por qué es la lógica de la prospectiva, la prospectiva no sirve para nada si estás especulando sobre el futuro, porque el futuro es indeterminado, impredecible pero sí se puede construir, sí se puede prever y se puede definir críticamente las variables por las cuales articuladamente pueden construir una estrategia y una política de acción transformadora que vaya claro con sus ajustes, sus devaluaciones y sus caminos vericuetos irse redefiniendo en el marco de la construcción de un futuro que deseamos.

En ese enfoque descubrimos que habríamos que poner una escuela de pensamiento propia, entonces decidimos este grupo construir la escuela latinoamericana de prospectiva, les estoy hablando de hace dos años y esto ya se concretó, por lo que prospectiva que no se concreta es como un acto fallido, esta escuela latinoamericana de prospectiva ya tiene cerca de unos 30 o 40 académicos de 12 o 15 países, todos expertos en el tema, el grupo de Guillermina va a estar presente, invitada para dar sus cursos, se va a dividir, ya ustedes pueden entrar en una primera aproximación de la página web, pero nos ha costado mucho trabajo, tanto construir la currícula, la perspectiva original, hacer el enfoque que nosotros queremos darle para formar prospectivistas latinoamericanos y no solamente, también a nivel global, por supuesto, el conocimiento no tiene límites, pero si desde un enfoque, intereses particulares, entonces aquí ya está un grupo de Uruguay, un grupo de Perú, de Paraguay, de Argentina, de Brasil, de Colombia, estamos ya con un convenio con la UNAD, la Universidad a Distancia de Colombia también donde tienen también una especie de especialidad y una Maestría obviamente con Mojica, en Ecuador con el Instituto de Altos Estudios del Gobierno del Ecuador, con la Universidad San Marcos en Perú, que también tiene una maestría que se les medio ha caído, pero ahí va y en México también con un grupo también de colegas muy muy importante, en Cuba, en Costa Rica y así, estamos ahorita, nos tomó tiempo por lo siguiente, uno porque vamos a comenzar con una especialidad en técnicas y métodos de la prospectiva, este va a ser digamos, la base sobre la cual todo el mundo quien ingrese a la ELAP, así se llama, Escuela Latinoamericana de Prospectiva tiene que tener, tiene que contar, si no tiene una base sólida teórico metodológica y técnica de la prospectiva pues no tiene las herramientas necesarias para hacer proyectos de investigación y de ahí acumulativamente los créditos para hacer una estructura flexible y en línea. 
Todo va a ser en línea, va a ser a distancia, o sea ustedes lo pueden tomar desde su casas, formarse desde ahí en maestría y doctorado, esto nos ha llevado un poquito de tiempo, porque Guillermina lo sabrá, porque la Secretaría de Educación Pública, porque nosotros vamos a otorgar el título para el registro del Plan de Estudios de la especialidad, la maestría y el doctorado, no saben, cómo se tarda, cuando el burócrata, sobre todo, no tiene ni idea de lo que está leyendo, imagínense ustedes que les digamos allí este, balance de los estudios prospectivos en el mundo, veamos, de una de las asignaturas o sea toda la controversia, el debate mundial sobre las diferentes escuelas de pensamiento y su enfoque, no tienen ni idea, hay que irles a explicar, bueno nos hemos tardado un poquito, pero ya está a punto de tener el registro oficial de validez para lograr el título desde México, pero la colaboración, el intercambio bajo convenios estamos haciéndolo con 10, 12 países y ya comenzamos, arrancamos con Colombia, ojalá podamos tener algún nivel de intercambio académico, estudiantil, de cursos, etc., con el Externado y también con Javier Medina en la Universidad del Valle también hemos conversado sobre el asunto, él tiene conocimiento de esto porque él también tiene una serie de cursos, vamos a comenzar con cursos sueltos, una especialidad y quienes vayan acumulando los créditos necesarios van a entrar sobre proyectos de investigación en áreas tan distintas como agua, educación, microelectrónica, biotecnología, nanotecnología, o administración, estrategias y política pública, ejercicio gobierno en la perspectiva del futuro, el área no nos interesa, lo que nos interesa es desarrollar estrategias y visiones de futuro hasta el nivel de doctorado, a ese nivel tanto maestría como doctorado, en un futuro muy próximo vamos a ofrecer bajo convenios por ejemplo con el Externado la posibilidad de hacer titulaciones conjuntas, titulaciones duales, triples, cuádruples, en fin sin ningún problema o cuando la legislación nos lo permita, por ejemplo, hay países donde la universidad es la única que emite el título profesional respectivo en pregrado o en posgrado por ejemplo la Universidad Autónoma de Santo Domingo, la UASD tiene por ley constitucional ser la única que otorga títulos y grados, entonces República Dominicana se ve imposibilitada de que otra institución otorgue el título o grado.

Entonces ahí lo que vamos a hacer es, que los muchachos o las muchachas que deseen tener cursos, siempre se les va a acreditar como lo hacen en Europa, con un diploma suplementario, o sea la persona sale de economista pero nosotros podemos otorgar que la persona hizo 50 créditos sustentados en la legislación mexicana y otorgamos su diploma de en qué hizo y cuál fue su esfuerzo y pues obviamente entrega los dos papeles cuando quiere tener una opción laboral donde quiere manifestar o quiere demostrar que tiene herramientas para el diseño de estrategias 
de política pública o intervención en el futuro del cambio de las instituciones o del país o de las comunidades, de las empresas o de donde ustedes quieran, eso va poder también hacerse, por ejemplo, en la Universidad de la República de Uruguay donde es la Subsecretaría de Educación Superior también la única que otorga títulos de grados o sea la Universidad de la República, o sea está la Secretaría de Educación Pública que es para primaria, secundaria, y la Universidad de la República de Uruguay es la que otorga y dirige la política pública de educación superior, entonces con ellos también hacemos un convenio para hacer este tipo de equivalencias, lo estamos haciendo con FLACSO Cuba, con FLACSO Montevideo, con Lidia Garrido, entonces ahí vamos a entrar en convenios. FLACSO es más flexible porque no es una institución nacional, es una institución latinoamericana, FLACSO y CLACSO, ese es digamos la experiencia que hemos construido, ya tenemos una escuela latinoamericana, digamos no vamos a tener el monopolio de la escuela, simplemente va a ser el espacio donde nosotros organizamos académicamente para que en esa escuela se exprese quien quiera, de forma flexible, ustedes organizan un curso, lo metemos en línea, ya tenemos toda la plataforma para hacer interacciones hasta de un millón de personas simultáneamente, ¿ustedes ubican Miami el servidor potente?, ya tenernos la estructura, tenemos la planta académica, tenemos el nombre, las alianzas, necesitamos construir más alianzas, por supuesto, porque esta escuela la queremos hacer extensiva como espacio académico de formación en este caso en línea, va a ver una modalidad semipresencial: aquellos donde existan grupos específicos que quieran que nosotros acreditemos algunos cursos con nuestros académicos que están registrados en nuestra planta docente, pues lo solicitan y mandamos al profesor y hay una interacción tanto en línea como en situ, presencial, entonces vamos a tener una actividad semipresencial, pero siempre la plataforma va a estar vigente y activa; bueno finalmente, y para cerrar, ¿qué pensamos que puede ocurrir en el futuro?, hacia el 2030, 2035 vamos a tener una serie de acontecimientos ya verificables que son tendencias y constructos, posicionamientos que están en marcha, tres, cuatro, hasta donde me alcance a cubrirlos:

Primera tendencia, en el 2030, 2035 ocurre el fin de lo que llamamos el cambio o la transformación drástica de la estructura poblacional mundial, ustedes saben que a partir del 2000 y hasta el 2030 está ocurriendo un fenómeno demográfico que le hemos llamado el umbral demográfico internacional, que está consistiendo en que una treintena de países están alcanzando el nivel de envejecimiento más alto que han tenido en su historia, Japón, partes de China, partes de Asia, partes de Europa, sobre todo el norte de Europa, Finlandia, Suecia, Noruega, etc., Alemania, en fin, parte de Estados Unidos y Canadá están en esa situación. 
Esta condición demográfica está implicando el desarrollo de una política pública de transformación del conjunto de sus estructuras productivas y de servicios, cuando tengan el 70\%,72\%,75\% en algunos países de mayores de 70 años, habrá un cambio radical, es decir son personas que no laboran y que tendrán que utilizar todo tipo de servicios frente a una población que no crece, por más estímulos económicos que les dan, en Suecia por ejemplo, si tienes más de dos niños te triplican tu salario, imagínate, un mexicano por allá, un colombiano, hacen patria en Suecia, ayudan al desarrollo, pero las Suecas están teniendo hijos hasta los 40 o 45 o hasta los 50 años y un hijo.

En Japón ahorita tiene el más alto grado de complejidad, por su propio sistema: uno, que el niño de los 0 a los 6 años es propiedad de la familia; pero de los 6 años en adelante cuando ingresa a la escuela se convierte en ciudadano y ya no le pertenece a la familia, pertenece al Estado, y el Estado le tiene que garantizar comida, educación, trabajo, ropa, etc., y futuro laboral, todo, haga lo que haga, sea un técnico en refrigeración hasta un físico nuclear, y las familias ya no, entonces empiezan a acumular porque ganan mucho y la ley de herencia es estricta en Japón, que no permite heredar, por ejemplo yo tengo un amigo que su mamá vive en una casa muy bonita tradicional Japonesa en Tokio, ella le buscaba heredar a mi amigo, un investigador de Monbusho, el Ministerio de Educación en Ciencia Tecnología y Deporte de Japón, le buscaba heredar la casita tradicional, bueno, él tenía que pagársela al Estado a una tasa superior para mantenerla, entonces, se la queda el Estado, todos los bienes que ustedes acumulan no los pueden heredar más que en cierta parte.

La parte monetaria o dependiendo de la familia o de su situación económica por supuesto se hace un estudio, en fin, pero por lo regular, la gran parte se la queda el Estado, entonces iqué hacen los Japoneses?, pues gastar como locos, cuando ustedes va a Harajuku, ¿quién conoce Japón? (responden) ¿pero si han ido a Japón, ¿conocen Ginza?, Ginza es una calle donde están todas las firmas, entre Ginza y Harajuku que es una calle enorme, son casi $5 \mathrm{~km}$, en donde están los principales almacenes, donde lo que uno compra por \$100 en otra zona de Japón, allá cuesta $\$ 1,000$, son centros comerciales y tiendas de cadenas como Chanel, etc., pero los Japoneses van a Ginza a comprar para llevar la bolsa y decir "esto me lo compré en Ginza y me gasté como 10,000 dólares entre zapatos y dos bolsas", "bravo, porque estás gastando" y los únicos que ven en los aeropuertos comprando Chanel o relojes Rolex son Japoneses y Chinos y Coreanos y Taiwaneses.

Todos son estados autoritarios que cuando te mueres te quitan la herencia, entonces esto da pauta, de hecho a que el mercado interno sea brutal, a una 
capacidad de consumo impresionante, estas cosas han hecho que el sistema educativo y ciudadano sea muy sólido, sea muy muy sólido, muy integrado, muy cooperativo, muy articulado a diferencia de nosotros. No que es desarticulado; yo lo que estoy pensando es cómo ahorrar para dejarle algo a mi hijo porque la circunstancia está tan gruesa... Pero bueno, el escenario mundial: una primera tendencia que se rompe en el 203002035 es ésta, el envejecimiento y versus el triple de formación de jóvenes de entre 15 hasta 45 años en América Latina, nunca en la vida, en la historia de nuestros países vamos a tener tal cantidad de jóvenes como los estamos teniendo ahorita, se llama el boom demográfico o el bono demográfico, ¿saben cuánto llevamos desaprovechándolo?, desde finales de los 90 y principios de los 2000. Lo hemos desperdiciado tanto que se ha formado un sector poblacional nuevo que no conocíamos nosotros en nuestra generación antes de los 90 que se llaman "ni-nis" que están en toda América Latina, cuando puedan échenle un ojo a la estadística del último informe de esta revista, esta es una revista mexicana, se llama de la A a la $Z$, vienen los datos de un estudio de la CEPAL sobre los ni-nis en América Latina, en todos lados hay ni-nis, aquí en el estudio está Colombia, los ni-nis son jóvenes que no estudian, ni trabajan, frente a gobiernos que tampoco ni gobiernan, ni hacen nada, tenemos gobiernos ni nis, jóvenes ni nis, este es un fenómeno brutal.

Pero hay un dato que es terrible, que contradice, por ejemplo, los indicadores del PNUD para fines del desarrollo del futuro, que es que el incremento en el desarrollo de la mujer ya que contribuye directamente al desarrollo porque evita crecimiento poblacional, genera mayor estabilidad económica en el hogar, genera mayor cultura en los vástagos, genera una mayor capacidad de bilingüismo y estabilidad y paz, el asunto es que el 63\% de los ni-nis en América Latina son mujeres. Es un dato terrible, o sea son menos los jóvenes hombres que andan en la calle deambulando sin trabajar ni hacer nada, que dependen de algunos ingresos escasos de la familia, o roban, o andan en la droga, se prostituyen o lo que ustedes quieran, pero son más las mujeres.

Entonces tenemos en esta variable demográfica una situación en los países desarrollados que les va a costar transformar sus estructuras sociales y productivas, reforma rápida en 10, 15 años, tienen que readecuar hospitales, escuelas, servicios de seguridad, servicios de mantenimiento de población adulta, de diversión, de cultura, de entretenimiento, etc., y tienen que redefinir las políticas de atracción, de migración, sobre todo y particularmente, no de una migración como ya la tuvimos en la época del capitalismo digamos depredador, que fue a abrir las fronteras de los países desarrollados a mano de obra barata, ya no, eso ya 
se acabó, porque la mano de obra barata ya está siendo sustituida por máquinas. Ahora lo que se va a dar es el fenómeno de lo que se llama en inglés, el fenómeno migratorio, knowmads, los "nómadas del conocimiento", o sea personas con alto nivel de conocimiento, capacidades, doctorados, etc. que son los que va a migrar, y de dónde van a migrar más, pues de los países donde hay más jóvenes, siempre y cuando tengan el conocimiento respectivo, sino pues van a ser de cualquier doctorado; los agarran de donde sea, la nacionalidad no importa, ya muchos somos nómadas, andamos para todos lados.

Es un fenómeno para América Latina, si nosotros no incrementamos las capacidades internas endógenas de desarrollo de plataformas en ciencia y tecnología y transformamos las instituciones de educación superior, esos (personas con alto nivel de conocimiento, capacidades, doctorados, etc.) se nos van a ir, la migración inteligente, la migración del conocimiento y nos vamos a quedar con los trabajadores más pobres, pero pagados con una precariedad laboral y con una estructura productiva y social no adecuada al mundo del conocimiento. No tenemos universidades que impacten en nanotecnología, biotecnología, ayer en una examen doctoral yo les dije la cifra y se quedaron de a seis, entre 1910 que se fundó esta universidad, la UNAM, hasta el año 1940 el 65\% del total de sus estudiantes, ¿saben en qué carrera estaban?, en Derecho, igual que en Colombia o en otros países versus Argentina.

En Argentina eran psicólogos la gran mayoría de los egresados, en los años 50 y 60 casi abarcaban la gran mayoría de la matrícula y no están tan locos los argentinos para tener tantos psicólogos, tienen casi un psicólogo per cápita, nosotros aquí tenemos un abogado per cápita, ya si se quieren divorciar tienes 15 abogados apoyándote y si te sale mal, sale muy caro, después tuvimos de los años 60's a los 70's la generación de los Administradores, llenamos las universidades de Administradores por todos lados, de marketing, de contabilidad, de Administración de empresas, economistas de empresa, de gestión, etc., y aquí también, en esta facultad en donde estamos es la que ha tenido el mayor crecimiento per cápita de los últimos 20 o 30 años en la UNAM y de todo el país, ahora se diversificó un poquito; hay 6 carreras en América Latina que concentran del 70 al 80\% del total: de los estudiantes de Comunicación, Ciencias Sociales y Administrativas, Comercio y Administración, Medicina, Ingeniería Civil y Medicina General, Derecho por supuesto, que tienen la mayoría.

Y sobre Nanotecnología, Biotecnología, Láser, Robótica, Telecomunicaciones, ¿saben cuántas tenemos?, puedo contar esas carreras, o sea licenciaturas, maestrías y doctorados con una mano, poquitísimos, no contribuimos a los que son las 
áreas de frontera del conocimiento, qué hacemos entonces, pues lo exportamos, lo exportamos porque aún tenemos un computador azteca, Brasil tiene, Paraguay tiene, Colombia tiene computadoras, tiene lap top's, aquí en México se empezó a hacer una lap top más o menos, se cae a cada rato el software pero bueno sale barata y es mexicana, hay que apoyar lo que produce nuestro país. Todo lo demás es Toshiba o Sony y software ni se diga, solo hay dos, quedados en un lugar que se llama Sídney..., Apple y Microsoft y ahora hay más desarrollos especializados por supuesto, pero como los grandes, ese es una tendencia.

Segunda tendencia, importantísima del cambio mundial en el futuro, de aquí al 2030, 2035 la modificación en la toma de decisiones, en términos de la producción del conocimiento y la transferencia de tecnologías de Estados Unidos, Europa, Asia, va a ser dominante Asia, en el 2025, 2030, 2035 olvídense de tener empresas que tomen decisiones estructurales estratégicas fundamentales en Europa o en Estados Unidos. No, van a ser producidas en China, en Japón, en Taiwan, en Singapur y una parte le va a tocar a Australia y Nueva Zelanda, o sea toda el Asia que llamamos Pacific Rim (NOTA: Titanes del Pacífico, como es el nombre de la película de ciencia ficción dirigida por Guillermo del Toro), el Área del Pacífico y esto implica decisiones en términos de cosas muy importantes, por ejemplo células de alteración en enzimas o alteración microbiológica de productos que pueden constituir armas letales si se prolifera en términos de biosociedad.

Les cuento rápido una anécdota, yo fui Secretario de Educación Pública en el Distrito Federal, ahí me tocó lo del virus HlNl que una era una mutación de gripe normal, Un niño de San José California que vive en Perote Veracruz, se trasladó de San José California al aeropuerto del Distrito Federal y entre el aeropuerto del Distrito Federal, se fue a la terminal de autobuses y de la terminal de autobuses se fue a Perote, contaminó a 3,600 personas en ese rato.

Creamos un comité científico porque de repente comenzaron a llegar casos que no eran gripa, tenían algún factor gripal pero no exactamente y empezaron a morirse porque no había vacuna, no se comprendía el fenómeno de la mutación biológica que estaba ocurriendo en el gen, a la semana teníamos 36,000 casos, hay un Coreano que trabaja en Berkeley que hizo una mutación ya del H1N13 que le prohibieron continuar con el proyecto en Estados Unidos, que es brutal, metes unas gotas a un caño o a un canal de agua potable y olvídate, riesgo a la población ya no digamos los gases venenosos, estamos hablando de algo más, de lo que fue el argumento de Bush para invadir Irak, que nunca encontró ningún arma masiva, pero bueno así se arman las decisiones... Pero entonces los principales laboratorios se están trasladando en Asia, todo lo que es la nube del internet 3.2 
y lo que le llamamos hoy en día la sustitución del internet que se llama Big Data, el macro Dato para 2035, va a ser la base sobre la cual se va a organizar todo el sistema informático del mundo, sus hijos, sus nietos les van a decir "ioye papá que era eso de internet eh, cómo que compraban en tiendas, iban a la tienda a adquirir los productos, iban a un hospital, no usaban procedimientos genómicos?".

Se llama Big Data, porque maneja datos relacionados con sistemas georeferenciados determinados fundamentalmente por las empresas financieras de seguros y que van a relacionar salud, seguridad, comportamiento de tu biogénesis, de tu ADN y de tus enfermedades, y obviamente la reproducción de las personas a través de las cuales, van a empezar a tener obviamente consecuencias directas en el entretenimiento, la cultura, la recreación y las relaciones personales; y la toma de decisiones se está haciendo allá. ¿Ya vieron la película Her? véanla, es un personaje que tiene un dispositivo, un chícharo que le llamamos nosotros, todo se comunica con un chícharo, todo es por la voz, no hay mouse, no hay sistemas operativos de Microsofia, todo es por la vía de la visualización del aparato con la voz, el personaje se enamora de un sistema, el sistema le hace tres preguntas: una ¿en qué trabajas?, hacía cartas de amor o de relaciones, dos ¿cómo te sientes y por qué compraste este aparato?, bueno, pues me sentía solo y quiero hablar con alguien y la tercera pregunta le dice la computadora, está si me la tienes que contestar muy bien ¿cuál era la relación con tu madre?, le estaba comenzando a decir, "bueno yo con mi mamá hemos tenido serias dificultades", muchas gracias y entra el sistema operativo y le da voz, calidez, preguntas, todo, todo, todo, configurado tal como él lo quiere, su mujer diría; bueno pues se enamora locamente con el aparato, hacen el amor, se van a la nieve, luego van al mar, anda con ella todo el tiempo, se van a los juegos de Six Flags y todas esas cosas y ella también puede ver con un aparato que tiene su lector, puede ver lo que él está viendo, el problema viene cuando le cae el veinte como decimos aquí, dice "oye, con ¿cuántos andas?" yo sé que tú eres un sistema operativo pero ¿con cuántos tienes relaciones simultáneas?, dijo, ahorita con 35,029, el hombre dijo "yo sé que tu obviamente tienes que operar con muchas gentes para fines de negocios, no con quién estás enamorada como conmigo" y el software dice, nada más con 416.

¿Quién ha tenido 400 relaciones simultáneas de aquí?, yo sé que los colombianos son prolíferos y andan de moda las colombianas, como dicen allá, Chévere, ¿Quién ha tenido bueno 350?, ya vi que algunos se quedan callados como diciendo, le digo o no le digo, bueno, 50 simultáneamente, en Medellín, en Cali, en México, oye estos prospectivistas están muy conservadores eh, no van a poder vivir el futuro, bueno dos, tres, cuatro, ya está más cercano a la realidad verdad, pero véanla. 
Tercera tendencia, la redefinición de las decisiones en términos del valor social del conocimiento vinculado a los nuevos sistemas financieros, biotecnológicos, genómicos, microelectrónicos, del Big Data, de la sustitución de los softwares y del internet, viene en Asia, somos parte del Pacífico Asiático, si no tenemos una visión estratégica donde Colombia, México, incluso acabo de firmar un tratado bastante formal diría yo para no decir otra cosa, el de Asia Pacífico; tenemos que mirar hacia allá eh, muy en serio, porque nuestra alianza siempre ha sido con los Estados Unidos y Europa.

El autor que más me fascina de Colombia es William Ospina, tiene una visión cultísima de qué es la gran cultura occidental versus nuestra gran cultura precolombina, ¿si han leído a Ursúa no, o En busca de Bolívar?, fuerte corrector de estilo de García Márquez, imagínense, ni más, ni menos, el que le corregía los textos a Gabriel era William, es un tipazo, es el escritor, el más importante, de los más importantes que tenemos en América Latina porque no es tan grande y escribe sensacional, yo todo lo que sale de él, lo leo. Pero ahora tenemos que empezar a estudiar las investigaciones, los resultados y proyectos, las estrategias, qué centros estratégicos se están conformando, cómo se están desarrollando las inversiones, cómo están trasladándose los sistemas financieros, empresariales, de gestión, de organización, en Asia, porque Estados Unidos va a tener un colapso según Joseph Stiglitz y Paul Krugman, dos premios Nobel, de acuerdo con ellos después de la burbuja, del estallamiento de la burbuja inmobiliaria que ocurrió en 2009-2011 que fue brutal, se acabaron las 15 empresas de inmobiliarias especulativas más grandes, comenzando por Lehman Brothers. Los autores están previendo que entre el 2015 y el 2016 viene el estallamiento de la burbuja crediticia, del sistema crediticio internacional, porque tiene una deuda imparable, es catastrófica, nadie la puede pagar, ni por todo lo que vendan en todos sus activos, nada, entonces va a estallar la burbuja crediticia, saben qué implica, la desaparición por lo menos de los tres o de los cuatro grandes consorcios financieros crediticios internacionales, el Banco Mundial, el Fondo Monetario Internacional, el Banco Interamericano de Desarrollo y otros cuatro o cinco europeos que por ahí andan graves, porque es del crédito mundial, no del crédito de nosotros que yo creo que pagamos hasta por tarjeta mil pesos al mes, consumimos a crédito como dicen en Colombia de tres, cuatro o cinco cuotas, no, aquí se trata del crédito internacional, viene la explosión de la burbuja crediticia internacional.

Cuarta tendencia, la crisis del sistema financiero internacional crediticio con la caída de la economía financiera de por lo menos del euro, que ya está medio así tambaleándose con la crisis en Grecia, en Irlanda, en España, en Portugal, en 
Italia, Francia, el único que se salva y hasta ganaron un copa, fue Alemania y por eso la ganaron y no fue penal; ahí para mí la ideal era Brasil con Colombia, para mí eso hubiera sido una serie de mundial, Colombia iba muy bien, iba mejor México.

Y última tendencia, la redefinición del orden de la división internacional del conocimiento, porque hoy es el valor agregado fundamentado de las economías en donde llega, de acuerdo con los analistas, no sé si ustedes los han leído, los de las ondas largas, Cristopher Freeman, Giovanni Dosi, Carlota Pérez, está de moda, es bastante reconocida toda la teoría política de los ciclos económicos, de acuerdo con éste enfoque teórico metodológico; léanse ustedes The Capital, el último libro que va a salir, está brutal, es una cosa así de 700 páginas, así se llama El Capital, igual que el de Marx; Griffin ya fundó Cultura Económica, lo está traduciendo en español, pero va a salir hasta el año que entra, lo pueden ustedes leer en inglés o en francés, en su idioma original, como ustedes quieran, él asegura que la redefinición del orden mundial se va, primero viene por la sobre producción, los países más desarrollados tradicionales están entrando a una fase de extrema sobreproducción, las crisis económicas no se derivan de las escasez, se derivan de la sobreproducción, de que hay más de lo que tú puedes consumir y es extremo, o sea, nunca había habido menos millonarios en el mundo y más población pobre, antes la riqueza estaba más repartida, el Shah de Irán, la Princesa de Filipinas o la Primera Dama de Filipinas que tenía 600 pares de zapatos, no, ahora hay 15 grandes hombres y mujeres más ricos del mundo.

Una concentración extremadamente brutal frente a una extensión de la pobreza como nunca antes la habíamos visto, o sea hay niveles de pobreza y de miseria insospechados, el último informe de la UNESCO sobre educación para todos Education for all, encontró que en lugar de que en el 2010 se hayan logrado las metas de dar educación primaria de seis años a todos, se creó una franja en el mundo peor educada o más deseducada, desescolarizada, mayor de la que había en el siglo pasado, terrible, y esto ocurre en niveles de pobreza en muchos países, incluyendo los gringos o los países desarrollados. En Estados Unidos acabo de estar en un visita reciente a la UC, la Universidad de California y es impresionante la cantidad de gente que vive en la calle, digo aquí si tenemos chavos banda que o ni nis que duermen ahí, pero no en tal cantidad, es impresionante, uno sale con el estómago verdaderamente contraído, pero miles eh, cientos de miles...

Esta redefinición del orden mundial del valor de los conocimientos va a crear de acuerdo con estos analistas de los ciclos largos, una transmultipolaridad, es decir se fortalecen los BRICS con tres, cuatro naciones más, yo espero que estemos ahí nosotros, en este segmento de los mercados emergentes, por lo menos en una temporada. 
Corea aparece como un país, como un super país per se Corea del Sur, sólo China obviamente alcanza su mayor poderío, se redefine todo el orden de los Balcanes bajo el liderazgo de Turquía, Corea aparece como el líder y ya no Japón, el conflicto Chino Soviético, ex Soviético o Coreano no ha tenido solución, por lo menos en el marco de estos próximos 15, 20 años, necesitaríamos estar en una situación de paz mundial para resolver y tener mecanismos de resolución de conflictos internacionales de esa magnitud, igual Palestina e Israel se van a destrozar hasta el último bebé que encuentren de un lado y otro, o sea, pero esta zona la redefine Turquía y no Europa.

Europa no alcanza a terminar a culminar su proceso de unificación, es muy probable que en 5 o 7 años se vuelvan a las monedas locales y haya solo un grupo comandado por el Banco Europeo que mantiene el euro como moneda de referencia de la transacción de divisas como lo es para muchos de nuestros países el dólar, sólo decimos, bueno si cuesta $\$ 30,000$, pero cuánto es en dólares, y hacíamos constantemente lo que son modelos de referencia, igual va a quedar más o menos en ese esquema, y América Latina diría William Ospina dice la región del futuro, ahorita ya llevamos un proceso de integración impresionante en 12 economías de América Latina, no estamos ahí nosotros por nuestra cercanía y nuestra visión neoliberal con Estados Unidos, pero después yo espero que nos demos cuenta ahora, que podemos tener gente inteligente en el gobierno, gente que sepa que los jóvenes, la educación, la ciencia y la tecnología, las universidades, el bienestar, el empleo son factores mucho más importantes que andar vendiendo al país por todos lados. Muchas gracias 


\section{LA WFS MÉXICO, EL GRUPO CORAZA Y LA PROSPECTIVA: JULIO MILLÁN BOJALIL CON LA INTRODUCCIÓN DE OMAR MÉRIDA}

Nota: Omar Mérida es el director de la World Future Society Capítulo Mexicano, él hace la introducción explicando lo que es el Capítulo y cómo está vinculado a Consultores Internacionales S.C. empresa asociada de Coraza Corporación Azteca S.A. de C.V entrelazando la visión prospectiva. Aparecerá también la inquietud de los participantes que hicieron varias preguntas frente a las acciones de consultoría.

a World Future Society Capítulo Mexicano organiza periódicamente desayunos que comparte con funcionarios para que puedan conocer también las inquietudes que nosotros tenemos sobre el futuro para que podamos obtener la información que nos están pasando de primera mano y nosotros poder dar nuestra retroalimentación al respecto. Estas reuniones son con el fin de poder hacer lo más amenos posibles los análisis, es decir, lo más francas, serias; no se abren a la prensa, son unas reuniones muy privadas, muy enfocadas, pero la verdad bastante productivas.

Han estado con nosotros entre otras personalidades, Jorge Castañeda que es el canciller de México o Manuel Mondragón que fue Secretario de seguridad del Distrito Federal y Director de la Policía Federal aquí en México, de ésta manera buscamos abarcar de todos los temas posibles: seguridad, economía; reuniones con académicos.

A principios de éste mes nos reunimos con la directora del Instituto Politécnico Nacional, fue una reunión bastante interesante, con el fin de poder ver que se estaba haciendo en cuanto a educación tecnológica aquí en México, también este año nos reunimos con el director del CONACYT que es nuestro Consejo Nacional de Ciencia Tecnología e Innovación y con el ingeniero Cuauhtémoc Cárdenas 
que ha sido candidato a la presidencia del país, un líder moral de la izquierda política en México, también participamos en Congresos internacionales, en 2008 el Capítulo Mexicano tuvo el honor de llevar al licenciado Enrique Peña Nieto, en ese entonces gobernador del Estado de México, y al doctor Luis Videgaray, a la reunión de la World Future Society de Capitulo Mexicano.

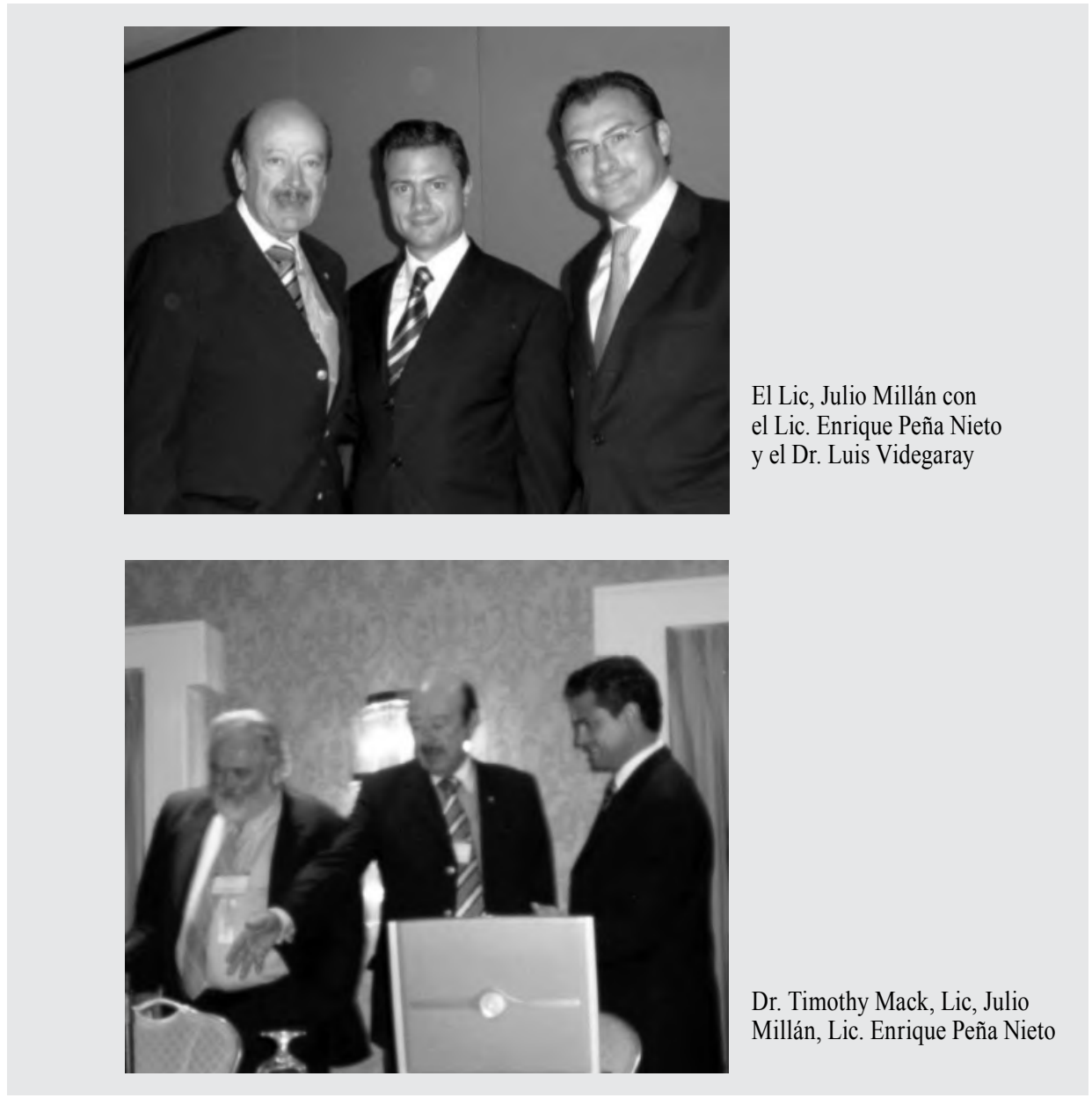

Peña Nieto estaba interesado en conocer un poco más acerca de los estudios del futuro, de los estudios que se hacen, él también, inclusive, colaboró con un comentario para el de State of the Future publicación del Millenium Project. Son algunos de éstos tomadores de decisiones a los que buscamos acercarnos, influen- 
ciarlos sobre la importancia de pensar en el futuro, aquí está el Lic. Julio Millán con el Lic. Enrique Peña Nieto y con Tim Mack hasta hace poco, presidente de la World Future Society a nivel internacional, también realizamos nosotros aquí congresos de talla internacional, se han realizado dos, uno en 2003 y otro en 2010, en éstos encuentros en los cuáles se realizan una serie de conferencias con las cuales poder traer a prospectivistas, a escritores, académicos internacionales, con el fin de que ellos nos pudieran dar su visión sobre el futuro.

En el 2010 se organizó en colaboración de la UNAM con la ANUIES que es la Asociación Nacional de Universidades e Instituciones de Educación Superior y la OCDE, entre otros, entonces son estos eventos ya un poco ya más grandes en los cuales no son tan reconocidos como quisiéramos porque es necesario conseguir todos los recursos, logística y todo, pero en próximos años estamos tratando ya de trabajar en el siguiente evento ya a 5 años del último que fue en el 2010, con gusto los mantendremos informados. Este congreso que fue en el 2013 Los futuros del mundo, ese estuvo un poco más enfocado acerca de escenarios y de futuros en un aspecto más internacional, más global, mientras que el de 2010, Encuentro en México, estuvo más enfocado hacia cuál podría ser el futuro de México en diferentes áreas.

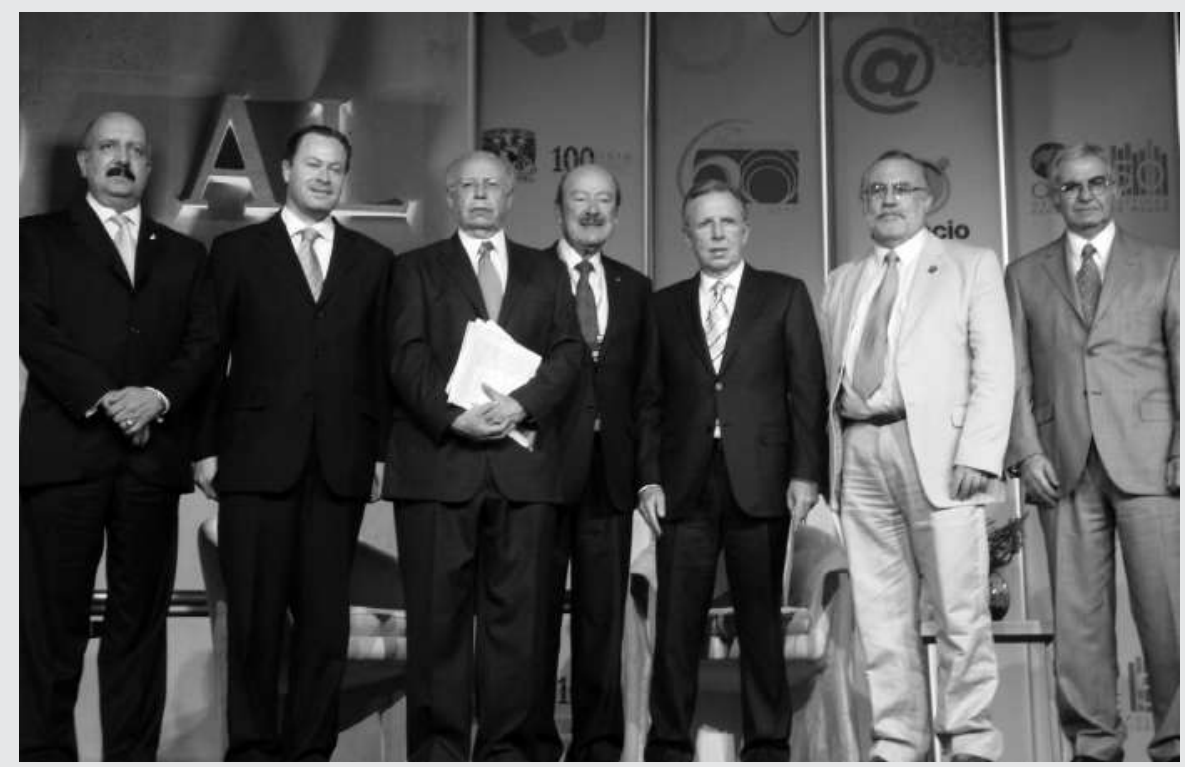

Encuentro México 2010, Construyendo Futuros. 
Estas son algunas de las publicaciones con las cuales trabajamos, The Futurist que es la revista pionera en estudios del futuro a nivel internacional editada por la World Future Society, las publicaciones que aquí se han trabajado a nivel mensual el Capítulo Mexicano, elabora un boletín digital que se llama Futureando que es una recopilación de noticias sobre el futuro, recomendaciones de lecturas y donde también los socios de nuestra organización pueden participar con algún documento, con algún reportaje, también ahí es donde hemos comenzado a editar, estamos en una pausa por cuestiones presupuestales, The Futurist en español, que es la revista que con todo gusto les estamos compartiendo.

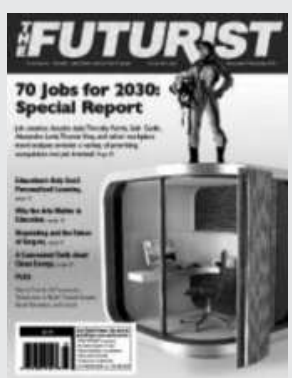

The Futurist, revista bimensual publicada por la World Future Society

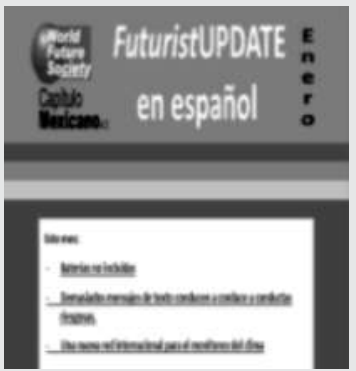

Futurist UpDate en español, publicación mensual

Futureando, publicación mensual.

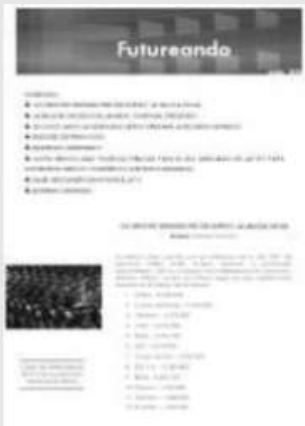


La forma de operar es a través de socios con diferentes cuotas dependiendo los beneficios que deseen obtener, es como le damos operación y mantenimiento a toda nuestra organización, pero sobre todo, lo que buscamos con los socios es integrar un buen networking para que ellos nos puedan de alguna manera acercar con otras personas que también tienen interés en el futuro, ya sean académicos empresarios y sobre todo estas oportunidades de networking funcionan bastante bien en las reuniones temáticas.

Como mencionaba, una de las cuestiones que buscamos a través de nuestra red de socios es precisamente tener una cuestión bastante diversificada, precisamente para apoyar estas cuestiones de networking, actualmente entre nuestros socios existen desde instituciones de gobierno como por ejemplo es BANCOMEXT que es un banco de desarrollo para empresas que desean exportar, así como también instituciones académicas como la propia UNAM o también a nivel personal, como desde académicos, empresarios, algunas empresas dedicadas por ejemplo TABS es uno de nuestros principales socios, es una empresa dedicada a la aplicación de tubería, plásticos. Entonces se trata, de alguna manera, tener esta cuestión muy diversificada de socios, lo cual nos ayuda a nosotros a conocer inquietudes de diferentes sectores académicos, empresariales y dentro de unos, por ejemplo del sector empresarial, inquietudes en diferentes áreas, entonces también con ellos, ésta diversidad puede ser muy rica al momento de aportar opiniones durante las reuniones de enfoque como en las reuniones internacionales.

El fundador, el presidente, el Licenciado Julio Millán, quien además fundó y preside Coraza Corporaciones Azteca, Consultores Internacionales, es licenciado en economía por la UnAM; el doctor Antonio Concheiro es vicepresidente a quien me parece conocieron el día de ayer; a quien ya conocen, la Doctora Guillermina Baena; el químico Luis Manuel Guerra, él es uno de los académicos más importantes en cuanto al tema de sustentabilidad de agua aquí en México; la licenciada Mayra Herrera, ella dirige un centro dedicado a cuestiones de prospectiva en el Instituto de Investigaciones Sociales; el Licenciado Guillermo Prieto Fortún, él es uno de los empresarios más importantes aquí en nuestro país, además fue gobernador del Banco de México. Entonces es, digamos de esta manera, mostrar la diversidad un poco que buscamos aquí dentro de nuestros socios, para enriquecer la construcción del futuro desde diferentes ámbitos.

Ésta es actualmente nuestra mesa directiva, el Sr. Julio Millán nuestro presidente, vicepresidente el Dr. Antonio Alonso Concheiro, tesorero el Lic. Guillermo Prieto Fortún y nuestros vocales la Lic. Mayra Herrera y el Lic. Luis Manuel Guerra; químico Luis Manuel Guerra, aquí se ilustra la diversidad que tenemos 
de pensadores en prospectiva, empresarios, entonces esto es lo que buscamos integrar, a lo que me refería de división holística aquí en la World Future Society Capítulo Mexicano para tener todo tipo de opiniones, de retroalimentación sobre el futuro en diferentes áreas, ésta es la organización diríamos con la cual buscamos impulsar la prospectiva aquí en México.

Me faltó comentarles que por ejemplo semanalmente entre nuestras publicaciones contamos con una cápsula de radio, precisamente los miércoles a las 8 de la mañana con el Doctor Leonardo Curzio en un sitio que se llama Enfoque, la presenta el Licenciado Julio Millán y va un poco con temas del futuro y también en el último año se han estado generando participaciones de la World Future Society en este caso a cargo de un servidor para Forbes México, precisamente con cuestiones de futuro enfocadas hacia negocio o empresa, así es más o menos cuando nos cargamos un poco y precisamente como menciona el Doctor a lo mejor para el complemento viene muy bien para el lado social que se desarrolla en la Federación.

A continuación les voy a presentar un poco sobre lo que es Coraza Corporación Azteca y principalmente en especial, dónde estamos, que es Consultores Internacionales, aquí en Consultores Internacionales somos una empresa pionera en ofrecer servicios de Consultoría Económica, fue fundada en 1969, lo que tenemos nosotros es experiencia con futuro, y toda vez fue porque cuando fue fundada por el Lic. Julio Millán hace ya 45 años, él lo que buscaba ofrecer de diferente en cuanto a servicios de consultoría era precisamente comenzar a ayudar a las empresas, a gobiernos, a instituciones no sólo a resolver un tema coyuntural, un tema de ahora, sino a ¿cómo te puedo a ti a ayudarte a posicionarte dentro de los próximos 5, 10, 20 o 30 años?, entonces digamos en éste caso, Consultores Internacionales sí es una empresa de consultoría pionera en cuanto a temas de prospectiva, que hoy en día existen varias pero si les podemos ahora sí que asegurar que fuimos los primeros.

Principalmente nos desarrollamos dentro de tres áreas, que es lo que llamamos Inteligencia Prospectiva, Inteligencia Estratégica Competitiva y un Centro de desarrollo para PYMES, quedamos que Inteligencia prospectiva es el desarrollo de escenarios a mediano y largo plazo que permiten la toma de decisiones acertadas ante cada situación, que me dan certidumbre en el futuro, analizamos mega tendencias, su cambio en el mundo y letanías que impactan a la empresa de la industria, un mecanismo que permite tomar previsiones y domesticar la incertidumbre, elemento clave para adaptarse a los cambios, Consultores Internacionales es pionero en ésta metodología que ha coadyuvado al crecimiento de numerosas instituciones, gobiernos y organizaciones mediante la exploración de los futuros posibles, probables y deseables. 
Después del proceso les voy mostrar un ejemplo, tanto para el sector privado como para el sector público de éstos estudios de inteligencia prospectiva que hemos desarrollado, nada más rápido, antes de todo les puedo mostrar que sobre todo trabajamos mucho sobre todo en los últimos años con cámaras, con sectores empresariales con los cuáles pues por darles un ejemplo muy breve, recientemente trabajamos con la Cámara de perfumería y de cosméticos, y de productos de aseo, entonces con ellos empezamos a ver cuáles pueden ser los cambios de los próximos 15, 25 y 50 años en cuanto a las tendencias tecnológicas, sociales, en cuanto a consumo, haciendo cortes por generación de edad, acciones que están moviendo los consumidores, esto es la inteligencia de la que partimos de ahora hacia delante.

Es algo que los clientes aquí en México les interesa mucho: el presente, porque una visión empresarial si uno nada más está viendo el hoy y el mañana realmente las cosas no funcionan, es parte de un valor agregado que nosotros damos a los clientes y donde la prospectiva nos ha ayudado precisamente para poder brindarles estas soluciones, éstos servicios que ofrecemos son agendas de competitividad prospectiva, mapas de futuro, estudios de gran visión, sistemas de gestión prospectiva, creación y manejo de escenarios, ordenamiento territorial prospectivo, escenarios políticos de seguridad nacional, modelos prospectivos de mercado y posicionamiento, y los beneficios que esto tiene son visualizar el futuro de su empresa y del sector ante eventos de trascendencia, escenarios a mediano y largo plazo, poder prevenir amenazas y oportunidades, contar con una gestión prospectiva de su negocio, brindar valor agregado a la empresa mediante información de vanguardia, además de permitirles reducir la incertidumbre, el tema de incertidumbre en el sector empresarial es clave, aquí varios administradores de empresas no me van dejar mentir, cuando tú puedes salir un poco y ver cómo vienen los cambios, cómo te pueden afectar, qué es mucho más fácil tomar decisiones y sobre todo, en algunos casos, brindar, poder brindar ésta certidumbre a tu junta directiva, a tus accionistas.

Aquí en México estos productos nos han dado mucho valor en los últimos dos años, México está pasando por un proceso transformador como no se había visto en mucho tiempo, en cuanto a reformas laborales, energéticas, reformas fiscales, entonces nosotros hemos trabajado mucho en los últimos dos años con varias empresas, sectores para decirles cómo les pueden afectar estos cambios, qué puede venir más adelante y qué es lo que pueden hacer; así, también, trabajando con gobiernos para ayudarles a hacer sus mapas del futuro, no sólo es decir, bueno estoy sacando mi reforma energética sino, ¿qué quieres hacer con esa reforma energética, cómo te ves en los próximos 10, 15 o 20 años? y aquí es donde nuevamente se ve un poco ésta sinergia que tiene Consultores con la World Future Society. 
Hace un año tuvimos en nuestras unidades temáticas al senador David Penchyna, es el presidente de la Comisión de Energía de nuestro senado, de ahí, de esa Comisión nace esta Reforma Energética que el país está viviendo, entonces fue una buena reunión para precisamente intercambiar ideas y conocer qué es lo que estaba sucediendo, no sólo aquí en México, sino en el mundo, aquí es donde se ve esta sinergia entre cómo se retroalimenta Consultores Internacionales S.C. con la World Future Society.

Dentro de lo que llamo Estrategia Competitiva en la era del siglo XXI obliga a tomar decisiones en menor tiempo y considerando un mayor número de variables, la Inteligencia Estratégica Competitiva es una herramienta clave para definir e implementar estrategias y acciones a través del seguimiento, análisis e integración de valora a la información, éste proceso integral permite a sectores empresas, instituciones, adaptarse a los cambios de corto y largo plazo mediante la construcción de agendas competitivas que comprenden la integración de las agendas locales y globales de valor y con ellos generar hacia mercado interno en pro de su crecimiento, algunos de los clientes con los que lo hemos desarrollado esto es PEMEX, CONCAMIN, COCA COLA, CONACYT, CANACERO (la cámara nacional del acero), AEROMEXICO, CANIPEC que es la que les mencionaba de perfumería y cosméticos, es digamos que con éstos sectores, desde gobierno, cámaras, con las empresas privadas con las cuáles buscamos ayudarles a desarrollarse, ¿qué es lo que necesitas tú para posicionarte? Inteligencia en prospectiva te ayuda con los escenarios, la agenda competitiva es, esto es lo que puede suceder, ¿qué acciones tienes que tomar, en qué plazo e identificando qué actores, así como tu mapa de ruta para poder afrontar estos cambios?

Las agendas de acciones en particular para cadenas productivas generan competitividad, también desarrollamos un sistema que se llama Can-bus, son observatorios en cuanto a tendencias, noticias y demás paras sectores, servicios de información estratégica, planeación estratégica, evaluación y desempeño y estudios sectoriales.

Los beneficios: les permite contar con un sistema de alerta temprana, contar con información estratégica sectorial, alineamiento institucional y empresarial, atracción de inversiones, sistema de seguimiento puntual de indicadores y tomar decisiones de manera más dinámica e integral, con éstas acciones es como se busca realmente toda esta decisión holística que les comenté, se abarcan a todos los actores que participan, identifico que para esto tal vez se necesita cambiar tal ley o tal norma, pero para ello qué actores requiero, bueno desde los actores que van de gobierno hasta tal vez, diputados, Congreso de la Unión, qué comisiones 
en particular, todo este mapa de ruta con las indicaciones que se tienen a futuro es lo que da un valor agregado a nuestros clientes porque, porque si ellos llegan con un diputado y le dicen, necesito cambiar ésta ley, ¿por qué?, bueno porque si no lo haces, en tres años puede ser que haya sucedido esto, esto y esto, o hayamos dejado de generar competitividad en esto, esto y esto, y en diez ya nos retrasamos por esto, esto y esto. Entonces cuando uno llega con ésta visión de futuro, sobre todo con los actores gubernamentales que se les plantea tal cual les dije, es que si no hacemos esto ahorita, ya nos atrasamos diez años en esto y esto tiene un costo social, en empleos en esto, entonces es mucho más fácil generar ésta sensibilidad y esta toma de decisiones.

En el Centro de Desarrollo PYMES hemos diseñado diversas metodologías y herramientas al alcance de la mediana y pequeña empresa que permite profesionalizar y modernizar procesos para una rápida y visible mejora en productividad, utilidades y permanencias de mercados, contamos con un grupo de consultores especializados PYME para atender las necesidades de las empresas, aquí sí en un trabajo ya un poco más de consultoría en el sentido tradicional de acercarse a ver cuáles son las necesidades de las PYMES; sin embargo, un valor agregado que les estamos dando últimamente es ayudarles a participar con varias PYMES digamos se juntan 50 empresas, para buscar ayudarles a internacionalizarse o poder acceder conjuntamente a un fondo, o bien ayudarles a que se vuelvan proveedores para grandes empresas tractoras que vienen, en ese aspecto, una situación con la que estamos trabajando últimamente en cuanto a internacionalización es aprovechar otra de las áreas que tenemos aquí, que se ha desarrollado aquí en Coraza y es digamos nuestra vinculación con una región tan dinámica como lo es Asia Pacífico.

En éste caso el Lic. Julio Millán fue de los primeros empresarios en abrir el mercado Chino con México, firmó el primer acuerdo en colaboración en 1981 y también cuenta con una condecoración del emperador de Japón, entonces nosotros aquí también en Consultores, tenemos una responsabilidad. Contamos con el secretariado del Consejo Asesor de Negocios de APEC, es un consejo privado de empresas para APEC, los cuáles se reúnen varias veces al año para proponer soluciones para gobierno, y aquí hemos encontrado muchas similitudes, ha sido muy interesante, como ustedes sabrán, muchos de éstos países del Asia Pacífico cuentan con una visión muy interesante de futuro, por ejemplo Singapur, que cuenta con su propia maqueta de cómo se ve a los próximos 30, 40, 50 años, ha sido también otro lado donde uno encuentra similitudes con éste pensamiento prospectivo y que también ayuda a entender por qué a lo mejor éstas naciones están avanzando tanto en los últimos años. 
En estos términos ofrecemos diagnóstico modular, procesos de mercado, desarrollo de planes de negocios, implementación de sistemas de gestión, procesos de transacción que es lo que mencionaba, procesos de encadenamiento, agendas competitivas, investigación, desarrollo e innovación, los beneficios que les permiten a las PYMES tener una mayor permanencia en el mercado, lo cual es el principal problema que ellos enfrentan, potenciar las áreas de oportunidad, detectar nichos de mercado, mejorar la calidad e incremento de su productividad y materializar proyectos específicos como internacionalización e integración de áreas productivas con varios grupos de empresas.

En Consultores Internacionales hemos desarrollado modelos económicos que constituyen para su empresa herramientas de vanguardia para la toma de decisiones, muestran el comportamiento futuro de variables económicas de la población y del consumidor ante la construcción de diferentes escenarios, contamos con un Centro de información tanto de fuentes políticas como temáticas que permite contar con un amplio acervo documental, así como sustanciales bases de datos, el caso de nuestro Centro de información es una herramienta muy importante para nosotros, estamos suscritos a muchas bases de información, además de contar con memorias estadísticas del Banco de México, algunos de los años 30's, 40's para ayudar precisamente a compilar cómo se pueden ir haciendo, cómo se han comportado, cómo han visto las variables económicas u otras variables desde hace varios años.

Éstos son algunos de los modelos que hemos desarrollado, contamos con lo que llamamos el modelo económico Tlacaélel, cada tres meses elaboramos en conjunto con el Banco de México nuestras propias proyecciones económicas que van desde el crecimiento del PIB, remesas, importaciones y exportaciones a través de observar todas las variables, contamos también con lo que llamamos el modelo Baco, para estimar el consumo de bebidas alcohólicas, una industria con la que hemos trabajado últimamente. Nosotros elaboramos un Índice de precios metropolitanos que es uno de los más activos en la ciudad de México, precisamente para medir los niveles de inflación en el Distrito Federal y área metropolitana, una publicación que sale cada martes en el periódico El Universal desde hace varios años, así como también con un servicio en información, en el caso de sus comentarios si ustedes gustan se pueden suscribir a él y lo reciben gratuitamente en su correo, lo mismo con el Índice metropolitano de precios.

Desde 1978, con el fin de ayudar a impulsar a las nuevas generaciones; Consultores Internacionales instituyó el premio nacional Tlacaélel de Consultoría Económica que ha premiado a las mejores tesis que se presentan a nivel nacional 
en Licenciatura en Economía de las diversas Instituciones de Educación Superior, alguno de los ganadores en el pasado, por ejemplo son el Doctor Agustín Carstens que es el actual gobernador del Banco de México y el Doctor José Antonio Meade que es el actual canciller de México.

Contamos con un área internacional que se llama Coraza Internacional la cual trabaja como county manager para representar empresas aquí, por ejemplo representamos a Peabody para la venta de carbón a la Comisión Federal de Electricidad, aquí aparece la World Future Society, que es una de las áreas con las cuáles tenemos la sinergia que se genera con el otro, así como también otras empresas de consultoría, algunas de consultoría política aquí en México.

Esto, digamos, es la empresa y como trabajamos un poco con prospectiva, les mostraremos los ejemplos de los proyectos que se han desarrollado, como le llamamos, de gran visión, donde se aplica metodología prospectiva, uno se hizo para una empresa comercial y otro se hizo para un gobierno.

En este caso es el resumen ejecutivo de un proyecto que se hizo en el año 2000 para Nestlé, en donde se ven presentes las prospectivas del mercado de cacao, café y leche en México al año 2025, lo que cruzamos con este valor fue primero la evolución demográfica, los cambios en los patrones culturales, las tendencias económicas, el análisis de las materias primas dentro de la disponibilidad y lo que es un escenario deseable con alta factibilidad para la industria.

Comenzamos por evaluar la población en México entre 0 y 4 años, entre 2000 al 2025, con el fin de poder analizar que, digamos, iba a ser lo que estos niños estaban haciendo hacia futuro como potenciales consumidores, y para el caso del café, y en este caso particularmente lo que tiene que ver con el consumo de leche, esto en el caso del cacao que fue importante que se dio entre el grupo entre niños de 5 a 14 años, nacidos entre 1995 y 2025, ello con el fin de ir identificando cual iba ser el tamaño de mercado disponible dentro de estos escenarios, así como también una cuestión en temas de edad laboral para el tema de la disponibilidad en acceso por la capacidad del poder de compras, en el caso para adultos mayores con los cuales aquí bueno, uno de los hallazgos dentro del trabajo es como se ha ido cambiando en la cuestión cultural en cuanto al café, que a lo mejor hace algunos años el doctor a cierta edad comenzaba ya a dejar de recomendarlo, cuestiones de estómago además y como con el paso de los años se ha visto que al contrario, que es mucho más recomendable y aquí en México, de hecho, hemos retomado este año este estudio, este trabajo ahora para nuestra Secretaría de Agricultura enfocado en café precisamente en decirles mira cómo ha cambiado los patrones culturales, al lado hoy en día estamos viendo códigos de ya meter en publicidad a 
niños consumiendo café toda vez que se está desmitificando todas las cuestiones que existían alrededor de esos y esto es una cuestión que se ve con los aspectos de los patrones culturales....

Por ejemplo en una población total creciente en cuestión de lácteos se observaba un aumento en cuanto a los requerimientos que nutricionales o inclusive una posible saturación de mercados de fórmulas para lactar más allá del año 2005 , si existió un menor crecimiento de la población infantil que haya implicado una reducción relativa en el consumo de leche, entonces son algunas de las cuestiones de analizar si subía o aumentaba la población cuál podía ser el impacto en este caso por producto, en este caso para los lácteos, en el caso de una evolución a la tercera edad, se iba a identificar una demanda de productos lácteos adecuados a los requerimientos nutricionales geriátricos los cuales en los últimos años han encontrado un importante nicho, un hallazgo curiosamente paralelo que encontramos al analizar esto fue empezar a recomendar a Nestlé, comenzar a embotellar agua en México porque se veía que ya empezaban todas las regulaciones con productos azucarados o con algunos productos que pueden ser no tan recomendados para la salud, uno de los principales hallazgos, paralelos curiosamente de este estudio fue la recomendación de Nestlé para empezar a embotellar y vender agua, para diversificar sus productos...

Cuestiones relativas al cambio de patrones de consumo o cuestiones poblacionales, alimentos sustitutos también, ahora sí que eso en general, todo lo que tiene que ver con sustitutos. Y en México, por ejemplo, en cuanto a las limitaciones en alimentos en productos chatarra o producto azucarado, precisamente porque ya los dulces tradicionales ya no pueden venderse a escuelas o cerca de escuelas pero los productos de amaranto o chía, sí.

Pregunta: ¿Es decir que desde el punto de vista digamos metodológico de las herramientas de prospectiva hay en esa primera parte que nos estás indicando, lo que ustedes hicieron metodológicamente es forjar una de esas 4 o 5 ejes que nos mostraste ahorita: evolución demográfica, patrones culturales, tendencias económicas, es que identificaron unas variables claves y a estas variables les formularon unas hipótesis, es lo que estoy viendo, es cierto, un poquito, la guía aplicado para el caso de Nestlé?.

Respuestas: Exactamente y ya con ello te desarrolla en acciones en concreto, por ejemplo diversifica tus productos, con esto o enfócate en esto.

Pregunta: ¿Aquí, de una vez, ustedes empezaron a hacer una especie de recomendaciones, decíamos con el análisis previo que estaban desarrollando? 
Respuestas: Exactamente, para el caso del café... Después de esto por eso Nestlé ha comenzado a implementar su programa, me parece que también lo tiene Colombia, el programa de Nescafé con el que trabaja con los agricultores.

Aquí comenzamos a ver un cambio en las decisiones de consumo alimentario pero es un esfuerzo de decisión de consumo por edad de población. Ya lo que en 2000 comenzaba toda la cuestión de consumo responsable, ya del consumidor responsable que ya... se fijan en la etiqueta de que si es reciclaje o reciclada, entonces ya es un elemento diferenciador y este proyecto fue del año 2000 cuando se empezaba a ver eso y fue como un poco analizar qué es lo que impacta más al momento de tomar una decisión para consumir por grupo de edad, y se cruzaba con lo anterior de cómo iba ser la evolución del grupo de edad, entonces ya también te permitió un poco enfocar más desde la presentación del producto o que es lo que quieres realmente vender del producto, aquí por ejemplo encontramos como había ido variando algunas cuestiones en cuanto al lado fuerte, les mencione que se empezó el control de agua embotellada, leche baja en grasa, arroz, y en el tema de café es curioso porque aquí en México es más el consumo de café instantáneo que de café de grano...

Aquí en México fue una de las políticas que se empezaban a impulsar porque desafortunadamente muchas familias preferían el consumo de refresco, antes que comprar un litro de leche, empezamos también a observar un poco cómo iba cambiando la cuestión de la cocina en el futuro, ya que van quedando un poco atrás cuestiones más tradicionales en cuanto a la manera de preparar alimentos.

Algo inmediato que encontramos fue que estábamos consumiendo una menor cantidad de café y leche entera líquida, mayores volúmenes de agua, leche desgrasada y bebidas refrescantes, aumento en el consumo de personas por refresco así como también en el aumento de consumo por refresco especialmente de cola, estos hallazgos que se elaboraban en el 2000.

Este año de hecho ha comenzado a caer el consumo por las medidas fiscales que le están poniendo en contra, entonces es interesante ver cómo era hace 15 años y como va a comenzar ahora, y entonces digamos de esta manera fueron las herramientas metodológicas que empleamos aquí en Consultores Internacionales, en este caso aplicadas para 4 productos para una empresa privada como fue Nestlé, analizando patrones de consumo, patrones culturales, evoluciones demográficas y también otras cuestiones que se comenzaban a analizar como una mayor regulación, con una mayor preocupación por el bienestar personal, de ahí que fue mucho que comenzó el aumento en el consumo de leche libre de grasa y otro tipo de leches, entonces de alguna manera es nuevamente esta visión 
holística que les comentamos, que aquí le damos mucha importancia para poder tener, ahora sí, la fotografía completa para poder presentar un trabajo de valor agregado al cliente y aquí donde se empiezan a encontrar unos productos digamos ganadores y perdedores a nivel de consumidor.

Esto fue parte de un estudio comercial que se hizo, ustedes comentaban cómo es que hemos trabajado para gobierno, esto fue para el estado de Veracruz, no sé si alguno de ustedes lo conoce, es el estado que está sobre el Golfo y este caso para el 2020, 2025. Aquí lo que buscábamos era brindar información básica sobre las tendencias y realidades que enfrentaba el estado de Veracruz en los próximos 25 años, intercambiar puntos de vista para la orientación de proyectos detonadores en la región y ofrecer herramientas que contribuirán a potenciar el desarrollo de la región.

Aquí en lo que nos enfocamos es lo que tiene que ver con equilibrio regional, crecimiento ecológico y desarrollo humano, tratar de identificar todas las variables alrededor que incidían en el desarrollo de este estado en los próximos 25 años a fin de potenciar su crecimiento económico y de darle un equilibrio, se revisó un análisis de tendencias y realidades, de retos y oportunidades y se programó una agenda de actividades.

Pregunta: ¿Las tres grandes variables que nombras allí: equilibrio regional, crecimiento ecológico y desarrollo humano fueron ya dadas por el marco de política del estado de Veracruz o cómo se llegan a que sumen esas tres bajo las cuales se va a desarrollar el ejercicio prospectivo?

Respuesta: Tiene que ver más con los diagnósticos mismos que recalendarizamos nosotros para nuestro cliente, y se cuenta con una comunicación escasa con el cliente pero digamos todo si viene de aquí para allá, estos son algunos de los indicadores que se proyectaban en cuanto población, el descenso de tasa de fecundidad, esperanza de vida, migración, tasa de crecimiento cultural y aumento de edad promedio, aquí comenzamos a ver un poco como comenzaba a ser el desarrollo humano destacando un poco el crecimiento de población que se comentaba, ya es una realidad de cómo se van ensanchando las pirámides poblacionales, aquí es donde vamos identificando algunos escenarios en cuanto al desarrollo humano, en un escenario optimista, objetivo para ver en donde podría caer y las acciones que se tendrían que llevar para cada uno.

Aquí en desarrollo humano se identificó que para el 2025, 1.8 millones equivalentes a 72 mil empleos anuales, aumentaron 50\% la cantidad de médicos y enfermeras, de viviendas, ellos tienen que ver cuáles eran las tendencias en cuanto a población, necesidades de las mismas y qué es lo que se tendrá que hacer 
para ir alcanzando sus diferentes escenarios así como también de los indicadores educativos todavía estaban, aun así van a estar lejos de alcanzar indicadores internacionales, aquí es un ejemplo de cómo se buscar enfocar, por muy optimista que seas es necesario que debas aterrizar y que siempre tengas una buena comparativa internacional.

Algunos de los retos eran transformar el alfabetismo funcional, impulsar la educación permanente, aumentar escolaridad promedio, lograr interés en las carreras del futuro, sistemas computacionales o en la tecnología, desarrollar estructuras de educación superior, etc., entonces digamos esos son todos los elementos que se fueron encontrando y analizando alrededor de lo que necesitaría el estado para potenciarse, para brindar un mejor desarrollo humano e impulsar su crecimiento económico hacia el año 2020, 2025.

Pregunta: Qué metodologías emplearon allí en ese caso específico y que es un trabajo digamos con el estado, qué grupos o qué actores ustedes empezaron a involucrar de cara para identificar cada uno de esos ejes, de esos retos, digamos hay un trabajo allí puntual de identificación de tendencias digamos es el trabajo o uno de los ejes de la firma consultora como tal y que sale de la firma consultora, pero también cómo es el proceso allí para llegar a que esos son los retos cuando se empieza a involucrar a los actores del estado, como qué metodologías emplearon allí con esos grupos?

\section{Aquí se incorpora el licenciado Julio Millán con sus comentarios:}

Respuesta: Mire, yo le voy a explicar por qué, pero antes de entrar el mecanismo en estos casos para llegar, esto es una síntesis casi de tipo cuantitativo, falta toda la parte cualitativa porque la parte cualitativa es la parte más conflictiva en cuanto a políticas públicas y todo esto.

Para llegar a todo este tipo de proyectos como es el caso de Veracruz, tenemos muchos estados, Michoacán, porque es un tema que todos decíamos que no lo debieron haber hecho pero lo hicieron, por eso tienen el problema que hoy tienen, el tiempo nos demostró que teníamos la razón mala desafortunadamente en ese sentido, se hace el mecanismo es el estado, el gobierno establece un equipo de tripulación de trabajo, este es intersecretarial, o sea precisamente dentro del gobernador que era Miguel Alemán, había un coordinador que era el jefe de gabinete, ese jefe de gabinete accedía a todos los secretarios de estado de educación, economía, transporte, todo este conjunto, esto se hacía con base en realizar proyectos de 
reuniones de enfoque, entonces se tenían que hacer reuniones de expertos por un lado y de funcionarios porque este proyecto tuvo la característica que así como se iba construyendo se iban tomando decisiones, o sea, no era un proyecto al final que actuar si no se iban direccionando las actividades del gobierno, de manera que por ejemplo en el área educativa había que darle una serie de cambios internos a las cuales si podía tener acceso el estado, uno de los ejemplos, icómo identificar que todos los maestros pusieran una materia sobre prospectiva, sobre el futuro, que incorporara en los niños el uso del tiempo, como se usaba racionalmente el tiempo?, entonces todo este proceso en términos operativos tenía que llegar a nivel y aparte de eso con estos grupos del gobierno y los expertos de fuera le daban la continuidad y con esto se podía hacer el siguiente paso, estos son resultados digamos paramétricos, lo más importante aquí en este caso es el elemento de la parametría, medición que se hacía.

Cosa que no se mide nunca se logra saber si se avanza, entonces precisamente las mediciones se hacían conforme a objetivos que eran realistas con los mismos objetivos de los mismos funcionarios, aquí no importa que el presidente o el gobernador decida, eso no tiene la menor importancia para un proyecto de prospectiva, eso no tiene importancia, es un lineamiento, es una direccionalidad, lo que cuenta es cuando el funcionario menor que entiende el tema y lo aplica en la comunidad, la clave de todos estos procesos es que la comunidad lo entienda y si lo entiende, entonces hay un respaldo que es la conciencia del círculo virtuoso, que se establecen estrategias políticas, objetivos, pero luego se fundamentan y bueno es lo que entonces que hace precisamente en espiral hacia arriba, este es el mecanismo que se sigue en todos, igual en el sector privado, por ejemplo para señalarlo, muchas empresas se han hecho aquí, muchísimas, por ejemplo todo el proyecto del país agrícola, de seguridad alimentaria se hizo aquí y todo esto se hace siempre.

Siempre la clave está en la coordinación y combinación con los actores, si no están los actores que van a ejecutar, no tiene razón de ser un proyecto de prospectiva, esto llévenselo ustedes como un mensaje, si ustedes lo llevan y sirve para el cajón, magnífico, si sirve para el ego político, magnifico, pero ese no tiene eficacia; la eficacia es cuando se aterriza, sea académico o muy bonito y satisface el sentido.

¿Por qué hemos tenido tanto éxito nosotros? porque somos de las muy pocas empresas que no nos quedamos a nivel descriptivo y académico sino vamos directamente, no vamos con el cliente, no vamos con el gobierno si no nos garantiza que se va a aterrizar el proyecto, no lo hacemos, nosotros hacemos un pre cálculo, es decir no tiene éxito aquí, usted lo quiere hacer digamos para tener un buen discurso político, no nos interesa, nos interesa cuando se aplique y ese es el resul- 
tado digamos, es la dinámica positiva que se ha generado, entonces a la pregunta de usted es: se hacen reuniones de expertos, se involucra a la sociedad sino, no tiene sustentabilidad, todos los proyectos de prospectiva sino se comunican a la sociedad, quedan truncos.

El área de salud es muy delicada, hay áreas de prioridades, hay áreas satisfechas en términos digamos académicos y hay áreas insatisfechas y en el futuro tiene uno que ver cuál va a ser la estructura de las necesidades, por eso se da la direccionalidad, los elementos matemáticos, econométricos y de cálculo y toda la información estadística es un punto de referencia pero de ahí salen las compulsiones que permiten el elemento, los elementos básicos de la disyunción.

Yo ofrezco disculpas por llegar tarde, vine de una junta ahora con Nacional Financiera, ahorita tengo que volver a salir pero quería venir yo, primero a saludar.

$\mathrm{P}=$ Una inquietud, respecto al caso colombiano en donde tenemos una política pública digamos de educación, es la política pública para todo el país, pero nosotros vamos a hacer el estudio territorial de un municipio, ese municipio tiene que sujetarse a la norma que está establecida como política pública nacional, si quiero hacer un estudio de prospectiva y tengo que modificar algunas cosas de digamos de utilizar el uso de prospectiva, que hay que modificar algunas cosas porque verdaderamente digamos el perfil académico no es para lo que esperaba. Esa cascada cómo se manejaría allá para que la política pública la podamos aplicar también allá.

$\mathrm{R}=$ Se maneja por decantamiento de pros y contras y cuáles son las prioridades, o sea en ese sentido una política pública federal que es lo que estás señalando que es la estatal no, o sea que es la de gobierno que tiene que irse decantando hasta llegar al nivel más bajo, hay lineamientos que no pueden ser cambiados, por lo tanto, esos lineamientos tienen que hacerse hasta donde se puede un ajuste a la caracterología del lugar pero hay áreas de oportunidad que se les da capacidad de darle un sentido al local, el caso de Veracruz, es un caso de estos, hay ciertas digamos tradiciones, condiciones educativas que en Veracruz no responden a todo el lineamiento federal y aquí si hay espacios para poder hacer que el sistema educativo estatal, o sea estoy hablando estatal, incluso municipal y de ajuste por la propia caracterología, la tradición de la gente, que incluso incluyen elementos de sanidad, de comida, de vestido, etc., entonces se direcciona, es como un árbol de dirección y que se acomoda a las ramas de acuerdo hasta donde pueda usted llegar, si se tiene que hacer y se puede hacer perfectamente

¿Cómo se logra la retroalimentación? a base de reuniones de enfoque que suben información hacia las autoridades, el problema es que cuando no hay reuniones 
de enfoque no sube la información, entonces se queda paralizada abajo y se queda como una instrucción sin movimiento, o sea estática. La clave es que suba la información, la gente siempre cree que la información baja y para que tenga dinámica requiere de subir, esa es una función de un prospectivista, que suba la información para tener dinámica.

Bueno, me da mucho gusto que estén ustedes aquí, esto ha sido una gran promoción de la Doctora Baena que es una de las grandes cerebros de nuestro país, Guillermina es una gente respetada en todos los sentidos, ¿no está su hija aquí con nosotros? sí, aquí está; qué bueno que estás aquí, hemos tenido que estar aquí toda esta semana, y que bueno que aunque sea un momentito estén aquí con nosotros en esta organización, una organización que es muy joven, apenas tiene 50 años, más o menos, pero yo creo que el enfoque que ustedes están tomando en todo lo que parte de educativo, en todo este reconocimiento de viaje, de reconocimiento prospectivo es muy importante, yo creo que uno de los temas básico es que en América Latina no existe desafortunadamente una cultura del no desperdicio, somos una cultura del desperdicio en la comida, el tiempo, somos una cultura del desperdicio y eso es lo que hace, que crea un concepto de distancias sustantivo entre la distribución de la riqueza y la distribución del bienestar, la distribución de la riqueza, la riqueza es riqueza, son bienes, pero la distribución del bienestar es otro, es la de que está incorporado seguridad, en salud, en tranquilidad de vida, en mantener tradiciones, ese es el concepto de la capacidad y la calidad de vida y en nuestros países somos muy cortoplacistas.

Entonces pensar en largo plazo, cuando está uno urgido de necesidades, de responder a carencias del pasado, cuando un país tiene muchas carencias del pasado, le cuesta mucho trabajo pensar en el futuro y eso es lo que hace esa dicotomía entre el pensar y actuar y por eso es tan importante convencer a las diferentes áreas de las tradiciones públicas y privadas, o sea, los actores tanto políticos, como fácticos, se requiere de convencerlos de tener por lo menos una direccionalidad, una direccionalidad que es, precisamente.

No hay un futuro, como ustedes saben, ustedes son estudiantes de esto, si no hay muchos futuros y hay muchos métodos para identificar las alternativas del futuro, hay un escenario apuesta que además tiene que ser dinámico y nunca sin usar un balón de bate, jamás puede hacer nada uno en el presente, o sea si no sabe a donde uno quiere llegar, el presente no existe, es simplemente un fenómeno de vida pero no es un fenómeno de creatividad, son dos cosas diferentes, uno puede vivir pero hay que crear su propia vida, yo siempre digo y es un tema que usamos, que el futuro no se inventa, el futuro no está predeterminado si no se construye y tenemos que construirlo. 
Entonces yo creo que uno de los temas centrales es que si existen grupos de gente de inteligencia incorporados en diferentes áreas del pensamiento en un país que tenga el concepto de futuro; esas son semillas que ayudan al cambio, o sea hay que entenderse que los que hablamos del futuro somos raros, si verdad, yo porque perdí el pelo hace muchos años, yo quedé raro pero la verdad es que somos raros y a veces nos confunden, nos confunden, consideran digamos que hacemos magia, no, como futurólogos y entonces se combina como adivinos, no, o sea como que tuviéramos una bola de cristal que pudiéramos nosotros predecir el futuro de una manera sistémica. No hay manera de esto, tenemos que nosotros ser semillas para convencer que la mejor manera de recrear un concepto en este mundo tan dispar y en un mundo con tantas carencias este concepto se llama disminuir la incertidumbre.

Cuando uno tiene un objetivo de mediano y largo plazo lo que uno crea es un sentido de disminuir la incertidumbre, porque de esa manera es como uno puede usar racionalmente los recursos ante un país que tiene la desventaja de que todo es un desperdicio, la capacidad de tener un objetivo a largo plazo genera una disminución de incertidumbre y eso genera una capacidad de usar mejor los recursos materiales e intelectuales, o sea es una dinámica digamos positiva, es un círculo virtuoso el que nosotros creamos en las conciencias de las gentes, después de que habla una gente con nosotros y podemos sentarnos a hablar de prospectiva y largo plazo, si no logramos que cambie sus parámetros de pensamiento nosotros perdemos, pero siempre si le dejamos la semilla, lo ayudamos.

Cada prospectivista puede ayudar al individuo, como puede ayudar a su comunidad, es cuestión de hacerlo expansivo, el cambio no se da digamos de arriba para abajo, se da de abajo para arriba en el pensamiento de las gente, entonces se tiene que crear este mecanismo virtuoso y en los países como los nuestros pues es muy importante empujarlo, en cualquier sector, entonces cualquier aspecto se puede pensar y se puede ver a mediano y largo plazo y si nosotros le damos a la gente como en el caso de los, digamos, macros, los que hacemos macros pues eso vale mucho y ahora, afortunadamente. Si yo les dijera a ustedes, nosotros empezamos con los proyectos nacionales de desarrollo en 1982, o sea somos países, yo digo que somos países adolescentes.

Colombia es un país adolescente, México es un país adolescente, o sea los países apenas tenemos un plan sexenal desde 1982, estamos iniciando el proceso cuando hay países que tienen objetivos de largo plazo desde hace más de 100, 150, 200 años, bueno otros países desde hace mucho más, por qué, porque la gente que construye esto tiene la mente hecha así y nosotros no tenemos mucha 
gente que tenga la mente hecha hacia el largo plazo, no la tenemos, entonces si logramos ir metiendo esto y sembrando una semilla en muchas áreas podemos hacer que los países tengan un cambio de mediano y largo plazo, entonces nosotros insistimos mucho en esto y uno de los mecanismos que me parece excelente es el libro de Es tu futuro... hazlo tuyo, o sea, el objetivo personal, yo me imagino que ya lo tienen, ese ustedes dirían pues es personal, que fracturado, de qué sirve el proyecto personal, pues sirve básicamente de detonador del cambio colectivo, no tiene ninguna lógica el pensar que el cambio colectivo se hace por arte de magia, alguien tiene que direccionarlo, alguien tiene que motivarlo y entre más gente logremos que tenga los objetivos personales y que lo entiendan, eso hace que se expanda el mecanismo de seguridad.

Nosotros somos los que estamos en prospectiva y yo espero que ustedes estén muchos años, somos detonadores de cambio, si no llevan esto como un mensaje es muy difícil y ya lo habíamos visto, como una habilidad.

Toda gente que estudia prospectiva y que hace proyectos de largo plazo son detonadores de cambio, y con esa vocación, porque no es solo un elemento solo de profesión eh, ustedes dicen bueno es que mi profesión, si no tienen vocación, no la hacen y van a tener que aplicar un concepto que yo uso mucho, espero que se acuerden de eso, el éxito es la suma de fracasos sin perder entusiasmo, el éxito es una serie de fracasos sin perder el entusiasmo y lo uso como un mecanismo.

A veces hablo con una gente, hago un proyecto que no funciona pero no pierdo el entusiasmo, finalmente tenemos éxito, como dicen del bateo, el que corre al bateo no es tan malo pero cuando uno no pierde el entusiasmo, de manera que yo si les diría que los prospectivistas son factores de cambio, tienen que hacer, crear, agentes de cambio y algo que funciona y que a nosotros creo que nos ha ayudado mucho aquí en esta organización es pensar en duro, pensar en duro, qué significa eso, pensarlo y pensarlo, nosotros como lo que usamos en inglés se dice las wild cards que me imagino que ustedes las conocen, pensarlo y pensarlo, lo que creemos que no podría suceder, lo que son simbologías digamos anticipadas, ya vimos una simbología anticipada y decimos esto puede suceder y pensarlo y pensarlo, imagino que ustedes conocen el libro de John L. Petersen Out of the Blue: Wild Cards and Other Big Future Surprises How to Anticipate and Respond to Profound Change, yo les sugiero que ese es un instrumento de un prospectivista fundamental, pensando y pensando, porque eso emite fundamentar y direccionar los riesgos y si uno los direcciona, conoce como salvarlos. El más vulnerable es el que no conoce los riesgos, el conocer un problema es el 50\% de solución, porque si creo que ustedes se llevan eso, ahora nosotros tenemos, obviamente y con eso 
termino, ya por fortuna en México en muchas empresas donde muchos hablan de prospectivistas pero la verdad, de hacer realmente prospectiva profesional, seria...

Hay muchos charlatanes, demasiados que han destruido muchas veces el mercado y lo han prostituido, esto es una realidad, pero también tenemos muy buenas gentes que tienen muy buen nivel, ustedes estuvieron con Alonso, es magnífico, con Antonio Alonso Concheiro, escribimos él y yo, coordinamos un libro que se llama México 2030. Nuevo siglo, nuevo país, yo patrociné ese libro, nosotros patrocinamos, para que tengan una idea isaben quiénes lo patrocinamos?, tres empresas, las cuales eran: Carlos Slim, un señor que conocen algunos de ustedes, pero lo patrocinamos porque el siempre piensa en el futuro; lo patrocinó nuestra empresa; y otra empresa que era Bufete Industrial.

Lo editó una editora en México muy famosa en América Latina que se llama Fondo de Cultura Económica, entonces nosotros le pedimos a Alonso Concheiro que nos ayudara técnicamente también, entonces vino con nosotros y coordinamos ese libro, uno de los libros que más me gustó coordinar porque hoy, después de las fechas, hemos comprobado la direccionalidad que habíamos planteado, eso fue una cosa de coordinación, no es un libro digamos de conclusiones prospectivistas pero esto es lo que nosotros tenemos que hacer, o sea nosotros tenemos que desarrollar conceptos que vayan a darle fuerza precisamente a que haya mucha gente que hable de esto. A mí no me importa que haya 100 competidores, al contrario, bienvenidos, bienvenida sea la competencia, eso nos hace cada día mejor, sí pero una competencia leal y una competencia no destructiva, es lo que siempre buscamos.

Pregunta: ¿Entonces se trabaja en equipo, de grupos interdisciplinarios que manejan mucho la prospectiva, cómo buscar esa dinámica completa, que aporten las interdisciplinas, cómo lo han logrado aplicar ustedes?

Respuesta: A base de un perfil de y un catálogo de expertos de base de nosotros, el sistema interdisciplinario primero lo manejamos primero como un fundamento, nosotros tenemos una base digamos fija de expertos pero la estructura de lo que se llama outsorcing de apoyos exógenos es como diez veces más grande en diferentes sectores y entonces se hace una precalificación de los que trabajan con nosotros, de manera que tenemos perfiles en todos los sentidos de experiencia y los vamos ajustando, algunos, muchos de ellos incluso que ahorita trabajaron con nosotros de forma part time, hoy tienen sus propios despachos, cosa que nosotros ayudamos mucho, pero digamos, es expansivo y en ese sentido lo que pasa es que la capacidad de una empresa de sostenerse es ser modernizada internamente, siempre estarse modernizando. O sea es diferente ser maduro a ser viejo, nosotros somos 
maduros, pero no viejos que es diferente, bueno incluso el tema de la organización vieron cuál era experiencia con futuro, y eso le ha dado a la organización, alguno de ustedes que ponga sus servicios, en donde quiera, en Colombia o donde sea, póngale también experiencia en futuro.

Terminaría diciéndoles, no hay que desanimarse, van a existir una serie de fracasos sin perder el entusiasmo, se van a encontrar con muchos problemas para muchas cosas.

La clave está en el chip del pensamiento, si se logra eso funciona muy bien, yo estuve ahora en la reunión de la Sociedad Mundial del Futuro en una de las reuniones que me pareció muy bonita que se llama conscience 1 y conscience 2 y luego cosmic beat que me pareció muy importante, y con eso me despediría, si no tienen alguna otra pregunta.

Esta parte quería terminarla diciendo, a mí me llama la atención un concepto que se manejó ahí, que no se si ustedes ya lo manejan, el tamaño del cerebro del humano no ha cambiado, sigue siendo el mismo, no ha tenido manipulación genética hasta ahora, no ha tenido manipulación genética, entonces el concepto humano, si yo trajera un cavernario de los cavernícolas, lo cambiara de vestido, le pusiera un traje, corbata, lo arreglara, lo afeitara y lo pondría en Wall Street, caminaría igual, sería igual que cualquier otro, seríamos los mismos, somos los mismos, las especies humanas obviamente nos hemos adaptado igual que todo y la evolución no existe, desde mi punto de vista es la lucha contra la teoría de Darwin porque no ha habido en el proceso del conocimiento humano, ninguna especie que haya cambiado, se ha adaptado pero no ha cambiado.

El humano no ha cambiado, sigue siendo, qué es lo que ha hecho, ¿qué ha hecho? lo que ha hecho es la conciencia humana, el primer proceso de conciencia 1. es toda la historia de la humanidad y el hombre hasta llegar la revolución agrícola industrial, ese es el primer punto de inflexión, ahí cambia sustantivamente el conocimiento, no la persona sino el conocimiento; 2 . que es de ahí al desarrollo tecnológico e informático, 3. La que esperamos: es el hombre cósmico, la persona cósmica es la que viene y le da el salto cuántico a la comunidad, nosotros somos parte de un sistema planetario, entonces a mí me llama mucho la atención como el proceso del conocimiento es el hombre, o sea lo que es el cerebro humano, es el único que ha creado su propia evolución, ¿cómo?, incorporando conocimientos, herramientas, conocimiento, hasta llegar a un sistema exponencial, estamos, en los últimos 50 años ha sido exponencial, lo que no habíamos pensado y acumulado en 20 mil años lo hemos hecho en un segundo de tiempo y el tiempo cósmico es un instante, entonces crecimos y estamos al punto cuántico del cambio, tan 
es así que es la primera vez que estamos viendo cómo pueden manipularse los cambios realmente en el ADN, cómo se pueden cambiar las genéticas, el hombre ya empezó a crear una influencia en cambio, de genéticas en los propios animales, en las propias plantas ya comenzó a cambiar la genética, esta manipulación viene desde siempre, siempre ha sido así.

Hace años si yo le hubiera dicho a alguien ¿oye tú crees que puedes clonar un ser vivo? me hubieran dicho está usted loco, mal de la cabeza. Hoy se puede clonar, si yo le dijera bueno y sin llegar a los elementos ni religiosos ni filosóficos ni nada explícame, todos tenemos lo cristianos como dice que fue la creación en la Biblia, muy fácil ¿fue Adán, muy fácil y cómo nació Eva, de la costilla, fue una clonación o no? hace años me hubieran dicho a mí no me lo hubieran preguntado, cómo vas a creer eso, pues era imposible, hoy me hace reflexionar el conocimiento que está confirmando muchas cosas que son fundamentales y de un punto de referencia en el mundo, nosotros no somos de la nada, somos una semilla en el cosmos.

Entonces estas reuniones que tuvimos en la Sociedad Mundial del Futuro le muestran a uno la velocidad del cambio del concepto y algo que me gustaría que yo creo que podría ser muy interesante para ustedes el día de mañana es, lean un libro que se llama: Las 5 regiones, se los sugiero, ustedes van a decir, ilas cinco regiones? El mundo distribuido en cinco regiones, bueno pues simplemente para qué, pues si son los continentes o qué son, no, son 5 regiones de la capacidad humana y cada región se repite en todas partes del mundo, hay ciertas capacidades que se repiten en todas las partes del mundo, no importa la parte étnica, el lugar geográfico y cuál es el objetivo de cada una de estas regiones, yo les sugiero que lo lean, eso les va a dar a ustedes la idea de la universalidad del pensamiento, entonces cuando uno está en esas cosas, como ustedes vinieron aquí. Yo lo que hago cuando voy a estas reuniones yo le llamo lo que es un refresh, que es un refrescar la memoria y conectar las neuronas, el mundo está en un cambio total y a ustedes les va a tocar ya ser parte del cambio de lo que se llama el hombre, el humano cósmico, y eso ya estamos a punto de, estamos muy cerca, y ustedes, muchos de ustedes lo van a vivir.

Sé que ustedes se van el viernes o sábado, ojalá que les haya sido interesante, que les haya sido viable y agradable la estancia en México, así que ustedes han sido muy bienvenidos, muy bien organizados aquí por el grupo de Guillermina, muy bien, y ya en lo individual, cuando quieran venir estamos con los brazos abiertos. Muchas gracias 
SEGUNDA PARTE

VISIONES GENERALES 


\section{PROSPECTIVA EN MÉXICO: SERGIO MONTEO OIVARES}

1 futuro es múltiple... Hablamos de cumplir el destino, el destino decía que nos íbamos de aquí a la una de la tarde, pero apenas vamos a iniciar, pero bueno, lo que ocurre es que esto es algo que ya ustedes se lo saben de memoria, no existe ningún destino, no existe algún futuro, pueden hacerse pronósticos pero no necesariamente se cumplen. Vamos a ver, hemos estado durante la mañana platicando sobre la prospectiva y ustedes están estudiando prospectiva, por lo que platicaré con ustedes no se trata exactamente de cuestiones teóricas que ya vieron, sino partamos de que ya conocen cosas, la Doctora Baena a quien agradezco la invitación, ya que ha sido muy gentil conmigo por invitarme a estos eventos, fue quien dispuso el tema de prospectiva en México; después, al ver la visita que ustedes están haciendo me dije: es que realmente los cinco días van a hablar de la prospectiva en México, entonces iqué les doy?, finalmente iqué quiero platicar con ustedes?: dos aspectos, un punto de vista personal de cómo está la prospectiva en México, y segundo transmitir, compartir con ustedes cómo hacemos, cómo hago las cosas.

Ustedes han estado escuchando a distintas personas y sí, es realmente un logro que hayan reunido a todos ellos, no es fácil, estamos todos aquí en México, pero no recuerdo algún evento en donde hayamos estado todos. Como han escuchado hay distintos puntos de vista, distintas formas de hacer las cosas, lo que menos tenemos, es una escuela mexicana de prospectiva, lo que tenemos, yo creo, es un propósito en común, tenemos valores compartidos con respecto a la prospectiva, pero no necesariamente todos pensamos igual. 


\section{LA PROSPECTIVA EN MÉXICO}

En el desarrollo de la prospectiva en México, de forma muy general, creo que hay fuerzas que la están impulsando, ya escucharon cómo nació la prospectiva en México, tiene muchos años, desde principios de los setentas, pero bueno, todavía con altibajos, no son altibajos muy importantes, también quiero reconocer que en Colombia llevan el liderazgo actual, hay que decirlo, están haciendo muy bien las cosas, nos tratan muy bien por allá, ¿tenemos celos de que vayamos atrasados?, no. Lo único que todavía yo no puedo creer es, como pueden vivir sin tortillas.

En la siguiente imagen, hago un acercamiento general de la situación actual de la prospectiva en México:
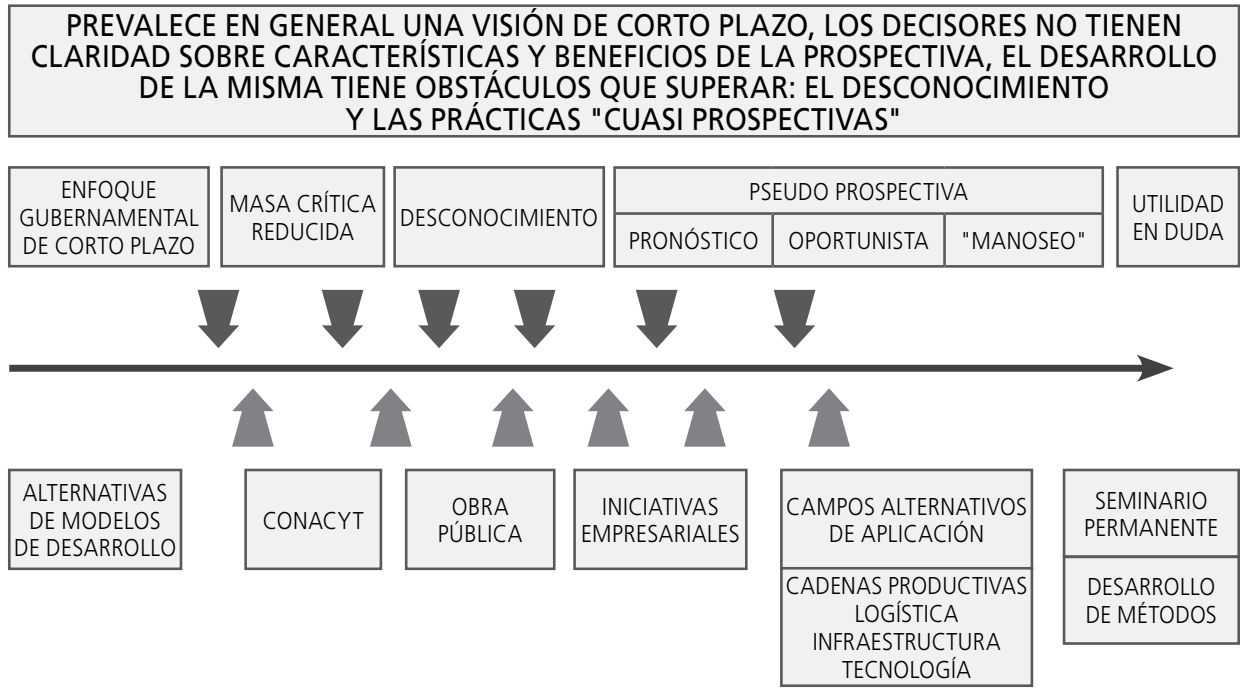

Hay interés en el largo plazo sobretodo en campos emergentes y por la necesidad de alternativas de modelos de desarrollo, se cuentan con los cimientos suficientes.

\section{Primero lo bUeno, FUERZAS IMPUlSORAS DE LA PROSPECTIVA}

Hay fuerzas que están impulsando la prospectiva en México:

- México necesita nuevos modelos de desarrollo de país

- El CONACYT apoya el desarrollo tecnológico con el requisito de un estudio prospectivo de carácter exploratorio. 
- Igualmente las licitaciones de obra pública están requiriendo estudios prospectivos.

- Se están generando visiones a largo plazo (2030) desde la iniciativa privada: IMEF 2012, Colegio de Ingenieros,

- Se mantienen los campos tradicionales: política, educación y salud; pero donde se manifiesta necesidad es en los espacios productivos y tecnológicos.

- El seminario permanente, hoy por hoy, es prácticamente el único espacio promotor de la prospectiva.

- Se están desarrollando nuevos métodos para el análisis prospectivo.

\section{AHORA LO MALO: LAS FUERZAS RESTRICTIVAS}

- El pecado original: la visión de largo plazo se ve obstaculizada por los tiempos de gobierno que son electorales.

- Tenemos pocos prospectivistas en el país.

- Entre el público en general y funcionarios públicos y privados existe desconocimiento sobre los alcances y características de la prospectiva.

- Nos estamos inundando de "pseudo prospectiva", se presenta como exploración del futuro y cabe de todo.

- Se confunden aún los pronósticos con la visión prospectiva

- Hay prácticas que se venden como análisis prospectivos que solamente son visiones personales, fundadas o infundadas.

- Hay estudios prospectivos que solo se basan en el espíritu prospectivo - discurso, sin sustento metodológico.

Estos elementos son los riesgos que corremos, hoy en día están produciendo insatisfacción y/o "vacunación" contra la prospectiva. A mí me preocupa eso, porque si estoy hablando de que todavía se desconocen los beneficios y de repente las lámparas están en eso que no es prospectiva, pues tarde o temprano se nos va a convertir en un círculo vicioso de prospectiva nociva, es lo que me preocupa, y por lo tanto la utilidad de la prospectiva se confunde. Obviamente existen más fuerzas impulsoras y más fuerzas restrictivas, para mí por ahora éstas son las que están presentes de una forma más generalizada en el desarrollo de la prospectiva. Entonces, como un resumen de esto, yo diría que prevalece la visión de corto plazo, los decisores no tienen claridad sobre características, el desarrollo de la misma tiene obstáculos como superar el desconocimiento y las prácticas pseudo o cuasi prospectivas. 
Qué bueno que ustedes se están formando en prospectiva, en México existe un estudio de posgrado en prospectiva en el Tecnológico de Monterrey, campus Monterrey, pero todavía no sé qué está pasando con sus egresados; y con el Seminario se están impulsando los diplomados, la especialización buscada, pero todavía lo diríamos algunos, no lo hay .Y como positivo hay interés en el largo plazo sobre todo en campos emergentes y por las necesidades de alternativas del modelo de desarrollo, pero sí tenemos muy buenos cimientos, que no los hemos sabido aprovechar.

El crecimiento es positivo, tenemos un resurgimiento por ahora discreto, hablando de estudios prospectivos, destacan los campos tecnológicos productivos. Sin embargo, aún existe desconocimiento a los procesos y déficits de la prospectiva, por lo que se genera confusión sobre esto. En el desarrollo, está creciendo el número de prospectivistas, existe formación a nivel maestría, aunque son pocos los que desarrollan métodos, se está aportando a la comunidad prospectiva internacional; aún se habla de mejorar la calidad de estudios prospectivos, se tiene que trabajar en la generación de un portafolio metodológico que garantice su confiabilidad.

Para estimar el estado de la práctica de la prospectiva utilizaré dos ejes:

Crecimiento de la prospectiva, que incluye la utilidad de sus estudios, la demanda de los mismos y el posicionamiento que tiene.

El otro eje es el desarrollo o ver hacia dentro que se integra por sus metodologías, la formación especializada y su ética y calidad.

En un esquema sencillo nos permite establecer 4 posibilidades o escenarios al respecto:

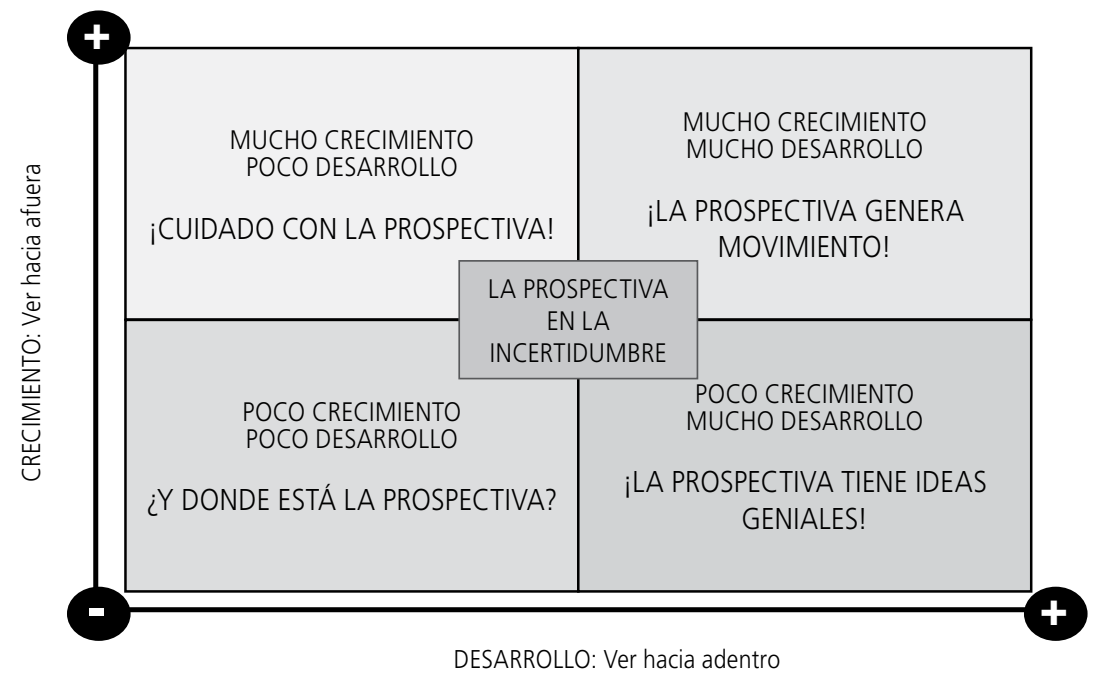


a) uno de mucho crecimiento, existe mucha demanda, pero tenemos poco desarrollo y entonces le quise llamar, ¡Cuidado con la prospectiva!, porque hay mucha demanda pero su práctica se hace con un mínimo de desarrollo, por lo que sus resultados seguramente son limitados y el movimiento que provoca puede ser negativo.

b) hay otra posibilidad, de poco crecimiento y poco desarrollo, a este me gustaría llamarlo, ¿Y dónde está la prospectiva?, porque si nadie la demanda y no se hace nada pues dónde está;

c) uno de mucho crecimiento y mucho desarrollo, nuestro propósito, la prospectiva genera movimiento, yo creo que es el propósito, se ha hablado de que la prospectiva genera cambio, se debe lograr este,

d) la prospectiva tiene ideas geniales, o sea nadie la demanda, nadie ve la utilidad pero ¡cómo formamos prospectivistas y desarrollamos métodos. Así, tenemos ideas geniales pero creo que el propósito es generar movimiento.

Hay un quinto escenario, se puede decir de transición. Estar ubicado en esa zona hoy en día, puede modificarse a cualquier escenario. Nos podemos mover a escenarios más favorables o avanzar a situaciones no deseadas.

¿Dónde veo a México? Considerando los factores que impulsan u obstaculizan su desarrollo, los dos ejes reflejan:

Crecimiento. El crecimiento es positivo. Tenemos un resurgimiento, por ahora discreto, de la demanda de estudios prospectivos. Destacan los campos tecnológicos y productivos. Sin embargo existe aún desconocimiento de los procesos y beneficios de la prospectiva, por lo que se genera confusión y dudas sobre su utilidad.

Desarrollo. Está creciendo el número de prospectivistas, existen formación a nivel maestría. Aunque son pocos los que desarrollan métodos, se está aportando a la comunidad prospectiva internacional. Aún se adolece de mejorar la calidad de los estudios prospectivos y se tiene que trabajar en la generación de un portafolio metodológico que garantice su confiablidad.

Yo ubico el caso de la situación en México casi en el centro, estamos ahí, en ese espacio de incertidumbre, tirando a estar en el paraíso. pero aún no consolidados, ¿por qué?, como está tan pegado, se nos cae el esfuerzo que habíamos hecho y se nos puede ir hacia abajo, pero también si hacemos bien las cosas podemos rebotarlo e ir hacia adelante con resultados mucho más positivos, yo no sé si mis colegas, estén de acuerdo conmigo, pero, yo lo veo ahí, estamos bien, vamos bien pero hay que trabajar mucho más, para mejorar, para ubicarnos más en el centro de la 
prospectiva que genera movimiento. Para mí es como está ahorita la prospectiva en México, mucha historia, hay mucho trabajo realizado, pero también todavía tenemos mucho que hacer para adelante.

- UTILIDAD

- DEMANDA

- POSICIONAMIENTO

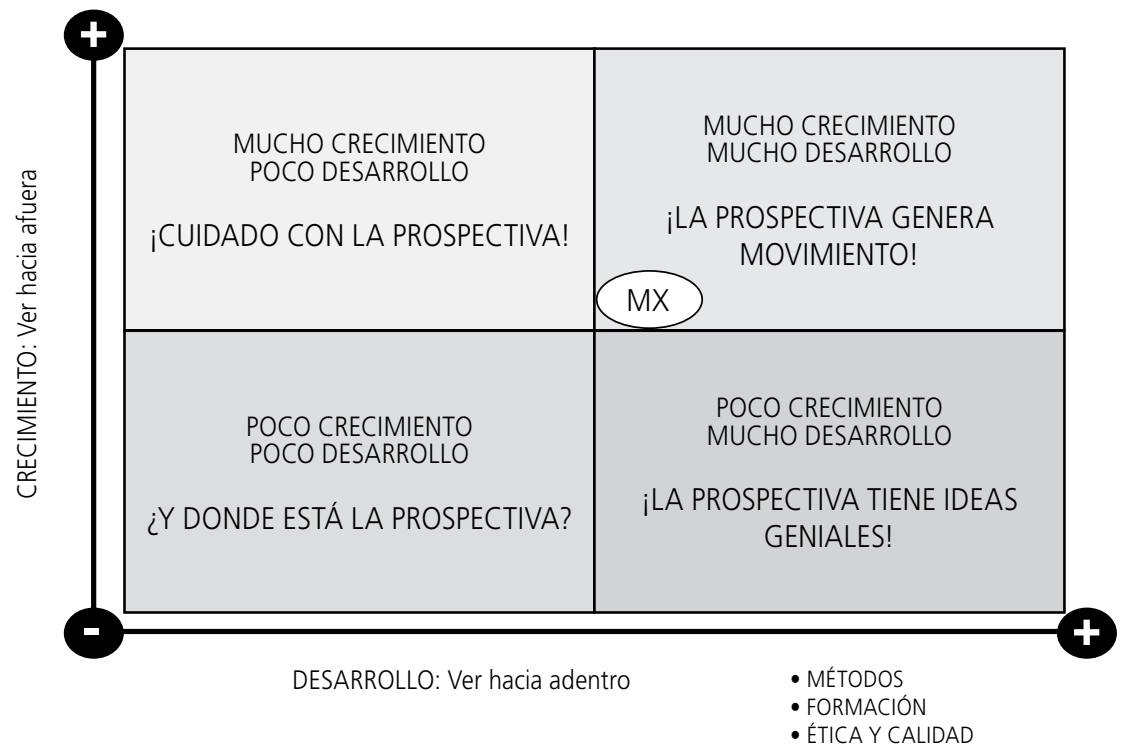

Es así como veo a la prospectiva en México, tenemos un reto importante: construir un mejor futuro para la prospectiva.

\section{LA PRÁCTICA DE LA PROSPECTIVA}

Tratando de hacer una tipología, de lo que se está haciendo en México en prospectiva hoy en día, podríamos tipificarlos de la siguiente manera: primero, igual dos ejes: la aplicación de métodos o métodos bien aplicados y significa seleccionar, o sea en tener un portafolio, seleccionar unos métodos conforme a lo que tengo que estudiar y qué tan confiables son y cómo logro integrarlos, no me voy por un solo método, sino hago un portafolio para hacer un estudio y el otro eje sería la esencia de que la prospectiva es participativa. 
Entonces va un eje desde una mínima, poca participación, hasta mucha participación y me estoy refiriendo a qué tanto en mis estudios están representados, los actores, los que viven, los productores, por ejemplo los productores de guayaba, qué tanto están viviendo, los actores son los que viven esa realidad y los expertos son aquellos que tienen los conocimientos especializados en el tema y qué también estén representados los que toman las decisiones, los que pueden y tienen la autoridad para hacer un cambio en las cosas.

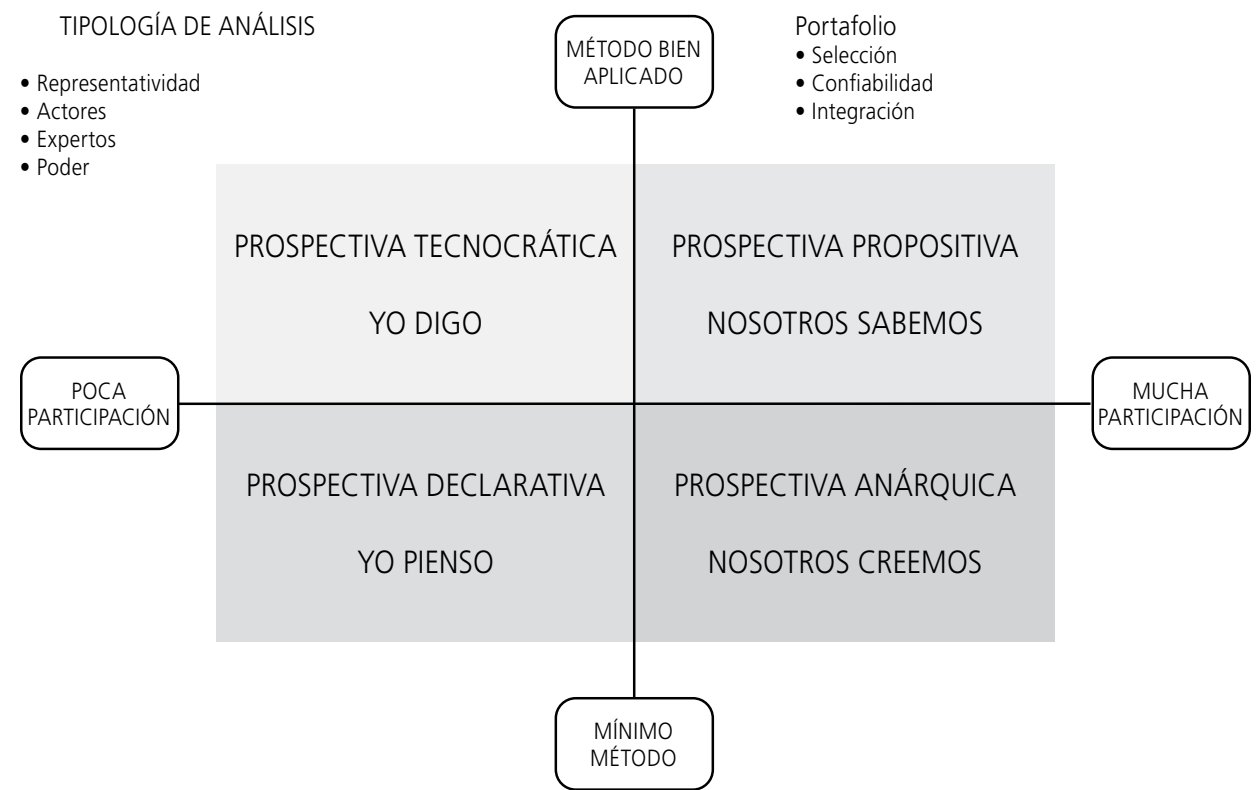

\section{Cuatro situaciones PRESENTES EN MÉXico}

1. Se puede tener análisis, pero con poca aplicación de método y tal vez de carácter unipersonal. Entonces hay estudios que cuando los veo digo, ah bueno, el autor piensa que es esto, esa es la prospectiva declarativa.

2. De repente tenemos muchos métodos aplicados, pero con poca participación y cantidad de representatividad, entonces para mí es una prospectiva tecnocrática en donde la gente que colabora dicen, yo digo.

3. Podríamos tener mucha participación, pero no método, entonces podemos presumir que hubo mucha participación, pero como no hay método, nuestros resultados podrían ser muy discrecionales. 
4. Lo que denomino prospectiva propositiva son análisis que tienen mucha participación y una buena aplicación de los métodos.

Yo no digo si los estudios son buenos o malos, digo en cómo los estamos haciendo, entonces hay estos cuatro tipos hoy en día. ¿A qué le debemos de tirar?, a un buen desarrollo metodológico con una participación correcta, adecuada, integral. En México tenemos de todo.

Ojo con esto, ustedes van a hacer los estudios prospectivos tarde o temprano ya sea como consultores, como investigadores o como usuarios y entonces sepan que se encontrarán ante las cuatro posibilidades. Les invito a situarse en el cuadrante de prospectiva propositiva.

Con esto termino lo de prospectiva en México, ese es mi punto de vista de cómo está la prospectiva en nuestro país, a pesar de lo que puse por ahí, yo creo que se llevan el mensaje de que estamos trabajando, estamos mejorando, estamos mejor que hace unos años pero todavía no llegamos a algunos niveles que tuvimos en los 70 y los 80 s.

\section{NUESTRA PRÁCTICA}

En Inteligenzza firma consultora especializada en prospectiva, aunque parezca comercial, para el desarrollo de los estudios partimos de las preguntas típicas de la prospectiva: ¿cuál es el futuro si se mantiene actuando de la misma manera? ¿qué pasa si ocurre esto?, ¿qué pasa si no ocurre?, ¿cuál es el impacto negativo o positivo de no modificar las tendencias?, ¿qué se debe intentar procurar?, ¿qué se debe impedir procurar?

Nosotros buscamos dar respuestas a esas preguntas a través del análisis prospectivo; para esto el primer elemento es el ciclo de la inteligencia, que nos define que la inteligencia es la capacidad de comprender y conocer diversas situaciones para poder actuar de manera efectiva ante ellas, pero esto requiere una búsqueda de información, hoy en día tenemos mucha información, entonces hay que seleccionarla, no toda la información es útil, entonces el ciclo es: busco información, la selecciono, la analizo y genero un conocimiento que me permita tomar decisiones, o sea dar respuestas a través de este ciclo. 

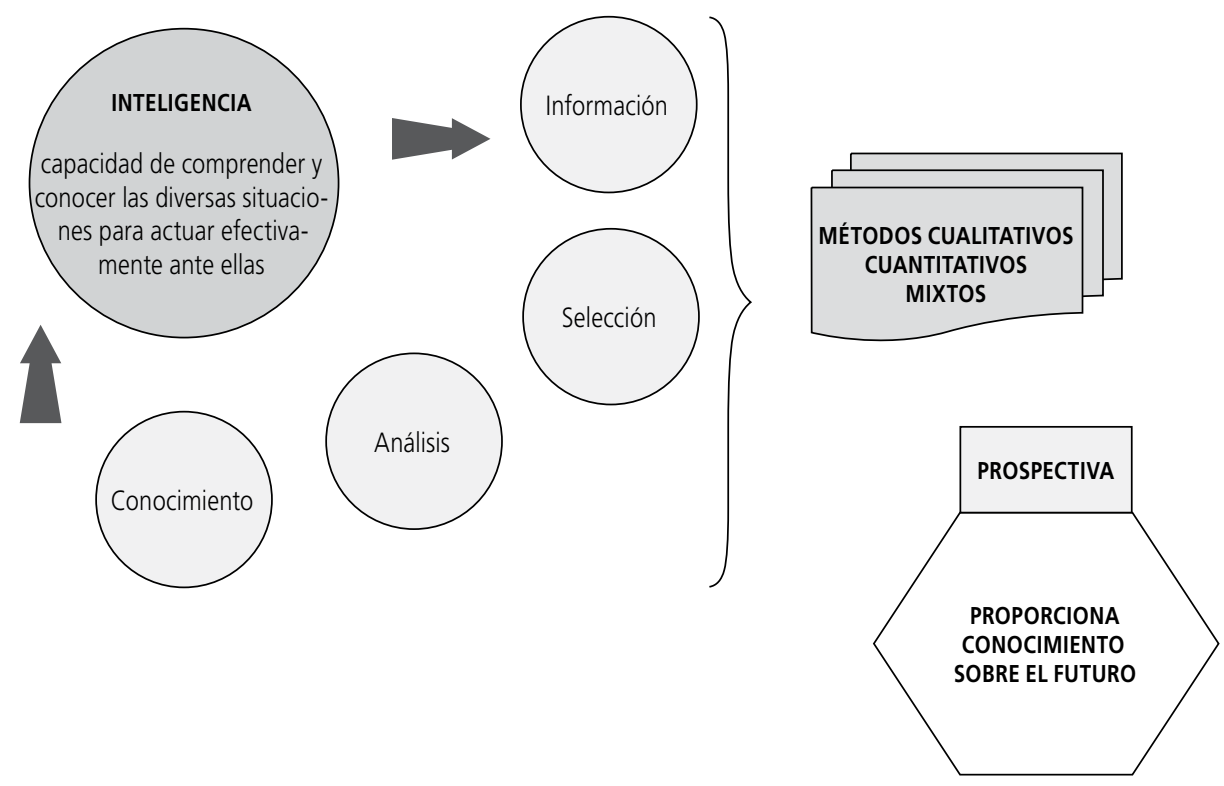

En el caso de la prospectiva nosotros aplicamos este ciclo de la inteligencia, a través de métodos cualitativos y cuantitativos, un portafolio mixto que nos permita lograr la información, seleccionarla, analizarla y generar el conocimiento: dar respuestas.

El objeto de la prospectiva es generar este conocimiento pero sobre el futuro, es un ciclo de inteligencia enfocado al futuro, para obtener información del futuro y aterrizándolo en prospectiva competitiva, tecnológica, regional, de negocios, económica, política, organizacional, sectorial.

En nuestro caso, nos hemos tratado de concentrar en el proceso de la elaboración del estudio y manejo metodológico para su aplicación en diversos campos, concretamente andamos mucho más en lo tecnológico, territorial, económico, organizacional y sectorial. 


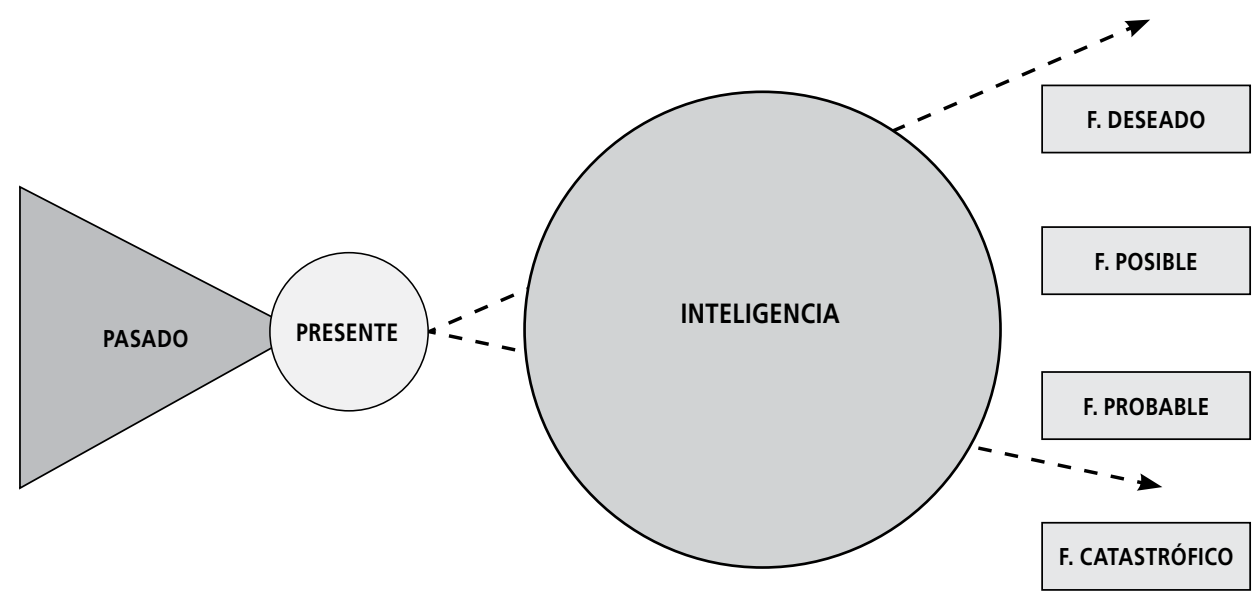

Recuerden que estamos viviendo el presente, el pasado ya es historia, decían el pasado ya pasó y no lo podemos modificar, lo que sí nos enseña el pasado es entender por qué estamos hoy en el presente, por eso es muy importante comprender el pasado, si estamos bien o estamos mal es por lo que hicimos o dejamos de hacer en el pasado y el futuro es múltiple, no hay uno, son distintas posibilidades o escenarios. Lo importante, que ustedes ya lo saben bien, es que el presente lo vivimos, el pasado ya pasó, y el futuro está por construirse.

Siempre se nos ha dicho, que el futuro pertenece a la voluntad y al movimiento, esto es importante, porque en la voluntad vamos a tener que ver mucho la cuestión de los actores, un trabajo cultural de la visión de largo plazo, de la posibilidad de generar, de cambiar, pero ahorita me voy a referir al movimiento, si el futuro pertenece al movimiento, lo que procuramos nosotros es estudiar el movimiento, entonces, el movimiento es un cambio y aquí voy a citar premisas de la física, el movimiento es un cambio de la posición de un cuerpo a lo largo del tiempo respecto al sistema de referencia.

México está hoy en 2014, 28 de julio, de determinada forma, mi pregunta es, cómo va a estar en 30 años?. Entonces, México (cuerpo) cómo se moverá a lo largo de un tiempo; tengo que estudiar ese movimiento y para esto, voy a pensar en las leyes de la física, en donde dice: todo cuerpo persevera en su estado de reposo o movimiento uniforme y rectilíneo a no ser que sea obligado a cambiar su estado por fuerzas impuestas sobre él ( $1^{a}$. Ley de Newton); o sea, puedo pensar en el futuro, aquí ya no le voy a llamar cuerpo sino mi objeto de estudio, ¿cómo se está moviendo y hacia dónde va a ir si no sucede nada extraordinario?, porque aquí esta 
ley, la primera de Newton, me dice que va a estar en su estado de reposo o movimiento rectilíneo a no ser que sea obligado a cambiar, tengo que entender el movimiento, hacia dónde puede ir.

Tenemos que entender el movimiento y hacia donde está yendo. Después, también está la tercera Ley de Newton que nos dice: a toda acción corresponde una reacción, qué bueno que ya entiendo el movimiento, pero también sé que no es estático y que pueden ocurrir cosas, acciones voluntarias o involuntarias, pero que van a tener una reacción, tengo que entender el movimiento para saber cómo va a reaccionar.

La siguiente ley aplicable (la segunda de Newton) dice, el cambio de movimiento es proporcional a la fuerza motriz impresa y ocurre según la línea recta a lo largo de la cual aquella fuerza se imprime; tengo que entender el movimiento, tengo que saber que pueden ocurrir otro tipo de situaciones y tener una reacción, efecto mariposa y todos estos, y el tamaño de la reacción va a ser proporcional al impacto a la fuerza que se está metiendo, tanto para explorar cambios en los escenarios, como cuándo quiero y tengo el control para poder modificarlo.

Y otra que no tiene que ver mucho con el desarrollo del análisis, pero el físico alemán Albert Heisenberg dice que nunca es posible conocer con exactitud cualquier objeto, la interacción del estudio introduce cambios en el objeto de estudio, este es el principio de incertidumbre, como prospectivistas, una vez que nos metemos a estudiar algo y que buscamos participación desde ese momento estamos modificando el sistema. Entonces todo está en constante movimiento.

Existe el termómetro, ustedes cuando se quieren medir la temperatura, desde el momento en que ponen el termómetro están alterando tantito, pero están metiendo un instrumento frío y ya están modificando la temperatura. Entonces esto sirve para recordar la ética que tenemos que tener en el desarrollo de los estudios prospectivos, nosotros entonces, pensamos que hay que entender el movimiento.

Aquí se han mencionado las variables, mis colegas anteriores han mencionado lo que se refiere a las variables y es vital, o sea dentro de mi objeto de estudio, recuerden que un modelo es simplemente una abstracción de la realidad para lograr comprenderla y la realidad es compleja, por lo tanto los modelos buscan simplificarla para lograr entenderla, pero aquí las variables son importantes y tenemos que entender que si bien, basados en la teoría de sistemas que ya también se mencionó, bueno tenemos que entender su movimiento y como están interrelacionadas cada una de ellas, aquí de inmediato les va a recordar una matriz de impacto cruzado, un excelente elemento para entenderlo, el problema está en si tenemos todas las variables, nos están faltando y la calidad de análisis que hagamos con la matriz, 
entonces, se trata de entender; normalmente nos hubieran dicho, entender las relaciones en el sistema, yo hablaría de su capacidad de movimiento, por eso se llaman variables motrices; entonces cómo mueven, a quién mueven y de qué tamaño lo mueven, es lo que tenemos que entender, si logramos comprender ese objeto de estudio, ese sistema que estamos estudiando, entender sus relaciones, pero en términos de la dinámica del movimiento, entonces vienen otros elementos que no están dentro de nuestra cajita, que pueden ser las tendencias, los eventos inesperados, ciertos icebergs, la inclusión de nuevos actores que van a afectar el movimiento del sistema, si yo tengo claro lo que está ocurriendo adentro podré cuantificar, calificar el impacto de los elementos externos a mi sistema, me están ayudando, ayudan al sistema, o no lo están ayudando, qué está ocurriendo, pero lo fundamental para nosotros es comprender el movimiento.

Finalmente nuestro objeto es tener esos escenarios del futuro dando respuestas a qué pasa si se hace o no se hace, si ocurre tal o cual situación, entonces en este ejemplo éstas podrían ser nuestras variables.

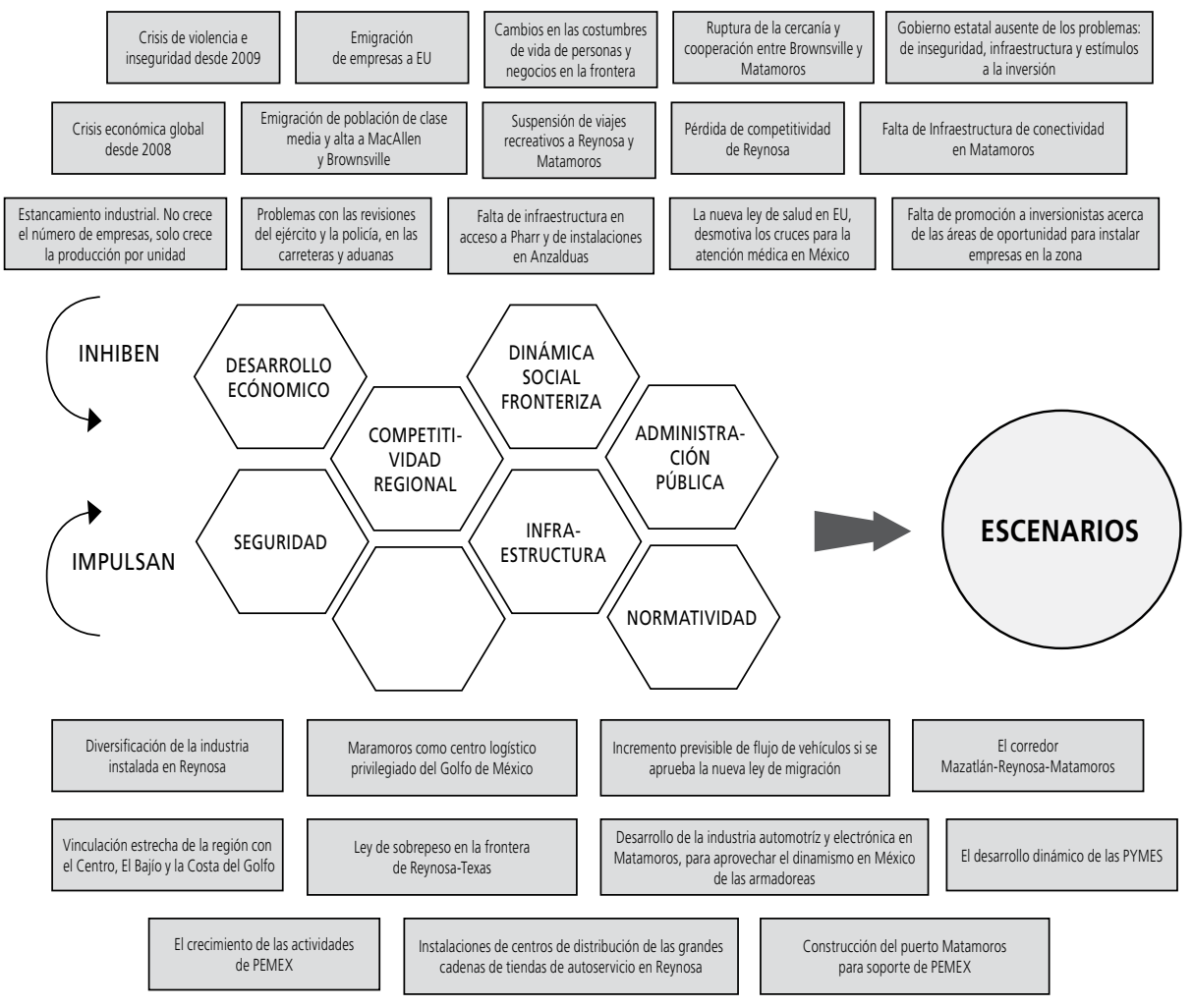


En donde dependiendo de su comportamiento, de su movimiento me va a permitir anticipar o proveer escenarios y recuerden que vamos a tener fuerzas que inhiben y fuerzas que impulsan a los escenarios al movimiento, y aquí viene una serie de eventos, de tendencias que están afectando al sistema, por lo tanto en un estudio prospectivo tenemos que entender muy bien el movimiento y saber las afectaciones que puede tener si nuestra orientación es modificar el movimiento, el conocerlo nos permite, "a mira, tengo que trabajar en esta", la variable de poder por ejemplo, porque si empiezo por la normatividad no me va a servir de nada, tengo que trabajar acá, pero ojo, porque mira aquí qué necesito, en dónde necesito trabajar, aquí hay tal tendencia o tal evento es posible que me va afectar, y entonces aquí vienen las hipótesis, vamos a suponer que unas tendencias buenas o malas se concretan, cómo me modifica eso, me va a dar unos escenarios o desaparecen todas las que inhiben al sistema y estas sí se presentan, "a bueno, estas me van a generar tal escenario" aquí puedo hacer hipótesis de escenario, pero mi modelo en movimiento es el mismo.

Entonces nosotros lo aplicamos, tanto a lo que llamamos prospectiva exploratoria por la anticipación de escenarios como a la normativa.

El proceso general de la prospectiva exploratoria, es tener claro el propósito u objeto del estudio, el enfoque, el alcance, para qué tiene que servir, debemos dar información del futuro para tomar decisiones hoy, qué tipo de decisiones se van a tomar, no qué decisiones se van a tomar, para que deben servir las decisiones, entonces en el caso de la exploratoria primero se integra al grupo de expertos, con los expertos trabajamos en la selección de las variables, entender el movimiento y normalmente para el grupo de expertos trabajamos con dos, uno que le llamamos el líder o piloto, un par de expertos tal vez reducido, y para la aplicación de tendencias, escenarios, ampliarlos a los expertos, expertos actores de poder, entonces si identificamos las variables, entendemos el movimiento y se advierte de posibles eventos, tendencias, se analizan los impactos y de aquí trabajamos las posibilidades de escenarios, normalmente nosotros podemos trabajar en 4 o 5 escenarios y una vez que tenemos los escenarios, lo que vemos es, cuál es el más probable. 


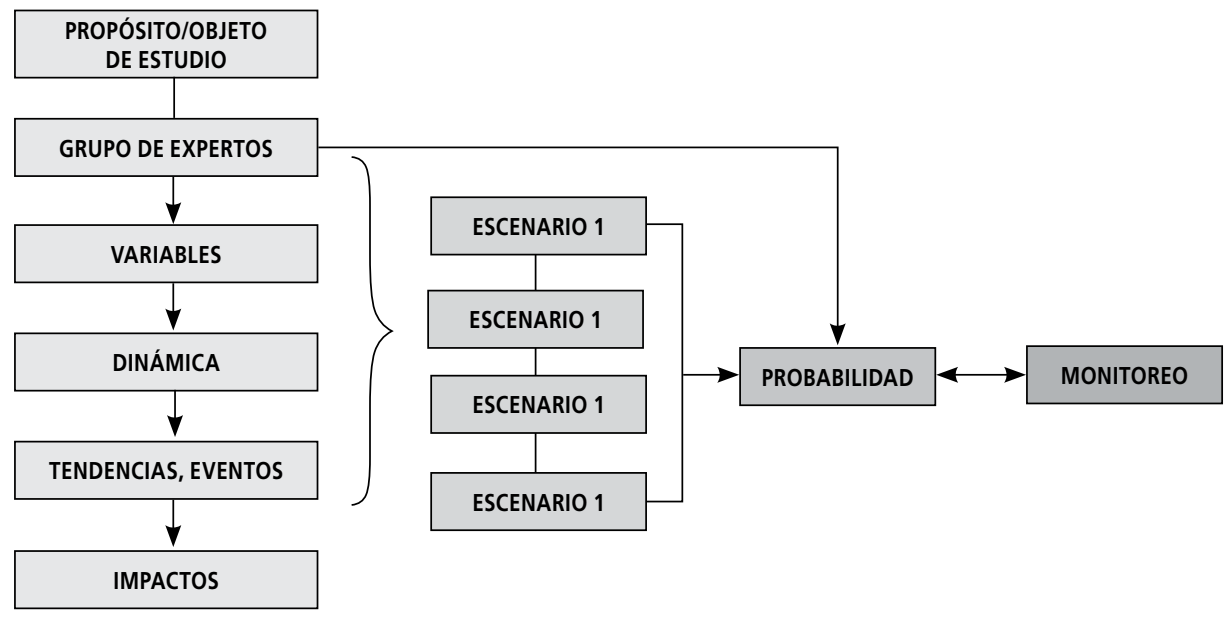

De esas cuatro posibilidades cuál es el más probable y por qué, de qué depende, bien, tengo esta prospectiva exploratoria, lo que buscamos es avanzar en algún sistema de monitoreo, un sistema vigía en donde está monitoreando a través de eventos, de indicadores, hacia qué escenarios estamos yendo, tal vez en el probable pensamos en este momento que era el escenario 4, pero como están dándose las cosas lo más probable es que sea el 2, entonces esto permite al usuario hacer planeación por escenarios, permite si el ángulo era más exploratorio, permite decir, bueno, me gusta o no me gusta, pero hacia allá vamos.

Nosotros hacemos los trabajos, pero normalmente no somos los que tomamos la decisión de qué hacer en determinado momento; en la prospectiva normativa vamos a partir del diseño de un futuro deseado, pues también se parece pero tiene ciertas diferencias, le llamamos horizonte-meta a ubicar bien el enfoque hacia la temporalidad, a dónde quiere ir la organización y entender la planeación prospectiva, igual, identificamos, seleccionamos las variables, entendemos su dinámica y a partir de las variables diseñamos un futuro deseado, de cómo se quiere ver esa institución, sector, municipio, en cuánto tiempo, en 5, 10 años. 


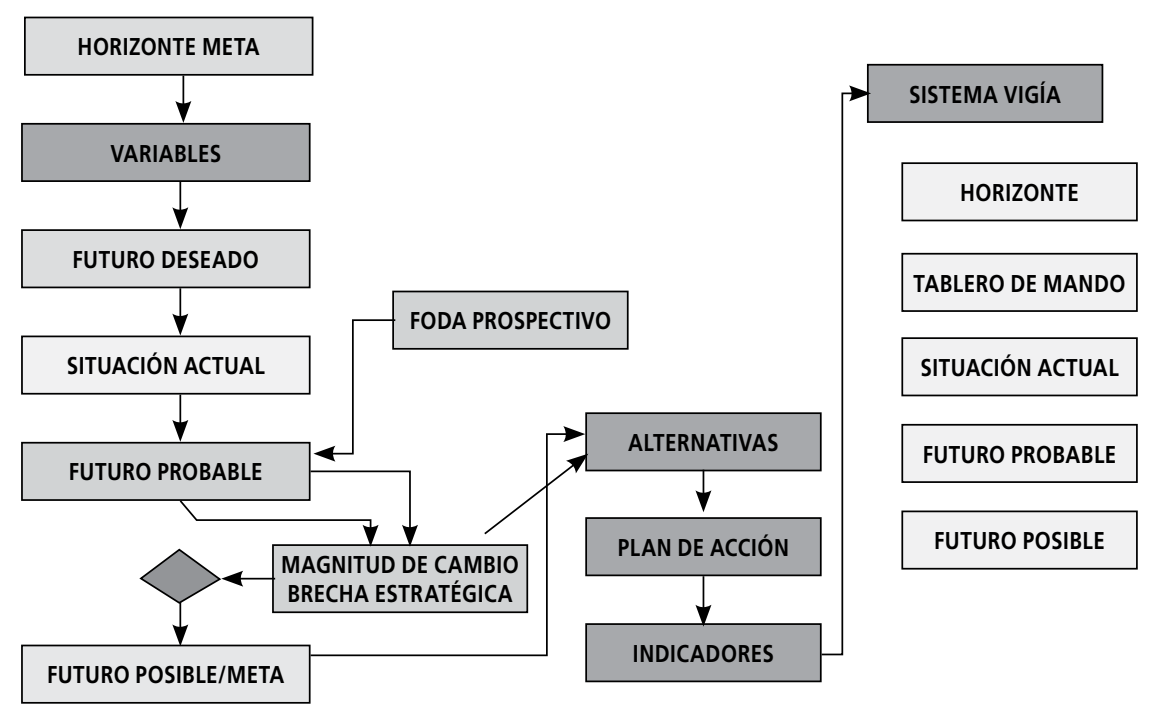

Teniendo muy claro el diseño de este futuro deseado se puede o no aplicar un FODA, un DAFO para ustedes, de carácter prospectivo, no el DAFO convencional, tradicional sino con filtros de futuro, lo que es oportunidad hoy, no necesariamente es oportunidad en el futuro o para mi futuro deseado, el que yo tenga una debilidad hoy no significa que siempre la voy a tener, el que exista una amenaza, hay que preguntarse, ¿de verdad se va a volver a presentar?, entonces, es utilizando un filtro prospectivo, aquí normalmente hacemos un diagnóstico de la situación actual pero con respecto al futuro deseado, no es que lleguemos a una organización, hagamos un diagnóstico de la situación y digamos qué se puede hacer, porque eso sería más bien reactivo; sino, yo quiero esto, esto es mi futuro deseado y en relación a lo que quiero, cómo estoy yo, entonces es una referencia y un punto de partida, el problema principal para nosotros es, bueno, esto es lo que queremos, conocemos el movimiento, conocemos la dinámica, hacia dónde van las cosas, qué es lo más probable que ocurra, entonces hacemos de hoy un diagnóstico de la situación más probable y se compara contra el futuro deseado, esto nos da una magnitud de cambio, o sea, sucede que yo quiero, no sé, manzanas rojas en 5 años, y hacia dónde voy a ir, ah pues a van a ser manzanas verdes, bueno hay diferencia, yo insisto en mis manzanas rojas, tengo que cambiar.

Pero todo depende de la magnitud de cambio, mira, yo veo un México en el 2030 de tales características y hacia dónde vamos, oye pues prácticamente vamos para allá, nos va a faltar un 5\% y tenemos 15 años para hacerlo, bueno, pues eso 
es pequeño, pero si lo llevo y voy a llegar a la tercera parte de lo que llevo, tengo que generar un cambio mucho más importante, esto a nosotros nos da una brecha estratégica en dónde el cambio es grande o chico, pero la brecha estratégica es tomar este cambio, tomar el cambio contra el tiempo disponible, yo ese cambio lo quiero en un año o lo quiero en 10, es el mismo cambio, es del mismo tamaño, pero qué tan rápido, eso es lo que me da esta brecha estratégica, que entonces normalmente aquí se va a tomar una decisión para llegar al futuro posible o meta.

Vamos a tener que valorar alternativas, viabilidad, disponibilidad de los recursos, cuándo se tiene que hacer para llevarlo a un plan de acción y normalmente trabajar con indicadores, con indicadores de gestión e indicadores de impacto, no indicadores de que hicimos la acción, porque normalmente se hace eso, hay que hacer la tarea, hoy ya hice mi tarea, oye pero no sirve para nada, pero el indicador dice que estoy bien, por eso deben ser indicadores del cambio, indicadores de impacto, indicadores de que sí estamos modificando ese futuro.

Entonces en un sistema vigía en este caso, que es algo a lo que buscamos llegar tarde o temprano recuerden que finalmente una visión sin acción solo es un sueño y acción sin visión es anárquico, entonces un sistema vigía que me esté alertando sobre el horizonte hacia donde estamos yendo, en el tablero de mando tengo los indicadores y cuando yo consulto cómo estoy hoy y hacia dónde me estoy dirigiendo, y si tengo que hacer cambios en el camino. La planeación prospectiva es interactiva, es de todos los días, a mí no me interesa generar un plan de acción, lo necesito, me interesa que cambien las cosas, si tengo que cambiar la estrategia la voy a cambiar, lo que tengo claro es a dónde quiero llegar, el cómo lo puedo modificar, ya no voy a insistir en el cómo, sino voy a insistir en el qué quiero dentro de la prospectiva.

Entonces, buscamos entender el movimiento, porque el futuro pertenece al movimiento, utilizamos métodos cualitativos, cuantitativos, entendemos el movimiento, lo aplicamos tanto para los escenarios prospectivos exploratorios como para la planeación prospectiva; para nosotros la prospectiva no es un complemento de la planeación estratégica, es una planeación estratégica, ya nos secuestraron el nombre, pero bueno ahorita le tenemos que llamar, planeación estratégica prospectiva, pero es una distinta manera de abordar las cosas, yo creo que más ambiciosa, más rica y utiliza todas las búsquedas participativas, de consenso, también que comprometen más.

Estos procesos generales los hemos aplicado en distintas áreas:

Finalmente, la fuerza de la visión del futuro es real, yo me la creo, pero tiene que ser integrado por el poder que es la conexión social y humana, hay que ser proactivos y hay que ser creativos, les doy las gracias, y estoy a sus órdenes. Les deseo el mayor éxito posible. 


\section{LA PROSPECTIVA EN LA ACADEMIA: GUILLERMINA BAENA PAZ}

n el momento actual estamos envueltos en una sociedad de complejidad, crisis y cambio, y la sociedad actual está cauterizada por la complejidad, la penetración y la incertidumbre. Ya nada tiene certeza, todo cambia en un instante, ya nada es igual, independientemente de lo que hagamos nos vamos a encontrar con el futuro.

Wallerstein decía que el mundo está entrando a un sistema histórico nuevo, del cual no podemos conocer los contornos por anticipación pero cuya estructura podemos ayudar a modelar, y es ahí donde nos insertamos los estudiosos de la prospectiva. Si seguimos en el presente pensando en el pasado, llegaremos demasiado tarde al futuro. Hemos visto cómo las falsas urgencias se multiplican y se extiende la presión de actuar de manera inmediata, y cuando algo ya es urgente, ya es demasiado tarde.

Robert Jungk, un alemán (posteriormente de nacionalidad austriaca) escritor futurista y activista social, pasó toda su vida luchando contra lo que consideró errores sociales, contra el racismo y más tarde contra la bomba atómica hasta que le tocó un día entrevistar en Japón a un hombre que se moría de leucemia a consecuencia de la bomba atómica y él le decía: "Ahora protestas contra la bomba atómica pero ya es demasiado tarde, tú siempre llegas demasiado tarde".

Ésta situación cambió la vida de Robert Jungk, quien posteriormente sería pionero en técnicas de talleres de prospectiva social en su país y que se extendieron por Europa. 


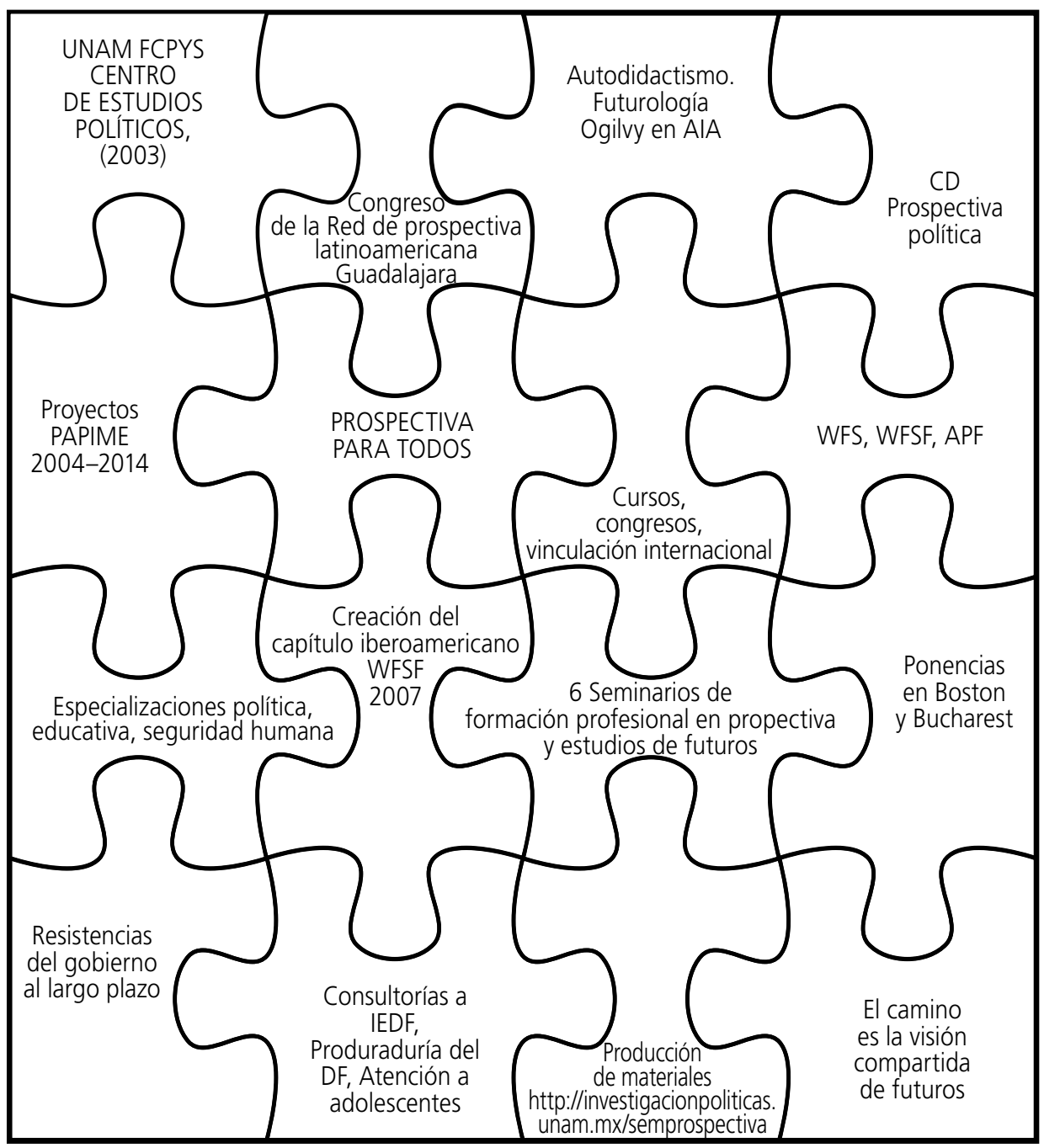

Entonces lo importante es hacernos las preguntas claves: qué está pasando, qué podría pasar y qué vamos a hacer si pasa; de ahí que la prospectiva siempre se esté moviendo al nivel de la toma de decisiones y de la estrategia que va a aterrizar en acciones.

Hemos estado trabajando durante 12 años en el Seminario Permanente de Estudios Prospectivos; las experiencias han sido maravillosas porque hemos conocido a mucha gente que está inquieta por los estudios del futuro. Pero también 
hemos conocido a quienes les da miedo el futuro, no quieren tocarlo, no quieren saber de él; sobre todo, cuando son funcionarios.

Por ello hemos llegado a concretar, finalmente, que la prospectiva es una ciencia social que nos va ayudar a definir y a entender problemas complejos de estructuras sistémicas que nos permitirá ver más allá de donde ven los ojos para reconsiderar el pasado y descubrir nuevas posibilidades futuras; es una actividad que permite la construcción de diversos futuros para tomar decisiones más acertadas ante estas situaciones y gestiona la incertidumbre Es una herramienta metodológica que nos permite sistematizar conocimientos múltiples. Es un ensayo inacabado porque el futuro no ha sucedido, pero se construyen en él nuestros sueños y esperanzas.

Como se darán cuenta, hemos recuperado las definiciones que dan muchos autores de la prospectiva porque consideramos que todas son válidas; y claro, uno de los retos más grandes que tenemos en el análisis prospectivo es nuestra capacidad para descolonizar nuestro futuro, pensarlo desde un espacio libre del porvenir y poderlo construir desde el presente de manera que pueda alcanzarse un futuro preferido, deseable.

\section{¿CUÁlES SON ENTONCES LAS CARACTERÍSTICAS DE LA PROSPECTIVA?}

Ve hacia lo lejos, hacia el futuro, pero ve desde lejos; no renuncia al pasado y ve en profundidad, en los dos sentidos; penetra hasta la mente de cada uno de nosotros, hacia nuestros futuros personales como también hacia la estructura sistémica.

También trabaja de manera holística, integradora porque ahora los problemas son transversales. Es sistémica porque organiza todo tipo de información, y es multidisciplinaria, aunque se ubica como ciencia social, integra a todas las disciplinas.

Estos elementos han constituido el desarrollo del Seminario Permanente de Estudios Prospectivos, buscando desde el principio manejar prospectiva para todos, y es una inquietud que compartimos con Fabio Grobart de Cuba, quien es uno de los más insistentes en la visión que hay que darle a toda la región, la visión prospectiva. 


\section{El Seminario Permanente de Estudios Prospectivos.}

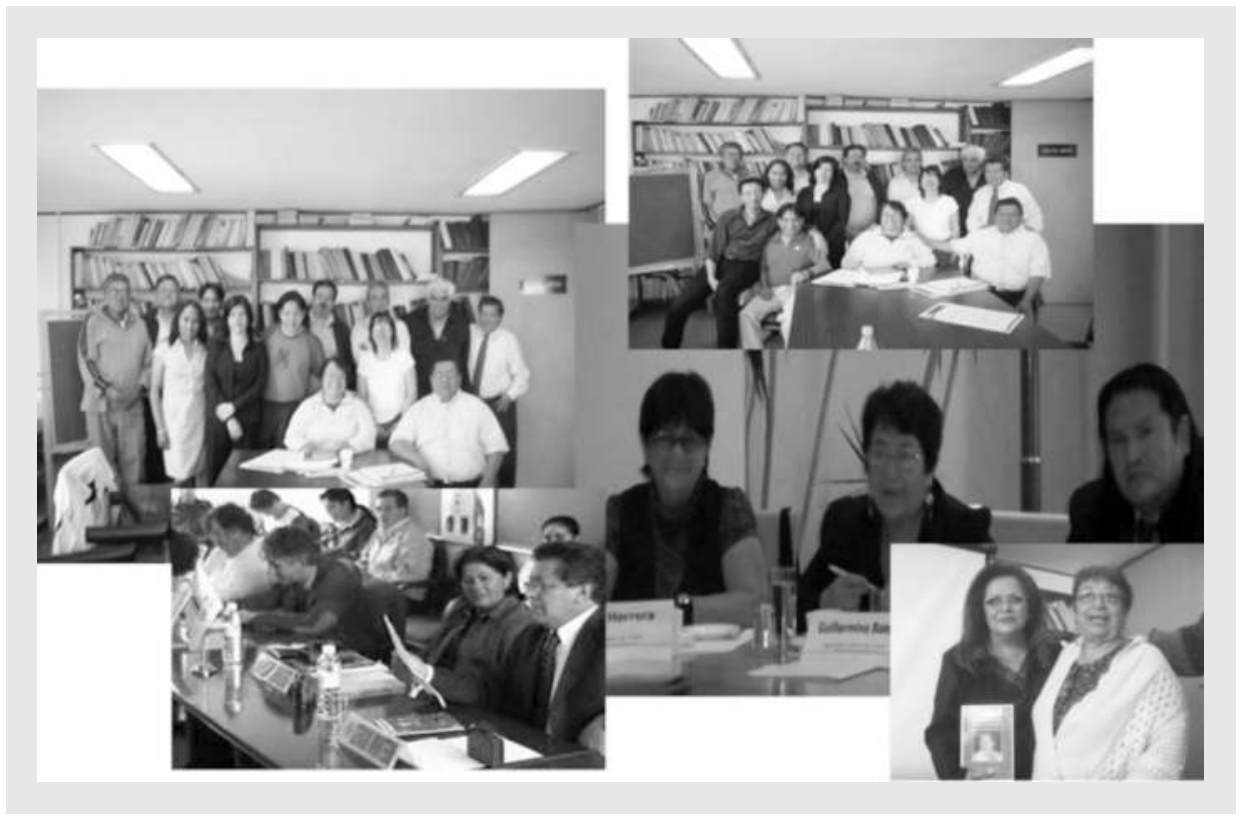

Iniciamos los trabajos en el año 2003 en la UNAM, en el Centro de Estudios Políticos de la Facultad de Ciencias Políticas y Sociales (FCPys), y nos empezamos a ligar con la prospectiva en Latinoamérica por el Congreso que se impartió en Guadalajara, Jalisco, por la Red Latinoamericana de Prospectiva en la cual el Dr. Tomás Miklos, uno de los fundadores junto a Francisco Mojica, Manuel Cervera y Axel Didriksson, tuvieron mucho impacto mientras contaban con el apoyo de la UNESCO, y paulatinamente empezó a bajar su impacto, pero la conexión que se pudo hacer y la gente que pudimos conocer en ese momento fue muy importante.

De alguna manera, entramos a la prospectiva por autodidactismo, en un primer momento habíamos oído hablar en 1992 de la Vicepresidencia de Futurología de Panamericana O'Gilvy de la Asociación Internacional de la Publicidad y nos dimos cuenta cómo la publicidad siempre iba avanzada 5, 10 o más años en relación con la situación que estábamos viviendo, por razones evidentes tenía que penetrar en los hábitos del consumidor, ya empezaba a hablar de cómo penetrar en la mente del consumidor. Y en ese sentido la empresa O'Gilvy hacía futurología, y nos preguntábamos qué es eso de futurología, ¿sacaban su bola de cristal?, igual que ahora muchos se siguen preguntando qué es eso de "futuros". 
Posteriormente empezamos a trabajar con proyectos que promueve la Universidad para el mejoramiento de la enseñanza: PAPIMES. De 2004 a la fecha llevamos ya 12 años de PAPIMES, y eso nos ha permitido hacer una serie de publicaciones a las que están ustedes invitados a revisar en línea en la página de la Facultad. (http://investigacion.politicas.unam.mx/semprospectiva)

En 2004 publicamos el libro-CD de Prospectiva Política que recopilaba nuestras ideas sobre lo que era prospectiva. En ese momento no había información, ni libros que nos orientaran para poder arrancar de manera global, integradora. Así que esto parecía un rompecabezas.

Luego, iniciamos la asistencia a cursos, congresos, talleres para tener una vinculación con las redes nacionales e internacionales. A la fecha somos ya miembros de la World Futures Studies Federation (WFSF), de la World Future Society (WFS), y de la Asociación Internacional de Futuristas (APF) que también tiene su sede en Europa, todas las Asociaciones vinculadas a las redes de prospectiva de la región.

Estos años nos han permitido trabajar algunas especializaciones, hemos trabajado la de Prospectiva Política por razones de la misma Facultad, pero también Prospectiva Educativa, Seguridad Humana, y por razones de la formación de funcionarios estamos trabajando Prospectiva Gubernamental.

Por igual, se trabajan algunas áreas de investigación sobre la Inteligencia prospectiva, el Pensamiento prospectivo y el Pensamiento anticipatorio.

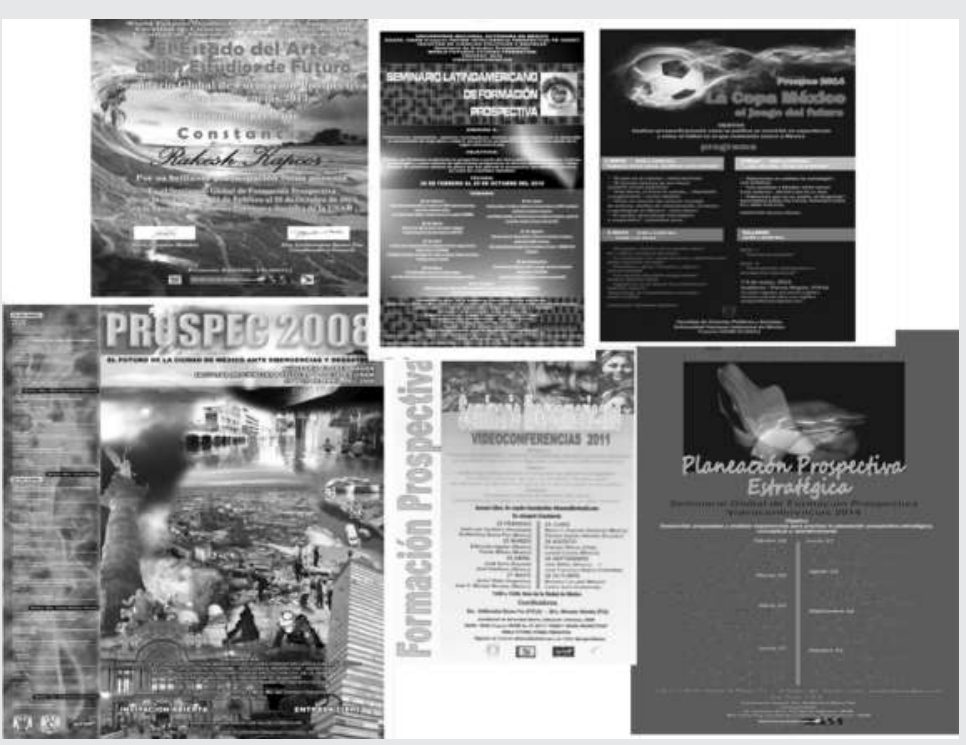


También fundamos el Capítulo Iberoamericano de la WFSF; en 2007 y hasta el momento llevamos seis Seminarios de Formación Prospectiva; empezamos con Colombia integrando la idea de Javier Medina en 2009; el siguiente seminario fue Latinoamericano, seguido de un Seminario Iberoamericano al incorporar la participación de Jordi Serra, de España; posteriormente, un Seminario Internacional con 10 países y uno global con otros diez países. Esto también ha sido un reto tecnológico para la propia Facultad de Ciencias Políticas y Sociales (FCPys), porque se realizaron transmisiones y enlaces con Israel, Nueva Delhi en la India, Hawaii y Australia entre otros países.

Actualmente, se transmite el Seminario Global de Planeación Estratégica, y por primera vez, se reunirán varios expertos en Planeación Prospectiva. Tuvimos la oportunidad de presentar ponencias en el evento de la WFS en Boston, y en Bucarest en el marco de los 40 años de la creación de la WFSF, desde el Capítulo Iberoamericano y en conjunto con la Vicepresidencia de la WFSF lo seguimos impulsando.

Claro que también hemos encontrado resistencias, resistencias contra el largo plazo por parte del gobierno, porque en este país se creía que no se necesitaba el largo plazo, los estrategas políticos solían mofarse de las exit pools norteamericanas que decían saber quién sería el presidente de los EE UU, 24 horas antes, nosotros con seis años de anticipación sabíamos quién iba ser presidente de la República Lo que sucedía es que el sistema político en el que vivíamos estaba todo bajo control del presidencialismo y por lo mismo, la visión del largo plazo no parecía necesitarse.

También hemos hecho algunos trabajos de consultoría con quienes tienen ya la preocupación por aprender y entender la prospectiva. Hemos tenido experiencias importantes con la Procuraduría General de Justicia del Distrito Federal (PGJDF), con la Dirección de Jóvenes en Conflicto con la Ley, donde también hemos aprendido y que nos han obligado a abrir una nueva tipología de escenarios, los escenarios transformadores.

Hemos trabajado en esta parte, porque estamos convencidos que el futuro se construye dos veces, primero en la mente, luego en la realidad, afortunadamente hemos tenido una apertura aquí con Alethia Montero de México y con Martha Jaramillo de Proseres Colombia, que están trabajando una nueva vertiente que se llama Psicoprospectiva, partiendo de la inquietud: "Si lo podemos pensar, lo podemos crear".

Esa práctica y aprendizaje con ellas nos ha ayudado a impulsar el pensamiento anticipatorio, con el cual entendimos que no es nada fácil para nadie la ruptura de paradigmas, enfrentarse al cambio de actitud y mentalidad ante la turbulencia y violencia de los cambios que nos acosan. Tenemos que desarrollar las tres inte- 
ligencias de la prospectiva: las inteligencias múltiples, la inteligencia emocional y la inteligencia espiritual.

La idea es entender a la mente, cómo funciona, cómo se maneja; la idea es también pensar de otra manera, iestamos haciéndonos las preguntas correctas?, debe haber preguntas a búsquedas, no a respuestas ya que de otra manera no tenemos rumbo. Esta exploración es muy linda, sobre todo cuando Nicholas Taleb empieza a manejar, cuando dice "yo quiero la inseguridad intelectual no la seguridad intelectual"; la seguridad intelectual me pone en una zona de confort y siempre estoy sobre lo mismo, lo que ya se investigó, lo que ya todo mundo ha informado, lo que ya no tiene mayor provecho. Entonces busquemos la inseguridad intelectual, busquemos aquello que nos dé respuestas diferentes y también pensar de otra manera, hacer preguntas diferentes.

Quienes hacemos planes de prospectiva tenemos que ver si nos estamos preguntando lo correcto, va una anécdota:

Dos empleados de una empresa de zapatos son enviados a África para ver si hay un mercado potencial, uno contestó: no lo hay porque todos están descalzos; el otro respondió: hay un enorme mercado potencial porque todos están descalzos.

Vamos viendo cómo se da la interpretación de la planeación prospectiva. Finalmente hemos llegado a la realización de dos guías de análisis prospectivo y proceso prospectivo: leer las débiles señales, identificar los eventos portadores de futuro; generar escenarios, plantear estrategias, elaborar objetivos y líneas estratégicas y de acción; elaborar un sistema vigía como lo llama el Doctor Manuel Cervera o un sistema de inteligencia colectiva, el cual preferimos orientar más hacia un sistema de sabiduría colectiva.

Por último, las fases del proceso prospectivo comprenden cuatro que van a determinar la planeación estratégica prospectiva: Prioridades por atender, pensar escenarios, seleccionar el escenario apuesta y planear escenarios, llegar a la estrategia, concretar las acciones y las acciones inmediatas. 


\section{MATRIZ DE PROSPECTIVA ESTRATÉGICA: TOMÁS MIKLOS Y MARGARITA ARROYO}

amos a hablar con franqueza, Colombia ha sido dentro de todo el mundo latinoamericano el país más avanzado en prospectiva, así que vamos a hablar con personas que ya saben de prospectiva.

Déjenme comentarles que yo aprendí prospectiva cuando me invitaron a dirigir la Fundación Javier Barros Sierra, con la cual ustedes tendrán la oportunidad en esta semana de platicar específicamente con Antonio Alonso Concheiro. Cada uno de nosotros de haber tomado una posición en el espacio, nos canalizamos sobre vías diferentes, sobre proyectos que ocasionalmente se conjugan, y por ello ser más casados con la gente que va a llevar las cosas a la práctica.

Haciendo una terrible síntesis, diré que la prospectiva está basada en que no vamos a hablar del destino, porque si el destino existiera entonces ya no tenemos nada qué hacer porque el destino se va a cumplir. Por ello, necesariamente la apertura del pensamiento parte de que existen futuros, futuros alternativos y dentro de ellos vale la pena tratar de conquistar y construir el futuro posible. Y esa sería la esencia de esta presentación.

Para hacer esto, quiero recordar que este asunto de la prospectiva, o en general de los estudios de futuro, es un asunto que tiene muy poco tiempo de existir, a pesar de que la humanidad ha progresado en muchísimos ámbitos, en materia de prospectiva nace durante la Segunda Guerra Mundial, tiene muy poco tiempo y con ella los estudios de futuro, la investigación de operaciones y otros estudios afines.

La prospectiva tiene como uno de sus elementos fundamentales esta combinación que no se había podido dar anteriormente entre lo cuantitativo y lo cualitativo; ese vínculo entre las ciencias duras y las ciencias blandas. 
Aquellos que nos dedicamos a la prospectiva, debemos tener esa mente abierta en donde la rebeldía hace saber que el futuro es multirreferencial, multicausal y sobre eso vamos a trabajar

Cuando platicábamos con la Dra. Guillermina Baena, sobre qué era lo más conveniente que debíamos de dar, resultó conveniente que presentáramos algo de lo cual pudiéramos ser autores metodológicamente; Margarita les platicará algunos consejos derivados de ellos y si me permiten introducir sobre una metodología que no hemos publicado aún, aparecen algunos elementos sueltos que hemos publicado en varios documentos, algunos con la Dra. Guillermina Baena.

Este es un instrumento que hemos venidos desarrollando y aplicando con un éxito aceptable. Voy a decir a qué le denomino éxito aceptable, hemos logrado concertar elementos en las visiones de largo plazo que tiñen el corto plazo, es decir, es una manifestación de la estrategia que depende de la prospectiva y no al revés como tradicionalmente se ha venido dando.

En segunda instancia, esta cuestión que nuevamente la Dra. Baena citó muy claramente, de las múltiples, fases, variables y elementos que intervienen en la prospectiva que nos permiten estudios de fenómenos complejos.

Nosotros, la humanidad no éramos capaces de estudiar los fenómenos complejos porque siempre subdividíamos los fenómenos en aquella faceta en la cual éramos más expertos, y por ello, hay una gran cantidad de estudios de proyectiva basados principalmente en la continuación de las situaciones en cada una de las ramas de conocimiento, sea ingeniería, sociología, psicología, o lo que fuera toda esta extraña combinación.

El tercer elemento por el cual me atreví a llamarlo éxito relativo, es el compromiso. De nada sirve pensar muy bien, y tenemos gente que piensa muy bien, de nada sirve tener estas consideraciones sobre el largo plazo, sobre el corto plazo, de la totalidad y las parcialidades que lo componen, si no hay compromiso de llevarlo a cabo, y es la parte donde nos hemos visto con mucha frecuencia muy frustrados: llegamos a pensar las cosas y no se llevan a cabo porque no hay el involucramiento, el consenso y el compromiso que se requiere, por eso la Dra. Baena muy atinadamente señalaba que estamos acostumbrados a corto plazo en este país y en todos nuestros países con toda franqueza, estamos acostumbrados a ser reactivos.

Aquí se trata de ser proactivo, y esto que parece fácil, no lo es, no es fácil llevarlo a cabo. Nosotros desarrollamos un instrumento metodológico que ustedes van a conocer durante esta semana muchos instrumentos metodológicos, por ello ésta es nuestra aportación a este seminario que estamos llevando a cabo con gente que conoce de prospectiva y que quieren aprender muchas metodologías. 
Nuestra metodología combina muchas metodologías y a la par combina elementos cuantitativos y cualitativos de una manera muy focalizada hacia la intencionalidad que nosotros tengamos. Esto nos permite hablar de estrategia, visualizar el presente desde el futuro y no solamente el futuro desde el presente y esto permite poder hacer planeación estratégica con visión prospectiva, y es lo que está invitando a quien lee estas líneas.

M. P. E.

MATRIZ PROSPECTIVA Y ESTRATEGIA

(Visualización gráfica orientadora)

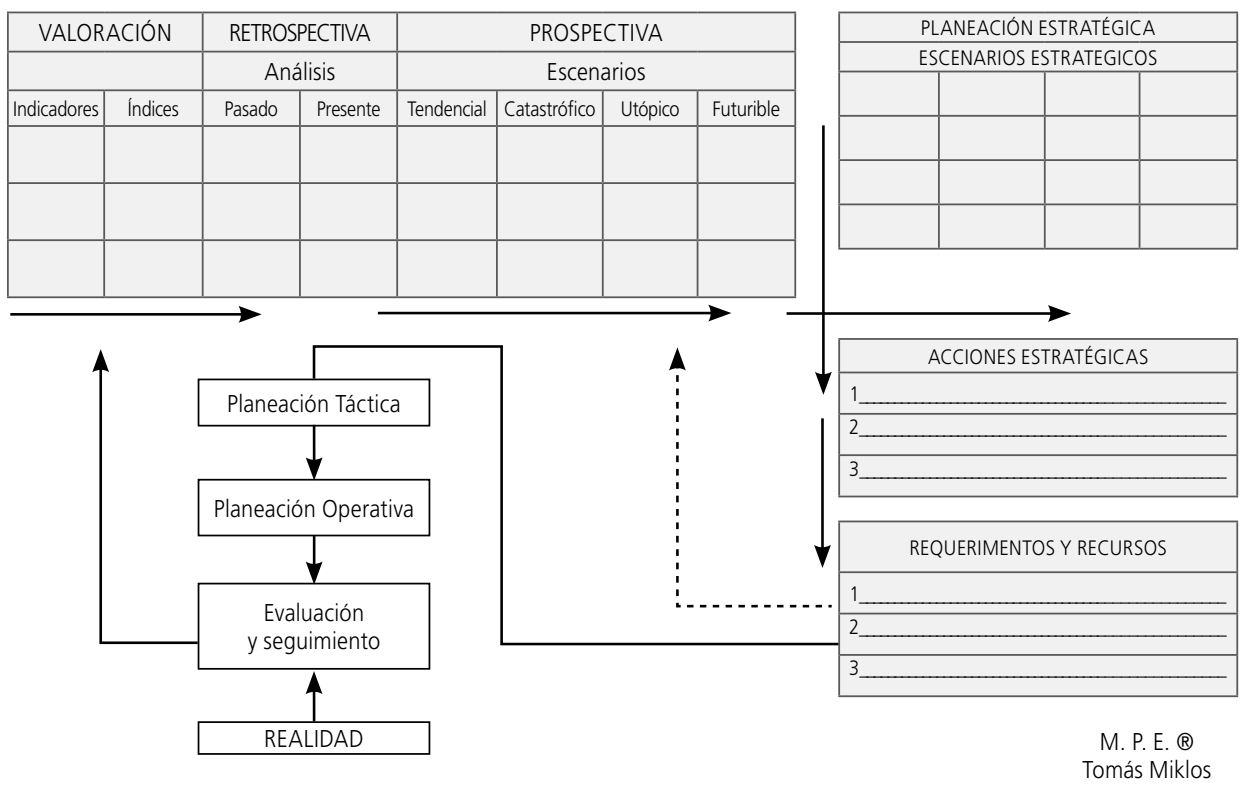

Esta lleva el nombre de Matriz Prospectiva y Estratégica a propósito, porque nos tiene que llevar a la acción de manera estratégica. Esta matriz se enmarca en el cambio de paradigmas, por ejemplo, los Estados Unidos se centran a partir de la Segunda Guerra Mundial en ganar la guerra y no en ganar batallas, puesto que las batallas son de corto plazo, mientras que la guerra es de largo plazo. Entonces en un momento dado se determina que hay batallas que conviene perder para ganar la guerra, eso es estrategia, y en este caso, estrategia militar.

Si ustedes leen la historia de la Segunda Guerra Mundial está saturada y probablemente ganamos los países aliados, gracias a este enfoque y muchas otras conside- 
raciones. Lo que tenemos en esta matriz es un eje que nos permite descomponer el fenómeno que queremos estudiar en una serie de variables denominadas indicadores e índices. Con mucha frecuencia en la literatura aparece la palabra índices o la palabra indicadores, en realidad significan lo mismo. Aquí la hemos desagregado en indicadores porque es lo que nosotros queremos comprender; y el índice es el instrumento mediante el cual podemos no solamente medir, sino apreciar y sensibilizarnos a los cambios que se han venido dando y los que pudieran darse hacia el futuro.

Algunos de esos cambios están en nuestras manos y otros se van a dar por la propia tendencia de las fuerzas sociales que hay en el entorno.

Con lo anterior, por ejemplo, cuando queremos saber de la economía de un país, muchas veces el indicador más utilizado es el Producto Interno Bruto (PIB) y el índice es el porcentaje de avance del PIB en el tiempo. Con base en ello, podemos comprender el estudio del pasado, el estudio del presente, pero lo importante es comprender el cambio entre el pasado y el presente, lo cual de una u otra manera nos puede llevar a tendencias.

Nosotros vamos a luchar en algún momento con los indicadores contra esta tendencia, la cual está implicando que el futuro es la simple continuación del pasado, esto es, materia de la proyectiva en general. Las reglas del juego siguen siendo las mismas, pero si el paradigma en el cual se sostienen las reglas del juego cambian, las reglas en el futuro serán distintas de las reglas del pasado. Entonces estudiamos el pasado y el futuro con datos que son asequibles de mayor o menor calidad que podamos obtener y muchas veces imputando la información por su mala calidad.

Lo que nos interesa es poder elaborar una visión tendencial, es decir, hacia dónde nos llevaría una situación determinada si no hacemos algo al respecto para modificarla, y que el futuro no sea la simple continuación del pasado. Esto nos permite, una vez que tenemos la tendencia, trabajarlas de manera estadística y probabilística, que es lo habitual en la práctica.

Aquí no sólo estamos manejando lo tendencial sino lo que es más probable, en algunos documentos, textos y/o publicaciones se le denomina el futurible, y al pasar de una estadística basada en la campana de Gauss, hacia una estadística más Bayesiana, nos acerca más a los futuros deseados, e incluso encontrar cuál sería el escenario catastrófico, si aquello que se ha venido dando no se mantiene y desciende. Con ello podemos pasar de lo catastrófico a lo utópico. Utópico quiere decir: qué pasaría si todo va bien, pero ya no estamos hablando simplemente de las variables, sino de la combinación que se va a trabajar como escenarios. Esta imbricación de variables es lo que determina el escenario del pasado, el escena- 
rio del presente y los escenarios de futuro, porque como muy bien lo dijo la Dra. Guillermina Baena, el futuro está en la incertidumbre; estamos estudiando la incertidumbre con elementos complementarios a las tendencias.

Con este conocimiento, esto nos permite, pasar metodológicamente al futurible; el futurible es eso que ya comentamos en líneas anteriores, el mejor de los futuros posibles, ya no digo probables, sino posibles. Y lo posible sobrepasa lo probable, con mucha frecuencia hay elementos que son posibles en un momento dado y donde nosotros tenemos también una posibilidad de influir sobre ese futuro para tener esta conquista del mejor de los futuros.

Algunos países llegan a etiquetar los escenarios con elementos muy propios del país, con la finalidad de enracimar, es decir, colocarles las raíces culturales para que esto llegue a tocar las fibras más sensibles y no solamente que sea intelectual. Así, la matriz prospectiva permite saber qué es lo más conveniente por hacer de cara al futuro.

Volviendo al ejemplo de la Segunda Guerra Mundial, hay batallas que se hicieron con la finalidad de perder para distraer al enemigo, el más claro es el desembarco en Italia para lograr el desembarco en Normandía.

Otro punto importante sobre la elaboración de los escenarios, en la prospectiva más teórica no conviene colocar fechas, en función del comportamiento del paquete de variables. Sin embargo, por razones prácticas, acostumbramos colocar algunas fechas porque esto facilita el trabajo. Por ejemplo, en el caso de México hemos venido trabajando una serie de documentos, y ejercicios prospectivos hacia el 2030, y ya conviene colocar una visualización hacia el 2050, pero cuesta trabajo.

A su vez se pueden colocar fechas intermedias de manera estratégica que nos permite irnos acercando a este futurible. Es importante aclarar que en el uso de la matriz, una vez llegado al futurible, constantemente regresamos para retroalimentar la matriz, por alguna variable e indicador que en un primer momento no se hubiera considerado.

También es importante recalcar que los escenarios no se mueven, son una fotografía. Asimismo, los escenarios son como una obra de teatro, con un primero, segundo y tercer acto; es decir, pasado, presente y futuro. Ahora bien, lo importante es saber qué necesitamos para pasar del escenario presente al futurible, y es donde viene la película, las acciones que hay que llevar a cabo para poder alcanzar esos escenarios intermedios, y alcanzar en el largo plazo el futurible.

La planeación por definición es el futuro, dentro de ella podemos ubicar a la planeación estratégica y a la planeación prospectiva, donde tenemos acciones que realizar para poder ir transitando entre un escenario y otro, aquí vienen los verbos 
de acción, cuando hablo de escenario y fotografía no hay movimiento, y cuando hablo de estrategias, ahí hay verbos de acción, lo que hay que hacer.

Ahora bien, para poder hacerlo hay una serie de requerimientos que están en este cuadro, estos requerimientos y recursos, generalmente se van sobre el dinero, y no es solamente eso, por ello no le hemos llamado recursos financieros, hay recursos temporales; recursos estratégicos, recursos políticos; política pública que se debe conquistar para poder lograr este tránsito que está planteando la estrategia.

Para ello hay dos caminos, la retroalimentación, muy de escritorio que es una retroalimentación al futurible. Si no tenemos los requerimientos que estamos necesitando no es factible confiscar el futurible, entonces es una retroalimentación permanente que nos hace girar aquí conquistando el futurible, es decir el posible de lo que se logra hacer con estos requerimientos, independientemente de la realidad, no sólo del presente, sino la realidad que en realidad sea el futurible.

Ahora bien de la planeación estratégica pasamos a la planeación táctica, de ésta, a la planeación operativa. Generalmente son tiempos diferentes, así vamos del largo plazo, hacia el mediano plazo y finalmente al corto plazo.

Esto nos permite confrontar cuando ya se llevan a cabo las cosas confrontándolo con la realidad, la cual se ha denominado evaluación de seguimiento que nos permite evaluar cómo vamos y también retroalimentar el sistema, por lo tanto no estamos hablando de un plan sino un sistema de planeación permanente que está retroalimentado por estos elementos, siendo el principal las visiones de la realidad que vamos confrontando.

Qué nos enseña la realidad: por una parte las desviaciones que tenemos con respecto a lo que se ha planeado, por lo que hay que hacer ajustes en el seguimiento del sistema de planeación. Uno de esos ajustes y que es muy importante, es la detección de elementos cuando comenzamos a hacer esta planeación que no se nos había ocurrido.

Con respecto a las mejores técnicas prospectivas, dependen de la hipótesis de trabajo del ejercicio prospectivo, es decir, cuál es la mejor técnica para alcanzar el futurible. Dentro de este gran abanico, no entramos con un prejuicio sobre la mejor técnica sino que entramos con una apertura mental y emocional sobre cuál es la mejor de las técnicas, porque lo importante no es la selección de la técnica, sino haber encontrado la mejor.

En síntesis, estamos hablando de la búsqueda del mejor de los futuros posibles, en la selección de las técnicas estaríamos hablando del mejor de los caminos, o de las estrategias posibles para alcanzarlo. 
Finalmente, algunas de las metodologías están más cargadas en los métodos cuantitativos, y otras cargadas hacia las técnicas cualitativas. La matriz que aquí presentamos encamina hacia la focalización y comprometer a los involucrados a tomar decisiones en función de lo que queremos conquistar.

El problema más recurrente es cuando se toman las buenas decisiones o lo peor, cuando no se llevaron a cabo por alguna razón, aunque imperan dos: una, la realidad, y ésta incertidumbre no nos lo permitió, a pesar de los esfuerzos que se hicieron, o a pesar de los recursos que se tenían para ello o simplemente cuando hicimos la planeación no consideramos una serie de elementos, por ejemplo, hay gente que dice que se compromete, y a pesar de que dijo comprometerse ya cuando se comprometió sabía que no lo iba a hacer, y ello es común porque en nuestro mundo hay una serie de intencionalidades que no se toman en cuenta.

Por ello la prospectiva es una ciencia y un arte, porque en realidad considera todos estos fenómenos y debe tener consideraciones de elementos más difíciles de evaluar, como pueden ser los valores, la ética, el amor, el afecto y que no aparecen en las estadísticas nacionales.

\section{RECOMENDACIONES FINALES}

Cuando trabajamos en materia de prospectiva no debemos olvidar la propia naturaleza de la prospectiva, se trabaja con el tiempo futuro, por lo tanto su objeto de estudio no es verificable, es impreciso, es interdisciplinario, transdisciplinario y multidisciplinario.

El otro rasgo tiene que ver con el arsenal instrumental que nos dan diversos caminos para aproximarnos al trabajo de construir el futuro. Partimos de los siguientes supuestos:

- La prospectiva es un saber y un arte de la conjetura.

- Su objeto de estudio es el futuro y la anticipación.

- Nos permite configurar escenarios y construir el porvenir a partir de evitar la catástrofe y construir lo deseable posible.

- Permite que las organizaciones y los individuos dejen de ser reactivos para ser proactivos.

La prospectiva debe concebirse como una herramienta de la planeación estratégica. Puede ser un muy buen ejercicio académico, pero si no se inscribe en un marco de la planeación estratégica para realizar acciones, no tiene consecuencias. 
Ningún modelo de futuro va a cambiar a realidad si no generamos acciones. Porque finalmente lo que busca la prospectiva es cambiar la realidad, tenemos que insistir en la necesidad de inscribir a la prospectiva en el marco de la planeación estratégica para generar acciones.

La prospectiva por sí misma no garantiza el cambio, tampoco predice, evita la ideologización del futuro, tal y como lo advierte Daniel Innerarity, dado que se tiende a idealizar el futuro, puesto que es un concepto abierto, donde deben combinarse elementos de racionalidad y afectividad.

También es cierto que la prospectiva debe evitar ser una tautología basada en el temor al cambio o una retórica que sólo replica presente y pasado. Es muy difícil lograr que los grupos participantes en los ejercicios prospectivos realmente se aventuren a imaginar cosas distintas a las que conocen.

De igual forma, hay que distinguir entre el pensamiento estratégico y el prospectivo, porque lo precede; es decir, primero vamos a la prospectiva, hacia dónde queremos ir y qué debemos hacer para después ir a la estrategia. Sabemos que en la planeación muchas veces se prescinde de la prospectiva y se va directamente a la planeación estratégica.

En el campo de la psicología, cuando uno tiene un paciente que es un problema, se le resuelve el problema al paciente, pero él regresa a su vida real, su familia, a su medio ambiente y no tiene el poder suficiente para que esto se modifique, sino, se modifica el todo el cual va a estar muy difícil. Es un concepto que no hemos trabajado mucho y me voy a atrever a analizar por su típica nomenclatura de ingenieros, que es la masa crítica. Para un cambio social necesito una masa crítica, puesto que, no basta un elemento que después regresa y vuelve a ser absorbido por las fuerzas que le rodean.

Por ello, el tipo de actores que necesitamos, son actores que tengan un poder de transformación.

Porque si fuera fácil, sobre todo la construcción del porvenir, ya lo hubiéramos hecho. Concéntrense en que toda lucha en este sentido vale la pena.

Hoy en día somos testigos de cambios muy rápidos, intensos, inclusive violentos, este testimonio debiera marcar, y lo está marcando, esa necesidad de una visión de gobierno, sustituido por una visión de Estado, una visión de largo plazo, sin duda esto tampoco es fácil, pero en estos momentos es más necesario que nunca. 


\section{VISIÓN CRÍTICA DE LA PROSPECTIVA: YURI SERBOLOV}

racias Doctora, me da mucho gusto que me hayan invitado a participar en este ejercicio después de que tanta gente destacada ha participado con ustedes a lo largo de esta semana y pues también yo en mis estudios he seguido mucho a la prospectiva Colombiana, me ha llamado mucho la atención que es una prospectiva, siempre basada en datos y en herramientas, es algo muy destacable, incluso yo creo que en ese sentido hasta nos han llevado delantera. Aquí en México a veces somos más conceptuales o más teóricos, entonces en ese enfoque instrumental de la prospectiva yo creo que Colombia ha sido un líder, no sé si a nivel mundial, pero por lo menos de Latinoamérica.

Yo quiero que se lleven a cabo un instrumento, que es el mapa radar del futuro, que es el que acabamos de platicar ayer, estuve ayer con una amiga que acaba de regresar de Colombia y me regalaba un llaverito colombiano, entonces yo espero que ustedes se lleven este llaverito del mapa radar del futuro, que es un instrumento que combina dos cosas, algunas variables que ya se conocían, que ya se trabajaban, pero que se les dio una reinterpretación con este nuevo instrumento.

Bueno, tenemos dos tipos de eventos, los eventos esperados y los eventos no esperados, ahí la pregunta que nos haríamos es ¿esperados por quién? y básicamente lo que diríamos es que, o son esperados por los expertos, o por una célula representativa, o son esperados por una comunidad, básicamente digamos en términos académicos o en términos institucionales, pues serían esperados a partir de un ejercicio de consulta del método Delphi, o sea de consulta de expertos, que son rondas anónimas, entonces hay toda una metodología, ahorita voy a entrar en cómo se hace. 
Luego tenemos otros dos tipos de eventos, que son los deseados y los no deseados, aquí la pregunta sería, ¿deseados por quién? y bueno, básicamente es por quienes llevan a cabo el proyecto, quienes lo lideran, cuando cruzamos ambas variables, lo esperado, sí lo deseamos: esto nos da cuatro tipos de eventos, eventos esperados y deseados, eventos esperados no deseados, eventos no esperados pero si deseados y eventos no esperados y no deseados.

Estos cuatro tipo de eventos coloquialmente se les han puesto algunos nombres, los eventos esperados y deseados son los cisnes blancos o sea es algo que nos gustaría que pasara y se espera que vaya a pasar; los científicos, los expertos, dicen esto va a pasar; luego tenemos eventos esperados, pero no deseados que les llamamos coloquialmente los cisnes enfermos o sea, es algo que los científicos dicen va a pasar pero no nos gustaría que pasara

Lluego tenemos los eventos no esperados pero si deseados que son los patos; y luego tenemos los eventos no esperados y no deseados que son los cisnes negros, que hoy en día se han vuelto tan populares.

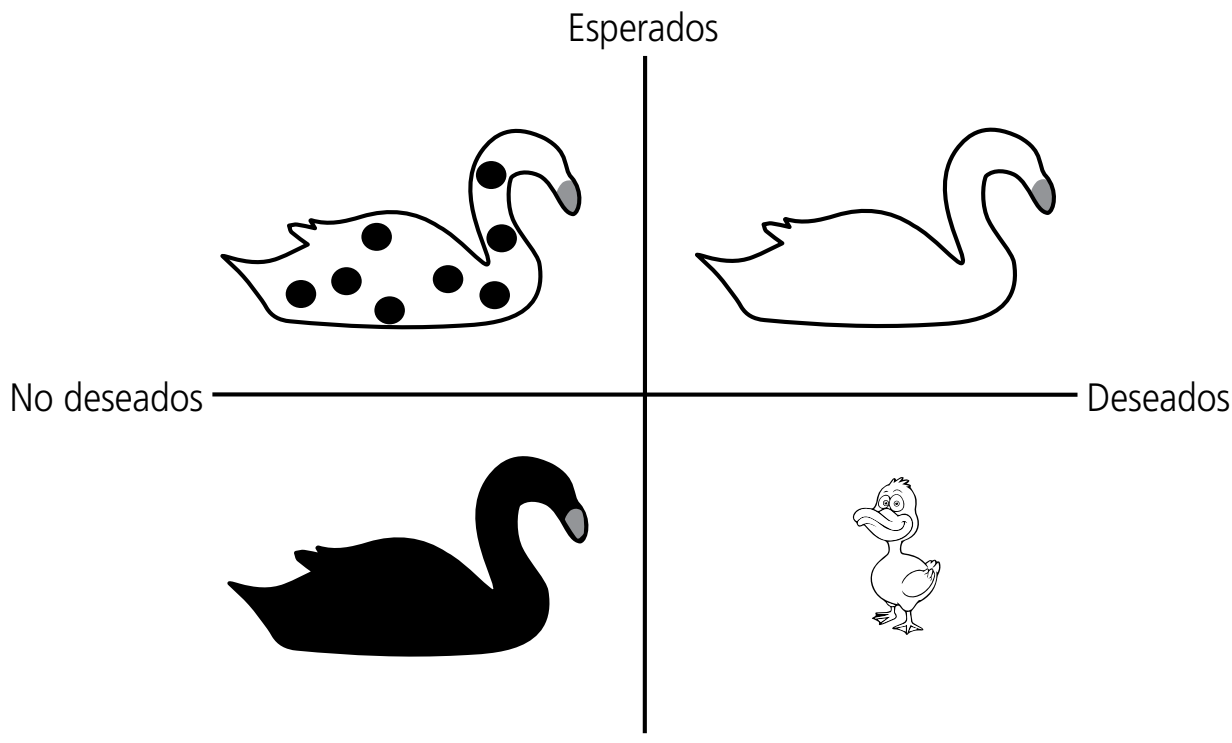

No Esperados

Si lo ponemos en un mapa cartesiano tenemos dos variables, la horizontal donde tenemos los eventos deseados y no deseados y la vertical donde tenemos los eventos esperados y no esperados, aquí podemos acomodar los cuatro tipos de 
eventos, ahí ya imagino que lo primero que nos brincaría es por qué tenemos tres cisnes y por qué tenemos solamente un pato, ¿ya con todo lo que saben ustedes de prospectiva me imagino que ya deben haber encontrado la respuesta o no?

La diferencia es que tenemos dos tipos de futuros, el futuro pasivo que son los escenarios y el futuro activo que es la prospectiva, cuál es la diferencia, en el futuro pasivo nosotros estamos viendo los toros desde la barrera, nosotros somos espectadores del futuro, simplemente decimos "creemos que esto va a pasar", en la prospectiva nosotros construimos el futuro, o sea la prospectiva, no es ver qué va a pasar sino hacer que pase, esa es la diferencia, por eso tenemos tres cisnes y tenemos solamente un pato, los tres cisnes pertenecen a los escenarios y solamente el pato pertenece a la prospectiva, o sea si nosotros hacemos una buena prospectiva convertimos ese pato en cisne.

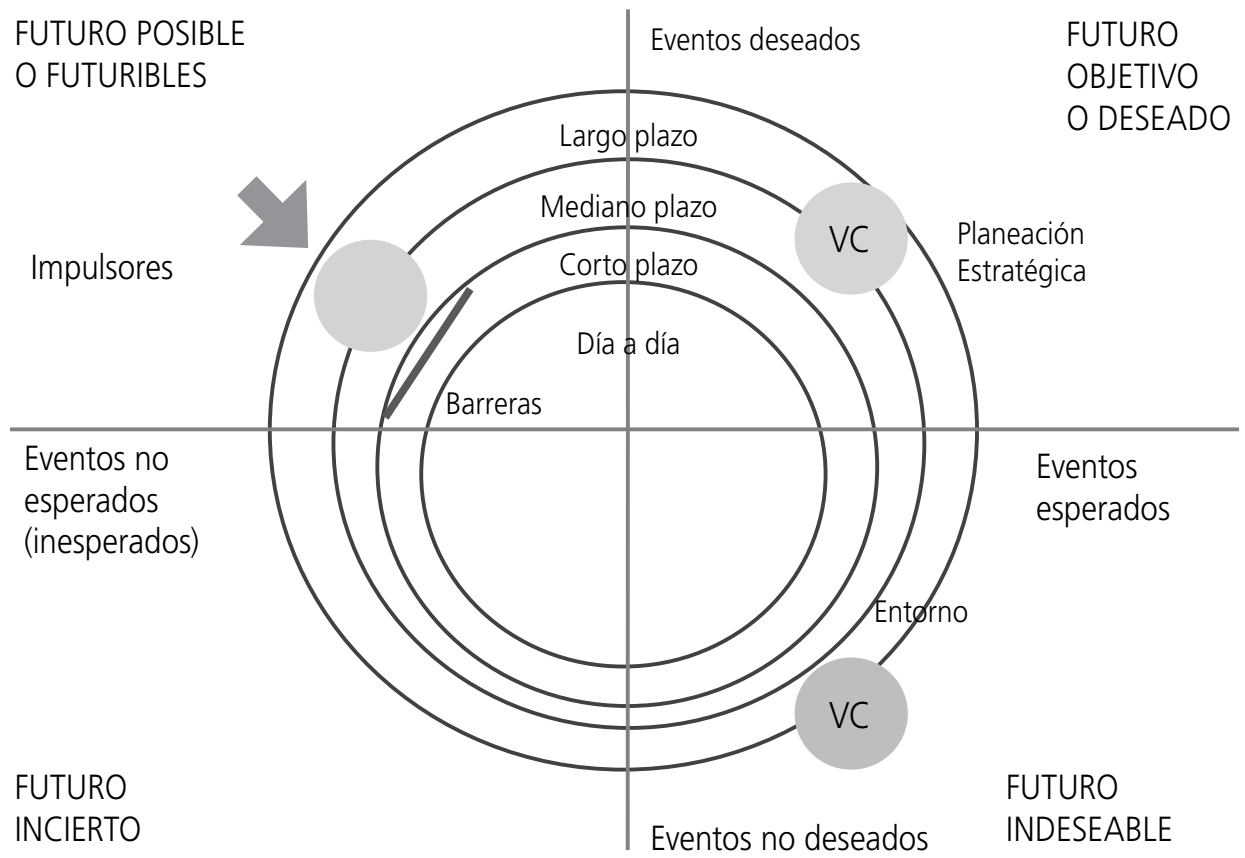

Tenemos cinco tiempos, el día a día, el corto plazo, el mediano plazo, el largo plazo y las fechas predeterminadas, si lo ponemos en el mapa radar nos da esta figura, y nosotros tenemos acá el corto plazo, el mediano plazo y el largo plazo, va otra pregunta de examen, perdón que los interrogue tan temprano, ¿dónde queda el día a día en este mapa radar? en el centro. 
Si los eventos vienen del largo plazo, pasar por el medio plazo, pasan por el corto plazo y cuando llegan al cruce ahí es el día a día, el aquí y el ahora, y la otra pregunta de examen, ¿dónde quedaron los eventos predeterminados?, que estos son los que llaman los días de, las fechas preestablecidas, por ejemplo las fechas de una elección presidencial, la conclusión de un gobierno, que son fechas que ya están en el calendario, el día de tu cumpleaños, son fechas que ya están predeterminadas, ¿dónde quedan aquí en este mapa? dentro de todos los anillos, sí porque puede haber fechas predeterminadas en el corto, en el mediano y en el largo plazo, pueden quedar acá entonces, entonces tenemos un evento que, bueno, aquí lo puse nada más que vaya viajando en esa dirección, en la dirección de la flecha, ahí puse este evento.

¿Ese puntito azul qué sería de los cuatro tipos de eventos, es un pato, es un cisne negro, es un cisne enfermo? es un cisne blanco, o sea es un evento que los expertos dicen eso va a ocurrir y es positivo, aquí tenemos los cuatro tipos de eventos en los cinco tiempos en el mapa radar, lo interesante de este instrumento es que yo digo, no sé si me puedo meter en un problema, que lo puede entender hasta un diputado no, no sé si hay aquí diputados pero, entonces no necesitas saber de prospectiva, es como que la gente no necesita saber de ingeniería para manejar un auto.

5 Tipos de Futuro

Lo que nos interesa es:

-Cuánto he avanzado en el proyecto 1. Futuro objetivo,

-Qué tiempo ha transcurrido

ideal, deseable

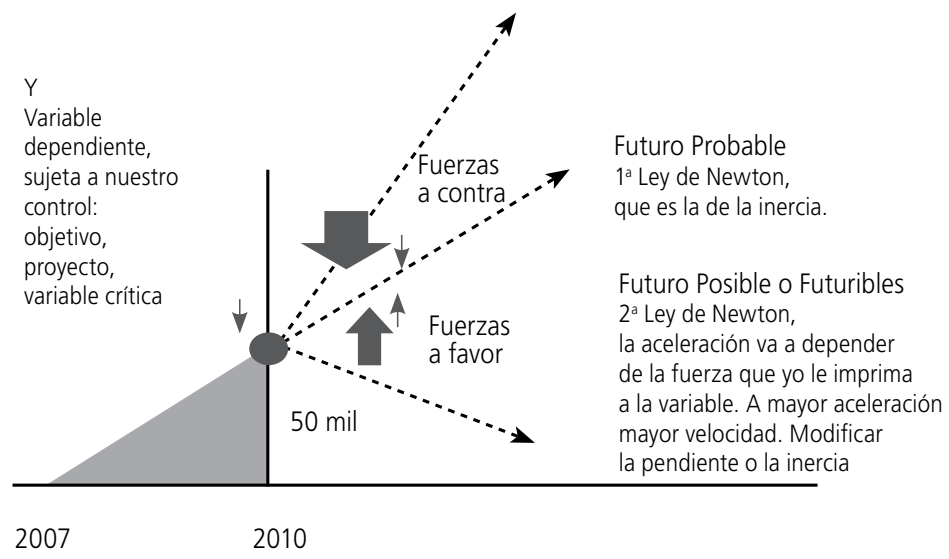

Futuro Futurible: la tensión de fuerzas

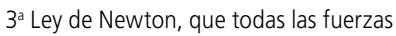

Avance en tiempo $=$ tiempo actualtiempo de origen $=2010-2007=3$ años vienen en pares y que a toda acción va a corresponder una reacción: inercia, contraparte, entorno 
Esto es un instrumento que nos permite darle a un tomador de decisión ya sea el gobierno o la iniciativa privada una inversión en el futuro, no sabe cómo se construye pero si lo va a saber manejar, ésta es la ventaja, o sea nos lleva a la prospectiva, la saca de la academia y nos la lleva a las oficinas públicas, a las oficinas de gobierno, a las empresas, a las organizaciones sociales, etc., es la ventaja de este instrumento.

Tenemos cinco futuros, el futuro probable o tendencial que yo le llamo el futuro aburrido, es que mañana va a ser igual que hoy, igual que ayer, o sea ya nos sabemos el futuro, es un futuro no divertido, luego tenemos; el segundo es el futuro deseable u objetivo que es nuestro futuro meta, que es lo que queremos alcanzar; luego tenemos el tercero, el futuro indeseable que va a ser peor que el hoy y peor que el ayer, que el futuro va a ser algo más horrible de lo que ya conocemos, es la frase esa de, "todo tiempo pasado fue mejor".

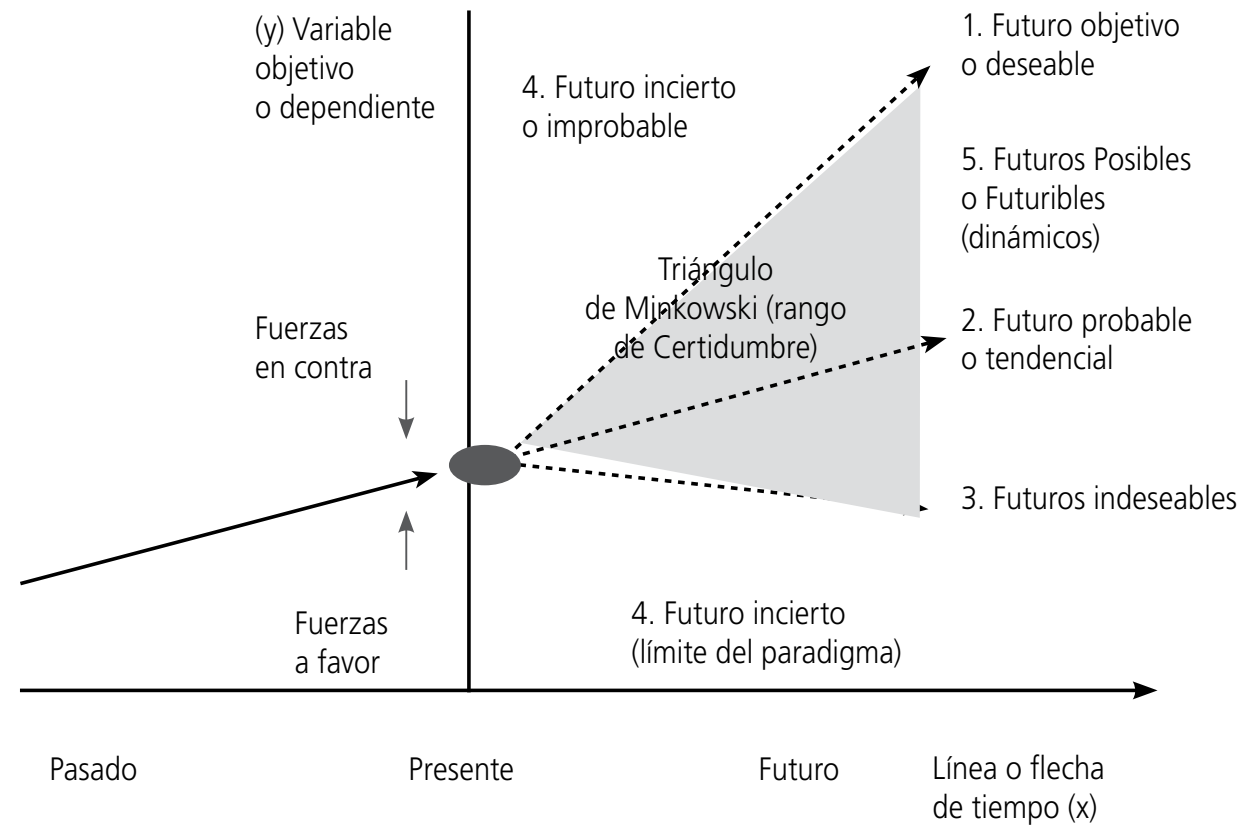

Luego tenemos el futuro incierto, que este queda afuera del triángulo de Min kowski, que no sé si han oído hablar de este triangulito, en prospectiva es muy importante, si nosotros entramos a una cueva obscura, con una linterna, la linterna hace un rayo de luz, como un triángulo, como un rayo, lo que alcanzamos a ver iluminado, ese sería el triángulo de Minkowski, se los puse acá, aunque no voy 
a entrar aquí en esta parte, lo que está en amarillo sería el triángulo, si nosotros estamos parados, vivimos en una flecha del tiempo que tiene pasado, presente y futuro, nosotros estamos parados aquí en el presente y nos estamos asomando hacia el futuro, lo que alcance a iluminar nuestro conocimiento, nuestra experiencia, es el triángulo de Minkowski, lo que queda fuera del triángulo, digamos esto estaría en negro, es lo que no alcanzamos a percibir del futuro, sería el futuro incierto, que puede ser incierto hacia muy negativo, por ejemplo, que mañana se apague el sol, los científicos nos dicen, bueno pues no se va a apagar mañana, va a durar otros 5400 millones de años, pero el sol no firmó contrato con nadie, pero si el sol se comporta de acuerdo a como lo esperamos, esperemos que se comporte dentro del triángulo de Minkowski, o puede ser que en el futuro incierto muy favorable mañana se sacara alguno de ustedes la lotería y dicen para que estudio prospectiva, mejor me dedico a vivir la vida para pasarla bien, pero esto es incierto, quedó fuera del triángulo de Minkowski.

¿La teoría de la conspiración estaría dentro del triángulo de Minkowski o fuera del triángulo de Minkowski? sería un gran debate, yo diría que está afuera, pero muchos van a decir que está adentro, se supone que adentro quedaría lo que tiene base, sustentación, etc., y tenemos acá el futuro posible o los futuribles, este es el futuro importante para la prospectiva, que depende de una balanza de fuerzas, éstos son referenciales, en realidad es el único, que son los futuros posibles o futuribles, es el único que está en plural porque es dinámico, estos son estáticos, estos los podemos definir ahorita, son puntos de referencia pero este es dinámico y se va construyendo día a día, en función del balance, del choque de fuerzas, la decisión de los actores, que era lo que platicábamos ahorita con el Doctor Sergio Montero, no está estático esto, o sea digamos que día a día estamos en la lucha del futuro, en la lucha de construir el futuro en base a nuestras ideas, nuestras concepciones, nuestras emociones, entonces todo el tiempo el futuro lo estamos moviendo o cambiando.

O sea digamos que el futuro no es algo dado como diría Isaiah Berlin en lo inevitable de la historia de que existe un determinismo, él acabó con esa lectura, o sea acaba todos los determinismos científicos, biológicos, religiosos, filosóficos, etc., digamos que los cuatro de arriba son futuros determinados y solamente el quinto es el futuro que lo estamos determinando, en los gobiernos, las empresas, los medios de comunicación, hasta en los malosos, ahora pregunta de examen ¿qué relación existe entre los cinco tiempos y los cinco tipos de futuro, se acuerdan cuáles fueron los cinco tipos? el día a día, el corto plazo, el mediano plazo, el largo plazo y las fechas predeterminadas, vimos acá los cinco tiempos y los cuatro tipos de eventos, cómo 
están distribuidos, si no tenemos el mapa nos vamos a perder en esta complejidad, el mapa nos lo simplifica y la otra pregunta de examen es ¿qué relación existe entre los cuatro tipos de eventos y los cinco tipos de futuros, o sea los cuatro tipos de eventos son los cisnes blancos, los cisnes negros, el pato, el cisne enfermo y los cinco tipos de futuro son el futuro deseable, el futuro posible, el futuro posible, el futuro incierto o futurible, qué relación hay entre estos dos?, ya con todos los expertos que tuvieron y todo lo que han estudiado, ipor qué todos tienen el corto y el mediano plazo, tiene algo que ver con lo que dicen de que nos sorprende, cuál es el que más nos sorprende de estos cuatro tipos de eventos? los cisnes negros son un concepto que nos lo puso de moda Nassim Taleb, tiene una novela precisamente dedicada a los cisnes negros financieros, porque todos los expertos decían no va a ocurrir la crisis financiera de 2009 y sin embargo ocurrió.

Ahorita lo vamos a ver un poquito más, pero ¿cuál sería la relación de los cuatro tipos de eventos y los cinco tipos de futuros?, por incertidumbre están más los dos de abajo, estos dos, este es el más incierto. Si la identidad de incertidumbre la tienen todos, ¿dónde estaría el futuro deseable? acá, dónde estaría el futuro indeseable, acá, ¿dónde estarían los futuribles, el pato?, pero no es tan fácil verlo con el mapa para ubicarlo, entonces aquí están, aquí tenemos el futuro deseado, el futuro no deseado, el futuro incierto y el futuro posible, aquí solamente faltó uno, el futuro tendencial, el aburrido ¿dónde estaría?

Ahí si va relacionada la respuesta que daba el compañero porque el tendencial puede estar en los cuatro, hay tendencias positivas, negativas, tendencias que estamos construyendo y tendencias de cosas imprevistas, se manejan tendencias en los cuatro, por eso no está ubicado en ninguno de los cuatro, por eso en los otros cuatro si están relacionados los cuatro tipos de evento con los cuatro tipos de futuro, anteriormente solamente nos interesaban los cisnes blancos que eran eventos deseados, esperados y los cisnes enfermos, pero hoy día la prospectiva puso el acento sobre los patos, la prospectiva ha desarrollo toda una ciencia de cómo construir estos patos, es cuando la prospectiva se vuelve una prospectiva sistemática, participativa, sistémica, con una metodología para crear estos, es decir, los eventos no esperados pero si deseados, o sea básicamente es: ¿qué tanta capacidad tenemos los seres humanos de crear el futuro?, y lo que planteo acá es que la prospectiva no es adivinar el futuro, ni tener una bola de cristal, sino visualizar el futuro que vamos a crear, es decir, es inventar el futuro, icrearé el futuro? si, o sea los seres humanos somos dueños de nuestro destino, no somos víctimas de nuestro destino.

Todas las cosas se construyen dos veces, primero en la mente y luego en la realidad. Primero es el diseño lógico y luego es el diseño físico, si no lo podemos 
ver, no lo vamos a poder crear. Viene un ejercicio, a ver si fui claro en todo esto, visualiza en tu mente un futuro deseado y esperado, un cisne blanco, ¿lo pueden ver?, deseado y esperado, por ejemplo un viaje tripulado a Marte, es un futuro deseado y es esperado; ahora visualicen en su mente un cisne enfermo, un evento esperado pero no deseado, las guerras, las crisis. Ahora vamos al tercer ejercicio; ahora visualiza en tu mente un evento no esperado y no deseado, es decir un cisne negro, el atentado terrorista del 11 de septiembre fue un cisne negro, podemos ver algunos más hacia el pasado, el estallido de la nave espacial Chaneque, o sea precisamente el día que habían puesto a la maestra, una maestra muy querida muy respetada y todo el país la estaba viendo en televisión, todos los niños y de repente, la nave explota en el aire, imagínense el trauma para los niños, el impacto emocional, eso paró durante varios años todo el programa de investigación de la NASA.

El accidente de Chernobyl, se fueron de vacaciones en la planta, y aprovecharon para hacer un mantenimiento y en eso estalla el reactor número uno y todavía estaba Rusia, era la Unión Soviética atrás de la cortina de hierro y entonces los científicos dijeron, "no pues nadie vio, nadie supo, no pasó nada", afortunadamente estaba un científico finlandés haciendo mediciones de radioactividad en el ambiente y detectó esa traza de radiación y le siguió la huella y vio que venía de Chernobyl, de Rusia, dio la alerta mundial y entonces le hablaron a los soviéticos en ese entonces, dijeron "oye qué pasó", "no pues nada aquí ya lo estamos controlando".

Se movilizó la comunidad internacional y gracias a eso se evitó que estallará el segundo reactor, el estallido del primer reactor dejó inhabitada toda una zona del tamaño del estado de Tlaxcala en México, más grande que el Distrito Federal, si hubiera estallado el segundo reactor, se hubiera quedado deshabitada media Europa. De ese tamaño era ese cisne negro, para darnos una idea de lo que implica, pero qué pasa con los cisnes negros. Steve Hagen dice "ante los hechos, las personas sabias parecen necios, los expertos en cambio, lo parecen después" y dice, "en todos estos casos, como en muchos otros, las personas expertas en el tema pasaron por alto o ignoraban lo que era obvio para cualquiera que viera simplemente las cosas.

Como dice Arthur Barker "a veces necesitamos un foráneo, un extranjero para que venga a ver lo que está pasando". ¿No se saben la teoría de la rana?, la teoría dice, si tu pones un perol de un agua hirviendo y hechas una rana, al tocar el agua salta, pero si tu pones 5 ranas en un perol de agua fría y le vas subiendo la temperatura poquito a poquito haces sopa de rana, cuando ustedes llegan acá a la mejor dicen, ¿cómo los mexicanos podemos vivir aquí en el DF con tanta contaminación, con tanta violencia, con tanto?, bueno, ya se está haciendo esta 
sopa de rana, el que viene de afuera nota los contrastes, pero como a nosotros nos fueron subiendo la temperatura poquito a poquito, ya nos aclimataron, lo que dice además, es que esta falta de visión se está volviendo cada vez más peligrosa, o sea estamos llegando como a un mundo de zombis que tú dices, aguas, aguas, que hay viene esto y nadie lo ve, nadie lo quiere ver, pero aquí el mensaje para ustedes es que vamos a un mundo de cisnes negros, ustedes son la generación que le va a tocar enfrentar muchos cisnes negros en un futuro, eso es lo que le digo aquí a mis alumnos, en mi generación los cisnes negros eran más escasos, hoy día tenemos cisnes negros políticos, económicos, sociales, ecológicos, etc., entonces para eso se tienen que preparar.

Entonces ¿cómo detectar algo que es indetectable?, ¿cómo ver algo que no se puede ver?, ese es el reto de los cisnes negros; entonces vamos al cuarto ejercicio, visualiza en tu mente un evento deseado pero por ti no esperado, es decir, un pato, es decir un futuro que tú vas a crear, algo que no exista actualmente, pero que tú visualizas que puede existir.

Con todo lo que has aprendido, con todo lo que te han dicho, ¿qué prospectiva podrías crear en tu mente?, algo que no existe hoy día, pero que incluso los expertos no lo esperan, pero tú dices, yo si lo puedo ver, y si veo como lo puedo crear, pero no esperado por los expertos o por la comunidad, es decir un pato no, o sea algo que los expertos no lo tienen contemplado en su agenda, pero es algo que tú si puedes ver y que tú dices, yo si lo puedo crear y voy a sorprender al mundo con mi creación, lo puedes ver, puedes ver algo que no exista hoy día, que tú digas, esto sí podría existir si se hace x, y, z.

La comunidad es algo que no espera, pero yo creo que lo voy a hacer, por ejemplo, encontrar la paz en Medio Oriente, yo voy a encontrar la manera de que se vuelvan a besar los Judíos con los Palestinos, ah eso sería la siguiente cuestión como lo creo, ¿si lo pudiste hacer? no lo tienen que decir eh, a lo mejor es top secret y es algo confidencial y es algo que tienen ahí guardado, tienes derecho a reservarlo.

La pregunta es ¿lo pudiste ver o no lo pudiste ver?, si lo pudiste ver ya acabaste tu primera prospectiva, o sea ya no estás estudiando prospectiva, ahora eres un prospectivista, o sea, tú creas futuros, ahora falta ver que lo pongas en papel y que lo lleves a la práctica porque la prospectiva se prueba después de que pasan los hechos. Es eso, aquí se crea y aquí está el resultado, lo puedes poner sobre la mesa, lo puedes enseñar al mundo, esa es la prospectiva.

Cuando tú creaste un futuro, no sé si ya han creado algún futuro, pero eso es muy bonito, por ejemplo, cuando un candidato que va a perder y tú haces que gane, porque hacer ganar al que va a ganar no tiene chiste, es hacer ganar al que 
va a perder, pero ya estás combinando ahí la prospectiva con la estrategia, primero tienes que crear un futuro, y luego qué, tengo qué hacer: la estrategia y luego la operación porque no hay nada peor que una estrategia que se queda sobre el escritorio, que no se implementa, o que tú dices, yo vi ese futuro pero nunca hice nada para construirlo, es, yo lo vi y luego lo construyo.

MATRIZ DEL MAPA RADAR DEL FUTURO

\begin{tabular}{|c|c|c|c|c|c|c|}
\hline & & Día a Día & $\begin{array}{c}\text { Fechas } \\
\text { Prestablecidas }\end{array}$ & $\begin{array}{l}\text { Corto } \\
\text { Plazo }\end{array}$ & $\begin{array}{l}\text { Mediano } \\
\text { Plazo }\end{array}$ & $\begin{array}{l}\text { Largo } \\
\text { plazo }\end{array}$ \\
\hline $\begin{array}{l}\text { Eventos } \\
\text { esperados y } \\
\text { deseados }\end{array}$ & $\begin{array}{c}11 \\
\text { FUTURO } \\
\text { DESEABLE }\end{array}$ & & & & & \\
\hline $\begin{array}{l}\text { Eventos esperados } \\
\text { no deseados }\end{array}$ & $\begin{array}{c}10 \\
\text { FUTURO } \\
\text { INDESEABLE }\end{array}$ & & & & & \\
\hline $\begin{array}{l}\text { Eventos no } \\
\text { esperados } \\
\text { deseados }\end{array}$ & $\begin{array}{c}01 \\
\text { FUTURIBLES }\end{array}$ & & & & & \\
\hline $\begin{array}{c}\text { Eventos no } \\
\text { esperados y no } \\
\text { deseados }\end{array}$ & $\begin{array}{c}00 \\
\text { FUTURO } \\
\text { INCIERTO }\end{array}$ & & & & & \\
\hline
\end{tabular}

Entonces ¿si viste el futuro en tu mente? ¿Si tienes un futuro ahí?, puede ser muy chiquito, a lo mejor puede ser para tu familia, o para tu comunidad, o para tu empresa, o para tu gobierno, o puede ser nada más a nivel personal, esos futuros a lo mejor la gente los empieza a construir cuando toma su primera decisión en la vida, ¿Cuál sería La primera decisión importante que toma una persona así en su vida? todos han vivido me imagino, o sea tu naces y toman todas las decisiones por ti no, hasta que llega un momento en que dicen ¿y tú qué vas a estudiar?, en algunos no nos dejan elegir esa, pero si te dejaron entonces tu dijiste, estudiaré ingeniería o estudiaré medicina o, ahí están tomando una decisión y la están tomando a una edad totalmente irresponsable, que uno no sabe ni en la que se está metiendo no, luego viene la otra decisión más irresponsable todavía, "casarse"(responden), yo no dije nada, ¿la tomas con responsabilidad o con irresponsabilidad, bueno algunos con las dos no, para eso tienes que estar como enamorado, así como nublado para animarte a echar el brinco no, dices tú, si hubiera estado en mis cuatro cabales, en mi juicio, quien sabe, si me aviento a esa, entonces aquí la pregunta es ipudiste 
crear tu futuro? si no lo puedes ver, no lo vas a poder crear, si no lo puedes ver en tu mente, jamás va a poder existir en la realidad, porque decía, todas las cosas se quedan dos veces, primero en la mente y luego en la realidad, si lo ponemos el mapa radar al nivel de una persona, la vida de una persona por ejemplo tenemos algunos eventos esperados no deseados como la enfermedad, la vejez, la muerte, las pérdidas, qué faltaría, serían las cuatro, serían cuatro cosas esperadas en la vida, pero no las deseamos, a cierta edad, la muerte ya pasa de acá no, se vuelve deseado, pero no creo nadie quiera, bueno, de hecho luego hay suicidios.

La vejez yo creo que nadie la desea o la enfermedad o la pérdida, son generalmente eventos esperados no deseados; algunos cisnes blancos, hacer un viaje, tener un título, comprar una casa, un pato podría ser sacarme la lotería, pero si no compro boletos o el billete entonces ya sería un cisne negro no, sacarse la lotería sin haber comprado, es decir, me lo encontré tirado en la calle, entonces ya dependería de una probabilidad, esto para ver cómo podemos aplicar el mapa radar a nuestra vida personal.

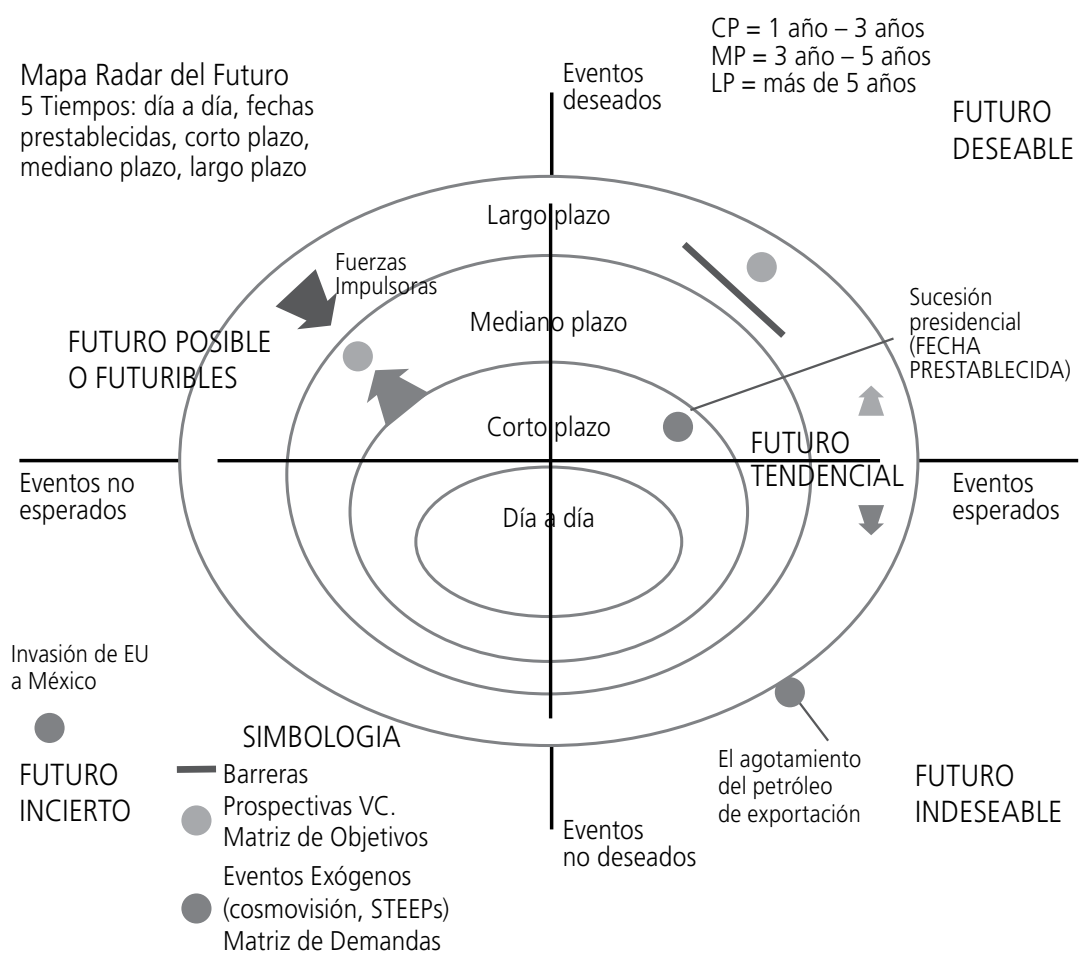


Algunos otros ejemplos serían un mejor trabajo buscado, tener un hijo deseado, porque tener un hijo no deseado qué sería, tener un hijo fuera del matrimonio no deseado ¿sería un cisne negro no?, un domingo 7, enamorarte estando soltero ¿qué sería?, es un cisne blanco, pero enamorarte estando casado ya ahí ese es un problema, o ser encarcelado, entonces esto es para ver cómo lo podemos aplicar, nosotros le podemos poner barreras a ciertos eventos, estas navecitas que vienen para que estas no avancen, o sea no estamos mancos, podemos actuar en el futuro o podemos poner fuerzas impulsoras para que cierto evento ocurra u ocurra más rápido, antes de tiempo, ahora, ¿quiénes crean estos eventos?, cada evento nosotros decimos es como una navecita, unos salen de nuestra planeación estratégica con prospectiva, nosotros los creamos, otros los que hagan nuestros enemigos: la contraparte, nuestra competencia, otras naves las crean los terceros relacionados que vienen siendo los vecinos, las instituciones no gubernamentales, medios de comunicación, y otros vienen de los STEEPS, de los factores sociales, tecnológicos, económicos, políticos, o sea del entorno.

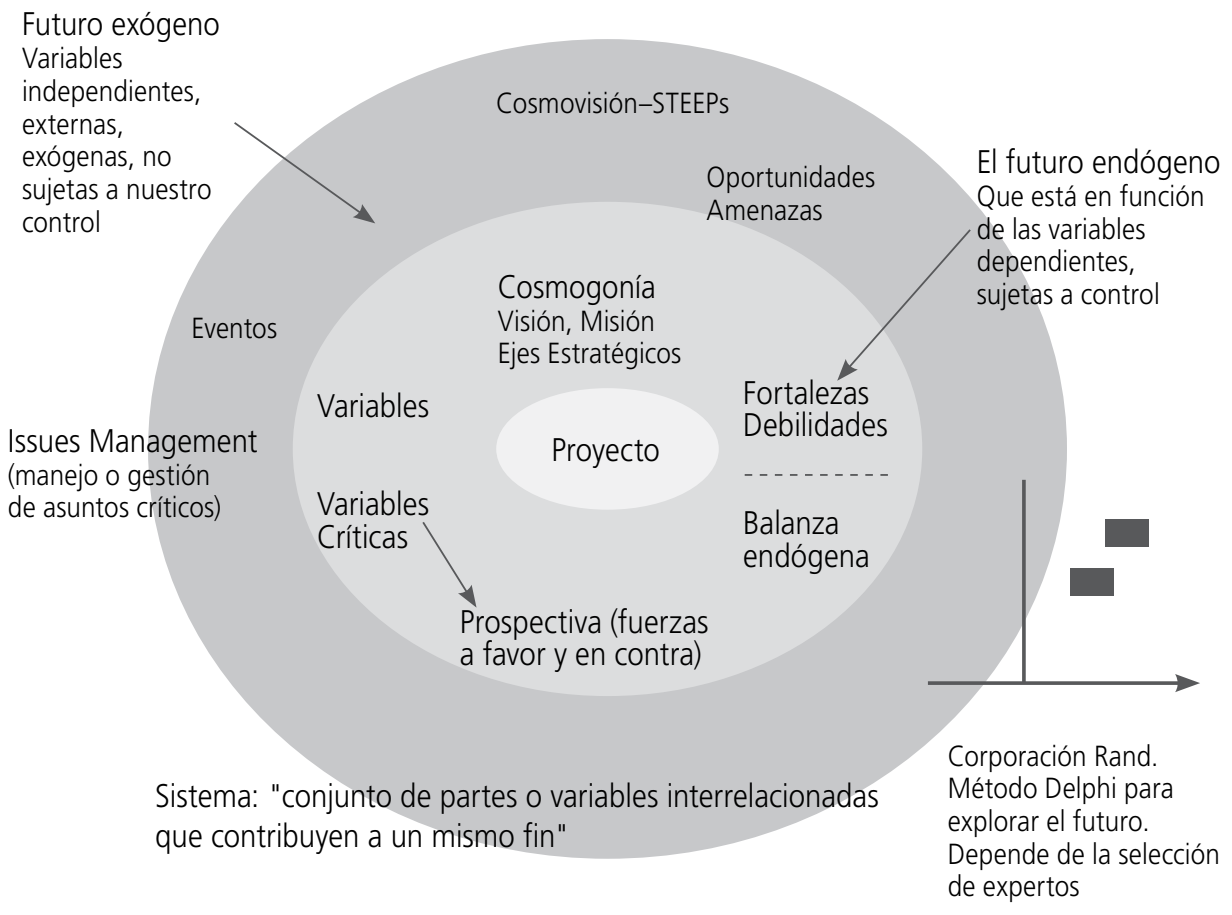


Por ejemplo, de la naturaleza, como decías un terremoto, o sea iquienes crean esas naves, esos eventos?, entonces podríamos ver las naves nuestras, las naves enemigas, las naves del entorno, ¿de dónde vienen esas naves, quién las está creando?, que normalmente es un actor, tenemos los dos tipos de futuros, el mapa prospectivo, nosotros creamos esos futuros a partir de análisis de variables críticas y las metemos al mapa radar del futuro, y otras, los cisnes, los tres cisnes los tenemos que explorar a partir por ejemplo del método Delphi, de consulta de expertos, son los expertos los que nos tienen que decir o las células representativas o la comunidad, que nos dicen aguas, ahí vienen estos cisnes, entonces podemos publicar esos cisnes en el mapa radar, como vienen, que eso es lo que hacía por ejemplo con nuestros alumnos, o sea les dividimos, tú vas a encontrar los cisnes ecológicos o los cisnes políticos o los cisnes sociales, entonces los politólogos tienen que encontrar esos cisnes.

Esos eventos esperados por la comunidad para que nosotros nos ubiquemos en el mapa, ¿ya se saturaron?, o todavía el vaso no se ha llenado, si todavía le cabe algo más, aparte del mapa radar del futuro tenemos el mapa radar del pasado, el mapa radar del pasado son los eventos que venían del futuro pasaron por el aquí y el ahora y se van al pasado, por ejemplo aquí tenemos algunos eventos del pasado, por ejemplo las torres gemelas que ya hablamos de ellas, Chernobyl, la gran depresión del 29, el hundimiento del Titanic, son eventos que pasaron y se fueron, acá tenemos, por ejemplo, la crisis inmobiliaria de Estados Unidos que es un futuro no deseado, empieza el calentamiento de los océanos, entonces nosotros podemos ver estos eventos, algunos positivos como el proyecto del genoma humano del 90, la popularización de internet en 95, la clonación de la oveja Dolly, o sea algunos eventos buenos, el primer afroamericano en la presidencia de Estados Unidos.

Podemos ubicar ahí algunos eventos que ya están en el pasado y tenemos en el mapa radar del futuro a algunos eventos; este (el ejemplo del mapa en el pizarrón) se hizo en 2010, entonces algunas de estas naves ya pasaron por aquí, por ejemplo las elecciones presidenciales de fin de sexenio del presidente Calderón en México, este ya pasó, esta navecita llegó hasta acá y ya llegó al pasado, entonces esto se ha estado moviendo, cuando juntamos los dos, el mapa radar del pasado y el mapa radar del futuro, tenemos lo que se llama el vehículo del tiempo, creo que estuvieron en la torre de ingeniería, no sé si bajaron o se dieron cuenta que en el sótano, abajo de todo ese edificio hay un túnel del viento, este túnel de viento lo ponen los científicos o los ingenieros, echan algunos objetos, y le ponen una turbina, y lo que ven es cómo se comportan ante el viento, un avión o un coche para ver la parte aerodinámica o cualquier material y lo que han visto es 
que cuando ese evento pasa por el centro del Venturi y se acelera siempre, eso es el efecto Venturi, igual aquí estamos haciendo una analogía con el Venturi del tiempo, eso se los voy a poner acá delante, acá tenemos el futuro, aquí tenemos el presente en el centro del Venturi y acá tenemos el pasado.

\section{VENTURI DE LA HISTORIA DEL UNIVERSO del planeta Tierra, de la Naturaleza y del Ser Humano}

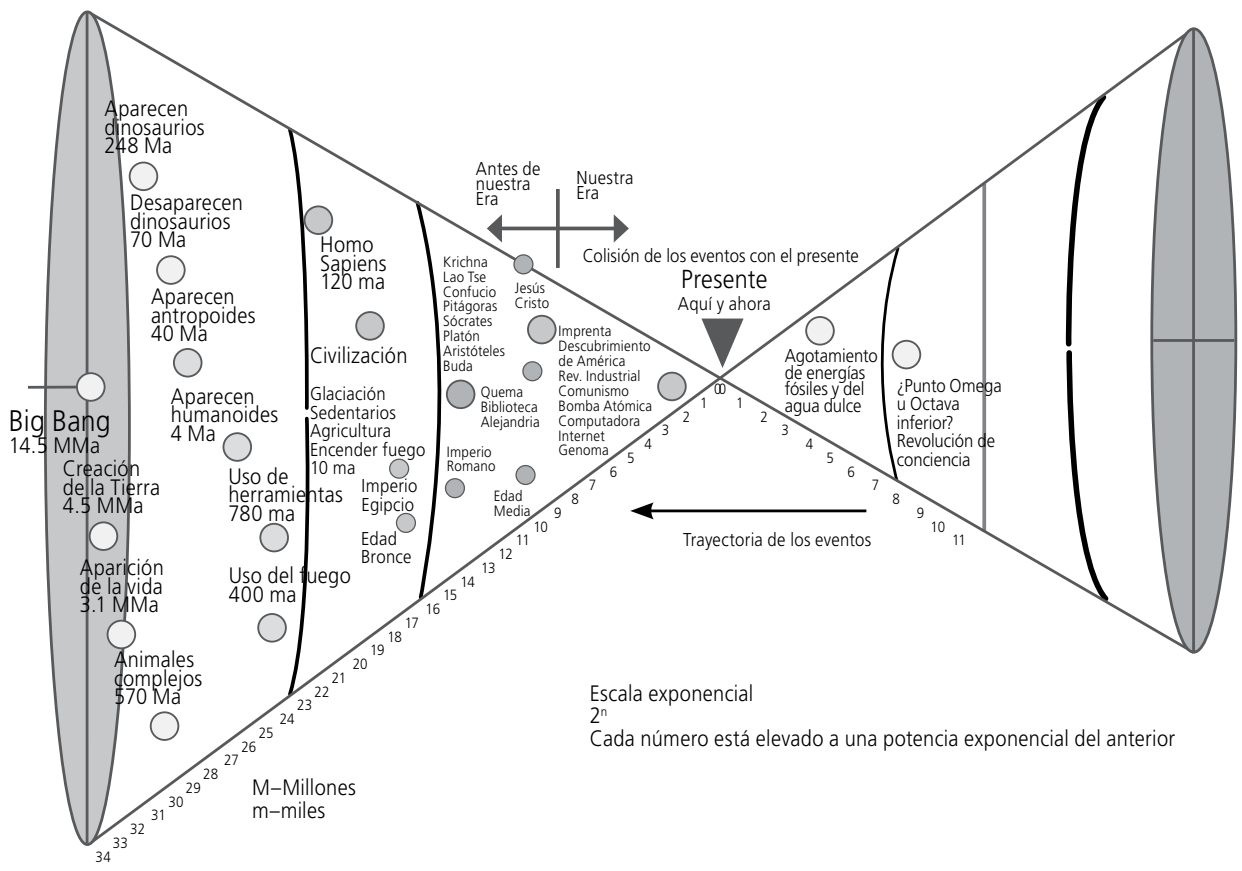

Aquí está representado toda la historia del universo, del planeta tierra, de la naturaleza y del ser humano, tracemos una selección de eventos, aquí tendríamos el Bing Bang, la creación del planeta tierra, la aparición de la vida y los animales más complejos, la aparición de los dinosaurios, aquí aparece el homo sapiens hasta llegar aquí y al ahora, al presente, ya hay unos eventos que se espera que van a ocurrir en el futuro, entonces las navecitas vienen acá del futuro, pasan por el centro del Venturi, y se van hacia el pasado, si es que pasa, porque a veces hacemos que no pase, aquí para poner esto pusimos una escala exponencial de 2 a 1 am, para meter toda la historia del universo en un solo mapa, si le pusiéramos 
una escala lineal, no nos alcanza, toda la pared me la llevo, entonces aquí en el Venturi, cuando estamos viendo el mapa radar estamos viendo el Venturi así (y se coloca las manos hacia la cabeza), cuando lo vemos de lado lo vemos ya tridimensional con los tres tiempos, esta es una propuesta que todavía traemos unos agarrones ahí con los expertos acá de la UNAM, del Politécnico Nacional, etc., ¿cómo es el Venturi?, o sea todavía es una propuesta teórica, por ejemplo aquí tenemos los cuatro tipos de eventos, aquí yo estoy marcado el corto, el mediano y el largo plazo pero hay otras propuestas de otros que ha conocido este llaverito y entonces hay discusiones de cómo hacerlo, y lo que estamos tratando de ver es si lo podemos construir dinámicamente con un instrumento cibernético por ejemplo con flash e incorporarle las tres leyes de Newton porque la prospectiva, o sea estas tres leyes de Newton del movimiento, 1. la ley de la inercia, 2. la ley de la aceleración y 3. la ley de acción-reacción.

MAPA PROSPECTIVO LINEAL SIMPLE (3 LEYES DEL MOVIMIENTO DE NEWTON)

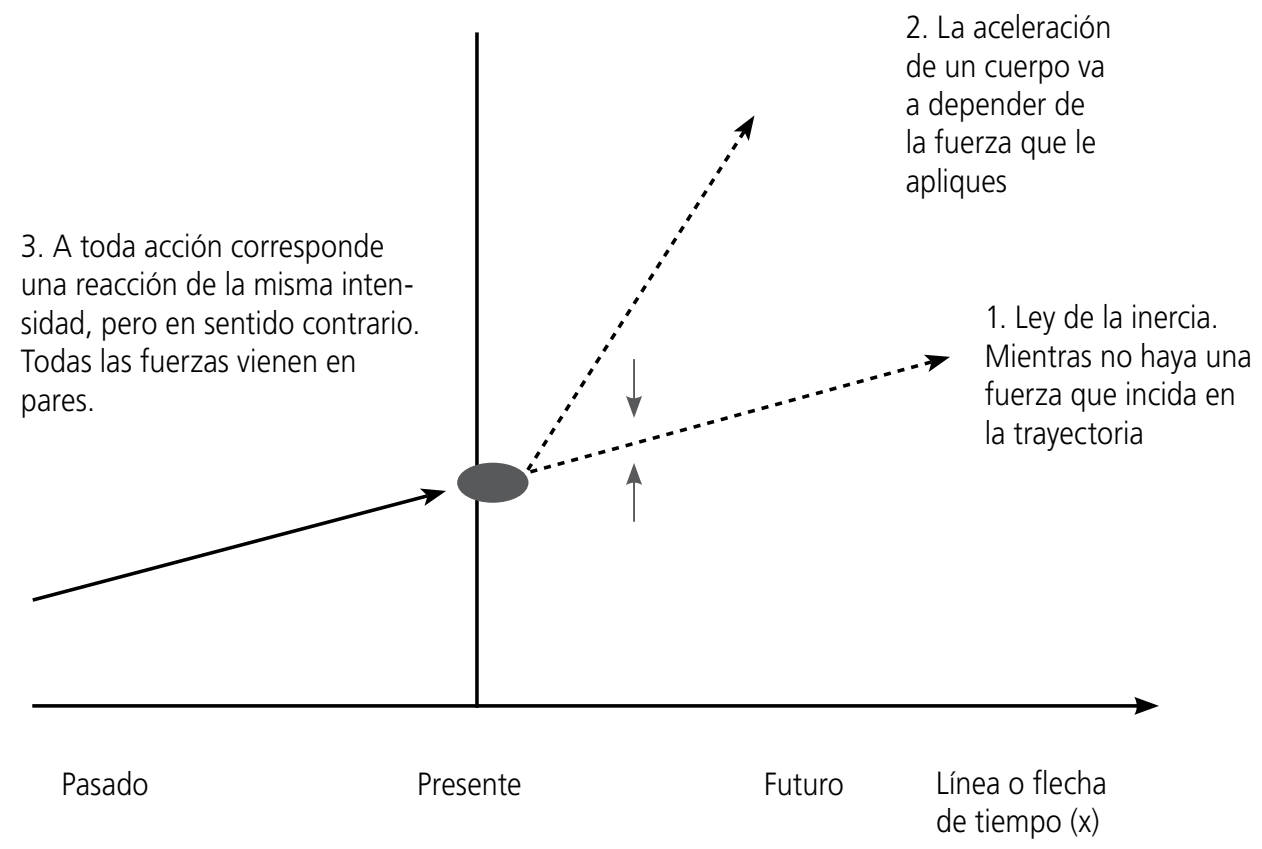


Entonces cuáles de esas naves están sometidas a ese proceso de inercia, de hecho todos los seres humanos, y las empresas y los países somos víctimas de la ley de la inercia, del futuro tendencial, la prospectiva existe porque existe la segunda ley de Newton, la de la fuerza aceleración, a mayor fuerza más aceleración, entonces como yo quiero que se cree este futuro le voy a meter estas fuerzas para que impulsarla.

Pero desgraciadamente existe la tercera ley de Newton, que Newton decía todas las fuerzas vienen en pares, a cada acción va a venir una reacción, si yo quiero crear este futuro algún condenado va a hacer algo para que ese futuro no se cree, es como el cuento ese de la lámpara de Aladino, o sea que van tres negritos y se encuentran la lámpara, ¿ya se lo saben?, la frotan y entonces sale el genio y al primer negrito le dice ¿qué quieres ser? dice blanco, concedido, y le dice al otro, ¿tú qué quieres ser? blanco, concedido y le pregunta al tercero, itú qué quieres ser? que estos dos canijos vuelvan a ser negros, entonces esa es la tercera ley de Newton, tú haces algo para cambiar tu futuro y alguien no quiere o quiere un futuro contrario, tu suegra, tu jefe, eso es lo que le pone sabor a la vida, la hace divertida, o sea tú requieres algo estratégico, si no existiera la tercera ley de Newton existiría la ley del secreto en todo lo que yo quiero se crea, sí, sí se puede crear pero tienes que enfrentar las resistencias.

Entonces es una lucha para crear un futuro, dice un amigo "la vida no es fácil pero puede ser divertida", ¿qué vas a hacer para crearlo y contra qué resistencias te vas a enfrentar?, esa es la parte estratégica, entonces el reto aquí es que construyas tu propio Venturi del tiempo, ¿qué elementos le vas a poner a tu Venturi?, estás aquí, quizás antes no lo conocías, antes de esta sesión, ahora ya conoces este llaverito, ¿cómo voy a jugar con este llaverito que es el que te vas a llevar a Colombia?, ayer me regalaron mi llaverito mi amiga que fue a Colombia, entonces yo les traería un llaverito mexicano para que se lo lleven a Colombia, que es su Venturi, pero ¿qué análisis vas a poner en tu Venturi?, y el reto es que lo puedas construir con flash o cualquier otro programa informático que tenga movimiento, en un caso real que se vaya actualizando día a día y que sea accesible a los tomadores de decisión o sea que lo pueda entender tu jefe, que lo pueda entender tu familia, entonces ¿cómo creo estas naves?

Aquí hay gente que ya ha hecho sus Venturi, por ejemplo Armando, ¿cómo vas con tu tesis? Estamos trabajando. Muy bien pues muchas gracias. 


\section{PROSPECTIVA EN LA GLOBALIZACIÓN, VISIÓN HOLÍSTICA: SERGIO MONTERO OLIVARES}

\section{E}

1 tema que me concierne a mí, va más hacia del ámbito de la provocación, cada una de las exposiciones aquí presentadas son en sí mismas una provocación. Y es cierto que algunos dicen que la prospectiva es una indisciplina, por tanto siempre va a resultar provocadora.

Quiero comenzar poniendo una de las premisas de esta breve lectura, qué es lo que estaríamos pensando con respecto al futuro, y generalmente por las cuestiones retomadas en las ponencias anteriores, es una cuestión que se refiere básicamente al tiempo y al cambio, y le agrego un componente aspiracional: qué piensas, qué es lo que quieres, cuál es tu futuro, y en ese sentido, cuando se dice que ya no hay destino, hay futuro y el futuro es abierto; sin embargo, podríamos decir que en muchos casos hay destino.

Esta situación me puede apartar un poco de lo dicho por el Dr. Tomás Miklos, porque existe el destino cuando decenas de miles de jóvenes que inclusive tienen oportunidad de ingresar al sistema educativo salen al desempleo.

Entonces cuál es el destino de estos jóvenes, cuál es el destino de estos países que han estado siempre colonizados. En ese sentido podemos establecer que la situación del futuro no es meramente de cambio, de tiempo, sino que es una situación fundamentalmente aspiracional, por eso hablamos de la voluntad, del poder y de la creatividad.

El futuro de quién o quiénes estamos hablando, cuáles son los actores; porque los sujetos de la historia, los que realizan la acción, son los que pueden tener la capacidad de transformar. ¿Y cuáles son esos sujetos?

Uno de esos sujetos es el Estado, el Estado-nación con sus diferentes vertientes, y podríamos ver cómo en determinados momentos de la historia, incluso actual- 
mente, impera otro tipo de Estados en algunos lugares de algunas zonas, donde realmente la delincuencia y el crimen organizado es lo que se impone, y entonces, podemos ver que ahí hay otro actor.

Si reconocemos al crimen organizado como uno de los actores que tiene la capacidad de transformar, al grado tal que un estudiante diga: "Yo profesor prefiero ser narco porque cuando menos los narcos son una empresa moderna".

Por otra parte, tenemos a otro de los actores fundamentales: el Mercado, que está imponiendo sus leyes, su dinámica, la urgencia fabricada en donde a través de la competencia y la innovación te hace sentir seguro de nada, porque a través de la obsolescencia planificada, ya no te sirve, una urgencia fabricada demandante de innovación, de lo nuevo, con una rapidez.

Anteriormente trataba el Estado de brindar certidumbre. Cuando se decía que un individuo tiene futuro es porque tenía la posibilidad de ingresar a los sistemas educativos; porque tenía posibilidad de ingresar en el Mercado de tener ciertas reglas que le aseguraban su funcionamiento.

El Mercado no funciona sin el Estado, porque el Mercado es una consecuencia capitalista del Estado capitalista.

Hasta aquí hemos distinguido tres actores y habría que distinguir un cuarto actor, -o los que sean necesarios, los que nuestra creatividad pueda identificar-, y en este caso el cuarto actor es la Sociedad, esa sociedad llamada civil, organizada o en vías de organización.

Ahora bien, pero las reglas del juego ya cambiaron, no están definidas por un sistema internacional que presenta déficit, o un sistema nacional, puesto que los Estados-nación dejaron de ser el eje de acumulación de capital, pasaron de estar como Estados mínimos a Estados inútiles o reconocidos como fallidos o débiles, según su sensibilidad política, junto con toda una debilidad institucional.

Y desde luego, aparte de este mismo Mercado que permea todas estas instancias, donde el Estado asume las prácticas y en vez de una nueva administración pública lo que hay es una nueva gerencia pública, es decir, ya no son administradores públicos como se les conocía propiamente, sino que ahora son gerentes que se dedican básicamente a gestionar o administrar la crisis a través del método incremental, por ejemplo, el sistema judicial tiene que resolver un $85 \%$ de homicidios, pero que comparado con julio de 2013 , con el año pasado en estas mismas fechas, hemos avanzado porque tenemos 20 muertes menos.

Mientras se mantenga en esos rangos no hay mayor problema, entonces, una de las cuestiones que más se ha perdido del Estado, es el gobierno, los dirigentes perdieron su visión de estadistas, de largo plazo, para dedicarse a resolver meramente lo urgente que es impulsado solo por las democracias electoreras. 
Porque cada administración que llega hace su propio proyecto sin visión de largo plazo. A quién le importa el largo plazo, si lo importante es el aquí y el ahora, para eso están los códigos de barras, las compras por internet, la clara expresión de la economía simbólica donde ya no necesitas ver el billete, ahora las transacciones son electrónicas: hemos pasado de un capitalismo productivo, hacia un capitalismo especulativo.

A quién le importa incrementar la parte productiva. Los gobiernos que no tienen visión de largo plazo no tienen programas de economía interna; de fortalecimiento real de sus economías; de alianzas interregionales y de trabajar en el corto, mediano y largo plazo.

\section{CUATRO ESCENARIOS}

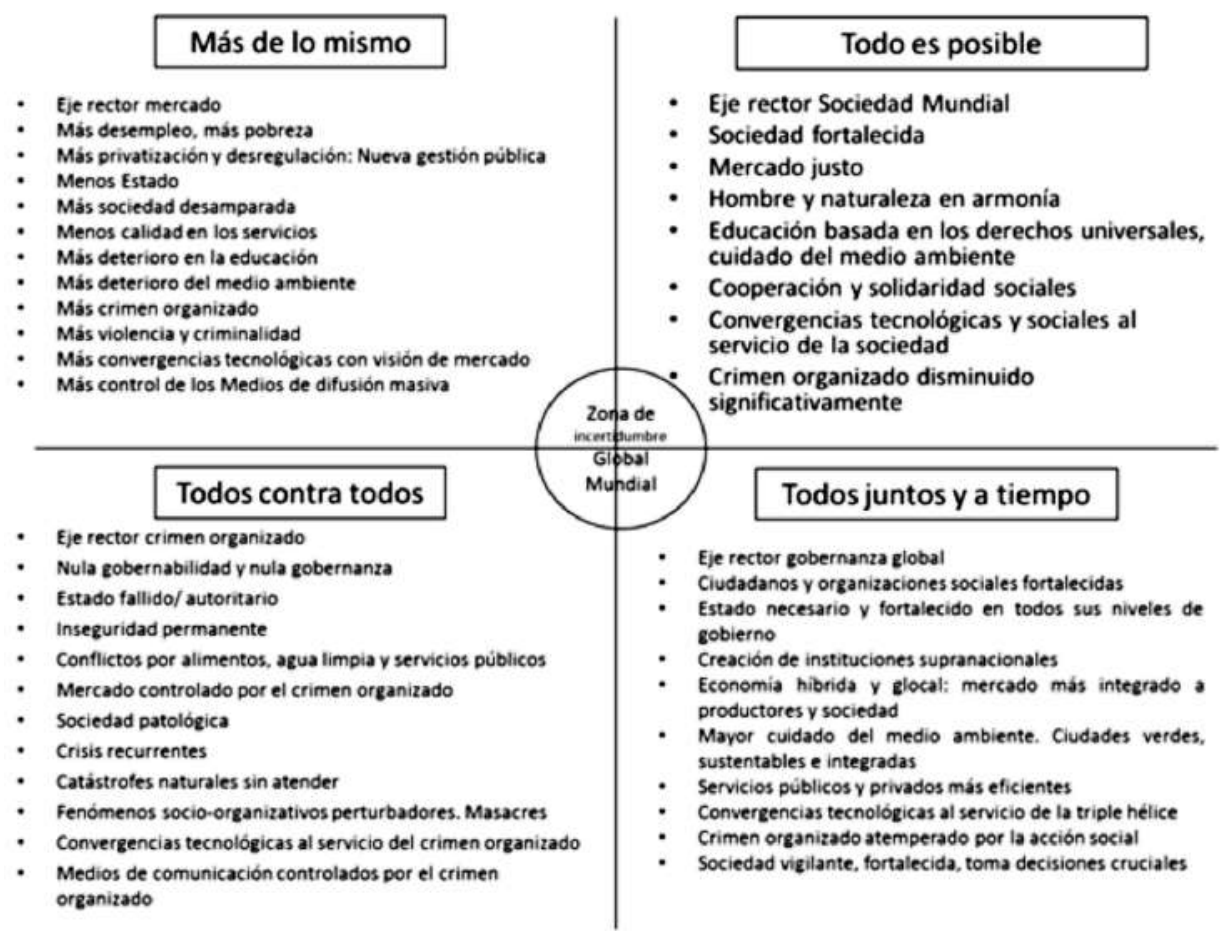

Fuente: Elaboración propia.

Ahora díganme ustedes, con el problema de la delincuencia, se hacen alianzas binacionales, pero el crimen es global, ¿quién detiene el flujo de la venta de armas?, 
es un negocio sumamente rentable, lo mismo se le vende a tiros que troyanos, es decir a los gobiernos y a las guerrillas. Por ejemplo, en México a través del operativo secreto Rápido y furioso, EE.UU. introdujo 20 mil armas y ahora dice no saber dónde están esas armas, pese a que el objetivo era para dar seguimiento a las mismas y, sin embargo, ambos gobiernos ratifican que las relaciones MéxicoEstados Unidos son mejores que nunca, y ello se parece a las estadísticas oficiales que muestran todo, pero menos lo importante.

Las reglas del juego ahora no son sólo globales, sino glocales, por eso la frase de pensar global y actuar local. Pero actuar local con pensamiento global, implica pensar de manera holística y de largo plazo.

Ahora imagínense pensar desde el futuro, suena bien, el único problema es que tienes legisladores, funcionarios públicos y tomadores de decisiones con pensamiento decimonónico, es decir, con pensamiento del siglo XIX, cuando mucho con pensamiento del siglo XX, cómo vas a transformar el futuro si en cada uno de nosotros no se da el cambio, y muchas veces repetimos las resistencias del sistema, por el mismo condicionamiento, por las mismas estructuras.

Siempre se habla de salirse de la caja, sólo que cuando lo intentas, cuidado porque ya eres una persona peligrosa, anti sistémica. Todos los que han propiciado los cambios, son aquellos que no están satisfechos con la situación que tienen, que piensan y quieren tener una situación mejor. Los cambios los hacen quienes aún no están en el área de confort.

Así vamos viendo quiénes construyen el futuro, quiénes lo concretan. En principio, hablamos de un sistema global, y sabemos que muchos Estados no tienen la capacidad para transformar muchas cosas porque las empresas, por ejemplo, una empresa que crea dos mil trabajos, de repente ya no le parece que el gobierno le va a cobrar más impuestos y la va a regular, ahora sí; ¿qué hace?, se va a otro lado y se deslocaliza y no hay un orden internacional que la sujete.

Entonces, qué tiene que haber, de manera muy simple: tiene que haber un orden global, tiene que haber una gobernanza global en lo que se conforma un Estado global, para que haya una legislación global, porque mientras tanto no hay un poder, la política se quedó reducida a lo local. Realmente para que haya esa capacidad de transformación están funcionando organizaciones como Greenpeace, Médicos sin Fronteras, y muchas otras que parten de la sociedad civil. Pero también ya tenemos organismos internacionales que nos han dado el ejemplo de cómo se piensa a largo plazo, un ejemplo, el Fondo Monetario Internacional (FMI) y el Banco Mundial (BM); son organismos creados por los vencedores de la Segunda Guerra Mundial para administrar la deuda, en términos siempre desventajosos para los deudores: te presto, y cuando estés a punto de pagar, te vuelvo a prestar. 
Si queremos realmente buscar soluciones profundas, esas son de largo plazo, no son sexenales, y sí, hay que trabajar, esforzarse y crear una masa crítica, algunos dirían que si es masa no es crítica, pero es masa crítica porque conforma de manera unificada una inteligencia prospectiva. Estamos apenas creando esa inteligencia prospectiva, porque hay un desconocimiento tremendo sobre la prospectiva.

Por ello empieza por la transformación de la mente, y no sólo pugna por salidas, sino por soluciones y sabes que te vas a enfrentar en buena medida al sistema, y si no lo sabes, no vas a tardar en darte cuenta porque te van a cuestionar muchos, simplemente por tratar de hacer las cosas bien. Por ello, la prospectiva, puede decirse, que parece ser sólo de élite, es de personas que realmente están preocupadas, interesadas y ocupadas que haya un futuro. Y para que haya un futuro individual, no puede haberlo si no hay instituciones fuertes entre ellas el Estado. Estados fuertes, no corruptos ni que simulen el ejercicio de la democracia, pero global.

Yo no puedo aceptar a un país que se dice democrático y que con el pretexto de la existencia de armas biológicas invade un país, genera una masacre y después trae a sus empresas para reconstruir el país y explotar sus recursos estratégicos. Ya no lo podemos permitir y se tiene que hablar de ello, pero eso molesta.

Si el Mercado no opera con las reglas, deja la puerta abierta al crimen organizado y pasamos de un esquema ganar/ganar a un perder/perder. Precisamente es lo que Jacques Attali mencionaba como el hiperconflicto, y lo que vemos, por ejemplo, no solamente en Somalia, lo que pasó Colombia y los momentos que está viviendo México, pero con mayor o menor medida o difusión está pasando en todo el mundo. Cada vez el papel de los Estados tiene que ser de mayor cooperación, de mayor colaboración y tenemos que desarrollar empresas y para ser más competitivos debemos aprender a cooperar. Las empresas que ahora están surgiendo son empresas colaborativas y evidentemente ahora con todas estas redes sociales (facebook, tiwtter) pasemos de la cotidianidad publicada en los muros hasta fines de mayor utilidad social. 
TERCERA PARTE

VISIONES ESPECIALIZADAS 
PROSPECTIVA APLICADA AL CAMPO: EDMUNDO AGUILAR

1. i formación viene del mundo de las finanzas, soy financiero; parte de la presentación que verán fue en Michoacán el 21 de junio, presentamos una génesis de prospectiva territorial en la escuela de cuadros del PRI.

El futuro implica un sueño, y la prospectiva territorial implica la construcción de sueños en un territorio determinado. Cuando hablamos de escenarios, recuerden la incertidumbre porque puede pasar lo que no se imagina.

Cuando iniciamos el proyecto de prospectiva territorial en Michoacán en junio de 2013, la persona que apoyaba el proyecto quien fuera gobernador interino, hoy está tras las rejas. Por tanto, no sabemos lo que pueda suceder dado el grado de incertidumbre. Al iniciar los trabajos con los productores, básicamente hay que despertarles un sueño, el sector rural es muy complejo, no creen, han sido engañados muchas veces.

Para ello, les presento un proyecto sobre la tuna, una sola pieza de esta fruta en un mercado de Berlín está en \$2.28 euros. Porque al trabajar con los productores de guayaba tienes que plantear cosas concretas, despertarles un sueño; a lo mejor no a todos, pero con que haya 5,10 o 15, se les despierta este sueño.

Este es el caso de la Guayaba en Canadá, \$.99 centavos de dólar canadiense la pieza; son varios ejemplos para despertar en los productores sus sueños para que tengan un poco de esperanza: Y bueno ahora sí, mis productores, los hijos de la guayaba, en la visión de largo plazo hay que pasar a la acción, tenemos tiempo pero no mucho, debemos pasar a la acción, en mi experiencia es así: debemos pasar a la acción. 


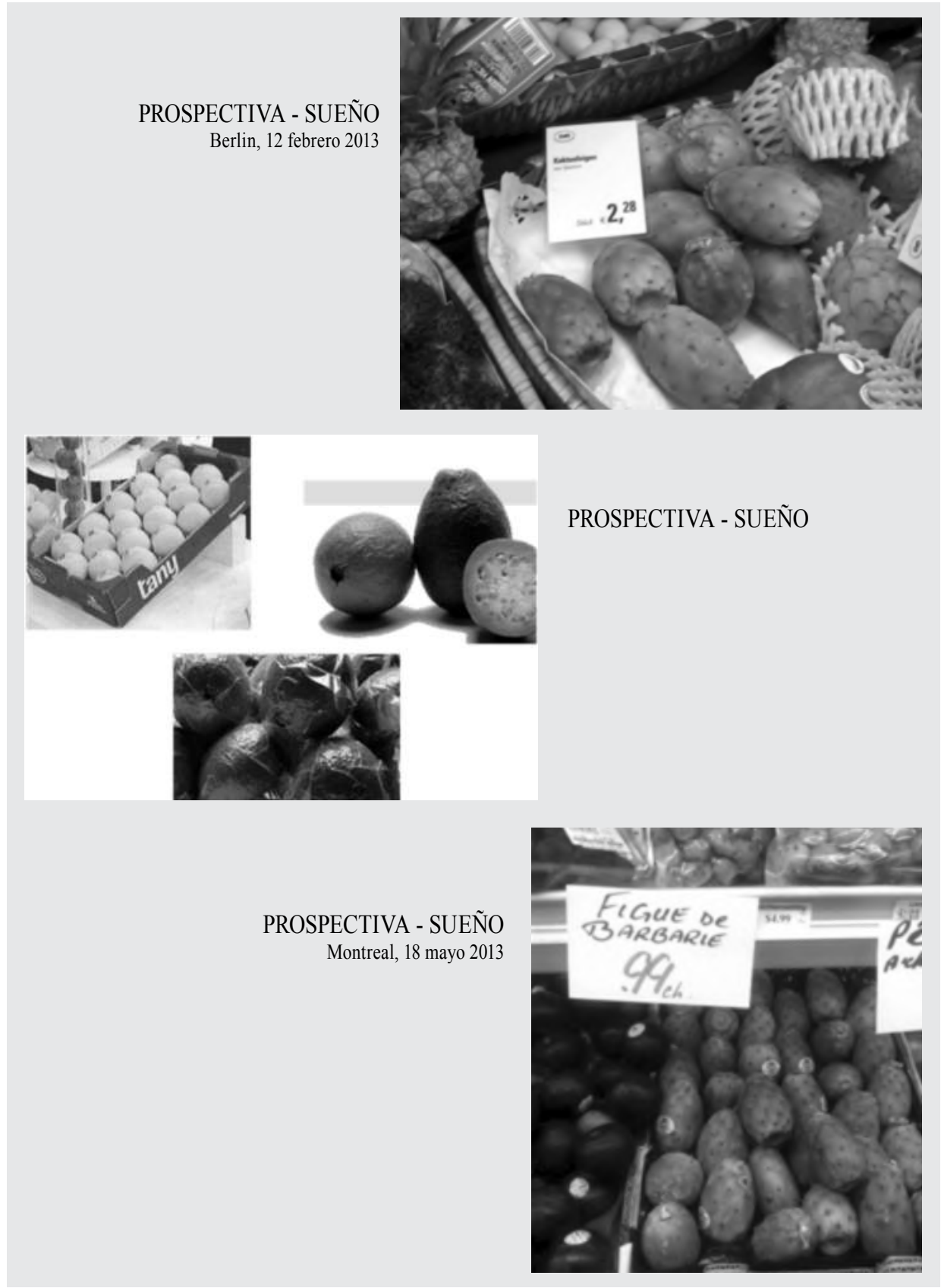


Entonces, empezamos con nuestros productos a ver el futuro, esta fruta (la guayaba) viene de países como Brasil, Colombia, Sudáfrica, Egipto y la India llegan a Europa y Canadá, y a partir de ello pasamos a un proyecto de prospectiva territorial. Pero para que esto sucediere tuvo que pasar un año, donde estuve trabajando en Michoacán, en cuatro municipios, donde se concentra el 60\% de la producción de guayaba en México.

\section{LA PRODUCCIÓN MUNDIAL DE GUAYABA}

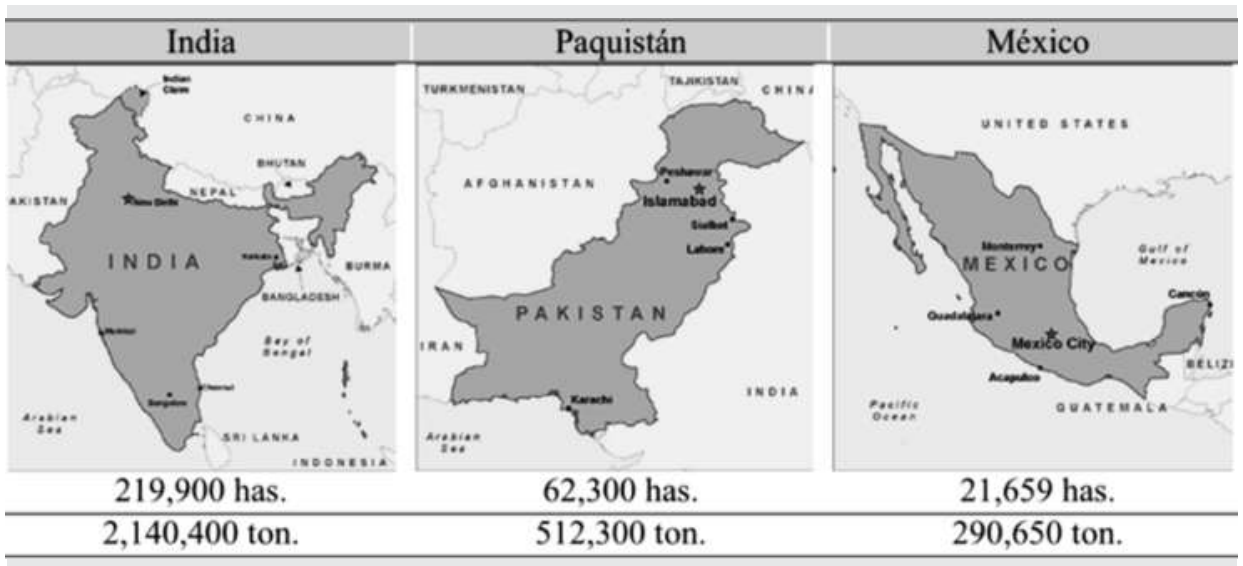

Todo comienza en el campo, donde tenemos mujeres, niños y pocos hombres, y es eso lo que sostiene el sector rural; también hay jóvenes, pocos pero los hay, mientras recorríamos las huertas uno les pregunta cómo ven el futuro, y sin duda la imagen es distinta.

Tres pilares son de la prospectiva: la anticipación, la apropiación y la acción. Sin embargo, no todo se da al mismo tiempo. La prospectiva en los territorios es de más largo plazo, para llegar a una guayaba, antes tuvo que plantarse un árbol. Michoacán no es el estado originario donde nació como actividad la producción de guayaba; se dio por una o dos personas que llevaron la guayaba al estado, y hoy es ahí donde se da la producción de esta fruta en México.

En el campo nuestros productores con los que estamos trabajando, ya tienen una visión al 2030, en el corto plazo (ámbito municipal), mediano plazo (nivel estatal) y en el largo plazo, con 10 años; a nivel nacional de estar trabajando en el caso de la guayaba concretamente. 


\section{CÓMO HACERLA Y POR QUÉ HACERLA}

Un territorio es muy complejo, hablamos de miles de actores, porque los prospectivistas no nos damos el tiempo para estar con los productores en el largo plazo; eso toma tiempo. La guayaba es principalmente de Centroamérica, Colombia, México, Brasil. Pero a nivel mundial los actores centrales en la producción de guayaba son: la India, Pakistán y México; sin embargo, ninguno de los tres países es líder en la comercialización de la guayaba.

Hay un detonador del mercado que incentive el consumo de guayaba, y es el aporte de vitamina $C$, la guayaba es mucho más rica en vitamina $C$ que los cítricos, tres o cincos veces, y un poco más que el kiwi y baja en calorías. Así, el argumento de Sudáfrica al comercializar la guayaba es colocar la fruta que más vitamina C tiene, en otros países. Dos guayabas en ayunas te sacian el apetito.

Lo difícil, es construir un proyecto en común de cuatro municipios diferentes; es decir, cómo le hacemos, para que los actores centrales que son los productores se apropien del proyecto. Tenemos grandes problemas dentro del sistema rural, distinguir lo complicado y lo complejo, debemos identificar las variables, los actores clave.

Lo difícil del campo es que los actores requeridos no siempre se encuentran en el lugar, trabajar en la prospectiva territorial en el sector del campo es muy complicado. Hay en la primera reunión 2 mil productores; cómo le hacemos para establecer un diálogo y un contacto con los 2 mil productores; en la segunda reunión hay mil productores, para la tercera reunión tenemos 400, para la cuarta están 20 y culminamos sólo con 5 , que son los que no tuvieron nada qué hacer.

A ello hay que agregar la carencia de masa crítica, los productores temporales y lo difícil de ubicar a los líderes clave dentro del campo, para que esto forme masa crítica, en la escala del tiempo cuando ellos tienen tiempo yo no lo tengo, y cuando yo tengo tiempo ellos no tienen el tiempo, entonces, también poder encontrar las intersecciones.

Ahora bien, al pasar a los escenarios exploratorios, en el caso de la guayaba ésta nació, en nuestro país en el estado de Aguascalientes, donde por el clima no hay agua, los suelos son pobres, la parte industrial es más importante. Así dos personas externas a Michoacán vieron que se daba guayaba cuando no era temporada por lo cual decidieron plantar guayabas en su estado y fueron estos visionarios los que se necesitaron. Quién más debería estar, bueno los gobiernos municipales; el gobierno estatal, el gobierno federal, las Secretarías de agricultura; economía, etc. Es muy difícil empatar tiempos distintos bajos los cuales se mueven los distintos niveles de gobierno. En estos cuatro municipios michoacanos (Hungapeo, Juárez, 
Zitácuaro) es la guayaba el hilo conductor de la prospectiva territorial, hablamos de 7 mil productores, donde el 95\% de la población vive de la producción de guayaba, hoy trabajamos con 11 líderes que representan a 2 mil productores, o sea el 2\% de la producción nacional, con 250 hectáreas de cultivo, 500 empleos, una derrama económica de 20 millones de pesos.

Los gobiernos municipales sólo han aportado 20 anuncios espectaculares sobre las carreteras haciendo referencia a Hungapeo como capital mundial de la guayaba. Qué decir del dispendio de los 2 a 4 millones de pesos anuales que gastan para colocar por quince días una pista de hielo, con esos recursos en estos 10 años podrían haber construido ya toda una agroindustria.

Pero los gobiernos municipales son sólo un actor más con agendas específicas y que responden a partidos específicos, su visión dura sólo 3 años. En el área encontramos infraestructura que no se ocupa, por ejemplo una procesadora de mango, siendo que no hay mango, se construyó en los albores del Programa Nacional de Solidaridad (Pronasol), hoy forma parte del proyecto de prospectiva territorial para la guayaba. Asimismo, tenemos este nuevo formato terminal de guayaba, donde las semillas son un obstáculo para quien no la ha consumido en su vida o le molestan las semillas.

\section{FUTURO UN POCO MÁS CERCANO}

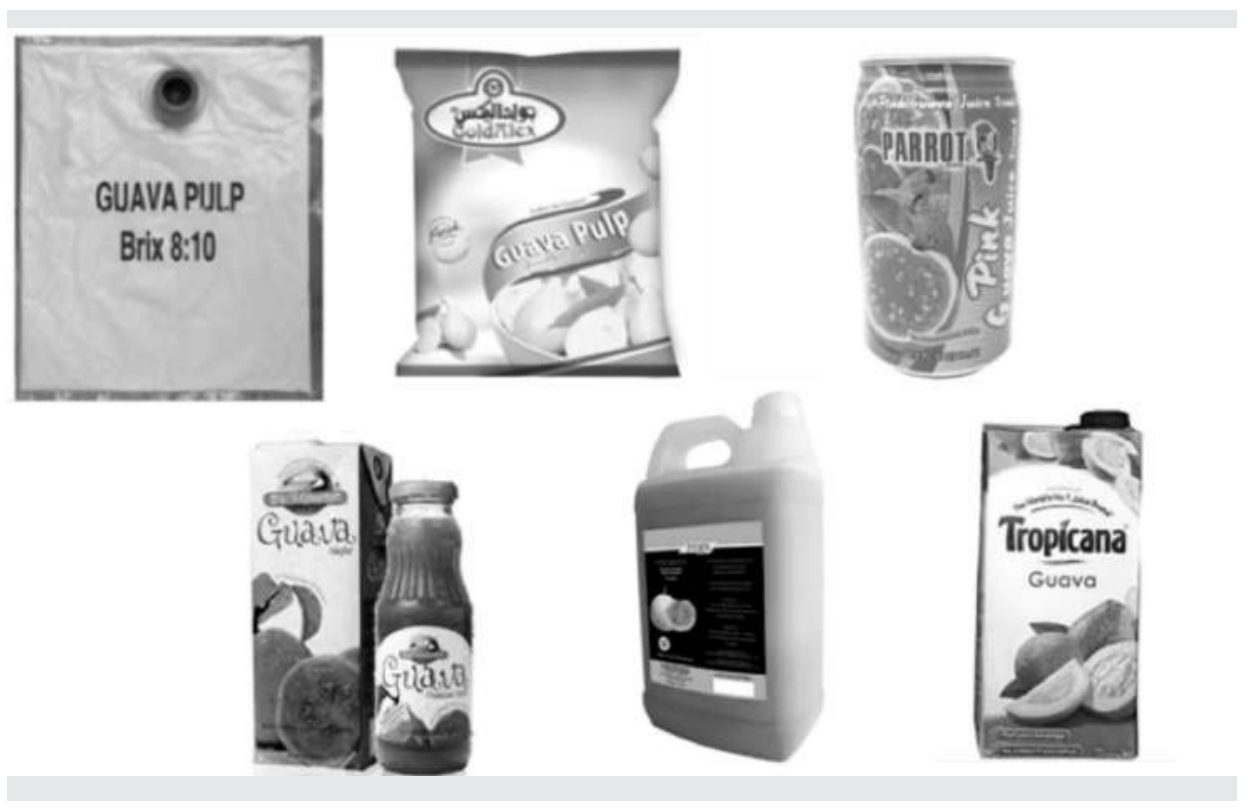


También se han iniciado procesos para echar a andar procesamiento de guayaba para exportarla como pulpa, en los lugares donde no pueda llegar fresca.

La experiencia en el sector rural, básicamente es que todo empieza con los talleres, donde las personas se empiezan a involucrar, lo importante del taller no es lo que resulta, sino el proceso del taller, es lo que hace interesante a la prospectiva. Asimismo el uso de los métodos, viene la duda de cómo aplicarlos en el campo con población, incluso analfabeta. El world café es una buena metodología para acercar al productor, para que éste se sienta parte del proceso.

\section{USO DE MÉTODOS}

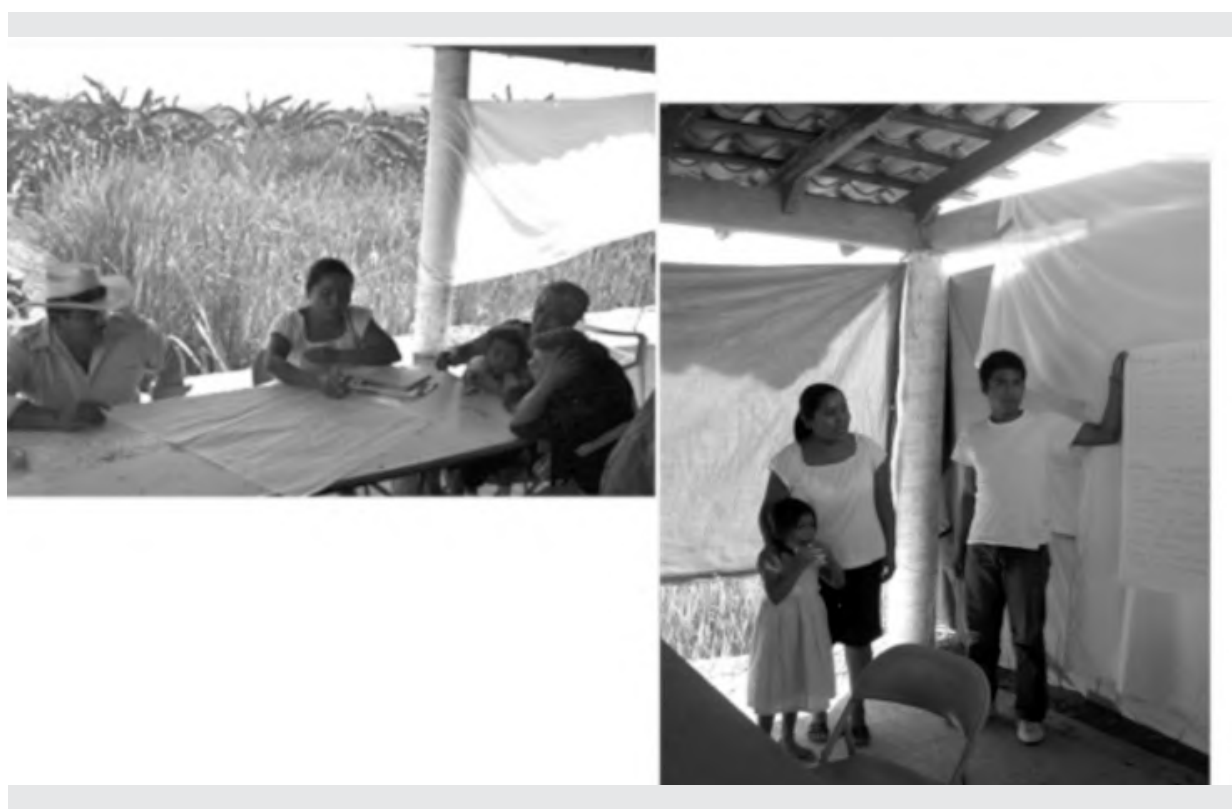

Algo que es importantísimo es detectar las posibles oportunidades si no tenemos ejemplos concretos de la aplicación de la prospectiva en un nuevo lugar; cuando yo llegué al caso de la guayaba fue por invitación de un curso que daba con productores de tuna amarilla y roja que son las que se consumen en el mercado de exportación.

De nada sirve llegar con la cajita de herramientas de Godet, si no se tienen ejemplos concretos, ayuda mucho mostrar ejemplos concretos sobre lo que hace la prospectiva, para ello es la anticipación. Si uno no anticipa algo que nos va a servir dentro de cinco años. 


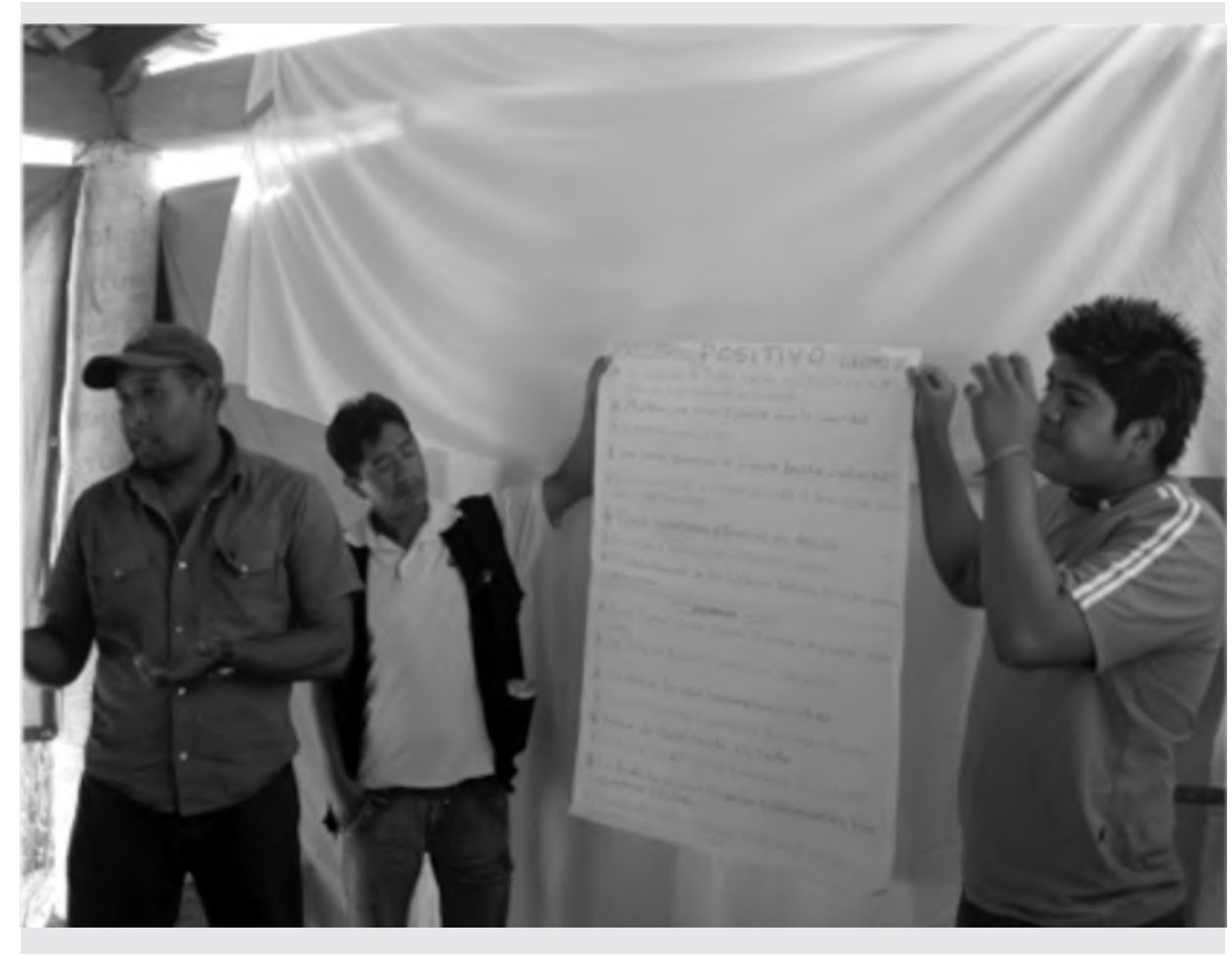

También son importantes las alianzas claves en prospectiva, en México cada seis años, cada secretario de agricultura trae su idea sobre lo que debe ser la agricultura; las instituciones gubernamentales no tienen planeación, tienen ideas que duran seis años, lo que las personas duran en su cargo. A veces la clave, al final, es a quien conoce uno que les puede servir a ellos.

El know how, pero también es importante el saber ser, antes que el saber hacer, es mucho más importante, con quién vamos a trabajar, este proyecto es de largo plazo.

Innerarity, señala a los enemigos del futuro aquí son los causantes del hambre y la desnutrición que asolan al campo mexicano. Es increíble que la gente se esté muriendo de hambre, cuando con tres guayabas ya tiene cubierta su ingesta nutricional básica; falta de agua potable, enfermedades gastrointestinales que causan la muerte cuando tres guayabas; un jugo de guayaba; pulpa de guayaba o un té de guayaba es buenísimo para combatir infecciones estomacales. 
Medio ambiente. La agricultura consume a nivel mundial el $80 \%$ del agua potable, se desperdicia; la contaminación por pesticidas; gente desnutrida implica personas que tendrán baja productividad y desarrollo intelectual.

Por ello el reto es ahora, cómo hacer que a los políticos les interese; su visión del sector rural a tres años, por ello son los enemigos del futuro. En los siguientes 50 años tendremos que generar una producción agrícola a la equivalente de la que la humanidad produjo durante los últimos 10 mil años, cuando seremos cerca de 10 mil millones de personas en el mundo.

Lo más importante es lo que yo hago como consumidor, esto no es personal sino estrictamente negocios, pero en el campo todo es personal, siendo así lo complicado por encima de lo complejo. Sí se pueden hacer cosas en el campo, pero ello lleva tiempo y esfuerzo.

La base de un proceso de prospectiva territorial en el campo siempre son los productores, y ellos; necesitan de líderes que son la gente clave que va a presionar al gobierno, porque siempre el que grita más, el que tiene más poder, el que tiene más interés, es el que representa a cada uno de los sistemas productivos del campo ante el gobierno.

Hay serias deficiencias en la vinculación con las universidades, por ejemplo, en la ciudad los egresados de comercio internacional se quejan de no tener fuentes de empleo porque quieren trabajar en la Ciudad de México, en Nueva York, mientras el campo carece y está urgido de ellos. 


\section{PROSPECTIVA CIENTÍFICO-TECNOLÓGICA EN MÉXICO: FRANCISCO SORIA VILLEGAS}

NOTA: Esta charla se desarrolló en una visita a la Facultad de Ingeniería donde se presentaron datos sobre la UNAM y el papel de la ciencia y la tecnología que desarrolla la Facultad de Ingeniería así como la aplicación prospectiva a lo largo de sus planes de estudio. La charla fue también complementada por el Doctor José Francisco García Ugalde, Jefe de la División de Ingeniería Eléctrica.

rimero, debo agradecer a todos ustedes su asistencia aquí a las instalaciones del Posgrado de la Facultad de Ingeniería de la UNAM, nos da muchísimo gusto que visitantes extranjeros puedan compartir con nosotros parte de los conocimientos de los desarrollos tecnológicos que hemos tenido aquí, con nosotros.

Por una parte me parece importante situarnos en la Universidad. Nuestra Universidad tiene instalaciones en 16 entidades federativas, en la mitad del país, y todas tienen alrededor de 105 carreras de licenciatura, posgrados y lo que se refiere a especializaciones, a maestrías y a doctorados, que tiene una planta académica amplia. En el caso de la Facultad de Ingeniería tenemos 256 profesores de tiempo completo, tenemos en licenciatura 12,500 alumnos y en posgrado tenemos, o sea en lo que es especializaciones, maestrías, doctorados alrededor de 1,500 alumnos también, entonces es una universidad muy, muy grande y bueno, desde luego algunos de ustedes ya tienen alguna idea de la magnitud de ésta.

Me he dedicado estos dos años anteriores a estudiar algunas cuestiones sobre materiales, sobre vehículos de transportes, sobre la vida en el espacio, pero voy a mezclar con algunas otras cuestiones más aterrizadas en el territorio nacional y en el desarrollo económico de nuestro país.

Puntualmente las funciones que nosotros tenemos en la Facultad de Ingeniería en un contexto global, en un contexto en donde la nación está interviniendo para un proceso de cambio permanente, tal es el caso de las reformas, tal es el caso de nuevos planes de estudio, tal es el caso de nuevos proyectos de investigación, de los cuales platicaremos un poquito. 
Tenemos varios invitados, está con nosotros por el momento la maestra Silvina Hernández García que es la responsable de la carrera de Ingeniería Industrial, que más tarde nos comentará algunos aspectos relacionados con esta visión del año 2020, de los cambios de planes de estudio en ingeniería industrial y algunas cuestiones específicas de incubadoras de empresas y de esta cuestión relacionada con la vinculación entre la Universidad, particularmente los proyectos de ingeniería y las empresas nacionales desde PYMES, hasta muy grandes.

Yo les platicaré algún proyecto interesante que tuvimos con Petróleos Mexicanos que es una de las empresas desde luego ustedes han de conocer, más importantes del país, la primera empresa exportadora, con una producción de más de 2 millones y medio de barriles diarios de petróleo, pero que además tiene procesos de producción muy interesantes, desde localización de mantos petroleros hasta la explotación de ellos. Hicimos una especialización que se aprobó y que además es una modalidad interesante que es educación a distancia.

Bueno, particularmente voy a hablar de indicadores claves de desempeño. Hay una gran cantidad de indicadores claves de desempeño, algunos de ellos los vamos a trabajar y realmente daremos un paso desde la historia, el estado actual y algunas perspectivas que nosotros estamos trabajando aquí en la Facultad de Ingeniería, que es lo que vamos a tratar, Se muestran 4 indicadores claves de desempeño que tienen que ver por una parte 1) con la protección intelectual, 2) con el desarrollo particularmente de patentes, 3) de nuevas manufacturas, 4) de nuevos desarrollos tecnológicos, de innovación, esa es una parte que guarda gran interés para nosotros.

La otra cuestión está relacionada con cuál es el ámbito internacional, como están las empresas multinacionales de las cuales ustedes verán que algunas de ellas son conocidas en Colombia, son conocidas en Brasil, son conocidas en Argentina, son conocidas en Ecuador, son conocidas en México, en Estados Unidos, en Francia, en Alemania, son de carácter general y se han mantenido a lo largo del tiempo y algunas empresas nacionales que se han mantenido también porque las competencias han sido de verdad cada día más difíciles en términos de la producción y en términos de las competencias.

Los ciclos son cada día más cortos y las competencias son cada día más abiertas y globales, la parte de educación, donde nos situamos las universidades, porque de repente pues uno puede pensar muchas cuestiones, en las bondades que tiene la formación de los egresados y esta cuestión de cambio social en términos de los beneficios de la formación y de la actividad profesional que tenemos de cada uno de nuestros egresados y del gran prestigio que éstos llevan consigo en nombre de las instituciones, porque son etiquetados, de dónde son egresados y los cambios que producen socialmente. 
Entonces dónde estamos en este contexto internacional y nacional, en el caso de la UNAM, de esta universidad, es la mejor universidad de este país, no porque yo lo diga, se hace más del 50\% de la investigación y desarrollo y en realidad la cantidad de egresados que tenemos en todas las disciplinas está contribuyendo al cambio del país.

La otra cuestión que también es interesante es qué estamos haciendo para mejorar y modificar los planes de estudio y las características propias de nuestros egresados asociados a los perfiles que tenemos establecidos, nos van a platicar al ratito de una nueva carrera, una nueva carrera que está en transición y que tiene que ver con la convergencia de saberes, o sea no la forma tradicional de trabajar las carreras de ingeniería, sino una forma diferenciada de tener un avance tecnológico que para los siguientes años va a tener una repercusión importante, no solamente en este país, y bueno pues platicaremos algunas otras cuestiones de tecnología y de asociaciones relacionadas con algunos proyectos como los proyectos matriculados.

Veamos el caso de algunas de las empresas que quizá para ustedes sean conocidas, en primer lugar Bayer que es una empresa alemana de origen, pero que se ha mantenido desde hace más de 100 años y de repente pues cuando alguien plantea las buenas prácticas, los buenos desarrollos, los buenos productos, la verdad es que se han mantenido a lo largo del tiempo y ha tenido una serie de cambios importantes de desarrollo, tiene edificios de investigaciones y desarrollo en nuevos productos que se vienen incorporando en los siguientes años, pero consideren la fecha de inicio de Bayer, y así tenemos a Siemens, también que es muy conocida por ustedes, nosotros tenemos en el país varias empresas de Siemens que producen algunos de los productos que se venden no solamente dentro del país sino también se exportan. Kodak, o sea la parte de fotografía que también está teniendo cambios importantes desde las tradicionales cámaras hasta los nuevos enfoques que tenemos basados en microchips que tienen funciones totalmente diferentes.

Bueno también mencionamos a la cervecería Cuauhtémoc que de origen era mexicana y ahorita ya tiene participación de algunos extranjeros. La vidriería Monterrey que es una empresa muy importante que tiene que ver con Monterrey que es una región de desarrollos importantes y que tiene que ver también con el Grupo Vitro, ¿qué tiene este grupo en particular? tiene más del 50\% del mercado de vidrio en Estados Unidos de Norteamérica, y bueno, está la General Electric que también es una empresa importante que recibe algunos de nuestros egresados y los prepara para cuestiones de investigaciones y desarrollo y las empresas automotrices que son de las grandes oportunidades que nuestro país tiene para desarrollar tecnología. 
Tenemos muchas empresas automotrices que exportan no solamente a Estados Unidos sino a algunos otros países y que son las oportunidades de diseño que tenemos y bueno, hay algunas otras más, Mabe que también es conocido de ustedes, tiene también empresas en América del Sur y en Estados Unidos de Norteamérica en diseños de electrodomésticos, o sea me refiero a estufas, refrigeradores, lavadoras y que ha tenido un impacto muy fuerte en el desarrollo, tiene proyectos también de vinculación con nosotros y es una empresa importante para el país y bueno, hay algunas otras como Sony, aquí Sergio Montero decía en alguna ocasión ¿quién no tiene un Sony?

Son empresas que se han mantenido en todo el mundo en forma tal que el impacto de los productos son realmente, los que han invadido todos los países; Samsung, Apple, ésta es una Macintosh también eh, bueno, en economía dentro del país.

Las empresas más importantes son las de servicios, pero estas empresas importantes de servicios son fundamentalmente bancos, fundamentalmente venta de artículos, pero no es la cuestión de empresas de creación de nuevos productos o de innovaciones También son claves las exportadoras, la primera exportadora importante de este país, de nuevo es Petróleos Mexicanos, ahorita está en una serie de reformas importantes pero la repercusión de esas reformas se verán en los siguientes años, nosotros esperamos que, (es uno de los resultados que el gobierno mexicano espera que tengamos) la sociedad mexicana tenga un desarrollo distinto al que ha tenido en estas décadas anteriores, puntualmente en estos 20 años anteriores de desarrollo porque tuvimos un auge, que le llamaron el milagro mexicano y que tiene que ver con un auge de un incremento del PIB anual que sobrepasaba al $5 \%$, el promedio del $6 \%$ del PIB y que esperamos para los siguientes años con todas estas reformas vaya modificándose, incrementándose esto.

Esto no solamente tiene repercusión en la parte económica, sino tiene repercusión en la parte de empleo, tiene una repercusión importante en la cuestión de la formación de quiénes van a formar los cuadros de desarrollo tecnológico del país. Y las empresas que aparecen aquí en su mayor parte son Volkswagen y General Motors, empresas automotrices, tenemos una gran cantidad de ellas, son una inversión muy, muy fuerte dentro del país, entonces son oportunidades que tenemos para el desarrollo de tecnología, en esta parte importante, desde luego también tenemos la parte de robótica, la parte de nuevos materiales, la parte de convergencia de saberes, puntualmente la asociación de tecnología con la parte de los médicos en las cuestiones estructurales del ADN de estas formaciones de guanina, citocina, adenina, timina, el rompimiento de las cadenas de producción en relación a organismos genéticamente modificados y a la clonación, que ustedes ya han escuchado un poco de eso. 
La cuestión de las patentes, ha sido una parte importante, en México tenemos solicitudes de patentes: 14,000 solicitudes de patentes anuales de las cuales no todas se consiguen, pero sí tenemos más o menos un promedio de esta cantidad. En Japón que es uno de los países de vanguardia se tienen 200,000 solicitudes de patentes anuales, o sea la diferencia es abismal y de alguna manera me parece que en los países como México la dependencia tecnológica se continúa dando en este camino, de éstas 14,000 de solicitudes anuales que tenemos en el país el 95\% son de extranjeros, o sea de compañías y de personas extranjeras que solicitan la patente en el país y esto pareciera que no tiene importancia, pero en el fondo dependemos de quienes tienen estas capacidades de desarrollo y de plantear las alternativas de solicitudes de patentes y en el caso de países como Japón, el 95\% de las patentes son solicitadas por nacionales japoneses, entonces de nuevo las diferencias son abismales.

Una de las cuestiones que nosotros pretendemos aquí en la Facultad de Ingeniería es incrementar la capacidad de quienes están formándose aquí desde la licenciatura hasta el posgrado, con grandes capacidades de cambio, de innovación, y una parte de ellas serían las patentes, entonces, a pesar de que la cantidad de patentes ha ido creciendo con el tiempo, Japón sigue siendo una parte importante de comparación con lo que sucede en el mundo en la parte tecnológica y en la parte de Educación Superior.

Hay una relación importante en la parte de formación educativa de las licenciaturas y en los posgrados en desarrollo tecnológico y el PIB, de hecho en alguna publicación colombiana me pareció interesante cómo correlacionan el PIB con el desarrollo tecnológico y aquí aparecen dos grandes partes de algunos países que son conocidos por nosotros, entonces la educación, el desarrollo tecnológico y el PIB están ligados de una forma importante, esto pues hace conciencia para que podamos trabajar más en la parte de desarrollo tecnológico, no como tal, sino también con la integración de saberes y particularmente con el beneficio de la sociedad, el beneficio social de quienes integran cada uno de nuestros países en un contexto de globalización.

China es un país que debe analizarse desde varios puntos de vista, desde el que vemos desde afuera, con un PIB creciente arriba del $8 \%$ anual a lo largo de más de 10 años, pero también con una población creciente de más de 1,300 millones y otros factores que a veces no se analizan; sin embargo, en la parte tecnológica están trabajando de una manera tal que están atrayendo extranjeros chinos, o sea que residen fuera de China, y ya tienen nacionalidades donde ya no son chinos, pagándoles sueldos muy altos en un desarrollo de la Cuenca del Pacífico de verdad 
sorprendente en la parte tecnológica, y están entrando en la parte de patentes de una manera distinta a la que se había dado en el pasado, ya no es la parte de los chinos en donde se comparten todos los desarrollos tecnológicos de las empresas europeas, o de las empresas de Estados Unidos o de otras partes del mundo que van a residir a China, sino están creando ellos una base tecnológica de desarrollo a través de las patentes y esto está teniendo un impacto muy, muy importante. Bueno, en menor proporción tenemos a Brasil, que es uno de los países en América Latina que tiene desarrollos importantes, de hecho es uno de los países de economías emergentes importantes junto con Rusia, Sudáfrica, India y China.

Pero de todos esos, China, para el año 2050, se espera que tenga un desarrollo tecnológico y una economía realmente de vanguardia en el mundo en comparación de Estados Unidos de Norteamérica que a pesar de mucho de lo que se dice continúan siendo importantes en la parte de desarrollo tecnológico, y en la parte de producción, exportación y atracción de sobre todo de inversiones extranjeras Aquí hay una lámina interesante que dice galaxia de conocimientos de impacto mundial y tiene que ver mucho con la formación sobre todo de los posgraduados, hasta donde nuestros posgraduados, en el caso de México, en el caso de Brasil, en el caso de otros países, tienen impactos mundiales realmente de fuerza tal que puedan cambiar los usos y costumbres de la sociedad, así como son los celulares, así como son las Macintosh, así como son las nuevas telecomunicaciones en términos de la comunicación instantánea, internet u otros medios de información.

¿Hasta dónde la mayor parte de nuestros egresados en términos de maestrías y doctorados realmente hacen una función importante de cambio?, algunos de ellos en el caso de México, tenemos en el Sistema Nacional de Investigadores unos 18,500 que pertenecen a este Sistema, pero lo que se evalúa fundamentalmente son publicaciones indexadas internacionales, libros y realmente una relevancia más bien teórica que realmente dé aportación a la sociedad en cuanto a los desarrollos tecnológicos que se pueden incorporar a ésta.

Entonces, bueno, aquí hay una comparación interesante también, en relación con este contexto internacional de los rankings, algunos opinan que estos rankings están hechos por quienes tienen los primeros lugares, sobre todo las Universidades de Estados Unidos, como Yale, Stanford, pero nos dan indicadores de cómo estamos también, en el caso de la Universidad Nacional Autónoma de México hay quienes opinan que los indicadores de estos ranking fundamentalmente no obedecen realmente al contexto social en donde están las universidades latinoamericanas y ha habido reuniones en las cuales se han cuestionado estos rankings, pero independientemente de quien cuestiona todo esto, esta comparación de cómo estamos en un contexto 
global y mundial es importante, cómo está la Universidad Nacional Autónoma de México en este contexto mundial, y sí, estamos dentro de las 200 universidades en un rango de 2,000, bueno de más de 1,000 universidades del mundo evaluadas.

En el caso de ciencia y tecnología andamos alrededor de las 100 universidades más importantes, pero nos falta trabajar mucho más en esto, nos falta un desarrollo tecnológico mucho más important.

En México la ciencia y la tecnología, ¿cómo estamos en el contexto nacional?, bueno existen algunos puntos importantes, como el Plan Nacional de Desarrollo, como la cuestión asociada a los sectores de desarrollo del país y fundamentalmente quienes promueven la ciencia y la tecnología en México es el CONACYT. Y el CONACYT tiene que ver con el desarrollo de la tecnología en el país, pero tiene que ver también con la cuestión de la formación de los posgraduados dentro y fuera del país, o sea los que están becados en el exterior y regresan con nosotros y los que están formándose aquí, hay posgrados de calidad que también están realmente sostenidos en gran parte por las becas que CONACYT da a nuestros alumnos y desarrollos realmente en el Plan Nacional, cómo es el caso de las coordinaciones de vinculación en todas las universidades que tienen que ver con esta cuestión, no solamente del desarrollo tecnológico y cómo las universidades pueden ayudar a colaborar a las empresas para desarrollar tecnología dentro del país

La Organización para la Cooperación y el Desarrollo Económico, expone datos sobre lo que estamos dedicando nosotros a los recursos humanos de alto nivel, o sea desde aquellos egresados especialistas, los que han egresado de especializaciones, de maestrías y doctorados en todo el país, Cada uno sigue una línea de investigación diferente o hay grupos de ellos que están realmente trabajando para el desarrollo del país a mediano y a largo plazo, para la formación de recursos humanos y de soluciones alternativas para nuevos productos y procesos.

En la información de la Organización para la Cooperación y el Desarrollo Económico, aparece lo que entienden ellos por alta tecnología y dentro de la alta tecnología están algunas de las cuestiones de exploración espacial, que eso es sorprendente, en el caso de México, si tenemos algunos satélites de exploración, de monitoreo, de variable para la temperatura o de edad, partículas, pero no tenemos hasta ahorita un desarrollo tecnológico importante en relación con la construcción de plataformas, los chinos ya tienen alguna de ellas o como la NASA que tiene ya la exploración hasta Marte y otros planetas del sistema solar.

Pero no solamente es la exploración, sino es el soporte de la vida en medios ambientes completamente diferentes al de la tierra, y donde esos advenimientos tecnológicos se van a ir incorporando y nos vamos a volver dependientes de quie- 
nes han descubierto esas nuevas innovaciones tecnológicas allá en el espacio, lo más cercano es la estación espacial internacional donde se han hecho muchos experimentos, hay 6 tripulantes y no se imaginan ustedes las toneladas de alimentos que llegan a ella para satisfacer las necesidades de esos 6 tripulantes ahí y la cantidad de experimentos y observaciones espaciales que hay y hacia el año 2025 aproximadamente se tendrá una estación espacial, ya en la Luna y de ahí exploración hacia otros planetas.

De repente uno está dedicado a cuestiones sociales más de relevancia aquí, de la alimentación diaria, como esto que ya hemos platicado, de los lácteos o de algunos granos como el amaranto, o de algunas otras cuestiones más en la solución de problemas sociales inmediatos y de las mayorías, pero hay cuestiones tecnológicas más allá, que hay inversión en ciencia y tecnología, bueno pues todos nos quejamos de que la ciencia y la tecnología tienen escasos recursos, por una parte si hay escasos recursos.

Ojalá y tuviéramos una especie de Plan Marshall como el que se tuvo en la Segunda Guerra Mundial para tener un incremento de recursos en investigación y desarrollo tecnológico en esta convergencia de saberes, pero no solamente es eso, sino planes prospectivos que nos permitan hacia el año 2050, 208003000 tener alternativas tecnológicas de desarrollo en núcleos importantes en la globalización, el dinero sí es importante, sí se requiere, siempre hay muchas necesidades, una de las cuestiones que nosotros tenemos en el país y que no se ha cubierto totalmente es el bono demográfico, o sea tenemos unos 7 millones y medio de jóvenes entre 19 y 23 años donde algunos tienen calificativos especiales para ellos, pero no están en las universidades, no están estudiando y sí cumplieron su ciclo medio y requieren algunos de ellos la posibilidad y la alternativa de una educación mejor a la que han tenido y suponiendo que de esos 7 millones y medio tuviéramos un $25 \%$ de capacidad para educarlos y tener nuevas alternativas me parece que sería algo bastante positivo.

En la cuestión de dedicación me parece que tenemos como el edificio nuevo que acabamos de construir, aquí en la Universidad, es un Centro de Innovación y Centro de Ingeniería Avanzada, en donde lo que se pretende realmente es hacer núcleos de desarrollo tecnológicos importantes, no solamente teóricos, no solamente prácticos, sino de vinculación con algunas de las empresas. Quienes hacen la innovación tecnológica no son las universidades, ni aquí ni en ninguna parte del mundo, quienes hacen la innovación tecnológica y resuelven los problemas son las propias empresas, son los grupos de empresas, pero si hay una parte importante de las universidades que no están alejadas realmente o no debieran estar 
alejadas de un contexto social y de otras empresas de las cuales pueden colaborar para resolver problemas.

Entonces a mi me parece que si hay que trabajar mucho en la formación de los egresados y en solución de problemas que realmente nos permitan una base en estos porcentajes que realmente son muy bajos con relación a la vinculación de las universidades, y hablo de todas las universidades. En el caso de la UNAM, debemos de tener por ingresos con vinculación alrededor de unos 1,600 millones de pesos, que es una buena cantidad de dinero, en el caso de Ciencias de la Tierra se va a firmar ahorita un convenio de 12 millones de pesos mexicanos, o sea 1 millón de dólares y sí se tienen proyectos de vinculación importantes con Petróleos Mexicanos, fundamentalmente con empresas que hacen algunos desarrollos de tipo impacto social como la Comisión Federal de Electricidad, la Comisión Nacional del Agua, Petróleos Mexicanos y que realmente están dando buenos resultados en términos de esta vinculación.

¿Dónde está ubicada la prospectiva aquí en Ingeniería?, en alguno de los desarrollos de los proyectos, pues tiene que ver con una visión de corto, mediano y largo plazo de los planteamientos que están haciendo, no es la solución a un problema inmediato o urgente, sino la solución de problemas que permitan a lo largo del tiempo tener mejores alternativas de desarrollo tecnológico para los proyectos que se tienen, y aparece una parte de entrada, en la parte izquierda y una parte de salida ya.

Pero ¿cómo estamos en nuestra formación de conocimientos, en la formación de los equipos, en la información que se está manejando?, algo de lo que hemos insistido es que tenemos que abrir las alternativas tecnológicas para la información, ¿qué se ha hecho en otros países? ¿Qué patentes se tienen? ¿Qué cuestiones de innovación tecnológica se han dado en términos mucho más amplios que el entorno donde nos encontramos?, esto cuesta mucho trabajo porque tiene que ver con la cuestión cultural, o sea nuestro entorno en realidad es reducido y eso hablaba de que somos algo así como personas extrañas y raros quienes nos dedicamos a la prospectiva, pero no solamente es esto, sino a abrir las ventanas y alternativas tecnológicas más allá de lo que nosotros tenemos como una información local y nos cuesta mucho trabajo porque mucha de esta información está en otros idiomas.

Pero tenemos que explorar y tenemos que tener esas alternativas de información para poder plantear primero como decían ayer, una de las partes importantes de la solución de un problema en un 50\%, decía Julio Millán, es entender el problema para darle solución.

Pero la otra parte es qué información tengo para darle solución o soluciones a los problemas, a 3 años, a 5 años, a 10 años, a 25 años, un mapa de ruta, nos 
indica así como hemos estado a lo largo del tiempo y hacia dónde podrían ir los vehículos de transporte que a veces ni nos imaginamos porque hoy lo prendemos y nos trasladamos en él, cuando falla, es cuando hay problemas. Quizá una de las partes más importantes, la trascendencia de las aportaciones de los trabajos que están realizando los alumnos, es decir, van más allá de la solución de un problema típico, y a mí me parece que sí es importante, yo les digo que tienen que aportar una solución de cambio mundial en las aportaciones que tienen que hacer y de repente se mueven, porque no es sencillo, no es sencillo tener aportaciones que van más allá de un entorno local, pero me parece que si esto lo logramos a lo largo del tiempo, a mediano y a largo plazo, tendríamos algo así como una incubadora de cerebros.

Esto que está aquí es la convergencia de saberes que para los siguientes años, 2030 aproximadamente, 2035, ya vamos a tener alternativas tecnológicas semejantes a las funcionalidades del ser humano, lo que le llaman singularidad, es decir va a haber procesos equivalentes a la inteligencia humana pero hechos a través de la electrónica, de la cuestión de una serie de secuencias de instrucciones de software, inteligencia artificial e inteligencia humana van a ser comparables. ¿Cuál va a ser la diferencia entre la inteligencia humana y la inteligencia de las máquinas? Bueno, es un enfrentamiento que va haber en los siguientes años y que tiene que ver con un ser humano integral, un ser humano sensible, social, de cambio, de aportación, y que realmente las universidades tendríamos que estar preparados para éstos cambios tecnológicos que vienen en los siguientes años, aquí en el caso de la Facultad de Ingeniería nos van a platicar sobre una nueva carrera, la Ingeniería en Sistemas Biomédicos que tiene que ver con esta convergencia de saberes y la aportación de la ingeniería en la parte de instrumentación y en la parte tecnológica hacia otras partes de las ciencias aplicadas.

Yo les digo a los alumnos aquí en la Facultad de Ingeniería es que los cerebros de los japoneses, los cerebros de los alemanes, los cerebros de los franceses, los cerebros de los mexicanos, de los brasileños, de los colombianos tienen en promedio la misma cantidad de células nerviosas, de neuronas o sea 10 elevado a la 11, un 1 con 11 ceros adelante, eso es la concepción de los hemisferios, pero uno de los detalles que a veces no tenemos nosotros, es como combinar el oriente con el occidente, o sea los hemisferios, el hemisferio izquierdo con el derecho, o el pensamiento oriental con el occidental o más allá, cómo están las conectividades de las neuronas que nos permiten soluciones alternativas en estos hemisferios como el lado izquierdo que es la parte lógica, matemática y el derecho que es la parte emocional, y emotiva, conjugarlos y dar nuevas propuestas y alternativas. 
Bueno estas convergencias de saberes tienen que ver con muchos de estos aspectos que todavía no hemos tocado con suficiente profundidad y cambio cultural realmente a los niveles que pueden realmente ser permeables a una sociedad mucho más simple que quienes están estudiando en las universidades.

Bien, algo de lo que hemos trabajado aquí, y con gran intensidad en la Facultad de Ingeniería es la educación a distancia, hay ya algunas instituciones que también han tenido prestigio en América Latina y son instituciones privadas como el Instituto Tecnológico de Estudios Superiores de Monterrey, pero la UNAM ha estado trabajando mucho en educación a distancia, y una de las experiencias que tuvimos, ya en el 2006, aprobado por el Consejo Universitario es una especialización en la parte de instrumentación y control en donde tuvimos algunos alumnos, o sea ya titulados en diferentes carreras que trabajaban fundamentalmente en Petróleos Mexicanos y ésta estructura de la especialización fue muy interesante porque utilizamos varias plataformas en donde no solamente era la interactividad que normalmente se hace a través de los celulares, mando un mensaje, recibo un mensaje, me rio o me pongo serio, me pongo a llorar, o bueno, hay expresiones que se dan siempre a través de esto.

Más allá de eso, fue una plataforma interactiva en donde podíamos ver a quiénes estaban enlazados, que esos ingenieros enlazados a través del sistema podían modificar programas de computación, podían preguntar, podían aportar y era una comunidad diferente de alternativas distintas de formación educativa más allá de la parte presencial que hemos manejado a lo largo del tiempo y nos pareció que los estudios de caso fundamentalmente que trabajamos con Petróleos Mexicanos, con expertos en campo, realmente dieron muy buenos resultados y felicitaciones realmente en la formación de quienes estaban en la parte de procesos de producción de la parte de explotación de hidrocarburos en el país.

Siemens, se estaba interesando y finalmente no se dio esto, pero esta cuestión asociada a las plataformas educativas y a un nuevo pensamiento que tiene mucho que ver con estas concepciones que también tenemos mentalmente, cómo se recibe la información, cómo se procesa la información, cómo se dan las comunicaciones de la información en el cerebro que realmente nos permiten dar soluciones alternativas a los problemas a través de esta formación y la otra parte que fue muy importante también fue los procesos de evaluación y finalmente los procesos de reorientación para ir mejorando a lo largo del tiempo, entonces la educación a distancia es una parte que realmente ha sido tocada de alguna manera de forma muy importante aquí en la Facultad de Ingeniería y desde luego tenemos especializaciones en distintos campos, uno de ellos es ahorro de energía y que también 
está en boga en todo el mundo y que nos ha permitido tener alumnos de distintas empresas y de la Comisión Federal de Electricidad en el caso del país.

Algunos de los que hacen planificación a corto, mediano y largo plazo, no se dan cuenta de que en realidad no hay $100 \%$ de eficiencia en ningún proceso, es decir, no toda la energía que uno pretende que realmente de los resultados es así, al 100\%, entonces siempre es menor al 100\%, y en ese porcentaje menor al 100\% hay que considerar realmente los alcances de lo que uno pretende, entonces la segunda ley de la termodinámica, lo que indica es que la energía no me va a dar los resultados del trabajo que yo espero, sino resultados parcialmente relacionados con un porcentaje menor al 100\%, y esto tiene que ver con el diseño de futuros, muchas alternativas de futuros.

Hacia qué futuro realmente estoy enfocando mis planes de estudio o hacia qué futuro estoy enfocando la solución de los problemas, esta cuestión de los escenarios, los escenarios son alternativas que se dan a largo plazo, pero hay otras técnicas, hay más de 200 técnicas que se pueden dar a corto plazo, ya en algunos minutos más nos van a platicar de alguna alternativa de aplicación, fundamentalmente del FODA, Fortalezas, Oportunidades, Debilidades y Amenazas, aplicado a un plan de ingeniería industrial, pero en el fondo de todo esto, no es la aplicación de una técnica, y ayer algo de esto se decía.

Yo lo que he hecho es la aplicación de técnicas, hablo en plural y la correlación de estas para después hacer propuestas, no tomar una de ellas y basarse en ella para tomar decisiones, sino varias de ellas para que sobre esta base se puedan tomar alternativas, y hacia dónde vamos. Ayer también se decía y lo retomo, es decir, si uno mismo no tiene metas a mediano y a largo plazo, cómo pretende realmente tener influencia en quienes están formándose en prospectiva para mediano y a largo plazo, entonces, gran parte de esto viene desde acá adentro, pero tiene que ver con un contexto en donde tenemos influencia y bueno pues el futuro deseable aparece por ahí.

Por ejemplo, hemos trabajado una hoja de ruta o mapa de ruta como le llaman y tiene que ver esto con una estructura que está basada en el análisis causal por capas de Sohail Inayatullah, que seguramente ustedes ya lo conocen, él está trabajando en una Universidad australiana, pero la parte histórica fundamental y sobre todo las partes importantes sobresalientes de la historia, hay que tomarlas en consideración para hacer un plan estratégico y prospectivo, el estado actual pero no en un contexto local sino en un contexto mucho más amplio, también hay que ser considerado, la cuestión social y cultural de donde estamos trabajando también, es importantísima y la otra es hacia dónde vamos con las alternativas que podemos tener de futuros. 
No solamente una propuesta, sino alternativas de propuestas que nos permitan lograr esto, bueno una parte del futuro alternativo de transporte tiene que ver con rutas aéreas, o sea con vehículos que pueden ser autónomos, me refiero manejados a través de redes, no necesariamente de un conductor en donde podamos tener un punto de inicio y un punto final y automáticamente el transporte nos lleve del punto A al punto B, pero también la otra alternativa que hay es cómo tecnológicamente vamos a desarrollar esto.

En Estados Unidos de Norteamérica en alguna información que estuve viendo, ya hay vehículos que pueden suspenderse y moverse y vehículos donde puedan ser 4, 6, 8 personas, están trabajando en la NASA en rutas aéreas, en ciudades, o sea no rutas terrestres, no neumáticos, no el carro normal que nosotros tenemos, sino ya están teniendo rutas aéreas experimentales, cómo estos vehículos van a tener estabilidad, cómo estos vehículos van a tener una determinada altitud determinada, bueno pues a lo mejor tecnológicamente al rato nos llega a México, les llega a Colombia y a Brasil, los desarrollos tecnológicos y las patentes que se desarrollan en estos países, entonces, una llamada de atención es para dónde va la tecnología y en qué campos y lo mismo sucede en organismos genéticamente modificados, en clonación o en otros aspectos de tipo alimenticio.

Un tema muy importante es saber en dónde están los jugadores, quiénes son los jugadores, de alto nivel, estamos hablando de las universidades, de los docentes, de los investigadores, de los técnicos académicos, de los especialistas, dónde empiezan y hacia dónde van, una de la partes importantes que en el mundo se dan son las publicaciones, o sea yo público y con esto tengo un status quo importante, y los procesos de evaluación realmente son benéficos para mí, pero el beneficio social hasta dónde llega en el desarrollo de una innovación tecnológica, por ejemplo, una prótesis, nosotros tenemos un grupo trabajando de forma importante en prótesis, ayer me decían acerca de una silla que diseñaron para personas que no pueden tener una locomoción normal, entonces hacia dónde vamos con todos estos jugadores, realmente para los siguientes 20, 30 o 40 años en términos de la formación de núcleos y de equipos de trabajo que den prestigio realmente a la institución o al desarrollo tecnológico en donde estamos y bueno finalmente algunas conclusiones.

Los indicadores de desempeño pues son como tales, hay que tomarlos, analizarlos y decir bueno positivo o negativo, voy bien, voy mal, pero son indicadores al fin, son información que me va a permitir a mi después tomar decisiones, después viene ahí que el futuro deseable, alineado y balanceado porque si hay que alinearlo y balancearlo, ¿para dónde vamos?, esta cuestión del señor Carroll que 
escribió dos libros, uno es Alicia en el país de las Maravillas en alguna parte donde Alicia llega y está el gato y dice bueno cuál camino tomaré, pues si no sabes a dónde vas, cualquier camino es bueno no, entonces sí tenemos que tener metas de alternativas, personales, de equipos de trabajo, de proyectos y más allá de un impacto importante sobre todo en las universidades dentro del país, necesitamos aumentar la educación, bueno pues eso en todos los países, pero no solamente aumentar en la educación, nosotros en la universidad cumplimos con las funciones que tenemos, las funciones sustantivas, pero no solamente en la formación de las universidades, sino qué hay más allá de eso.

¿En realidad nuestros egresados tienen un empleo digno, bien pagado, adecuado, realmente a los estudios que han tenido?, desde la primaria, la secundaria, la preparatoria, la educación profesional y el posgrado, lo que se esperaría en los siguientes años es que todos los egresados tuvieran oportunidades de desarrollo, particularmente en el campo en donde han estudiado o al menos oportunidades de desarrollo y bien pagados de acuerdo a su formación.

Algo de lo que también pretenderíamos y la Dra. Guillermina Baena que está presente con nosotros, nos lo comentó en algún momento, es el planteamiento y además la posibilidad de que pudiesen tener esa decisión de tener en las universidades no solamente un centro de desarrollo de prospectivistas sino de partes importantes de desarrollo de todo lo que es la universidad para 30, 40, 50 ó 60 años pero con influencia en el hacer.

Ayer decía Julio Millán, porque me parecieron algunas cosas importantes de lo que él decía, que no solamente importaba la parte teórica de los proyectos prospectivistas o de los proyectos que ellos hacen, (hablaba del estado de Veracruz), sino que realmente se llevaran a efecto y a mí me parece que en el caso de las universidades debería ser no solamente un núcleo de estudios prospectivistas, sino además que realmente hubiera un seguimiento y se llevaran a efectos estos planes, hasta ahorita en este país, no conozco un plan a 50 años, pero sí conozco de empresas como Sony y icómo le hacen?, de repente uno dice bueno, pues es que tiene que haber alguna información de donde ellos vayan tomando algunas cuestiones como esto de los ciclos cortos, ciclos largos en las investigaciones, de la cuestión de cómo ellos van a ir trabajando a lo largo del tiempo, yo creo que esto si se puede hacer.

Otra de las cuestiones es que debemos de trabajar sobre nuevos planes de estudio, entrando a dos bancos de información chinos tienen unas carreras rarísimas ya ahorita, raras, para lo que es el contexto de lo que manejamos tradicionalmente nosotros, pero necesitamos trabajar en cambios que nos permitan alternativas no- 
vedosas y distintas y desde luego, como alguien dijo bueno y si tú puedes plantear un plan de estudios novedoso, creativo, ingenioso y diferente, ¿quién va a contratar al egresado? bueno, hay cosas que habría que empatar ahí.

Y finalmente es esta cuestión de lo que nos hace diferentes con los chinos o con los japoneses o con los de Corea del Sur. Corea del Sur en 1964 quiero decirles que estaba en una calidad de vida menor a la mexicana, en 1964 cuando en el caso de México se inició un programa importante que es el programa de braceros y después el programa de la maquila, bueno, ellos han superado realmente el desarrollo tecnológico de tal manera que es un país en donde la calidad de vida es totalmente diferente de 1964 a 2014 y en el caso de México no hemos avanzado de la misma forma.

Una de las cuestiones platicando con alguno de los doctores que ha estado por allá en Corea del Sur me decía, es que las exigencias en las universidades deben ser mucho mayores de las que han sido, particularmente en el caso de la UNAM, en formación y realmente en la cuestión propia de la exigencia de que quienes se titulen realmente tengan aportaciones importantes y desde luego, no sé el cerebro, o sea no es nuestro cerebro con 10 a las 11 neuronas, sino cómo están las conectividades, cómo está la cuestión, está de ir más allá, lo que decían, de la caja, ir más allá de lo que es el contexto del paradigma que hemos manejado naturalmente y bueno, pues es una llamada de atención.

Nosotros estamos trabajando realmente y nos está dando buenos resultados las cuestiones de propiciar que los alumnos tengan una visión diferente a la que tenían en el pasado, en el entorno de solución de problemas tecnológicos y bueno yo lo dejaría de esta manera para que realmente hubiera preguntas, comentarios y aportaciones pero fundamentalmente el futuro, el futuro no es algo que esté determinado y en este sentido pues podemos construirlo, podemos tener una meta, podemos tener planes, estrategias y acciones y es ahí donde necesitamos ir todos nosotros, en el presente para poder desde este momento crear, formar y tener resultados en un futuro deseable. Muchas gracias.

\section{PREguntas y RESPUESTAS}

-Ingeniero, ¿me puede ayudar por favor en repetir los datos de estudiantes, docentes, catedráticos de la Facultad de Ingeniería?

$\mathrm{R}=$ sí, lo que tenemos es 256 profesores de tiempo completo aquí en la facultad, en 12 carreras que impartimos, son 12 carreras las que tenemos aquí en la 
Facultad de Ingeniería y para el año que entra si el consejo académico y el Consejo Universitario lo aprueba tendremos una décima tercera carrera. Tenemos 12,500 alumnos de licenciatura y 1,500 alumnos de posgrado, eso es lo que se maneja aquí en la facultad y en la lámina que está atrás nos aparece un contexto mucho más amplio. Tenemos aproximadamente un poquito más de 100 carreras, $110 \mathrm{ca}-$ rreras de licenciatura en toda la UNAM en todas las disciplinas y un valor agregado de información que quizás valga la pena es que de los posgrados, los posgrados nacionales el $50 \%$ está en instituciones públicas y el otro $50 \%$ en instituciones privadas, eso es interesante también, más enfocados hacia la parte de administración que es ya la parte de tecnología. Bien, ¿algún otro comentario o pregunta?

— ¿Qué carreras tienen en formación a distancia?

$\mathrm{R}=$ En licenciatura en el caso de la Facultad de Ingeniería no tenemos licenciaturas en educación a distancia, solamente tenemos especializaciones, ahorita tenemos el de Ahorro de Energía y tenemos la que ya les comentaba, de instrumentación y control en dos grandes enfoques, uno hacia la parte de energía, fundamentalmente a través de redes, de redes desde la generación hasta la distribución y en la parte de energía fundamentalmente hacia Petróleos Mexicanos que es la parte de extracción y distribución de hidrocarburos, pero eso es lo que hemos manejado hasta ahorita, yo estoy convencido de que una de las partes importantes para los siguientes años será la educación a distancia e implica un esfuerzo mucho mayor a quienes están en este contexto de formación, no es lo mismo venir, asistir y compartir en un aula como esta, o en un auditorio como éste que estar a distancia y tener que prepararse de una manera totalmente distinta, pero el avance tecnológico nos permite realmente tener una interacción e interactividad con quienes están formándose de tal manera que las equivalencias se están dando ya en las licenciaturas, que no es el caso de la Ingeniería, pero en otras licenciaturas, como en la parte de filosofía que ya se está manejando, en la parte de la contaduría ya se está manejando y que más tarde bueno vamos a estar con el maestro José Silvestre que él ya ha tenido experiencia porque fue asesor de la Coordinación de la Universidad Abierta y de Educación a Distancia. Bien, algún otro comentario o pregunta.

-En este proceso de alta tecnología, relacionado con la exploración y con la investigación del espacio y... soporte entre otros, logístico, alimentos, ¿cuál es su opinión sobre transgénicos?

$\mathrm{R}=$ Bueno, yo propongo, hay varias cuestiones que se van a dar en los siguientes años no, a mí me parece que se puede seguir trabajando mucho más todavía en alimentos naturales, o sea de origen tradicional no, la producción no ha sido explotada con la eficiencia suficiente hasta ahorita no, pero la cuestión de los 
transgénicos es algo que ha surgido en los países que llamamos desarrollados, o sea de alta tecnología y que realmente lo que están haciendo es produciendo y exportándolo.

El caso de los cereales, el caso de los cereales es un ejemplo típico de esto, me parece que mientras no logren ellos tener alternativas tecnológicas, en donde no haya efectos secundarios, es decir, que aseguren que no va a ver problemas orgánicos en el ser humano pues eso se puede seguir trabajando, pero yo iría más a lo natural que a los medios de los transgénicos u organismos genéticamente modificados, o sea más a lo natural y creo que se puede explotar mucho más, voy a poner un ejemplo no, en Estados Unidos de Norteamérica que es de los países que más produce alimentos se tienen aproximadamente por hectárea, en el caso del maíz 16 toneladas por hectárea, y en el caso de México en las mejores tierras no llegamos a 8 toneladas por hectárea, entonces se puede seguir trabajando realmente en la producción de alimentos de una manera más amplia no, para el año 2050 o 2070 uno de los países que tiene oportunidades de desarrollo en alimentos es Brasil, es un país con una oportunidad para producción de alimentos mucho más grande que los Estados Unidos de Norteamérica por toda la región que tiene, pero yo me iría a lo natural más que a lo transgénico o a los organismos genéticamente modificados que se van a seguir trabajando y que bueno ya hay patentes relacionados con esto en Estados Unidos de Norteamérica que eso es interesante también.

— ¿Yo quisiera saber si la Facultad de Ingeniería ha tenido algún reconocimiento a nivel nacional o internacional con respecto a todo su desarrollo en innovaciones tecnológicas que hay de toda la UNAM, le parecería que deberían otorgárselo?

Bueno, una buena parte la voy a contestar yo, porque acaba de haber un evento del Banco Bilbao Vizcaya de un premio nacional pero es un Banco que tiene su sede en otro país, en donde nuestros egresados ganaron un premio y tenemos algunos otros, pues también asociados. Si quiero decirle que en el periodo anterior con el rector De la Fuente en la Cámara de Diputados se inscribió en letras de oro la UNAM, entonces sí hay un reconocimiento importante, la otra es el Príncipe de Asturias que fue galardonada la Universidad con este Rector actual, en España.

O sea, sí hay premios internacionales de la UNAM, hay destacados investigadores que han recibido también premios importantes, a lo que yo voy en este contexto que hay, es que sí tenemos cerebros, sí tenemos investigadores, sí tenemos un núcleo posible, potencial de mayores oportunidades y resultados, lo que me parece es que no han sido suficientemente grandes con todo este esfuerzo para lograr un cambio social permanente, por ejemplo, que el advenimiento de todos 
estos avances tecnológicos pudiese tener permeabilidad social en el país y que esto ayudara junto con políticas adecuadas al desarrollo de un Producto Interno Bruto de alrededor del 6\% para en 15 años duplicáramos la economía nacional, o sea, sí hay y realmente estamos satisfechos con la labor que hace la Universidad, es la más importante de este país y de hecho de muchos países de América Latina.

Estos cambios de planes de estudio, nos van a platicar un poquito de Ingeniería Industrial pero en Mecatrónica, en la parte mecánica, en la parte de material eléctrico electrónico, en la parte de computación, en la parte de telecomunicaciones y todas estas carreras sirven como un indicador importante en términos de por dónde se están trabajando estas cuestiones de formación de los recursos humanos para los siguientes años.

P: ¿Cómo ha sido la experiencia de la UNAM, respecto a nivel nacional o nivel estado, para que la gente comience a pensar en prospectiva y a pensar en construir en futuros, porque para nuestro caso ha sido bastante difícil en nuestro país especialmente en nuestra ciudad de Cali y cambiar esa mentalidad de empezar a construir futuro en una fase, me gustaría saber cómo ha sido la experiencia a nivel de su facultad para cambiar esa mentalidad a nivel es todo, o sea que el estado invierta en construir...?

$\mathrm{R}=\mathrm{Si}$, bueno, ya hay un relativo convencimiento de los gobernantes de incrementar el porcentaje dedicado a la investigación y desarrollo en el país, ahorita está al 0.5\% del PIB y se espera en este sexenio que estamos en el segundo año de gobierno llegar al 1.0\% del PIB, que son esfuerzos yo diría importantes, pero cuando comparamos esto con los porcentajes de igual manera del $0.5 \%$ del PIB de los EU de Norteamérica pues es una cantidad realmente diferente.

Sin embargo, también, la otra parte sería la iniciativa privada, o sea la inversión de las empresas privadas, sobre todo de las grandes empresas en investigación y desarrollo, de cada 4 empresas, vamos a decir una de ellas hace investigación y desarrollo realmente. Entonces sí se necesita crear una base de desarrollo tecnológico de iniciativa privada más importante de lo que ha habido en el pasado, con financiamiento propio de las empresas, con incentivos fiscales y con políticas adecuadas que permitan un desarrollo, sí se han hecho esfuerzos importantes, sí hay un convencimiento al menos del gobierno de decir vamos a incrementar la inversión en investigación y desarrollo y yo digo que esto tendría que tener un mejor futuro. Ahora, relacionado con los prospectivistas, bueno uno de los grandes problemas que tenemos nosotros es la credibilidad, el convencimiento y la incorporación de las ideas en los nuevos planes y programas y esto no es sencillo, creo que el esfuerzo que tenemos enfrente es mayor, y la capacidad para resolverlo está abierta, yo lo dejaría de esa manera. 
- ¿Cómo es el apoyo que usted le da a los proyectos de afuera?

$\mathrm{R}=$ Bueno, lo voy a contestar y usted me dice si es por ahí la idea, lo que tenemos nosotros es encargados en cada una de las divisiones de la cuestión de convenios relacionados entre la Facultad de Ingeniería y las empresas, entonces, lo primero que se hace es que la empresa plantea los problemas que tiene y el grupo de académicos se reúne para lograr tener un entendimiento de cuál es la problemática a resolver, después de eso, se valora, sobre todo los tiempos, la iniciativa privada, una de las cuestiones que tiene es que quiere resolver el problema para ayer, ya ni siquiera para este momento o sea ya lo tengo que haber resuelto y es una de las limitaciones que a veces hay porque los grupos de trabajo no son tan especializados para resolver lo que llaman el traje a la medida o la solución del problema planteado.

Pero una vez que esta parte traslapa entre el empresario y la UNAM se hace un convenio y esta es una cuestión también de tiempo, a veces se dice que los tiempos de los convenios no son suficientemente cortos como para hacer eficiente el proceso pero se hace esto y se puede ir trabajando, se evalúan los costos, se propone y se lleva a efecto un cronograma, o sea un tiempo para la solución del problema y sobre esa base, pues, se cumple con lo establecido en el propio convenio. Bueno, hace rato no comenté, pero una de las cuestiones interesantes de las patentes, o sea no es la solicitud de la patente y la concesión de la patente, sino la explotación propia de la patente porque hay quienes patentan y bueno, parece que queda nada más como algo, digamos halagador para quienes la realizan.

Una vez que está la patente, pues la cuestión sería quiénes están interesados en explotarla sobre todo en algunos campos, por ejemplo ahorita se diseñó una silla, una silla que tiene características especiales asociadas a la cuestión propia de personas que no pueden tener una forma normal de locomoción y en ese sentido pues la cuestión es está la solicitud de patente en transición, una vez que se da esta patente, entonces ya queda abierto a que quien quiera explotarla, pues pueda hacerlo, de lo que yo sé es que en la Universidad, hay una parte de la administración, pero no son, vamos no es una cuestión propia con la iniciativa privada de un cobro alto de la explotación de las patentes, si no más un beneficio social de esta patente para su uso.

¿Qué quiere decir? que si hay a veces porcentajes del 1 o 2\% del producto ya en venta que permiten un ingreso a la universidad pero en general es un beneficio social que se da, en prótesis, se están trabajando algunas cuestiones no solamente de materiales sino asociadas a cuestiones de dedo de manos, de parte de brazos, de parte de las rótulas y que ahorita están en transición las patentes pero una vez 
terminadas son realmente más un beneficio social que una cuestión de ingreso mayor para la Universidad, pero esto sienta las bases de un cambio importante porque a veces las de la iniciativa privada no recurren a las universidades por estos tiempos diferenciados que hay entre la capacidad de las universidades para resolver un problema y la necesidad de ellos, de los empresarios, de resolverlos para ayer.

Está con nosotros el Doctor García Ugalde, él es el Jefe de la división de Ingeniería Eléctrica, es el jefe de mi jefe. Lo invité con mucho gusto, además porque él perteneció al Sistema Nacional de Investigadores, pero bueno ahora tiene un cargo y pues tiene que dedicarle a otras cuestiones que no son exactamente la investigación y desarrollo en su tiempo. Él coordina a través de 3 jefes de departamento 3 carreras dentro de la Facultad de Ingeniería, de las 12 carreras y le pedí que nos acompañara para platicarnos un poco del escenario hacia el 2020, de estas ideas de la parte eléctrico-electrónica, de telecomunicaciones y de computación, en esta visión que se tiene de cambio hacia la formación de quienes están en las licenciaturas y bueno, quiero decirles que él hizo su doctorado en Francia

\section{Habla el Doctor García Ugalde:}

Yo llego un poquito a la carrera porque vengo ahorita de otro evento, no me había quedado claro, cuando platiqué con Paco sobre esta reunión y en consecuencia no traigo preparado ningún material, les voy a comentar con base a lo que estuve escuchando ahorita del contexto de la presentación de Francisco y de las preguntas que se estuvieron presentando, algunos datos, más que datos, algunos comentarios que podrían enriquecer y quizá transmitirles un poquito más de información.

Como mencionó Francisco, yo soy el jefe de la División de Ingeniería Eléctrica, ahí tenemos 3 carreras principalmente la parte de Computación, de Telecomunicaciones y Eléctrica Electrónica, y en esas partes nos estamos yendo mucho a la parte de redes, por ejemplo, cuestiones de seguridad, cuestiones de procesamiento de voz, procesamiento de imágenes, cuestiones de circuitos integrados utilizando redes, en cuestiones de transmisión vía satélite, redes de radiofrecuencia, cuestiones de seguridad como control de errores, cosas de criptografía, cuestiones de comunicaciones inalámbricas, eso es algo que también forma parte de los planes de estudio y bueno creo que es todo.

Aquí se habla de la prospectiva incluida dentro de la revisión de planes de estudio, quizás no explícitamente como ustedes la manejan pero sí tenemos que hacer un estudio previo de cómo anda la cuestión. 
La prospectiva está incluida en la revisión de planes y programas de estudio porque tenemos que ver cómo anda nuestra universidad respecto a las universidades nacionales, cómo anda nuestra Facultad respecto a las escuelas y a universidades internacionales también para poder proponer una revisión de planes y programas de estudio, entonces no es tan explícito como lo mencionan ustedes, pero implícitamente sí va incluida la prospectiva para poder hacer una buena propuesta de planes y programas de estudio.

Respecto a los premios que usted preguntaba, hay muchos reconocimientos a la UNAM y muchas veces se pierden porque la población es tan grande que también es difícil mantener un compendio de todo lo que se está logrando, uno de los últimos que le podría yo mencionar y que tiene que ver también con los estudiantes, no sé si se enteraron, pero es algo que sale en las noticias, recientemente hubo una reunión en Francia, en Versalles, para poder desarrollar bajo ciertas condiciones, tecnología, mostrar cómo se puede utilizar la tecnología para construir vivienda sustentable, la UNAM participó con un grupo de estudiantes, tanto de la Facultad de Ingeniería como de Arquitectura, y se lograron muy buenos resultados.

A nivel global, la UNAM quedó en el $13^{\circ}$ lugar, pero dentro de ese grupo hubo categorías un poco especificas, por ejemplo, en Ingeniería en Construcción quedamos en primer lugar, en cuestiones de estabilidad en cuanto al bajo consumo de la casa, porque se tuvo que construir una pequeña casa habitable, ahí quedamos en tercer lugar, ahorita los chicos, otro grupo de estudiantes anduvo en Brasil, en el RoboCop, ahí son estudiantes tanto a nivel licenciatura como a nivel preparatoria, los de preparatoria en México, son la parte previa a la licenciatura, en esos grupos de estudiantes se involucró también a estudiantes de nivel preparatoria y también obtuvieron buenos resultados.

Ahora, ¿cómo nos miden también a nosotros como académicos? cómo me puedes decir si estás bien o si lo que estás haciendo tiene repercusión o no, nos miden mucho por las publicaciones, eso hay que decirlo, nosotros como profesores, los investigadores tenemos que estar publicando constantemente en revistas, se mide el factor de impacto de las revistas en donde estamos publicando, se mide cuántas citas se han tenido de los trabajos publicados, etc.

Y podemos decir que dentro de la Facultad de Ingeniería se encuentra un profesor, porque también eso es difícil verdad, Dr. Leoni Freeman que es el que ha tenido a nivel UNAM, a nivel de toda la UNAM, es el que ha tenido más citas, en compendios de publicaciones bastante elevadas, mencionaba Francisco que tenemos el Sistema Nacional de Investigadores, es un sistema que nos clasifica en 4 niveles, lo que le llaman candidato que son los que empiezan, los jóvenes, 
y luego nivel 1, nivel 2, nivel 3, los que llegan a nivel 3 son los más altos, este profesor que yo les menciono es un Sistema Nacional de Investigadores nivel 3, dentro del área de Ingeniería Eléctrica tenemos otros dos profesores que son nivel 2, uno de ellos está en el área de Energía y el otro está en el área de Comunicaciones Ópticas, en total dentro de estas 3 carreras que yo les menciono, que es Computación, Eléctrica Electrónica, y Telecomunicaciones, tenemos un total de 25 profesores que forman parte del Sistema Nacional de Investigadores sobre un total de 85 , entonces ustedes pueden sacar de ahí un cierto porcentaje para ver un poco cómo anda la planta académica.

¿Cuáles son nuestras labores como profesores? obviamente impartir docencia de acuerdo con la categoría que tenemos como nombramiento en la UNAM, tenemos que impartir ya sea 2 cursos semestrales o 3 cursos semestrales, tenemos que dirigir tesis, tenemos que hacer publicaciones y tenemos que llevar a cabo administración también, entonces la verdad es que nos falta tiempo para hacer todo lo que tenemos que hacer y pues ni modo, hay que hacerlo, y en cuanto a la revisión de planes y programas de estudio es un proceso que nos llevó, todavía no acaba, pero ya estamos en el último paso, falta todavía una aprobación a nivel de los Consejos Académicos de Área, pero es un proceso que nos ha llevado 4 años.

En esos 4 años ¿qué hemos hecho? Hemos hecho primero la parte de prospectiva, es decir como andaba nuestro plan de estudio anterior con respecto a los planes de estudio del mundo y también del propio país y en qué áreas nos queríamos mover, la parte de computación, por ejemplo, nos fuimos hacia un núcleo, un núcleo que tiene que ver mucho con bases de datos, con cuestiones de hardware y con cuestiones de software y a partir de ese núcleo estamos sacando lo que le llamamos nosotros módulos terminales y esos módulos terminales van hacia las redes, hacia la seguridad, hacia las bases de datos, hacia el hardware, hacia el software, hacia la computación gráfica que ahora tiene mucho que ver con los videojuegos, la parte de electrónica, ahí nos estamos yendo hacia lo que les decía yo de mentes de circuitos, tenemos un laboratorio de mentes certificado donde podemos hacer diseño, podemos hacer validación y construcción de mentes, las mentes los estamos orientando hacia la industria automotriz por un lado y hacia la parte de Bioingeniería por el otro.

Tenemos la parte de control, la parte de control automático, la parte de sistemas eléctricos de potencia, o sea, todo lo que es transmisión de energía en altos voltajes, tenemos la parte de sistemas energéticos en donde entra, tenemos una parte de energía nuclear y tenemos una parte de fuentes alternas de energía como pueden ser energía solar, energía térmica, cogeneración, eólica y tenemos 
la parte de procesamiento de señales, donde está todo lo que es procesamiento de voz, procesamiento de imágenes, ya ven que actualmente todo lo que es multimedia tiene mucho que ver con codificación de voz, codificación de imágenes, codificación de video, bueno esa otra parte y la parte de telecomunicaciones es la parte comunicaciones vía satélite, comunicaciones inalámbricas, sistemas de radio frecuencia, seguridad, seguridad en las redes, de comunicaciones ópticas y la parte de ingeniería para sistemas espaciales.

La industria aeroespacial se está desarrollando mucho en México, hay ya en la zona de Querétaro, muchas industrias que se están implantando ahí para generar productos para la industria aeroespacial y también para la industria automotriz, toda la parte del Bajío, Aguascalientes, Guanajuato, Querétaro, es una zona que está tomando mucha fuerza en las partes para la industria automotriz.

Ayer tuvimos la presentación ante los padres de familia de los estudiantes de nuevo ingreso que van a entrar a nuestras 12 carreras de la Facultad de Ingeniería y uno de los papás preguntaba ¿qué es la Mecatrónica? porque una de las carreras que tiene la Facultad de Ingeniería es la Mecatrónica, la Mecatrónica es la carrera que ahorita a nivel UNAM es la que les pide el mayor número de puntos para poder acceder a ella, el número de plazas son pocas, son pocos los que logran entrar y está muy peleado el acceso y qué es la Mecatrónica, pues es la integración, son ingenieros que saben integrar cuestiones de electrónica, cuestiones de computación, cuestiones de control, cuestiones de automatización, etc., y las aplicaciones pueden ir hacia la industria automotriz, hacia esto que les decía yo de los premios de este concurso, en donde fue la vivienda sustentable. Muchas gracias. 


\section{PROSPECTIVA EN ADMINISTRACIÓN: SILVESTRE MÉNDEZ MORALES}

uenos días, pues vamos a empezar la plática, porque ya saben que los tiempos nos comen. En la invitación de la Doctora Baena, me dijo que preparara una plática sobre prospectiva en la administración, que es el tema, con base en el curso Profundización de la prospectiva: estudio de caso en México. Quiero comentarles que su coordinadora académica ya tiene la presentación para el que la quiera tener, para que no la copien, sería interesante hacer las preguntas al final, sería más enriquecedor y lo de la presentación es para compartirla con ustedes. Básicamente vamos a tocar dos puntos, me dieron muy poquito tiempo y los puntos que vamos a tocar el día de hoy son los antecedentes de la prospectiva en la administración y pues vemos al final las preguntas que ustedes deseen formular.

Vamos a empezar con los antecedentes, en primer lugar, la administración ya aparece en un diálogo de Platón, se habla de economía como administración de la casa, ahí está el término griego, la administración no es algo nuevo que haya surgido apenas, sino es una cosa que ya tiene mucho tiempo y que además teóricamente empieza, repito, ya en los diálogos de Platón, de aquí surge y se desarrolla, y la que tiene más proyección la economía como ciencia, no tanto la administración, sino la economía como ciencia, y esto es un problema que vamos a ver como falta de claridad de la administración.

Platón plantea que los hombres tienen que administrar la vida para vivir en comunidad, recuerden que el ideal importante de los griegos era la vida en comunidad, la vida en común, esto lo quiero resaltar mucho porque es una situación que hemos ido perdiendo a lo largo de los siglos.

Tal parece que lo más importante es la persona, el sujeto y que lo demás no importa, aquí se hablaba precisamente de los hombres que tienen que administrar, 
qué administran, pues administramos nuestra propia vida, pero esta vida siempre es una vida en comunidad, una vida en común con los otros, entonces pues lo que administramos también son cosas y acciones humanas para el bien común, esta es la idea original que insisto se ha ido perdiendo a lo largo del tiempo, es una idea Platónica, de los griegos, donde lo importante era el bien común, hoy parece que hablamos de cosas muy anticuadas si queremos hablar del bien común, ipor qué?, porque lo que nos interesa son nuestros bienes personales, subjetivos, mi casa, mi coche, mi familia, mí, mí, mí, entonces se ha ido perdiendo la cuestión del bien común, la administración es concentración de voluntades libres, antes de ser una disciplina social, la administración es una actitud, eso lo dice un filósofo que trabaja con nosotros aquí en la división de investigación, que se llama Juan Manuel Silva Camarena, ahí está su fotografía, concentración de voluntades libres, nosotros no podemos administrar en forma obligatoria a alguien que no quiera ser administrado, tiene que haber voluntad de esta administración porque si no, ya se perdió la esencia de lo que es administración.

Fíjense, hemos estado hablando de elementos fundamentales que hemos ido perdiendo a lo largo del tiempo, bien común, y ahora hablamos de libertad que es muy importante. Se administran por lo tanto seres humanos libres que pueden tomar decisiones, la actitud administrativa es una bella actitud de la armonía de las voluntades, vean qué bonito expresa este pensamiento, bella actitud de la armonía de las voluntades, esta es una situación que también hemos perdido, vean lo que está pasando a nivel de los países, de los partidos políticos, de las instituciones, no hay ésta bella actitud de la armonía de las voluntades, aquí las cosas son impuestas.

Los elementos fundamentales de la administración son planear, ejecutar, controlar, dirigir las actividades económicas para satisfacer las necesidades sociales, esto también es una cuestión fundamental y básica que quiero plantear, que todo lo que hace la administración es con el objetivo de administrar todo lo que realiza el hombre para satisfacer sus necesidades, pero tal parece que se nos ha olvidado que estas necesidades son necesidades sociales, necesidades de las personas viviendo en comunidad, no son necesidades individuales, personales, subjetivas; un ejemplo muy claro es esto del último mundial que nosotros vimos, el fenómeno parece ser que es generalizado en varias partes del mundo.

Cuando hay futbol, es la compra de televisores, todo mundo quería su televisión, de plasma, la más grandota, etc., y nos olvidamos de lo que son las necesidades sociales importantes básicas como sería la alimentación, el agua, la salud, la educación, etc.; por lo tanto, la administración es la responsable de canalizar el 
esfuerzo humano para la solución de los problemas económicos, recuerden que los problemas económicos fundamentales de toda sociedades son: qué producir, cómo producir, cuánto producir, para quién producir y dónde producir, entonces, si nosotros contribuimos a la solución de estos problemas, lo tenemos que hacer a través de la administración y parece ser que esto no ha sido la solución, todavía encontramos a nivel mundial problemas de alimentación, problemas de muchas cosas, no hemos podido resolver esto porque se ha encaminado a otra cosa.

Administración, en síntesis, es un conjunto sistematizado de teorías, conceptos, procedimientos para analizar y modificar el funcionamiento del sistema económico para alcanzar objetivos definidos, quiero hacer énfasis en esto, porque vamos a hablar de prospectiva ahora, en primer lugar, se trata de analizar el funcionamiento del sistema económico, recuerden que analizar significa descomponer un todo en sus partes, pero nos quedamos en el análisis o en la modificación. Carlos Marx decía que lo importante no es conocer el mundo sino lo importante es transformarlo y transformarlo en el sentido que les estoy diciendo, transformarlo para el bien común.

Vamos a hablar de la prospectiva, prospectiva en administración, aquí tienen ustedes a Rigoberta Menchú, ella dice, "este mundo no va a cambiar a menos que estemos dispuestos a cambiar nosotros mismos"; esta es la esencia fundamental de la prospectiva, nosotros en el Seminario de Prospectiva decimos: "nosotros no tratamos de hacer prospectiva, nosotros queremos ser prospectivos", es decir cambiar nosotros mismos para poder tratar de cambiar nuestra comunidad, nuestro lugar de trabajo, nuestro país y bueno pues si se puede, pues el mundo.

Se propone cambiar la administración para las próximas décadas con nuevos enfoques, a mí me parece que el enfoque de la administración no ha sido el correcto, de acuerdo con la idea inicial como cito, la administración como una idea Platónica del bien común, de voluntades libres, de armonizar todas estas situaciones como estamos comentando. Por lo tanto, más que hablar de cómo ha sido, requiere hacerse una propuesta: quiero que esto cambie, porque yo no estoy convencido de que esto ayude a mejorar las condiciones de vida de la gente.

La administración de las próximas décadas debe basarse en primer lugar en los derechos humanos, tal parece que nos olvidamos de los derechos humanos fundamentales en el bienestar humano, en el buen vivir y por supuesto en la búsqueda de la felicidad, no venimos a este mundo a ser infelices, esto también era el ideal griego, tratar de ser felices en la vida, no tenemos por qué complicarnos; pero para llegar a esto, bueno, pues cuál es el nivel de bienestar de la gente, cuál es el respeto de los derechos humanos, la humildad, la libertad, de lo que hablábamos 
hace un rato, por lo tanto la administración debe cambiar sus paradigmas y no basarse en forma exclusiva en la productividad y la competitividad, tal parece que son las palabras más sonadas, lo dicen los brillantes políticos, lo dicen los gobernantes de los países, lo dice todo el mundo, es que tenemos que ser más productivos, más rentables.

Y la productividad, el bienestar humano y la satisfacción parece ser que ya nos olvidamos de ello, entonces tal parece que vivimos para trabajar, no como decíamos antes, trabajar para vivir, como que nos hemos olvidado mucho de esto, y tal parece que los nuevos dioses que están alrededor del mercado que es el que regula todo, son la productividad y la competitividad.

La administración del futuro no debe hacerse en función del mercado, la eficiencia, la eficacia, la racionalidad; son las palabras que más se oyen en estas Facultades de Contaduría y Administración, eficacia, eficiencia, racionalidad, mercado. Yo creo que el enfoque tiene que cambiar, tiene que cambiar en términos de la función social que debe desempeñar la administración y no solamente pensar en el mercado. Si nosotros lo sintetizaremos mucho es pensar en la máxima ganancia para unos cuantos, para los que dirigen las empresas, por eso tiene que cambiar este paradigma.

La administración del futuro debe basarse en la cooperación y la solidaridad humana, son dos cosas esenciales que desde los griegos lo tenemos, eso de cuando nosotros hablamos de comunidad, ¿de qué estamos hablando? Estamos hablando de solidaridad humana, en la esperanza y la utopía, por supuesto que queremos mejorar las cosas, queremos cambiar para mejorar, la utopía como un ideal en la cual empezamos a trabajar desde ahorita para lograr eso que queremos, no como algo que no existe y qué bueno es un sueño guajiro, trabajamos para lograrlo, planteamos estrategias para ir funcionando en términos de ellos y lograr lo que queremos.

La nueva administración debe propiciar la toma de decisiones ciudadanas de trabajadores, obreros, empleados y campesinos, y esto es justamente lo que no sucede, no tomamos en cuenta a la gente, voy a dar un ejemplo relacionado en nuestro país, recientemente en esta semana, todavía se sabe discutiendo las leyes secundarias sobre la reforma energética, pues al pueblo, a la sociedad, a los científicos, a la gente que sabe y a los afectados no se les ha tomado en cuenta para nada, es la decisión que toman los políticos en las Cámaras de Diputados y Senadores y no todos, sino una fracción que está a favor de esta reforma energética sin consultar a nadie, a mí me parece que este tipo de acciones ya no deben hacerse, que cualquier decisión que afecte a la gente, se le debe tomar en cuenta, 
es decir, tiene que ser algo así como a lo que los teóricos llaman, administración participativa, todo mundo tiene que participar, pero no todo mundo tiene que participar nada más recibiendo órdenes, sino precisamente tomando parte de las decisiones fundamentales por una razón muy sencilla: porque les van a afectar.

Entonces es necesario tomar en cuenta a la gente, a los ciudadanos, a los trabajadores, a los obreros, a los empleados y los campesinos, "porque cuentas" dicen ellos, porque a los demás sí se les toma en cuenta, a los empresarios, a los dirigentes políticos, a las cúpulas empresariales, a las cúpulas religiosas, a ellos sí se les toma en cuenta, pero a ellos no.

La nueva administración debe ser sustentable, es decir, tomar en cuenta la economía, la sociedad y la ecología, recuerden que para hablar de sustentabilidad tenemos que hablar necesariamente de las tres esferas: económica, social y desde luego ecológica, porque si no, nos perdemos. Saben que Oaxaca es un estado del sureste de la República Mexicana, tiene algunos años que ya pusieron algunos campos eólicos para desarrollar la energía eólica y dijimos "a pues qué padre, es sustentable" pues resulta que no, resulta que con la promesa cuando se instalaron, que por cierto todavía son empresas transnacionales, todas son extranjeras van por la ganancia, entonces resulta que las comunidades cercanas no tienen luz y les prometieron que les iban a dar luz, entonces eso es una cosa impresionante, no se están tomando en cuenta las tres esferas, eso no es sustentable, sustentable tiene que beneficiar a la gente, a la sociedad, por eso la nueva administración tiene que tomar en cuenta la sustentabilidad, es decir, responsable desde el punto de vista social para mejorar las condiciones de vida de la gente, responsable con el medio ambiente, ¿qué le vamos a legar a las futuras generaciones? Y por supuesto que sea económicamente viable, tampoco hacemos un proyecto para perder.

La administración debe colaborar en la administración de bienes públicos globales como el agua y el aire, es decir, la administración de los bienes comunes, tenemos que rescatar eso, aquí, señalo estos dos como ejemplo nada más, el agua y el aire porque es un problema fundamental, pero no de nuestro país, es un problema mundial, es un problema de la tierra, es un problema que si nosotros acabamos con el aire y el agua, si es cierto seguimos respirando, pero ¿qué cantidad de porquerías respiramos? Ni siquiera lo sabemos, ¿cuál es la calidad del agua que bebemos? ah bueno, la buena es esta no, vean cómo no somos ecológicos, no, aquí está un ejemplo, esta es la buena y nos obligan a comprar el agua porque no tenemos la otra que debería ser buena.

¿Cuáles son las características que a mi juicio debe tener la administración del futuro?, ¿Cómo debe ser la administración del futuro? En primer lugar, una ad- 
ministración para la sustentabilidad, como ya he comentado, que toma en cuenta las tres esferas, a la económica, la social y la ecológica; administración para la convivencia en comunidad con espíritu ético, es decir, trabajando en el bien común.

La parte de la ética es fundamental y tal parece que nos hemos olvidado del actuar bien, de actuar en función de los demás, que es un espíritu ético, lo hemos perdido mucho y es necesario rescatarlo, administrar para mejorar las condiciones de vida de toda la población, es decir, ¿cuál es el nivel en el que nos encontramos? y ¿cómo podemos mejorar el nivel de la gente en cualquier circunstancia?, hablo de alimentación, educación, salud; que todo mundo tenga acceso a la salud, a la educación, a la vivienda, a la alimentación, al trabajo, es decir, a los derechos humanos básicos o fundamentales para la existencia humana.

Administrar para vivir mejor, no para obtener más ganancias, esto es un rompimiento de paradigma que hay que seguir trabajando. A los alumnos en estas escuelas de Contaduría y Administración les seguimos enseñando que deben trabajar para mejorar las ganancias de la empresa, olvidándose de todo lo demás, bueno pues las consecuencias están a la vista, tenemos que administrar la incertidumbre y el cambio, creo que en esta época que nos ha tocado vivir los cambios son impresionantes, son muy rápidos, las incertidumbres, los fenómenos inesperados, etc., debemos tomar en cuenta todo este tipo de cosas que nos pueden afectar, administrar con responsabilidad intergeneracional, casi no tomamos en cuenta esto, sobre todo porque tomamos en cuenta algunas ideas económicas de economistas que nos han legado y que ellos han dicho que lo importante es el corto plazo, que es lo de ahorita, incluso recuerdo una frase muy clara de John M. Keynes, decía que a largo plazo todos estamos muertos, pues sí claro, pero nosotros tenemos que pensar en las generaciones futuras, tenemos que pensar en nuestros hijos, en nuestro nietos, bisnietos,

Bueno pues ahí le dejaré yo, por lo menos tres generaciones más, administrar y controlar los riesgos de todo tipo, económicos y financieros, ambientales, sanitarios, etc., eso es una de las cosas que yo he comentado mucho aquí en la Facultad y en el posgrado, hay mucha y buena administración de riesgos financieros, habla de nuestra contabilidad creativa, cómo envolver algún fraude, algunas cosas de esas, ustedes conocen las empresas, Enron, etc., todas esas empresas.

Tenemos que pensar en qué vamos a hacer, qué va a pasar; ejemplos hay muchísimos, nosotros tenemos aquí un ejemplo, me refiero a la compañía que está saliendo del Distrito Federal, por una carretera que va al estado de Puebla y que año con año se desborda y no hacemos nada para corregir este problema, y es un riesgo calculado y así como eso hay muchos otros, los económicos, los financieros, los ambientales, los sanitarios, de todo tipo. 
Administrar organizaciones no lucrativas como las cooperativas, las asociaciones, así como organizaciones que fomenten la economía solidaria, tal parece que el espíritu del capitalismo es una empresa para obtener la máxima ganancia, ¿qué no puede haber otro tipo de empresas?, estamos acostumbrados a esto, y nos conformamos con lo que sucede, ah bueno pues ese es el precio que tengo que pagar, vas a comprar algo y pagas el precio por ese algo; ¿por qué no pensar en organizaciones no lucrativas?, las cooperativas fundamentalmente, las asociaciones y organizaciones que fomenten una economía solidaria, una economía para todos no para unos cuantos.

La administración debe cambiar, porque la economía, la sociedad, la política, las organizaciones no son las mismas del siglo pasado, estamos ya en la segunda década del siglo XXI, las cosas han cambiado de forma impresionante, recuerden las bases de la prospectiva, pensamos, actuamos, administramos el cambio, es decir, se trata de administrar el futuro, entonces sí, estamos prospectivos, la administración del futuro, llegamos a eso, pero bueno, implica un montón de cosas, implica en primer lugar pensamiento, luego acción, administrar el cambio, administrar el futuro como una consecuencia de todo lo que estamos comentando.

El administrador del futuro en consecuencia debe fomentar valores como la empatía, nos hemos olvidado de la empatía, la empatía es ponerme en el lugar del otro, se usa mucho por ejemplo, cuando una persona sufre; utilizar la compasión, nos hemos olvidado de la compasión, compasión es padecer con, te acompaño con tu sentimiento; solidaridad, apoyarnos los unos a los otros, trabajar en equipo, no ser egoístas, no nada más todo que venga para acá, esa actitud egoísta es una actitud que yo llamo de los marsupiales, como los canguros, que destapan la bolsita, pero ¿han visto que un canguro saque y abra la bolsita para los demás?, ¿no la saca verdad?, entonces nosotros no tenemos que ser canguros eh, tenemos que ser solidarios, cooperación y ayuda mutua; y el asociacionismo, hay que fomentar el asociacionismo en todos los sentidos, es lo que se llama el emprendimiento social, organización de empresas que no tengan como objetivo fundamental el lucro; por supuesto la democracia participativa, podemos decir democracia participativa como también podemos decir administración participativa.

Es decir, tomar en cuenta a todos, todos tienen un rol que jugar, pues hay que tomar un 50, nada más hay que tomar el 50, por ejemplo en la administración pública para cobrar los impuestos, para aumentarles los precios, no para eso, sino para la toma de decisiones, una toma de decisiones colegiada, que no sea de una sola persona, sino que sea colegiada en consenso y discutiendo, analizando, pensando, actuando, que todo el mundo tengamos el mismo objetivo en común, 
Por lo tanto, el administrador del futuro debe tener pensamiento anticipatorio, complejo, holístico, prospectivo, estratégico, sustentable, humanista y ético, eso es lo que nosotros enseñamos en la prospectiva, eso es lo que pretendemos ser.

Si nosotros nos decimos que somos prospectivistas, somos prospectivos, debemos tener estas características, un pensamiento anticipatorio: qué pasa si, qué puede ocurrir, tratar de prever; complejo, hay una interrelación de todas las cosas, ya no se justifica la separación por segmentos, por estatus, por disciplina, la economía por un lado, la administración, las finanzas, todas las cosas por separado, no, todo mundo tenemos que entender que todo está relacionado, hay una íntima relación, por lo tanto debemos tener un pensamiento que desarrollo el sistémico, que interrelacione las disciplinas, interdisciplinario, transdisciplinario, multidisciplinario; y por supuesto, pensando en la totalidad, que es ese dato.

Bueno pues lo que pasa en la tierra, lo que pasa en nuestro planeta, yo diría, lo que pasa en el universo, lo que pasa en el cosmos, tendríamos que irnos más allá, hacer un pensamiento holístico que abarque la totalidad; prospectivo, pensar siempre en el futuro, en el mañana, en lo que puede seguir más adelante, 10, 20 años; estratégico, no puedo modificar todo pero si puedo tener estrategias para cambiar lo fundamental, cuáles son los elementos que van a incidir sobre todo lo demás, entonces vamos a hacer cuestiones estratégicas, una estrategia que me permita ir cambiando, es decir, hacer planeación estratégica, que tienen que hacer ahorita para que en 20 años tenga los resultados que yo quiero, hay ya que trabajar desde ahorita para lograr eso que quiero en el 2030 por ejemplo; sustentable, he estado repitiendo que debe incluir las tres esferas, económica, social y ecológica, por supuesto centrada en el ser humano con un gran espíritu ético. Muchas gracias. 


\section{LA CONSULTORÍA EN PROSPECTIVA EN MÉXICO: MORAIMA CARVAJAL}

uenos días, muchísimas gracias a la Doctora Guillermina Baena por la invitación y agradezco la presencia de todos ustedes en este foro. Vamos a enfocar la plática en seis aspectos fundamentales relacionados con la consultoría en prospectiva, en México. Esos seis aspectos son: 1) ¿quiénes compran prospectiva?; 2) ¿qué compran?; 3) ¿qué enfoques metodológicos demandan?; 4) ¿qué tanta utilidad le otorgan a estas consultorías?; 5) ¿qué más pueden comprar para futuros? y 6) ¿quiénes venden prospectiva?

Ante la primera interrogante, ¿quiénes compran prospectiva en México?, señalamos dos compradores fundamentales. Por una parte está la Iniciativa Privada, representada en las grandes empresas (especialmente multinacionales) y por las representaciones gremiales de cámaras y/o asociaciones. El otro comprador es la Administración Pública, que se expresa en las Secretarias (Gobierno Federal), Presidencia (Oficina de la Presidencia), los Gobiernos de las Entidades y las instituciones públicas. Cada comprador obedece a razones distintas ante sus demandas en prospectiva. Veamos cada caso.

Generalmente la iniciativa Privada compra: a) prospectiva orientada al mercado: que se refiere a la detección de oportunidades y riesgos (grandes empresas, cámaras sectoriales); b) prospectiva orientada al cabildeo: se expresan en planes de acción sectorial que requieren de mejoras en políticas públicas relacionadas con el futuro del sector (cámaras y/o asociaciones); c) prospectiva tecnológica: para nuevos productos, innovación de productos y/o procesos; d) prospectiva institucional: la compran en menor medida, es una especie de reingeniería empresarial y/o sectorial. En todos los casos, compran prospectiva-estratégica y/o estudios de futuros y estrategias. A la iniciativa privada les interesan las acciones que pueda emprender para mejorar el porvenir que se avizora. 
Entonces una de las opciones de trabajo en consultoría es la Prospectiva orientada al cabildeo, za qué me refiero con esto? Por ejemplo, desde el punto de vista sectorial, bien sea determinado sector productivo o cadena productiva, hacen propuestas de prospectiva estratégica. Generalmente no trabajamos, les aclaro por si acaso, no muy largo plazo, se trabajan plazos cortos, de apenas de 10 años, de 15 años en este tipo de consultoría, en uno que otro se trabaja a 20 años, pero son plazos generalmente muy, muy cortos... si tenemos en cuenta que la prospectiva, al menos en la mayoría de estos ámbitos, es en verdad de largo plazo.

Entonces qué pasa en este caso si nosotros estamos hablando, por ejemplo, de una cadena productiva. Puedo poner algunos ejemplos que he trabajado en los últimos años de la industria del plástico, la industria del calzado o del caso del sector transporte. En estos casos, ellos buscan también tener en cuenta la parte regulatoria. Para el sector empresarial, esto es muy importante, hay que considerar cuál es el marco legal regulatorio que se necesita para que esas acciones a futuro puedan llevarse a cabo. Para el sector empresarial es fundamental, entonces son propuestas que van acompañadas también, evidentemente, de una parte que tiene que ver con las reformas legales del caso. ¿Y esas reformas legales las puede efectuar el sector empresarial? Claro que no, en su mayoría es competencia del poder legislativo, otras son responsabilidades que están orientadas al poder legislativo federal. Es por eso que parte de estas propuestas, de una u otra manera, vienen acompañadas de lo que debe ser la estrategia también de cabildeo. Vale decir, si esas reformas son necesarias para que esta estrategia, producto de la prospectiva pueda echarse a andar, necesita un marco legal adecuado. Entonces ahí funcionan muy bien la labor de las cámaras empresariales, independientemente de que sean grandes empresas, que sea el caso de Nestlé, que sea el caso de la Coca Cola, que sea el caso de Bimbo, que sea el caso de LALA, por ejemplo, ellos también se apoyan mucho en las cámaras. Eso no resta que las grandes empresas también compren cabildeo y lo compran por cuenta propia, pero se apoyan en las cámaras también para esos procesos donde se busca un marco legal adecuado para los negocios. Entonces la detección de ese marco legal adecuado, puede haber sido producto de un estudio prospectivo de una cadena productiva, de un sector productivo o simplemente de la prospectiva de una empresa.

¿Qué más compran la iniciativa privada?: prospectiva tecnológica. Es toda la parte que tiene que ver con la innovación de productos y de procesos. No obstante, y aquí hago la aclaratoria, en muchos casos estas empresas gozan de sus unidades de inteligencia tecnológica, por supuesto las grandes empresas, y desde allí realizan sus procesos de prospectiva tecnológica. A veces la consultoría les 
ayuda también, hace las veces de una especie de think tank, que ayuda a verificar algunas de las cosas que las empresas están haciendo. Pero, insisto, son más bien procesos internos, y la consultoría es un respaldo, que también se puede expresar en una consulta a expertos.

¿Qué más compran la iniciativa privada?: prospectiva institucional. Y ésta la compran en menor medida. En muchos casos en el país, lamentablemente, hay una confusión, de verdad impresionante, porque realmente a veces no es prospectiva como tal, sino sencillamente son planes estratégicos o procesos más bien de reingeniería. Son planes de 6 años por ejemplo, o de los 8 años, pero entonces alguien por ahí dice "no, déjenme ponerle el nombre de prospectiva y le pongo prospectiva institucional". Pero realmente cuando analizas, desde el punto de vista hasta del proceso metodológico como lo hacen, cómo lo están llevando a cabo, te das cuenta de que son procesos más bien de planeación estratégica o en algunos casos, de reingeniería.

En todos los casos de prospectiva estratégica o estudios de futuros, estos van acompañados de la estrategia. A las empresas les interesan mucho las acciones, no más rollos sobre su futuro y qué va a pasar. No, no, no, y te dicen: "a mí eso me lo aterrizas, eso sí, las decisiones las tomo yo". Eso es muy importante, finalmente ellos, los empresarios son los tomadores de decisión, esa es una de las premisas fundamentales de la prospectiva, me imagino que ya en el tiempo que llevan estudiando la han visto. Uno como consultor o participante dentro de una empresa, haciendo prospectiva, no necesariamente uno toma las decisiones estratégicas. Uno determina opciones estratégicas, pero quien decide los detalles del cómo y los calendarios de recursos, son otros. Son los empresarios. Ellos demandan acciones, acciones que les den luz, luz por donde entrar al futuro, pero insisto, el detalle de esas acciones es competencia de los empresarios.

En el caso de la Administración Pública, compran: a) prospectiva territorial: proyectos de gran visión, proyectos de desarrollo ecológico, ordenamiento del territorio (zonas costeras, marinas...), previsión de riesgos y desastres naturales; b) prospectiva sectorial: prospectiva energética, en recursos ambientales, en salud, en nutrición...; c) prospectiva política: tendencias en asuntos subversivos y terrorismo, perspectivas de sectores estratégicos y su infraestructura; vinculada a organismos militares y de inteligencia (defensa nacional) y d) prospectiva institucional: la compran en menor medida, generalmente es más planeación estratégica que prospectiva.

En todos los casos son estudios de futuro. Le interesa a la Administración Pública destacar el diagnóstico a fin de "vender" ante los actores y la opinión pú- 
blica especializada que la propuesta de acciones responde a consideraciones de la situación actual y el escenario tendencial. Tienden a estar vinculados al período de la administración pública del caso.

La Administración Pública, acá en el país, hace muchos intentos de Prospectiva territorial. Me atrevería a decir, quitándole el término de prospectiva, que realiza muchos estudios de futuro territoriales. No necesariamente son prospectiva, son estudios de gran visión y hay algunas normas y leyes en el país que obligan a los territorios necesariamente a hacer estudios del futuro. En algunos casos, estos estudios transcienden el periodo administrativo del gobierno de turno. En el país se realizan estudios de ordenamiento territorial, de ordenamiento ecológico, de zonas costeras y marinas. También hay una tendencia de estudios que ha crecido en los últimos años, es muy reciente, que tiene que ver con la previsión de riesgos y desastres naturales, ¿por qué?, porque en la mayoría de los países de la región lo hemos vivido, vivimos las grandes consecuencias del cambio climático y se pueden dar lluvias, lluvias que se pueden convertir en torrenciales y se llevan a los pueblos, porque sencillamente el río busca su curso natural. Entonces parte de lo que se está haciendo ahorita en esta materia son estudios prospectivos de riesgos naturales.

También en la Administración Pública se demanda la Prospectiva sectorial. Quizás no exactamente como prospectiva, sino más bien estudios de futuro con mucho énfasis en proyecciones. Por ejemplo en la parte sectorial, nosotros acá en México la podemos conseguir en Prospectiva del sector energético, y podemos conseguir de manera más específica en el sector eléctrico. También podemos conseguir prospectiva de la administración pública reflejada en estudios de la alimentación, la agroalimentación, la prospectiva de recursos naturales, la prospectiva hídrica. Hay muchos tipos de prospectiva de esta naturaleza que compra la Administración Pública.

Aprovecho para realizar una aclaratoria. En estos casos, de prospectiva sectorial, la ley no obliga a hacer este tipo de prospectiva, pero sí pueden ser acciones que determinadas Secretarias del Ejecutivo Federal se comprometan a realizar. El marco de la ley tiene su base en el sistema de planeación del país, que en función del Plan Nacional de Desarrollo obliga a la realización de programas sectoriales. Pero estos programas sectoriales van de acuerdo al periodo de la Administración Pública. En el caso de México, a nivel federal, son de seis años; entonces los programas sectoriales tienden a ser de seis años. Hay algunas Secretarías, vale decir Ministerios para ustedes, que son un poco más atrevidos, y dicen, "iy por qué no nos echamos más bien un estudio de largo plazo?" Entonces van a conseguir en 
el país, por ejemplo, ese tipo de investigaciones, que como muchos estudios del futuro en la región de América Latina no necesariamente se están revisando con la continuidad que requiere.

Seguimos con los otros estudios que compra la Administración Pública: prospectiva política. Esta prospectiva política es principalmente prospectiva de defensa nacional, es la parte de la Administración Pública más orientada a la parte de la seguridad. De nueva cuenta, así como les decía de la prospectiva tecnológica de la iniciativa privada que a veces se hace más en casa y con el apoyo de los think tanks, aquí también ocurre un poco eso. Es prospectiva de seguridad nacional que puede recibir de un consultor externo, el respaldo, por ejemplo, para el proceso metodológico. Eso sí, las acciones estratégicas son sólo de la incumbencia del organismo público.

También la Administración Pública compra prospectiva institucional. De nueva cuenta, la compran en menor medida, y a veces es más planeación estratégica y va en función en muchos casos del periodo de la Administración Pública. Puede ser a veces hasta más corto, lo hacen casi como un plan operativo de tres años. Pero no se crean, aquí en México hablar de tres años es casi hablar de prospectiva para algunos. Y eso se los aclaro, porque que hay mucha gente, de veras, que habla de prospectiva y son escenarios y/o acciones para el próximo año.

Pensamos que acá en México van a realizarse elecciones el próximo año, en el 2015, elecciones regionales, locales. Y son muchos los despachos de consultoría política que hablan de la prospectiva electoral. Perdón, ipero eso sólo puede ser el análisis electoral del año que viene!, Hablar utilizando esos términos... entonces es que vende, a lo mejor vendes si dices que es prospectiva electoral.

¿Y qué les interesa en estas compras de prospectiva a la Administración Pública? Y como yo digo, no es que no me lo contaron o que lo leí. No, lo viví, lo he vivido, yo les estoy hablando de mi experiencia, yo tengo un poco más de 20 años haciendo prospectiva, mejor no les digo cuanto más. En el caso de la Administración Pública interesa muchísimo la validación, pero esa validación tiene un peso político, porque finalmente si van a hacer una propuesta bien sea sectorial, o es una propuesta desde la Oficina de la Presidencia y van a hablar del México de 2050 como mínimo, porque hablar del 2030 está a la vuelta, en fin en cualquier caso necesitan validar. Insisto, para ellos, para la Administración Pública, este tipo de proyectos necesita validarse, y aquí lamentablemente se empieza a caer en un error. A ustedes, me imagino, que en distintas pláticas ya les han comentado, que es un exceso querer que todos validen, que todos participen, buscar que cientos validen en el facebook, o en la página web donde están validando; y ya con eso 
la hice. Es decir, "ya con eso la hice", no importa el contenido, no importa si las acciones son las más o las menos adecuadas. ¿Por qué?, porque a la Administración Pública le interesa legitimar sus proyectos, señalar que son producto de una amplia, amplia consulta. Les interesa neutralizar a los generadores de opinión, que de alguna u otra manera a lo mejor puedan causar ruido en ese proyecto. Pero finalmente, lo que en muchísimas ocasiones le interesa a la figura pública que manda a realizar el estudio prospectivo o al representante de la Secretaría, es su capital político, porque éste está en juego en función de esos seis años. En resumen, en todos los casos de estos estudios de futuro les interesa, por una parte, destacar el diagnóstico a fin de "vender" ante los actores y la opinión pública especializada que la propuesta de acciones responde a consideraciones de la situación actual y el escenario tendencial, y por otra parte, interesa destacar que se ha realizado una amplia, amplísima consulta con todos los actores involucrados.

Pasemos ahora al tercer aspecto de nuestra plática: iqué enfoques metodológicos son los que se demandan con más frecuencia? Y vamos paso por paso. Primero hablemos de la Iniciativa Privada y luego de la Administración Pública. En el caso de la iniciativa Privada, vamos a analizar dos asuntos: a) los enfoques que estén orientados a la efectividad y la eficiencia en los recursos y b) los que proporcionen una agenda de acciones, seguimiento y validación. En el caso de los que estén orientados a la efectividad y la eficiencia de los recursos son muy importante. A los empresarios les interesa que esos recursos, materiales, financieros, humanos y tiempos, se utilicen lo mejor posible. Y como dicen muchos de ellos, que proporcionen también de nueva cuenta, acciones, seguimiento y validación. Es por ello que en estos enfoques orientados a la eficiencia y efectividad de los recursos, los soportes de dato duro, el empleo de modelos de pronósticos y proyecciones, pasan a ser fundamentales. Asimismo demanda el empleo de fuentes oficiales nacionales e internacionales, con bases robustas, históricas y proyecciones .Y aquí me voy a detener tantito.

En mi experiencia realizando consultoría en prospectiva, he observado que al sector privado le interesa mucho el dato duro, las series históricas, las proyecciones; quizá porque en los procesos de negociación, hasta en los procesos de negociación interna para "vender" el proyecto, requieren ese respaldo. Esto sin desmeritar las consultas a expertos. Pero el respaldo del dato duro es súper importante, porque ayuda, reitero, tanto en el proceso de negociación interna, como cuando estas cámaras de representación empresarial van a mostrar su estudio prospectivo ante representantes del Ejecutivo Federal y el Poder Legislativo, poderes de los que demandará un marco regulatorio adecuado para el crecimiento de sus sectores 
productivos. Súmenle si lo que se está haciendo implica un proceso de negociación no sólo con el ejecutivo federal, con el legislativo federal, sino con los ejecutivos de los estados, con los legislativos de los estados. Entonces si van ante estos actores y solamente dicen "mire este es el escenario, por aquí vamos, no significa que vamos a estar mejor y con este podríamos estar peor, pues podría suceder que se caiga un poco el desarrollo económico, que el sector se venga abajo". Entonces los funcionarios lo que van a preguntar es cuánto se va a venir abajo, que es lo que me quieres decir, cuánto, dime cuánto, cuáles son las proyecciones para el 2025, cuánto es, cuál es la variación que estamos esperando. En fin, sí interesa muchísimo la parte de datos duros, es un sector que al menos aquí lo demanda, no sé cómo será en otros países, como en Colombia. Sólo sé que en los casos de España, Chile y México, pasa esto. Yo hablo de las experiencias que conozco y he trabajado.

Por otra parte a los empresarios en México, y también sé que a empresarios de otros países, les interesa la credibilidad de las fuentes. Por eso, se emplean fuentes oficiales nacionales e internacionales. No fue que Moraima Carvajal por ahí dio una declaración y dijo que el valor de determinada variable sería de tanto o escribió algo al respecto. Y yo voy a aceptar a Moraima, no. Yo puedo ser un experto haciendo consultoría, pero yo no soy el Instituto Nacional de Estadística del país.

Entonces hay que buscar, apoyarse en las fuentes oficiales. En mi experiencia, trabajamos mucho con mega tendencias, esas grandes tendencias que van guiando, diríamos el futuro de sectores y de desarrollo. Y además de lo que representan la mega tendencia como impacto para la sociedad, nos interesa ver su impacto reflejado en determinadas variables. Es por ello que muchos consultores en prospectiva tenemos la costumbre de acompañarnos con las estadísticas de todos los organismos de Naciones Unidas, que ayuda mucho para este tipo de consultoría. Es necesario que un especialista en prospectiva maneje muy bien el análisis estadístico. Asimismo utilizamos la ocde como fuente, también para el caso de México que pertenece a la OCDE, ayuda muchísimo. Igual emplear los índices del Foro Económico Mundial ayuda, aunque luego se produzcan los debates de cómo está hecha su metodología y si hoy me indica que el país está en el número 54 del ranking de competitividad y mañana que en el 58, que si ahorita le suman 5 países y luego le restan... En fin, es importante respaldarse en fuentes oficiales de alta credibilidad, importa muchísimo que esas fuentes además tengan series históricas desde el punto de vista de la estadística, y luego podamos utilizarlas para poder hacer las proyecciones o modelos de pronósticos.

De los enfoques metodológicos que están orientados a la efectividad y la eficiencia en los recursos, la iniciativa privada demanda también sencillez metodológica, 
que responda hacia dónde y por dónde; diagnóstico conciso y breve, escenarios con soporte argumental y datos duros, y consulta a expertos (internacionales y nacionales). De la sencillez metodológica, que sea sencillo, que uno le diga esto es, hacia dónde y por dónde, así de simple, sin mucho rollo. Demandan un diagnóstico conciso y breve porque de alguna manera ellos, como sector o cámara o empresa, tienen parte de ese diagnóstico, lo manejan. De los escenarios, les interesa el soporte argumental y los datos duros. En mi experiencia me ha tocado utilizar, porque depende de los recursos, los ejes de Peter Schwartz para trabajar estos escenarios, que no sólo se pueden limitar a la descripción cualitativa sino que importa muchísimo el dato duro.

¿Si conocen los ejes de Peter Schwartz? Sí, verdad, claro que sí, todos lo conocemos. Bien, es un método sencillo, en el caso del sector empresarial se lo pintamos y le decimos lo que tiene, "aquí tienes, son dos variables, variables independientes y aquí tu cuadrito uno, dos, tres y cuatro". Ah, pero no podemos dejarlo así, en una narración porque ellos nos van a decir: "ajá, pero ábreme cada uno de esos escenarios con datos duros, ábreme el tres con estos datos duros, ábreme ese cuatro con estos datos duros, no me eches rollo, yo quiero ver los datos". Y eso es muy importante, sigue siendo una sencillez el método pero hay que soportarlo con datos. "Sopórtame el caso de los escenarios", dirían ellos. E igualmente si nos vamos y utilizamos completito el modelo de elaboración de escenarios de la prospectiva estratégica de Michel Godet, de la escuela francesa, esos escenarios igual tienen un soporte argumental y tienen un soporte de datos duros, que también para ellos, los empresarios, es importante.

En el caso de la consulta a expertos, existe muy buen nivel de confianza con los empresarios. Confían en los expertos que recomendamos. Y eso es muy bonito de verdad, es muy bonita la experiencia que he tenido en relación con los expertos, a diferencia de la Administración Pública donde a veces te dicen, me vas a consultar a fulano, a zutano, o inclúyemelos si es posible. En este caso (el de la privada) hay un nivel de confianza cuando uno propone una lista de expertos. Es decir, confían en los consultores; en la selección de esos especialistas en el tema, esto es porque el consultor sabe que ellos son especialistas. Aquí, en México, esto de verdad, en el caso de la iniciativa privada, hay un nivel de confianza: no te imponen sus expertos.

Pasamos ahora a los enfoques metodológicos que para la Iniciativa Privada les proporcionen una agenda de acciones, seguimiento y validación. Esto se expresa en: en una especie planeación estratégica (mediano plazo); en el diseño de estrategias y acciones; que incluyan perspectivas del marco jurídico, de las reformas 
que se requieren para el largo plazo; seguimiento de agenda de acciones; en todos los casos, corresponsabilidad en el quehacer de la acción, y manifestación abierta del compromiso, (en menor medida). Explico.

En lo posible, además de que pueda ser prospectiva y muestre los escenarios de largo plazo, para los próximos veinte años por ejemplo, les interesa también el más acá, acciones estratégicas. En lo posible que sean estrategias para el mediano plazo, seis años, ocho años, que de ellas puedan planear sus acciones del corto plazo, que les van a ayudar a alcanzar el mediano plazo y que me les van a ayudar, por supuesto, a alcanzar ese escenario al que apostaron que está en el 2050 o 2030. Es diseño de estrategias y direcciones, esto es muy importante. Lo que les decía, a la iniciativa privada les interesa: dime por dónde y del detalle me encargo. Es decir, no llegamos a un nivel de un plan operativo, donde ya estamos por supuesto poniendo cuáles son los recursos y cuáles son, diríamos los tiempos exactos y así un nivel de presupuesto, no, pero si requieren los empresarios que al menos se haga un plan, diríamos, de las acciones que son fundamentales y de la corresponsabilidad en el quehacer de la acción.

En los últimos años, sobre todo con las cámaras empresariales que me ha correspondido trabajar, hemos incorporado otro factor. Aunque no fue fácil se los confieso, pero hemos incorporado el compromiso de las personas o instituciones; de quiénes son los corresponsables de esas acciones fundamentales al menos para próximos ocho años, de tal manera que exista mayor probabilidad de aterrizar las acciones. ¿Y por qué? Pues porque se puede quedar en, jah! bueno por aquí vamos, sí, iaja! Pero cómo lo aterrizan, entonces nosotros les ayudamos. Aunque no tomamos las decisiones estratégicas, sí ayudamos un poco en lo que tiene que ver con los actores y su relación con los compromisos, es decir qué va a hacer quién. Pero especialmente, "a qué me comprometo en el mediano plazo para avanzar en el escenario apuesta y contribuir al desarrollo del país".

Les platico una experiencia, diríamos muy muy reciente, realmente muy reciente, hace como unos cinco años aproximadamente. Estaba trabajando un proyecto prospectivo, del sector industrial del país, le cambiamos un poco el nombre para no ponerle prospectiva. Les propuse al despacho que empezáramos a trabajar con el término agenda, porque finalmente una agenda requiere el compromiso de "alguien" para cumplirla. La verdad, yo he dado algunas vueltas también en mi vida, y en los últimos años, toda esta experiencia que me ha dado la prospectiva, la he ido canalizando a trabajar más con la prospectiva personal, la prospectiva de la gente, porque finalmente si nosotros como personas no tenemos un proyecto de futuro, cómo podemos vender prospectiva o cómo podemos hacer prospectiva. 
Me he dado cuenta de que las limitaciones a veces para avanzar en estos proyectos de prospectiva, se dan precisamente por esto, porque la gente está enraizada, la gente se resiste al cambio, como que le molesta el cambio; entonces les propuse en ese proyecto, que llamamos agenda, trabajar con el compromiso.

Recuerdo que planteamos que los actores se comprometieran, no solamente en el quehacer de sus competencias y limitaciones. Como les decía, en muchos de estos casos de la iniciativa privada se requieren reformas desde el punto de vista legislativo o algunos asuntos que tienen que ver con normas y regulaciones que le corresponden al ejecutivo. Hubo, de veras, en el sector empresarial respuestas así como que: "pero yo, yo por qué me voy a comprometer, si yo lo que quiero es que (en este caso lo que tenía que ver con normas y leyes por cierto), es que ellos avancen con los cambios de reformas y de normas". Pero ¿cuál es su compromiso, qué van a hacer ustedes?, insistíamos. No les estábamos pidiendo que todos se fuesen a cumplir de buenas a primeras, los principios del Pacto Mundial de Naciones Unidas; pero a qué te comprometes, mínimo que vayas avanzando por ahí, en esos diez principios del Pacto Mundial ${ }^{1}$. Y no fue fácil, de veras, se los comento. No fue fácil y de ahí empecé a manejar mucho más esto, es decir, no sólo el corresponsable de la acción, sino una corresponsabilidad más grande, una corresponsabilidad que tenga que ver con el desarrollo del país, no es solamente que me comprometo a generar 50,000 empleos más, sino el compromiso en el marco de la sostenibilidad o de los avances en el Pacto Mundial. Una manifestación abierta del compromiso y la corresponsabilidad.

En todos los casos, en los enfoques metodológicos que demanda la Iniciativa Privada, buscan la legitimidad de lo que se hace, con alta participación de actores clave; promover la asertividad, pensamiento crítico en sus grupos y los actores involucrados; y asimismo que esa metodología a emplear haga un uso racional y oportuno de los recursos. Es una legitimidad hacia la parte interna e igualmente hacia el resto de los actores con los que están relacionados, bien los proveedores, otras empresas, las cámaras o las Secretarías también. Porque, finalmente, si luego van a negociar con las Secretarías porque parte de las demandas corresponden a éstas, necesitan igualmente que les validen. Esta es una parte que a ellos les interesa mucho de ese proceso de legitimidad.

\footnotetext{
${ }^{1}$ El Pacto Mundial de Naciones Unidas (Global Compact) es una iniciativa internacional que promueve implementar 10 Principios universalmente aceptados para promover la responsabilidad social empresarial (RSE) en las áreas de Derechos Humanos, Normas Laborales, Medio Ambiente y Lucha contra la Corrupción en las actividades y la estrategia de negocio de las empresas. Con más 12.000 entidades firmantes en más de 145 países, es la mayor iniciativa voluntaria de responsabilidad social empresarial en el mundo.
} 
Algo que caracteriza al sector empresarial es su comportamiento muchas veces asertivo, además de un pensamiento de verdad crítico. Vale decir: "puedo decirte en buenos términos lo que quiero, lo que necesito, lo que busco, respetándote, no agrediéndote". Y eso, es decir, es criticar en el buen sentido de la palabra, eso lo tiene mucho la iniciativa privada y de nueva cuenta un uso racional y oportuno de los recursos.

Recuerdo que en mi estancia en el país Vasco, hablaban de la posibilidad de realizar un proyecto en año y medio, de dos años para la realización de un proyecto de prospectiva, muchos casos para sector empresarial, porque también ahí había una continuidad, quizás la última parte era el sistema vigía. Entonces yo no entendía por qué se podía extender tanto la realización de proyectos como estos. Pero acá es diferente, no le digas a una empresa que te vas a tardar dos años haciéndolo, no, olvídalo. Se le cae el "changarro", así de simple, no, pues no. Acá los tiempos de la iniciativa privada para este tipo de consultoría tienden a ser más cortos, 6 o 7 meses, por ejemplo, esa es mi experiencia, a veces te puedes extender un poquito más, y a veces necesariamente tienes que hacerlo en menos, en cinco meses. Entonces por eso, de nueva cuenta, es necesaria la claridad y la sencillez metodológica, manteniendo una rigurosidad metodológica que es fundamental y debe responder, diríamos, a estos principios que son los que ellos solicitan, de legitimidad, pensamiento crítico, y uso racional y oportuno de los recursos.

Bien. Vamos ahora con la Administración Pública, ¿qué enfoques metodológicos demanda la Administración Pública? Principalmente: a) los que estén orientados a amplias consultas y promoción de las mismas; b) los que conlleven metodologías propuestas por la misma administración pública y c) los que proporcionen agenda de acciones y validación. Vamos con la primera de estas demandas de la Administración Pública: amplias consultas y promoción de las mismas. En lo posible, mientras más y más consulten mejor. Si le consultamos a los cien millones incluyendo a niños recién nacidos, perfecto. ¿Por qué? Porque esto les permite validar el estudio ante la opinión política y la opinión pública. Entonces dicen: "es que nosotros consultamos, no fueron a los cien, pero sí la población económicamente activa que está cerca de los 47 millones" Y eso, para ellos, valida el estudio. En los últimos años en el país ha empezado a ocurrir mucho esto, validar por validar sin saber a quién; y eso, de nueva cuenta, tiene que ver -quizás-con un redescubrimiento de la planeación participativa en el país.

La prospectiva per se es planeación participativa. Es decir, ya lo trae implícito desde el punto de vista de los modelos, de los enfoques. Hacer prospectiva estratégica sin hacer planeación participativa es imposible. Claro, yo puedo hacer algunos estudios de futuro sin necesidad de usar la planeación participativa, que 
es diferente. Entonces, la Administración Pública emplea mucho supuestamente la "planeación participativa". Por ejemplo, coloca unas consultas a través de internet: coloca los temas en la red y tú vas y participas, aunque no tenga ni idea del tema, pero igual opino y valoro. Y lo he comprobado, me ha pasado, yo he probado estas plataformas de consulta como simple ciudadano.

Hay algunas consultas, no sé si recuerdan, que cuando uno llena estas consultas por internet, si yo utilizo determinada computadora, solamente se graba un registro; porque te registran prácticamente tu dirección de IP. Pero en la mayoría de estas consultas de la Administración Pública, tú puedes entrar tantas veces como quieras y participar. Y no es que me lo han contado, de nueva cuenta, yo misma me digo: déjame volver otra vez a votar, a llenar todo esto y voto de esta manera. Y me dice la plataforma escoja usted los temas que considera de interés para el 2018-2025, y ahorita señalo unos y luego en otra entrada señalo otros. Y yo, Moraima Carvajal, si tuviera todo el día libre puedo participar 50 veces. Allí hay una deformación, lamentablemente, en estos estudios de futuro de la Administración Pública. En otros casos, para la consulta a expertos, piden que en lo posible que sean personajes que están en la palestra pública, y si están vinculados a la opinión pública, mejor todavía. Sienten que eso le da validez al proyecto. Y les interesa mucho la difusión del proceso, muchísimo, en este caso ellos a eso le dan mucho peso. Y por supuesto que les interesa que ese enfoque metodológico a emplear integre el corto y mediano plazos. ¿A qué me refiero con el corto plazo? En estos casos estamos hablando de lo que pueda ser un añito o dos añitos, y en el mediano plazo al menos unos cinco, seis años. En resumen, buscan la legitimidad de lo que se hace en función de la cantidad consultada y no necesariamente de la idoneidad de la consulta, y que el estudio les permita contar con acciones para el periodo administrativo que están viviendo.

Les platico un ejemplo. Hace poco, comenzando este gobierno federal, este gobierno comenzó en el 2012, se realizó una consulta para ver de una u otra manera el punto de vista del futuro acerca de un sector particular. Se trataba de estudiar el futuro de la ciencia, tecnología e innovación y la educación superior; y fue una iniciativa del Senado de la República. Se hizo una página web y se votaron cinco, cuatro temas. Cuando uno veía los temas, y en mi caso en particular que he trabajado en prospectiva de la educación superior, ciencia tecnología e innovación; bueno, cuando uno veía esos temas tan generales, pero tan generales como "tecnologías de información", se entiende que es poco sustantivo lo que saldrá de ese estudio. Claro, pero eso sí, participaron tantos millones de personas... Y eso es lo que importó. Luego tendría que haber un trabajo de gabinete para aterrizar esos grandes temas, porque de lo contrario, reitero, el estudio sería poco sustantivo. 
También al hacer prospectiva para la Administración Pública, en muchos casos, las metodologías a emplear son propuestas por la misma Administración Pública. En muchos casos los estudios de prospectiva o estudios de futuro en el país, tienden a pasar por licitaciones públicas. Una cosa son los términos de referencias de una licitación, que eso ustedes también lo tienen muy claro; y otro es la metodología propuesta. Por ejemplo, para el ordenamiento territorial existe una propuesta metodología, para el ordenamiento ecológico también existe una metodología. Pero, iqué ha pasado en el hacer, en la aplicación de la metodología a la que hay que ajustarse en esos contratos públicos? Y de nueva cuenta, no es porque me lo contaron, es porque lo viví. Sucede que como Secretaría o sector tengo a quizás la potestad de coordinar ese estudio de ordenamiento ecológico, y por tanto el diseño metodológico se lo entregan a un instituto de investigación de determinada universidad o determinado instituto de investigación. Ese instituto o el grupo de investigadores, generalmente mediante trabajo documental, de gabinete, arman la metodología que va a acompañar la licitación. Pero en muchas ocasiones sin una revisión rigurosa, que pasa a ser lo de menos, cuando observas que no hicieron pruebas de campo de su metodología. Entonces en programas de ordenamiento, cuando vas aplicar esas metodologías te das cuenta de que necesitas tecnología, pero a veces lo que necesitas es luz porque no llega esa comunidad que estás consultando. Por tanto, ese modelo metodológico, tan teórico y cerrado y con el más avanzado soporte tecnológico, no funciona allí.

Entonces ¿qué tiene uno que hacer? Pues readaptación, reimpresión, repensar. Reflexionar sobre cómo haces para cumplir con la metodología, que te están poniendo para cumplir con los términos de referencia y está en el contrato y no te puedes salir de allí, pero también para cumplir con un plan de acción creíble. Yo siempre aclaro, no son los términos de referencia los de la cerrazón, sino los que hacen las metodologías que "deben" emplearse. Es conveniente que prueben sus metodologías, para ver si son metodologías que funcionan con la gente, qué hacer para mejorarlas.

También la Administración Pública demanda metodologías que les proporcionen una agenda de acciones, en función -muchísimas veces- del periodo de la Administración Pública que les compete. Si son tres años, si son seis años, si son cuatro años. También requieren que ese estudio contemple una manifestación abierta al compromiso, que ayuda a "validar", a socializar el estudio. En muchos casos, se acostumbran las firmas de los grandes acuerdos. Entonces se refrenda el gran acuerdo del futuro de la educación y van todos los señores importantes. Eso seguramente les puede parecer semejante, porque en muchos de nuestros países 
se acostumbran a veces estos acuerdos, por el futuro de la paz, por el futuro de la lucha contra el narcotráfico, por el futuro de..., y así vamos.

Pregunta: " $i Y$ respecto por ejemplo a la diapositiva anterior en cuanto a los términos de referencia de anticipaciones, desde su experiencia qué tanta, digamos, flexibilidad se logra dejar allá al proceso metodológico que tiene una propuesta de prospectiva frente a ese modelo que la institución esté planteando. Es que uno a veces se encuentra con el proceso de licitaciones por ejemplo de la ONU en donde establecen unas metodologías específicas, y a veces uno piensa que tanto... la metodología de la prospectiva que ya se conoce frente a ese modelo que ellos están planteando, ¿qué tanto desde su experiencia encontramos que se pueda entrelazar o ya dependerá de cada consultor como tal?"

R: Mira, vamos a hablar de las licitaciones que están en buena ley, (no vamos a hablar de las licitaciones que vienen con nombre y apellidos, porque eso también a veces sucede en las licitaciones públicas). Si son licitaciones de verdad, en buena ley, donde se contrata un grupo para que haga la metodología y luego los términos de referencia, siempre existe una ronda de aclaratoria en esas licitaciones. Para esas aclaratorias debemos llevar las dudas, como ésta que planteas: qué tanta flexibilidad existe en el modelo prospectivo a presentar. Recuerdo un caso de Chile donde estamos como locos haciendo las preguntas para consultar. Y en mi caso particular, en mi experiencia, yo analizo mucho las dudas que se puedan presentar en el cómo hacerlo, porque finalmente esto me ayudará a determinar la oferta económica de la propuesta. Es lo que les digo, yo soy experta en el cómo se hacen las cosas en prospectiva, yo hago consultoría, y por tanto no desperdicio esa oportunidad de las aclaratorias. Entonces cuando leo los términos de referencia, y me digo "pero esto aquí, como que no me checa". Entonces, me llevo mis preguntas para la junta de aclaraciones. En este caso existe la posibilidad de que si usamos un modelo que responda a los principios que están en los objetivos y que nos pueda llevar a los resultados esperados, eso se puede agregar como el plus, en los añadidos de la propuesta técnica. Si me dicen, "si como no, usted puede añadir sus cambios" le pongo ganas y buscamos presentar la oferta con ese plus. Pero, cuando me dicen "no, mire, si es importante que...", ni modo, ahí ya se acaba. Pero en general, en estas licitaciones de la administración pública, e incluyendo algunos ejemplos de organismos multilaterales, se tiende a ser muy rigurosos, muy cerrados en las metodologías a emplear. Por ejemplo, aquí hubo una época en que los proyectos de gran visión territorial, se licitaban con una metodología específica. Y uno lo analizaba metodológicamente y no era más que planeación estratégica, casi que era un FODA. Así de sencillo. El FODA, como ya saben ustedes, 
han hecho y deshecho con él., Pero, ¿qué tenían esos proyectos de gran visión? No había visión, no había escenarios,.. Pero bueno, en otros términos, si quieres participar en estas licitaciones tienes que adaptarte a las reglas. Es por ello que uno como consultor en prospectiva debe manejar un conjunto de metodologías muy amplio, y ser muy abierto, para cuando consigamos "cajitas cerradas" como esas, ver cómo lo hacemos con nuestra imaginación y nuestra experiencia.

Bien, continuamos con las características de los enfoques metodológicos que demanda la Administración Pública. Decíamos que demandan los que estén orientados a amplias consultas y promoción de las mismas, los que conlleven metodologías propuestas por la misma administración pública, y los que proporcionen agenda de acciones y validación. Vamos con esta última parte: a la Administración Pública también le interesa, como les decía, ese compromiso de los diversos actores, que es una especie de validación sociopolítica de su propuesta. Y también les interesa contar con sistemas de indicadores y de evaluación de las acciones que contienen el plan que se presenta.

Proseguimos ahora con el punto cuatro de esta plática. ¿Qué tanta utilidad le otorgan -tanto la Iniciativa Privada y la Administración Publica- a estas consultorías en prospectiva-estratégica?. En el caso de la Iniciativa Privada, de nueva cuenta, le interesa pues el porvenir de su negocio, el futuro de la cadena productiva, el de su cámara de representación empresarial. Entonces ellos tienden a sacar muchísimo provecho de esa inversión que realizan en el estudio prospectivo, por eso son muy exigentes. La consultoría en prospectiva, desde el punto de vista de una erogación para una empresa, no es algo que cueste cinco pesos, entonces también esperan resultados. Finalmente, son actores que sí tienden a inquietarse por el porvenir de sus negocios. Por ello, esperan sacar provecho de la inversión realizada; además emplean los resultados, al menos, para oportunidades de mercado de mediano plazo. Y asimismo los utilizan para realizar seguimiento de riesgos y de tendencias. Esto último lo usan mucho aquí en el país, como les decía al principio, para los procesos de cabildeos. También, dependiendo de quién sea el que esté más al frente de esa empresa o de esa cámara, les interesaría ganar adeptos dentro de la empresa, para subir de escalafón o incrementar su capital político dentro del gremio de las cámaras empresariales.

En el caso de la Administración Pública son actores inquietos por "su porvenir", que no necesariamente es el porvenir de la institución o del sector, o del país. Por ello, esperan sacar provecho político y/o personal de la inversión pública realizada; también se emplean estos estudios para incrementar el capital político de quien esté al frente del gobierno o la institución; y se usan como base de los programas 
de gobierno; programas que están obligados a presentar ante la ciudadanía de la entidad. Mire, les interesa mucho su porvenir, su capital político. Entonces ellos se preguntarán: "cómo saco provecho político y personal a estos asuntos". Recuerdo hace unos años, hace aproximadamente unos diez u once años se creó una comisión especial de prospectiva en la Cámara de Diputados. Al diputado que propuso la creación de dicha comisión, no le dieron la presidencia de esa comisión, pero él se interesó en el tema. En esa época yo trabajaba en Consultores Internacionales, y este despacho se encargó de una buena parte de la formación en prospectiva de esos diputados. Y ese señor, aquel diputado que no llegó a la presidencia de la comisión, hoy, once años después, diríamos que es un especialista en prospectiva. Él supo mirar a lo lejos, no se limitó a la coyuntura como muchos funcionarios, además aún cuenta con capital político. En síntesis, la utilidad de la prospectiva en la Administración Pública está condicionada por sus funcionarios de turno.

Vamos ahora con el punto cinco de la plática, el penúltimo de esta conversación. ¿Qué más pueden comprar en términos de visualizar futuros? Miren, yo no vivo de hacer solo prospectiva. Hago mucha prospectiva, he hecho mucha prospectiva, no sé cuántos proyectos en mi vida, pero que vivo específicamente de hacer sólo consultoría en prospectiva, pues no. Sí trabajo con muchos proyectos relacionados con el futuro, con estudios de futuro, pero no necesariamente todos son de prospectiva. Trabajar el largo plazo, tanto para la iniciativa privada como para los gobiernos, no es tarea fácil. Muchas de estas empresas o del gobierno, más que estar pensando y planeando qué hacer en los próximos veinte años, están pensando qué vamos a hacer en el resto del año, en las próximas cinco horas. No obstante, se puede sembrar el interés por los futuros, por explorarlos. Es un poco lo que nosotros hacemos en consultoría, promovemos la inteligencia competitiva o la inteligencia estratégica para observar riesgos o tendencias que puedan influir en el futuro del sector, del territorio, de la empresa. La Iniciativa Privada, entonces, demanda y por tanto compra: a) sistemas de inteligencia estratégica y b) planeación participativa. Veamos cada caso.

El sistema de inteligencia estratégica o inteligencia competitiva, permite explorar aspectos relevantes del entorno y proporciona información estratégica y oportuna expresada en novedosos sistemas de indicadores, presentados con el apoyo de tecnologías de información. Esto al empresario le permite analizar su cartera de productos y servicios más al corto plazo, más para los próximos cuatro, cinco años, observar los riesgos y aprovechar oportunidades. Y hablo siempre de corto plazo en los términos que empleamos en prospectiva, es un corto plazo muy europeo. Eso sí, este tipo de servicios de inteligencia competitiva son más factibles 
para una gran empresa, entonces esto es muy importante que lo tengan en consideración. También se puede ofrecer planeación estratégica y participativa, son planeaciones estratégicas empresariales, con su análisis de entorno y participación de actores clave. Puede ser cualquier proyecto que requiera un análisis de futuro dentro de la misma organización; incluyendo el desarrollo organizacional, pero donde usemos la planeación participativa.

En el caso de la Administración Pública, ¿Qué más pueden comprar en términos de visualizar futuros? Pueden demandar: a) sistemas de monitoreo y evaluación del programa de gobierno, para detectar la coherencia de la acción pública y la generación de valor público: b) observatorios sectoriales: de las áreas de interés; c) modelos de simulación: sectoriales con tendencias y/o pronósticos y d) coloquios, reflexiones sobre los futuros. Los sistemas de monitoreo y evaluación de programas de gobierno generalmente les interesa, aunque sea un futuro más corto, pero es futuro. En el caso de los observatorios sectoriales, han crecido mucho en el país; especialmente a raíz del significativo presupuesto y la Iniciativa Mérida para combatir los problemas que genera el narcotráfico. Por ello han crecido mucho los observatorios ciudadanos, los observatorios de seguridad ciudadana, los observatorios de desarrollo social. En el caso de los modelos de simulación, se puedan hacer ad hoc, a la medida de las solicitudes de determinadas Secretarías. Asimismo todo lo tenga que ver con organización de eventos, vamos a reflexionar sobre el futuro de la educación, vamos a reflexionar sobre el futuro de la alimentación, vamos a reflexionar sobre el futuro del desarrollo energético del país... todo este tipo de reflexiones les interesa a la Administración Pública.

Pasemos ahora al último punto de nuestra plática. ¿Quiénes venden prospectiva en el país? Para la Iniciativa Privada son los despachos internacionales, esos mismos que están en Colombia, que están en Chile, que están en Perú, no tanto en algunos países europeos. Pero sí están aquí. Son despachos internacionales que realizan consultorías de negocios y de mercados, prospectiva como tal no lo hacen, pero tienen la capacidad para realizar análisis de futuros. Son esos despachos internacionales muy bien plantados, que les dicen a los empresarios "yo te lo hago", no le tienen miedo a nada en consultoría. Aunque, reitero, en muchos casos no realizan prospectiva sino, por ejemplo, efectúan rigurosas investigaciones de mercados para detectar oportunidades. También están los despachos internacionales que realizan consultoría en management, especialmente para abordar los proyectos de prospectiva institucional, aunque finalmente no efectúan prospectiva propiamente dicha sino planeación estratégica y/o reingeniería. También en el país ofrecen prospectiva los despachos nacionales y consultores independientes, en este 
renglón me incluyo, son especialistas en estudios de futuro, prospectiva y asuntos semejantes, que hasta donde tengo entendido son muy, muy pocos; y también están los especialistas en competitividad empresarial, que aunque no realicen prospectiva, sí se enfocan a la inteligencia competitiva como un asunto clave de futuros. En general, me parece que en el país se está abriendo un campo para los prospectivistas, especialmente para los que realizan consultoría de negocios y de mercados y que quieran orientarse también a los asuntos de estudios de futuro.

En menor medida, otro oferente para la Iniciativa Privada son las instituciones de educación superior, vale decir, los centros de investigación y/o grupo de académicos, especialmente de instituciones de educación superior privadas, aunque no necesariamente sean especialistas en prospectiva sino en el área temática y con la capacidad para abordar su área desde posiciones de prognosis. A las instituciones públicas de educación superior no se les ha facilitado los nexos con las empresas o las cámaras, les ha sido un poco más difícil convertirse en proveedores de servicios de la Iniciativa Privada.

En el caso de la Administración Pública, también uno de sus principales proveedores de estos servicios son los despachos internacionales, tanto los que realizan consultoría de negocios como management, en especial para prospectiva sectorial y procesos de planeación estratégica en el marco del periodo de la administración pública del caso. También figuran muy bien las instituciones públicas de educación superior y más aún existen cambios en la legislación actual de las compras de gobierno que favorecen la participación de las instituciones de educación superior... aunque no sean especialistas en prospectiva o no cuenten con experiencia práctica en estos asuntos. También a las instituciones de educación superior pública o centro de investigación se les convidan para que hagan precisamente esas metodologías de las que platicamos hace un rato. Otro oferente de la Administración Pública son los despachos nacionales, especialmente de reciente creación y conformados por personas afines a la administración pública del caso, y los despachos de consultoría política, que trabajan más bien perspectivas políticas y/o electorales, y están lejos de la prospectiva-estratégica. En todos los casos, también acá existe una ventana de oportunidades para los especialistas en prospectiva de las instituciones de educación superior o los que quieran incorporarse a estos despachos para respaldarlos con sus capacidades técnicas.

Bien, muchísimas gracias por escucharme. Esto es un poco, en resumen, lo que he querido compartirles hoy, de esta experiencia que tengo analizando y viviendo la consultoría en el país. Si hay tiempo para consideraciones y preguntas, bienvenidas. 


\section{QUIÉNES SON LOS AUTORES Y ACTORES}

Alonso Concheiro, Antonio. Tuvo el grado de Ingeniero Mecánico Eléctrico en la UNAM y en 1975 obtuvo el de Doctor en Ingeniería de Control del Imperial College of Science and Technology, Londres, Inglaterra. Entre 1984 y 1994 fue investigador y director de la Fundación Javier Barros Sierra AC y de su Centro de Estudios Prospectivos AC. Ha sido miembro, miembro fundador y miembro de la mesa directiva de diversas asociaciones científicas y tecnológicas; entre otros fue miembro del Consejo Ejecutivo de la World Futures Studies Federation (París, Francia) y del Institute for 21st Century Studies (Washington DC, Estados Unidos). Actualmente es académico de número de la Academia Mexicana de Ingeniería, presidente del Consejo Directivo de la Fundación Javier Barros Sierra AC y miembro del Consejo Directivo del Capítulo México de la World Future Society, y presidente del Capítulo Iberoamericano de la World Futures Studies Federation. Ha dedicado desde la década de los setentas su vida profesional a los estudios de prospectiva y planeación estratégica. Desde 1995 es socio consultor de Analítica Consultores.

Aguilar Cuevas, Edmundo. Ingeniero Mecánico Electricista, UnAm, 1982. Ingeniero de Sistemas, IBM de México, 1978-1980. Maestría en Ciencias (M.S.) Administración Internacional Agro-Alimentaria, IGIA (Francia) Institut de Gestion Internationale Agro-Alimentaire, 1984. Maestría en Administración (M.B.A.), ESSEC (Francia) Ecole Superieure des Sciences Economiques et Commerciales, 1984. Diplomado en Comercio Exterior, ITAM, 1989. Maestría en Administración, Especialidad Sistemas de Salud, UNAM, 2006. Aceptado por el jurado del Conservatorio 
Nacional de Artes y Oficios de Paris, para iniciar estudios de doctorado 2015-2017. Doctorado en Ciencias de la Administración especialidad en Prospectiva y Estrategia de las Organizaciones, Chaire de Prospective Industrielle. Experiencia: De 1977 a 1997 trabajo en el sistema financiero nacional e internacional, México, Paris, Londres y Chicago en las áreas de banca de inversión, financiamientos internacionales e ingeniería financiera. De 1997 a la fecha se ha especializado en el desarrollo de proyectos relacionados a la industria agroalimentaria, horticultura ornamental, medio ambiente, energía y sistemas de salud. Las áreas de especialidad de su empresa de consultoría son: prospectiva, estrategia, reestructuras corporativas, finanzas, ingeniería financiera, comercialización nacional y de exportación.

Arroyo Margarita. Licenciada en Administración por la Universidad Autónoma Metropolitana (México). Obtuvo el Diploma de Estudios Avanzados en Ciencia Política y Administración por la Universitat Oberta de Catalunya y es doctoranda del Programa "Sociedad de la Información y el Conocimiento" de la misma universidad. Ha publicado diversos artículos sobre comunicación, prospectiva y educación.

Baena Paz, Guillermina. Licenciada en Ciencias de la Información, Maestra en Administración Pública y Doctora en Estudios Latinoamericanos. Miembro de diversas asociaciones profesionales como la World Future Society, de la Executive Board de la World Futures Studies Federation y Vicepresidenta para la región iberoamericana de la misma WFSF.

Desde 1968 es profesora de la UNAM y diversas instituciones educativas. Ha publicado más de cuarenta libros impresos y electrónicos, participó en 25 libros colectivos. Coordina el Seminario Permanente de Estudios Prospectivos, (UNAM). Desde 2003. Ha sido conferencista nacional e internacional invitada a participar en diversos eventos sobre prospectiva en España, Colombia, Perú, Venezuela, Costa Rica, EEUU, Ecuador, Brasil, Rumania, Guatemala y para el ILPES CEPAL. Es profesora internacional para la Universidad del Externado en Colombia. Ha asesorado a funcionarios de Colombia, de Costa Rica, del D.F y de los estados de México, Morelos y Chiapas. Dirige la Serie Working Papers, la serie Papers de prospectiva y la serie Cuadernos de Pensamiento Prospectivo Iberoamericano. También es directora de la Revista del Instituto de Administración Pública del Estado de México (IAPEM). 
Carvajal, Moraima. Docente y consultor experto en métodos de prospectivaestratégica, sistemas de inteligencia estratégica y apoyo técnico al cabildeo. Más de 20 años de experiencia profesional en estas áreas. Ponente en eventos nacionales e internacionales. Ha participado en un sinfín de proyectos de estudios de futuro, prospectiva de cadenas productivas, prospectiva territorial, prospectiva política y sectorial. Docente invitado del Programa de Gobernabilidad y Gerencia Política para América Latina, de George Washington University; de la Maestría de Seguridad Nacional del Colegio de la Defensa y de la Facultad de Ciencias Políticas y Sociales de la Universidad Nacional Autónoma de México. Formación en Prospectiva-Estratégica en Instituto Europeo de Prospectiva y Estrategia (Zarautz, España).Coach certificada y afiliada a International Association of Coaching.

Cerrvera Medel, Manuel. Director General de la Consultoría en Prospectiva Inteligenzza, S.A. de C.V. Especialista en gestión estratégica y análisis prospectivo. Consultor en Análisis Político y Económico. Miembro de la Red latinoamericana de expertos del Programa de Análisis Político y Escenarios Prospectivos (PAPEP) del PNUD-ONU. Presidente del Comité Nacional de Capacitación y Adiestramiento de la Industria Siderúrgica y miembro de la Unidad de Apoyo Técnico a la Capacitación de la Cámara Nacional del Hierro y del Acero; editor de la revista Éxito en Gerencia, fue Rector del Instituto Superior de Estudios Empresariales. Entre las intervenciones que ha dirigido, por citar algunos trabajos, se encuentran: Desarrollo de la Cuenca Lerma-Chapala, Desarrollo de la Reserva de la Biosfera de la Sierra Gorda de Querétaro, Visión de Gran Futuro de San Miguel de Allende, Gto., Visión de Gran futuro del Municipio de Querétaro, Escenarios de Desarrollo Urbano y Movilidad del Área Metropolitana de Panamá al 2040. Programas de control biológico Moscafrut y Moscamed, Weyerhauser, Pastelería El Globo y Galletas Gabi, Instituto Interamericano de Cooperación para la Agricultura; creación del Centro de Investigación Dialógica y Transdisciplinaria (CIDYT), Programas estratégicos del Centro de Investigaciones y Estudios Superiores en Antropología Social (CIESAS) y el Instituto Mora. Prospectiva tecnológica: en sistemas de salud, empaques plásticos, industria de autopartes, industria aeroespacial. Escenarios prospectivos de Aforo. Conferencista en temas de Prospectiva. Colabora con las Facultades de Ciencias Políticas y de Contaduría y Administración de la UNAM en la divulgación y formación en Prospectiva. Entre sus publicaciones tiene: Sistema de Inteligencia y Dirección: la prospectiva como herramienta directiva, Convenio Andrés Bello, el working paper FODA: un enfoque prospectivo, publicado por la UNAM. Estudio de Gran Visión de San Miguel de Allende, Guanajuato, coautor. Participación como expositor en Diplomados. 
DidRiKsson Takayanagi, AXel. Investigador Titular "C" de Tiempo Completo, adscrito al Instituto de Investigaciones sobre la Universidad y la Educación (IISUE), de la UnAm. Ex Secretario de Educación Pública del Distrito Federal. Creador de un modelo de universidades en América Latina. Coordinador entre el Instituto Internacional Para La Educación Superior en América Latina y el Caribe y la Cátedra UNESCO de Integración Regional y Universidad. Tiene ascendencia sueca y japonesa. Ha escrito múltiples libros y artículos sobre educación. Fue fundador de la Red Latinoamericana de Prospectiva y fundador de la Escuela Virtual de Prospectiva Latinomaericana (ELAP) la cual empezó a funcionar en el 2014.

MÉndez Morales, SiLvestre. Es Maestro normalista, Licenciado en economía por la Facultad de Economía de la UNAM y Maestro en Administración con mención honorífica, cursó el diplomado universitario de Formación de investigadores. Docente por más de 47 años, actualmente es el jefe de la División de Investigación de la Facultad de Contaduría y Administración de la UNAM, es profesor de licenciatura y posgrado en el área de Economía en la Facultad de Contaduría y Administración. Es miembro del seminario permanente de Prospectiva de la Facultad de Ciencias Políticas y Sociales desde hace más de cinco años, participa en los seminarios de Complejidad, Argumentación y Sustentabilidad de la FCA, Conferencista en congresos nacionales e internacionales, cuenta con más de 200 tesis dirigidas a nivel licenciatura, especialización y maestría y es miembro de la comisión dictaminadora PRIDE de la Escuela Nacional de Estudios Superiores de la UNAM en León. Entre sus más recientes publicaciones destacan: Fundamentos de economía para la sociedad del conocimiento (6 ${ }^{\mathrm{a}}$. edición); La economía en la empresa en la sociedad del conocimiento; Problemas Económicos de México y Sustentabilidad ( $7^{\text {a }}$. edición); De las ideas al libro, Reforma a la Ley Federal del trabajo 2012 (2ª edición). Colaborador de las obras: El enfoque de la complejidad. Diversas perspectivas y Espacios anticipatorios y prospectivos. Escenarios al 2050.

Miklos, Tomas. Ingeniero Químico (Universidad Nacional Autónoma de México); Doctor en Ciencias (Universidad de la Sorbona); Estudios de Psicología, Análisis Transaccional, Administración y Psicoanálisis. Ha publicado: "Planeación Prospectiva; una estrategia para el diseño del futuro"; "Planeación Interactiva; nueva estrategia para el logro empresarial"; "Las Decisiones Políticas; de la Planeación a la Acción", (Coordinador y Coautor); "Diagnóstico y Prospectiva de la Educación Superior en México" (Coordinador y Coautor); artículos sobre desarrollo personal y planeación en revistas especializadas 
Millán Bojalit, Julio. Fundó el capítulo mexicano de World Future Society, el cual preside actualmente. Esta asociación es reconocida como la más importante en el estudio del futuro a nivel internacional. Ha sido miembro de los Consejos de Administración de Nike México, Corporación GEO, Sears Roebuck de México, Banco Comermex y Olivetti Mexicana entre otras. Es presidente de las empresas que conforman el grupo Coraza Corporación Azteca, entre las que destacan Consultores Internacionales, (especializada en la organización de negocios internacionales a gran escala en los sectores de transportes, energía y telecomunicaciones), con negocios como Inteligencia Competitiva, Planeación Prospectiva y Centro de Desarrollo Pyme y Corporación Inmobiliaria IPSA. Participa asiduamente en varios medios de comunicación como Reforma, El Universal, Expansión y Radio Red, entre otros. Es autor del libro México 2030: nuevo siglo, nuevo país. Ha organizado eventos internacionales sobre prospectiva.

Montero Olivares, Sergio. Licenciado en Ciencias de la Comunicación, Maestro en Administración Pública, Doctor en Administración Pública. Miembro de Asociación Mexicana de Investigadores de la Comunicación (AMIC) y de la Asociación Latinoamericana de Investigadores de la Comunicación (ALAIC), miembro de la World Futures Studies Federation; Miembro del Instituto Nacional de Administración Pública y miembro asociado del Instituto de Administración Pública del Estado de México. Coautor y autor de varios libros. Ha ejercido su carrera en diversos cargos directivos en el sector público y privado en el campo de la Comunicación, las Relaciones Públicas y la Publicidad. Director de las dos licenciaturas de Comunicación y Relaciones Públicas del país (tanto en la Universidad Latinoamericana y en la Universidad Americana de Acapulco). Actualmente se desempeña como consultor en prospectiva, relaciones públicas, publicidad comunicación organizacional y mercadotecnia política, asesoría personalizada, imparte cursos especiales en partidos políticos y empresas privadas Es asesor del Seminario de estudios Prospectivos en la UNAM, especializándose en Prospectiva, globalización y sociedades del futuro y es profesor universitario en diversas instituciones educativas. Ha elaborado varios estudios prospectivos para instituciones públicas Publicó el libro Una visión prospectiva de la Administración Pública para la sociedad mundial al 2050, editado por el Instituto de Administración Pública del Estado de México.

SABAG, AdiP. El Dr. Adip Sabag, es reconocido como el "Padre de la Prospectiva en América Latina”, actualmente es Director General del Instituto Superior de Estudios Prospectivos ISEP, del Espacio Prospectivo, del Museo del Futuro Futuronium 
y del Planetario Astroseum en San Lucas Cuauhtelulpan del estado de Tlaxcala, México. También es fundador del Instituto Nacional de Opinión Pública y preside el Instituto Internacional de Prospectiva, A.C. Es autor, coautor y compilador de diferentes obras entre las que figuran: El Mexicano Opina, Prólogo de Francisco Huerta e ilustraciones de Pedro Sol (Laboratorio de Opinión Pública) ¿Qué es la Prospectiva? (EDUVEM); Apuntes de Prospectiva (isep); Creatividad (EDUVEM); ¿Laguna Verde Nuclear? ¡No gracias! (Claves Latinoamericanas); Hipnosis: Aplicaciones en la Escuela (Olmeca, impresiones Finas); Teoría de Catástrofes (EDUVEM); Teoría del (Des) orden (EDUVEM); Cómo crear su propia empresa (UNAM-UVM-UAM). Es Doctor en Prospectiva por la Universidad de París. Maestro en Sociología por la Universidad de Lovaina, Bélgica. Obtuvo Licenciatura en Medio Ambiente en la Universidad de Bruselas y el título de Psicólogo en la Universidad Nacional Autónoma de México. Ha realizado más de dos mil quinientas encuestas que se han publicado en los diarios más importantes del país como Excélsior, Universal y el Financiero.

Serbolov, Yuri. Director de la revista La Carpeta Púrpura desde hace 27 años. Profesor de la Universidad Nacional Autónoma de México (UNAM) en la cátedra de Prospección y Megatendencias. Profesor de la maestría de la Escuela de Periodismo Carlos Septien. Miembro de la World Futures Studies Federation (WFSF). Licenciado en Economía por la UNAM. Especialidad en Educación por la Confederation College of Canadá y la Escuela Bancaria y Comercial (EBC) de México. Socio consultor de Certus. Director General SEPPI, S.A. de C.V. Premio Nacional de Periodismo en 1998 en la categoría de análisis prospectivo. Presidente del Consejo del Centro de Estudios Prospectivos del IAPEM, 19 marzo 2010 a 2011. Curso de Actualización docente y Didáctica Compleja por la UNAM, 2011.

SORIA Villegas, Francisco. Ingeniero Mecánico Electricista y Maestro en Ingeniería por la UNAM, profesor Titular de Tiempo Completo en Facultad de Ingeniería de la UNAM. En actividades históricas profesionales la coordinación para la creación de la "Especialización en Mantenimiento a Equipo de Instrumentación y Control" modalidad a distancia por la Facultad de Ingeniería de la UNAM, con cuatro libros de texto y sus contenidos en línea (2005). En ambientes colaborativos Consejero Técnico por la Carrera de Ingeniería Mecatrónica en FI-UNAM (2003-2010); Consejero Asesor del SUAyED-UnAm (2009-2011) por el CAACFMI-UNAM. Actualmente integrante del Seminario Global de Formación Prospectiva de la UNAM, con interés en prospectiva de las convergencias tecnológicas y sociales. 
Charlas Prospectivas. Con sus autores y actores. Contribución a la historia de la Prospectiva en México. En su composición se usó el tipo ITC BERKELEY STD de 11/13,2 puntos. Diseño y formación: Marco Antonio Pérez Landaverde. Término de la edición en CD: 30 de junio, 2016. 
